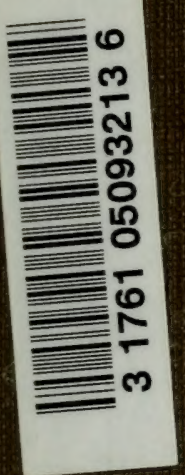




2

THE BUTTER INDUSTRY IN THE UNITED STATES

xye e 

STUDIES IN HISTORY, ECONOMICS AND PUBLIC LAW

EDITED BY THE FACULTY OF POLITICAL SCIENCE

OF COLUMBIA UNIVERSITY

Volume LXIX]

[Number 2

Whole Number 165 )

\section{THE BUTTER INDUSTRY IN THE UNITED STATES}

An Economic Study of Butter and Oleomargarine

BY

EDWARD WIEST, Ph.D.

Instructor in Economics, University of Vermont

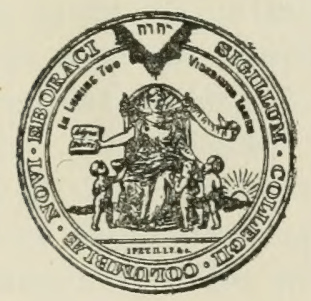

New Work

THE COLUMBIA UNIVERSITY PRESS

LONGMANS, GREEN \& CO., AGENTS

LONDON: P. S. KING \& SON, LTT.

1916 
Copyright, IgI6

BY

EDWARD WIEST 


\section{PREFACE}

THE dairy industry has not yet received the attention from the student of economics that it deserves. The wealth that flows from this industry in the form of butter, cheese, and milk, to say nothing of by-products, make it one of our principal agricultural interests.

The conversion of milk into butter and cheese bas caused manufacturing industries to grow up which present important economic problems. The butter industry, especially, has a history deserving a much more prominent place in our text-books on economic history than has thus far been given to it. The market organization presents problems that are of current interest. Among these may be mentioned the attempt to control prices by methods peculiar to the butter industry. The subject leads the investigator into the complex problem of the relation of the production of butter to the production of other food products. Considerable attention has been given to this phase in the chapter on the geographical distribution of butter production and in the chapters dealing with oleomargarine. The study shows that the ambitious youth may find an industrial environment in the rural districts quite as interesting and stimulating as that of urban centers. A great deal of dairy legislation has been enacted for the protection of the public health and for the prevention of fraud. An analysis of the conditions leading up to this legislation, however, reveals the fact that the dominating force behind the movement was not ethical but economic. 
In connection with this study the author wishes to acknowledge his indebtedness to Prof. Henry R. Seager for making valuable suggestions and criticisms, and to Prof. Edwin R. A. Seligman for his kindly encouragement. Acknowledgment is also due to Mr. F. G. Urner, Vice-President of the Urner-Barry Company, New York City, for assistance on matters pertaining to the market. Finally the author wishes to express his gratitude to his wife for the assistance she rendered in preparing the manuscript for the printer and for her general sympathetic support.

EDWARd WIEST.

Burlington, Vermont, November 30, 1915. 


\title{
CONTENTS
}

\author{
CHAPTER I \\ The Manufacture of Butter.
}

The domestic system of manufacture . $\cdots \cdot \cdots \cdot \cdots$

The factory system before the introduction of the separator... I7

The evolution of the cream separator ........... 23

The Babcock tester . . . . . . . . . . . . 25

The introduction of the hand separator. ........ 28

Recent changes in methods of production ......... 30

The growth of the factory system ............. 38

CHAPTER II

Organization for the Production of Butter.

The cow-testing association ............ 44

The breeding association.............. 52

Coöperative buying associations .......... 57

Business organization of the creamery . . . . . . . 58

\section{CHAPTER III}

Geographic Distribution of Butter-Producing Areas

Historic changes. .............. 77

Soil and topography .................... 82

Climatic influences ..................... 88

Influence of cities ............... 9I

Social influences ................ . . . . 99

\section{CHAPTER IV}

Organization for Dairy Education.

General statement. . . . . . . . . . . . 102

The land-grant colleges .............. 103

The experiment stations ............... 105

Coördination of land-grant colleges and experiment stations. . . . 107

Courses in dairying . . . . . . . . . . . . . . 108

Machinery for the popularization of science ........ I I0

Dairy instruction in secondary agricultural schools . . . . . . II5

23I] 7 
Grading and Judging Butter.

Standardization in general ........... II7

Reasons for the establishment of butter grades ......... II8

Benefits of grading. . . . . . . . . . . . I2I

Classifications and grades ............. I . . 22

The evolution of classifications. . . . . . . . . . . . I24

The development of grades. . . . . . . . . . . . I33

Philosophy of grading. . . . . . . . . . . I . I35

The uses of grading ................. 137

CHAPTER VI

History and Development of the Organization of the Butter Market.

Early conditions. . . . . . . . . . . . I39

Direct consignment to commission merchants ... . . . . . I42

The establishment of producers' exchanges .......... I43

The establishment of middlemen's exchanges . . . . . . . I46

Causes for the organization of exchanges. . . . . . . . I48

The contract system .............. . . . . . I30

Cold storage ................... I5I

CHAPTER VII

The Present Organization of the Butter Market.

The distributing centers ............. . . I53

The dealers . . . . . . . . . . . . . . . . I59

The organized markets .................. I63

Cold storage . . . . . . . . . . . . . . I77

CHAPTER VIII

Butter Prices.

Influence of a producers' exchange upon prices . . . . . . . I8I

Wholesale and retail prices compared .......... 186

The division of the consumer's price ......... . . 189

Seasonal price fluctuations ............. 192

Movement of the annual average price . . . . . . . 197

CHAPTER IX

Adulteration and Oleomargarine.

Adulteration of foods .................. 210

History of oleomargarine................ 214 
Manufacture of oleomargarine ............ 219

Wholesomeness of oleomargarine ........... . 226

Renovated and adulterated butter . . . . . . . . . . 229

The movement for oleomargarine legislation ........ 234

\section{CHAPTER X}

The Oleomargarine Law and its Development.

Summary of development . . . . . . . . . . . . 24I

Restrictive and prohibitory laws of Pennsylvania . . . . . . . . 244

The case of Powell $v$. Pennsylvania . . . . . . . . . 245

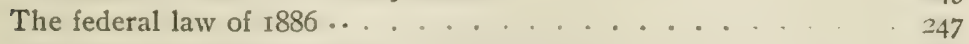

The case of Schollenberger $v$. Pennsylvania . . . . . 250

Re-enactment of the restrictive principle in Pennsylvania . . . . 254

The federal act of May 9, I902 . . . . . . . . 256

The effect of oleomargarine legislation ....... . . . 257

Revision of the law necessary............ 263 



\section{CHAPTER I}

The Manufacture of Butter

\section{THE DOMESTIC SYSTEM OF MANUFACTURE}

Butter-Making on the farm is the domestic system of manufacture in the butter industry, and is to be contrasted with the factory system of production. In the United States the first butter factory was put into operation in I86I; until then the making of butter remained a domestic industry exclusively. The first factories were known as butter factories, but they soon came to be known as creameries, and this designation has now become well established. Creameries sprung into prominence in the 70's, and since then there has been remarkable development in the butter industry. In spite of this growth, however, the domestic system remains, and there is still more butter made on the farm than in the factory, as may be seen by referring to Table no. I.

In this country the manufacture of cheese has changed almost entirely from the domestic system to the factory system. The manufacture of butter, however, is still divided between the farm and the factory in the proportion of about three-fifths for the farm and two-fifths for the factory. In spite of the fact that more than half of the butter is still made on the farm, the domestic system as compared with the factory system shows a gradual decline during the last twenty-five years, and it may be expected that the transfer of butter-making from the farm to the factory will continue with the improvement of trans235] 
portation facilities until only a small fraction will continue under the domestic system. The manufacture of butter remained exclusively a domestic industry long after other industries had felt the effects of the Industrial Revolution. As is well known, the Industrial Revolution was proceeding most actively from $I 760$ to 1830 , the time during which the great inventions of spinning and weaving machinery, the steam engine, the lock canal, the railroad, etc., truly revolutionized the methods of manufacture in many

\section{TABLE I}

The Amount of Butter Produced in the United States on the Farm AND IN THE FACTORY IN I899 AND 1909

\begin{tabular}{|c|c|c|c|c|}
\hline \multirow{2}{*}{ System } & \multirow{2}{*}{1909} & \multirow{2}{*}{ I 899} & \multicolumn{2}{|c|}{ Per cent of Total } \\
\hline & & & 1909 & I 899 \\
\hline $\begin{array}{l}\text { Butter............................ } \\
\text { Factory product..... }\end{array}$ & $\begin{array}{c}\text { Pounds } \\
\text { 1,61 } 9,4 \mathbf{1} 5,263 \\
624,764,653 \\
994,650,610\end{array}$ & $\begin{array}{c}\text { Pounds } \\
1,491,752,602 \\
420,126,546 \\
1,071,626,056\end{array}$ & $\begin{array}{l}100 \\
38.6 \\
61.4\end{array}$ & $\begin{array}{l}100 \\
28.2 \\
71.8\end{array}$ \\
\hline 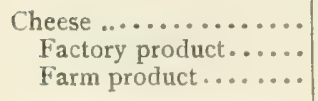 & $\begin{array}{r}320,532,181 \\
311,126,317 \\
9,405,864\end{array}$ & $\begin{array}{r}298,344,642 \\
281,972,324 \\
16,372,318\end{array}$ & $\begin{array}{r}100 \\
97.1 \\
2.9\end{array}$ & $\begin{array}{l}\text { roo } \\
94 \cdot 5 \\
5 \cdot 5\end{array}$ \\
\hline
\end{tabular}

(From the rath Census, vol, 9.)

industries. During this time some industries were very rapidly transferred from the home to the factory. The most rapid change came in the clothing industry. During this marvelous industrial development the enterpriser and inventor paid but little attention to the dairy industry. Many new kinds of churns were invented, but these could not change fundamentally the character of the industry. This was because there were inherent difficulties in the industry that checked its development. The preservation of 
butter before the days of cold storage was a problem, and as butter is a very perishable product, it was desirable to send it to market as it was made. The application of the factory system to the manufacture of butter was therefore delayed until transportation and cold-storage facilities were developed. It will be seen, also, below that the amount of capital required in the butter factory as compared with the amount needed at home is another important check against rapidly transferring butter-making from the farm to the factory.

The equipment for making butter on the farm before the introduction of the hand separator has always been very simple, and in the early days of the country has often been very crude. The most primitive method used in churning butter is the agitation of milk or cream in skins. ${ }^{1}$ This method is known to have been used in ancient times. As late as 1887 in Argentine, S. A., in the vicinity of Buenos Ayres, the same method was used. ${ }^{2}$ Skins containing the milk were tied on the back of a horse and taken by the rider to the city. By the time he arrived at his customer's door the butter was churned. In England in the twelfth century a wooden dash churn was used. In America from the colonial days to the present time a great diversity of churns have been in use. Various types of dash churns, barrel churns, and box churns were used. The butter churn received a great deal of the inventor's attention. Henry E. Alvord writes in the Agricultural Ycarbook of I889 that a search of the United States Patent Office records reveals the fact that patents were issued providing

${ }^{1}$ For an exllaustive treatment of equipment in the dairy industry, see Bailey's Encyclopedia of American Agriculture, vol. iii, pp. 198-207.

${ }^{2}$ From a letter by Baylis W. Hanna, of the United States Legation, dated Buenos Ayres, Nov. I1, 1887, reprinted in the Fourth Annual Report of the New York State Dairy Commissioner, p. I64. 
a new churn every ten or twelve days for more than seventy years.

The churning of butter on the farm is usually done by hand. Frequently, however, other power is used, especially water power. In some sections of the country it has been customary to hitch a dog, a sheep, a heifer, or a horse to a tread-wheel or other device to furnish power for churning. ${ }^{1}$

Before the invention of the separator, cream was, of course, raised exclusively by gravity. When this method is used the milk is placed in vessels and left undisturbed for several days. During this time the cream or fat content rises to the surface. The fat of the milk rises because it is considerably lighter than the water content. On farms especially favored with a spring or a little stream of fresh and pure water in close proximity to the farmhouse, the dairy products were usually kept in spring houses. States with a topography like Vermont are especially favored with numerous cold springs. The use of the spring-house has, therefore, been quite common in these sections of the country. notably in New England and in some of the Middle - Itlantic states. On farms where the spring-house could not be built, deep cellars were dug. Where the gravity system is still used, milk is placed in the spring-house or cellar, and after all the cream has risen it is skimmed. When a sufficient quantity of cream accumulates it is churned into butter. Where the hand-separator is used all the work connected with the setting of cream is of course eliminated; but if the farmer makes his own butter he still finds use for the spring-house or cellar. Some farmers provide themselves with ice.

During the early part of the nineteenth century many

${ }^{1}$ Vide, X. A. Willard, Practical Dairy Husbandry. 
families had no butter in the winter. Much of the butter consumed during the winter was made in the summer and preserved with brine or salt. The butter was packed in firkins or tubs, and in regions remote from towns was taken to market only once or twice each year. ${ }^{1}$

Up to 1850 there was no science in dairying. " "Everything was done by guess; there was no order, no system, no science in dairy operations." 3 This indictment against the farmer still holds in a great many cases. The unsanitary conditions under which the greater portion of the supply of milk is produced and marketed is a rebuke to society, and demands the earnest and unceasing attention of the scientist, the advocate, the legislator, and the administrator. Marvelous progress has of course been made in science, and dairy products are frequently produced and marketed under almost perfect sanitary conditions and according to rules definitely known to bring certain results. This is usually the case where medical milk commissions diligently perform their duties and also in the making of creamery butter; but on a great many farms, where dairying is not specialized, sanitation is very sadly neglected. Unless one experiments in the chemical laboratory or studies reports dealing with effects of bacteria upon human life, it is somewhat difficult to appreciate the importance of producing and marketing milk in such a way as to exclude putrefactive bacteria and disease germs. The fact that the domestic system of manufacture is decentralized causes dairy butter on the whole as compared with creamery butter to be much poorer in quality. Before the edu-

${ }^{1} \mathrm{H}$. E. Alvord, Agricultural Yearbook for 1899, p. 383.

Ibid.

3 For a treatment of the principles of dairying, see H. E. Van Norman, First Lessons in Dairying; Grotenfelt and Woll, The Principles of Modern Dairy Practice; H. H. Wing, Milk and its Products. 
cational campaign that has been waged during the last thirty years there was much more diversity of quality in farm-made butter than at present. Progress in the quality of dairy butter, however, seems to be indicated by the gradual decline in the yearly amounts of renovated butter produced in the United States. Renovated butter is poor butter collected at country grocery stores, melted at a low temperature, and churned with milk. In 1903 the amount renovated was over $54,000,000$ pounds, and in 1914 , over $32,000,000$ pounds. ${ }^{1}$ A part of this decline, of course, is due to the fact that the domestic is slowly giving way to the factory system. Under the factory system scientific methods are applied and creamery butter must necessarily be of better quality than that of the average dairy product. Good dairy butter is made by some farmers, but comparing dairy butter as a class with creamery butter, the quality is poorer and less regular than that of creamery. As the manufacture of creamery butter therefore increases, more and more good butter will be produced, and this will have the effect of gradually displacing dairy butter.

The labor connected with butter-making on the farm frequently falls to the lot of the women of the household. This was especially true in earlier times. In some sections of the country the women seldom perform any service at the barn or on the fields, but take charge of the milk after it is placed in the cellar or spring-house. In other sections women have frequently been called upon not only to do the milking, but to work in the field. In recent years, however, it has been the tendency everywhere to relieve the women of the more arduous duties of farm work. In many sections the men do all the milking, or at least assist the women. Successful milking machines are on the market

${ }^{1} V i d e$, Reports of the U. S. Internal Revenue Commissioner. 
and are being gradually introduced. These machines, however, need a great deal of care and must be thoroughly sterilized in order to produce pure milk. ${ }^{1}$ This fact, together with the initial cost of the machine, may hinder its rapid introduction. Where the milking machine is used, milking not only loses much of its disagreeable features, but the women are relieved of this part of dairy work. When the milk is separated it is usually done by the men. Steam or other power is sometimes used to run the separator. The skimming of cream and the making of butter on the farm are usually done by the women.

The necessity for the women to coöperate with the men in agricultural work has a very important influence upon the family and social life in the country. Prof. Thomas Nixon Carver says :

The geometrical as well as the social conditions of farm life dictate that there shall be an independent household on every farm. No such set of conditions exists in the city. The unmarried business man and the unmarried business woman may suffer moral and social loss, but they can scarcely be said to be under the slightest disadvantage in a purely business sense. The farmer needs a wife as a part of his equipment because, on the farm, the home is a part of the business and the business a part of the home. Accordingly there are in the country, very few of those old unmarried males who infest the business and professional circles of our cities. The sexes need one another in their work as well as in the life of the country. ${ }^{2}$

THE FACTORY SYSTEM BEFORE THE INTRODUCTION OF THE SEPARATOR

The butter factory, commonly known as the creamery, had its origin in the cheese factory. New York, Pennsyl-

${ }^{1}$ Vide, Bulletin 92, U. S. Department of Agriculture, Bureau of Animal Industry.

2Principles of Rural Economics, p. 23. 
vania, Ohio, and Wisconsin all claim the honor of first organizing the cheese industry on a factory basis.

Mr. A. Picket, who had driven ten cows from Ohio to Rock Lake. Jefferson county, IVisconsin, settled there and began supplying the demand for cheese in I84I. Milwaukee was then a small village, and a territorial road had been laid out from this point to Madison over which people began to travel. Mr. Picket was unable to supply the demand for cheese occasioned by the development of the State's resources, and at the suggestion of his wife entered into a contract with his neighbors to receive their milk and nanufacture cheese. This was probably the first cheese factory in the United States. ${ }^{1}$ The account does not state whether or not the idea of coöperation, or "associated dairying", the name by which the factory system in the dairy industry was first known, spread in the community.

In Ohio in I8.49 a number of cheese establishments purchased the unsalted curd from the farmers. "In 1850 Geo. Hezlep, of Gustavus, Trumbull County, was purchasing the curd from the milk of Iooo cows, paying from $3 \frac{1}{4}$ to $3^{T / 2}$ cents per pound for it and making from IOO to I2O cheeses daily." 2 These enterprises were unsuccessful.

In Pennsylvania ${ }^{3}$ the first cheese factory began work in 18.9 at Mosiertown under the direction of Messrs. Clark and Stebbins. In this case the Ohio plan of buying the curd instead of the milk from the farms was followed. A second factory was built in $185 \mathrm{I}$ and remained "in operation for three years, when this system of factory cheese-

${ }^{1} V$ ide, the Report of the Wisconsin Dairymen's Association for 1878 , pp. 96-7.

${ }^{2}$ Report of the Vermont Dairy Association for 1872, p. 41.

${ }^{3}$ Anmial Report of Transactions of the Pennsylvania State Dairymen's Association for 1876, pp. 3II-I4. 
making came to an end," and was supersecled by the system that had its origin in the state of New York.

In New York the first cheese factory was established by Jesse IVilliams in Oneida county near Rome in IS5I. ${ }^{1}$ The methods developed by Mr. Williams were soon copied in other communities, and the factory system of manufacturing cheese began to spread rapidly in New York, southward into Pennsylvania, and westward into Ohio, and soon became firmly established. The story of the incidents leading up to the organization of Mr. Williams' cheese factory is a very simple one-so simple in fact that the reader is hardly aware that the successive steps culminating in a factory system of cheese manufacture illustrate the philosophy of industrial progress.

Mr. Williams was a skilled cheese-maker and received a higher price for his product than his neighbors received. The demand for his cheese was so great that when one of his sons married and began farming on his own account, the father entered into a contract with the dealer to take the cheese to be made on the two farms at 7 cents a pound, which was considerably higher than the other farmers received. The son, however, did not believe that he could make as good cheese as was required. Arrangements were therefore finally made to have the son deliver the milk at his father's milk-house, where the father manufactured cheese from the milk of both herds. The idea of combining the milk of these two farms led to further combination. The milk of the neighbors was soon added, and in the second year suitable buildings properly equipped were erected.

In this story there are elements of skill, inventive genius, and chance. Mr. Williams was skilled in cheese-making,

${ }^{1}$ Vide, X. A. Willard, Practical Dairy Husbandry, p. 215. 
and he had the genius to see opportunities and to organize his business on entirely new lines. The son's marriage, the father's contract to sell the cheese of the milk of the two herds, coupled with lack of training on the part of the son to make good cheese, were matters of chance. Skill, genius, and chance were here united in such a way as to result in a far-reaching innovation in the dairy industry. ${ }^{1}$ The story is a splendid illustration of how progress is made.

It did not take long for the idea of the cheese-factory system to be applied to butter-making. The first creamery in the United Staes was built by Alanson Slaughter, near Wallkill, Orange county, N. Y., in $186 \mathrm{r}^{2}$

In the evolution of the creamery three stages are noticcable. In the first factory the making of butter and cheese were combined. The cream was raised by gravity, and cheese was made from skimmed milk or from partlyskimmed milk. In the second stage the cream was still raised by gravity, but the creamery or butter factory became a separate and distinct enterprise. Buildings were erected to manufacture butter exclusively. In the third stage the centrifugal separator occasioned a revolution in the butter industry. The principle of raising cream by gravity was superseded by the principle of separation of fat from the skim milk by centrifugal force.

In the early creamery the shallow-setting plan was used. The milk was poured into large shallow vats. It was believed that a larger percentage of the fat would rise by this

${ }^{1}$ While the American factory method in dairying has been copied in Europe and elsewhere, the idea of coöperative dairying cannot be said to have first been tried out in this country. H. E. Alvord says that the Swiss and French in the Jura Mountain region have been making cheese on the coöperative plan in a small way for four centuries. Vide, Census 1900, vol. ix, p. 438.

2 Vide, H. E. Alvord in The Agricultural Yearbook for I899, p. 386; and X. A. Willard, Practical Dairy Husbandry, pp. 237-40. 
method than when the milk was put in deep vessels. This idea was, of course, erroneous. By the deep-setting method a smaller percentage of fat remains in the milk than by the shallow-setting method. ${ }^{1}$ In addition to the loss of fat occasioned by shallow setting, a larger surface of the cream was exposed to the air, and this had a tendency to dry the cream and cause specks to appear in the butter. This method was soon superseded by the deep-setting method. A can having the same diameter at the top and bottom, called the "shot-gun" can, was set in running water and kept at a temperature of from 48 to 56 degrees Fahrenheit. ${ }^{2}$ The system of setting the cream at the factory required a great deal of space, and was therefore inconvenient and expensive. It is not surprising, therefore, that this practice was soon generally discontinued and that the "gathered-cream factories" made their appearance under what was known as the Cooley system or the Fairlamb system. The change came in about $1875^{\circ}$

The Cooley and Fairlamb gathered-cream factories were so called because the cream setting was done on the farm in cans or creamers invented for the purpose by Cooley and Fairlamb. The two cans were somewhat similar. At the bottom of the can a valve made it possible to draw off the skim milk. The amount of cream left could be read on a graduated glass or gauge set in the can. On the Cooley can the spaces on the gauge were nineteen-sixtyfourths of an inch in width and the diameter of the can was eight and a half inches. ${ }^{4}$ The farmer was credited with "spaces" of cream and was paid according to the number

${ }^{1}$ H. E. Van Norman, First Lessons in Dairying, p. 22.

${ }^{2}$ H. E. Alvord, Agricultural Yearbook for 1899, p. 388.

sIbid.

4 Connecticut State Agricultural Experiment Station Report for I893, p. 145 . 
of "spaces" of cream collected by the driver, who was an employee of the factory. The Fairlamb gathered-cream system was popular in Maine and the Western States, notably in the vicinity of Elgin, Ill., and in Iowa, ${ }^{1}$ while in most of New England and the state of New York the Cooley plan found the greatest favor. As late as I893 most of the creameries in Connecticut were operated under the Cooley plan. ${ }^{2}$

The method of paying for cream by the inch or "space" was more refined than paying for milk by the quart or by the pound; but it is crude compared with the method of paying for the percentage of fat found by frequently testing the patron's milk with the Babcock tester which is now in general use. While there was this disadvantage in the Cooley and Fairlamb gathered-cream systems, the new method brought great improvement in the operations at the factory and had a very important influence in extending the factory system. In the western states where the country was sparsely settled the collection of the whole milk was an obstacle in the way of establishing a factory. Cream, however, is less bulky and can be collected over a territory large enough to make a creamery pay. These systems also had the value of establishing a uniform method in handling the milk and setting the cream on the farm. Butter of a more uniform quality could be made. It is seen, therefore, that the "gathered-cream factory" marked a very important advance in the development of the butter industry.

${ }^{1}$ Illinois State Dairy Association, in Transactions of Illinois Department of Agriculture for I881, p. 430.

${ }^{2}$ Connecticut State Agricultural Experiment Station Report for 1893 p. 145 . 
THE EVOLUTION OF THE CREAM SEPARATOR

The principle upon which the mechanical separation of cream is based is the subjection of substances having different specific gravities to centrifugal force. The butter fat in milk has a specific gravity of 0.93 , while that of skim milk is 1.035 . Of these two substances, therefore, fat is considerably lighter than skim milk. It follows, for this reason, that when milk is placed in a vessel made to revolve rapidly that the skim milk, which is the heavier constituent, is drawn to the outer edges of the mass, while the fat is forced toward the center. In order to separate the fat from the skim milk it is only necessary to tap the cream at the center and the skim milk at the periphery of the vessel.

Probably the first mechanical device used to separate cream from milk was constructed in Germany by Prof. C. J. Fuchs in $1859 .{ }^{1}$ The milk was placed in a glass tube which was made to revolve rapidly. Prof. Fuchs' object does not seem to have been to invent a machine that could be used in dairying and that would eliminate cream-setting, but to construct a device by which the richness of the milk could be tested.

In I87o Rev. H. F. Bond, of Massachusetts, separated cream in two glass jars attached to a spindle making 200 revolutions a minute. ${ }^{2}$

At the same time this problem was studied in America experiments were tried in Europe, where the names of Lefeldt, Lentsch, Weston, and De Laval are associated with the development and perfection of the centrifugal

${ }^{1}$ First Annual Report of the New York State Dairy Commissioner, p. 96.

${ }^{2}$ For the successive steps in the evolution of the separator, see Van Norman, First Lessons in Dairying, pp. 86-7; and H. H. Wing, Milk and its Products, p. 112. 
separator. To Europe, therefore, belongs the credit for finally crystallizing into a practical machine an idea which had long been lingering in the minds of inventors.

In 1873 a Dane separated cream by suspending two pails from a stick which was revolved at a speed of 400 revolutions a minute. Machines were also constructed having a series of buckets suspended from arms attached to a vertical shaft. When the shaft revolved rapidly the buckets containing the milk swung out to nearly a horizontal position. The centrifugal force caused the skim milk to be drawn toward the bottom of the pail while the fat was forced to the surface. Whirling, therefore, caused the fat and skim milk to separate into layers, and after the machine was stopped the cream could be skimmed in the same way as it is skimmed when it rises by gravity.

In 1876 there appeared a machine with a vertical drum into which the milk was poured and revolved at a speed of 800 or 900 revolutions. When the process of separation was complete the machine was stopped and the skim milk was siphoned out, after which the cream was removed through a valve at the bottom of the drum. The drum was then filled with milk and the operation was repeated.

Another machine similar to the above showed a slight improvement. The skim milk was removed by opening valves in the periphery of the drum while in motion. To remove the cream, however, is was also necessary to stop the machine.

After the advance that had been made prior to 1877 , it was comparatively easy to take the next step in the evolution of the separator. Accordingly in 1877 and 1878 machines into which the milk could be fed continuously, and which discharged at the same time cream and skim milk, were developed. These machines embodied the basic principles upon which all separators are constructed. 
As a practical machine in the dairy industry, it was not until the following year, in 1879 , that the separator was made commercially successful. During this year the Weston machine was produced in Denmark, and the De Laval in Sweden. In I890 important improvements increasing the efficiency were made on the De Laval separator.

The perfection of the milk separator and its successful introduction is of great importance to the dairy industry. Considerable interest, therefore, attaches to tracing the various steps in its development-especially when it is remembered that all great inventions are evolved by the addition of ideas usually contributed by a number of individuals. The story of the development of the steam engine is not different fundamentally from the story of the evolution of the separator.

THE BABCOCK TESTER

The Babcock tester, perfected in I89o, is a simple device by which the percentage of fat in milk can be tested. The great need for such a test had long been felt. Already in the early stages of the factory system, in 1863 , the cheesemakers were seeking a fair and accurate method of paying for the milk. ${ }^{1}$ Each patron was paid according to quantity and not according to quality. It was charged that adulteration and dilution were practiced. ${ }^{2}$ In addition, the fact that different cows and herds produce milk varying in richness was also recognized. When the states began to establish the office of "Dairy and Food Commissioner,"

\footnotetext{
${ }^{1}$ Report of the Transactions of the N.Y. State Agricultural Society for 1863 , p. 172 .

2 The N. Y. State Cheese Manufacturers' Association petitioned the legislature to pass a law prohibiting dilution with water, adulteration in any way, taking of cream, or holding back strippings. In 1864 the legislature passed an act entitled, "To Protect Butter and Cheese Manufacturers".
} 
the need for an accurate and simple test was also greatly felt. It was necessary that the test be absolutely accurate. because prosecutions would be based on the results of the test if they should show adulteration or dilution. The process had to be expeditions because inspectors were called upon to make a great many tests. Prof. Edward W. Martin, of the School of Mines, Columbia University, was employed as chemist by the first Dairy Commissioner of New York State, and had charge of the force of milk inspectors. He devoted considerable time to the problem of finding a suitable test. ${ }^{1}$

Practically everywhere creameries, cheese factories, and condenseries now buy the milk on the basis of the fat test and not by weight or bulk. This is, of course, only fair. The U. S. Agricultural Experiment Stations have conducted experiments the results of which show that the percentage of fat in the milk of the different breeds of dairy cows varies widely. The average yield of butter fat of the Holstein cow is found to be 3.45 per cent; of the Ayrshire cow, 3.85 per cent; of the Guernsey cow, 4.98 per cent; and of the Jersey cow, 5.I4 per cent. $^{2}$ It is to be expected, of course, that the yield of fat of individual cows would vary considerably from the average yield of a breed. The fat content also varies considerably in a single cow at different times during the period of lactation. The importance of paying for milk on the basis of the fat test is more apparent in butter-making than in cheese-making, because the number of pounds of butter that can be made from the milk varies almost directly with the percentage of fat in the milk. Viewing the problem, therefore, from the side of the manufacturer, it is important that he pay a

${ }^{1}$ Vide, N. Y. State Dairy Commissioners' Report for 1885.

${ }^{2}$ Bulletin 156, Bureau of Animal Industry, U. S. Department of Agriculture. 
correct price for his milk in order that he may successfully compete. From the farmers' viewpoint, the justice of the method must also be recognized. The farmer who has spent much time and money in developing a pure-bred dairy herd has more valuable property than the farmer with the "general-purpose" cows, and in order that the return on this form of capital may be in all cases equal to what it produces it is necessary to sell the milk on the basis of the fat that it contains. It need not be said that this method eliminates the evil of adding water and enforces honesty among all the patrons.

The principles upon which the Babcock tester is based are chemical action and centrifugal force. Commercial sulphuric acid is added to the milk to break up thoroughly all milk solids, other than the fat, which is set free by the action. The fat can then be very easily separated by centrifugal force. The mixture is put in a bottle and the bottle then placed in a pocket of an apparatus by which it is whirled for five minutes or more, after which the fat appears in the neck of the bottle. The neck of the bottle is graduated to show the percentage of fat in the milk. The method is very accurate and so simple that a person of ordinary intelligence can make the test. Furthermore, it can be done quickly, which is a great advantage for use in the creamery as well as for purposes of inspection.

The idea of first treating the milk chemically and then subjecting it to centrifugal force was tried out in Europe before Dr. Babcock of this country perfected the method. For instance, Dr. De Laval, of Stockholm, one of the inventors of the separator, used a mixture of glacial acetic acid and sulphuric acid, with which he treated the milk and then whirled it in an apparatus which he called the lactocrite. ${ }^{1}$ According to the account of the tests made, the

${ }^{1}$ Nezu York State Dairy Commissioner's Report for 1888, pp. 242-3. 
results obtained were not accurate and the experiment was not as easily performed as that of the Babcock test.

The honor for perfecting the fat test belongs to Dr. S. M. Babcock, an eminent American chemist and investigator of dairy problems. $\mathrm{He}$ was formerly associated with the New York Experiment Station at Geneva, but for many years has been connected with the Wisconsin Experiment Station. This invention might have been patented, and would have brought a great fortune to Dr. Babcock, because, next to the separator, it is the most important invention used in the dairy industry. It has a wide sale, and is in general use not only in this country but in Europe. Instead of securing a patent, however, Dr. Babcock gave this invention to the world as a public benefaction. Dr. Babcock is therefore honored not alone for his genius and for the industry which he displays in his investigations, but for his unselfish interest in the dairy industry and in the progress of mankind.

THE INTRODUCTION OF THE HAND SEPARATOR

The hand separator was introduced about I894. Its more rapid introduction dates from $1898 .{ }^{1}$ The effect of the general use of the power separator made it necessary to deliver the whole milk at the creamery or at skimming stations where milk is separated and where the farmers get their share of the skim milk to take back to the farm. Frequently, however, this milk is run into a tank and allowed to accumulate, the result of which is that the skim milk deteriorates and loses considerable food value. The use of the hand separator enables the farmer to feed his skim milk in its very best condition to hogs or calves.

When the power separator came into general use it was necessary to establish numerous skimming stations, in

${ }^{1}$ H. E. Van Norman, First Lessons in Dairying, p. 88. 

"The statement on page 29 as to Vermont is no longer true, as the system in question has recently been discontinued." 
sparsely-settled sections, notably in the West, in order that sufficient quantities of cream could be collected. The cream from these skimming stations was shipped to the creamery where the milk from nearby farms was separated and where all the cream was churned. This system was also followed in some Eastern sections. In northern Vermont, for instance, a creamery company has a number of skimming stations located all through Franklin County and some in adjoining counties where the farmers' milk is separated and whence the cream is shipped to the creamery at St. Albans to be churned. In the Western States, however, skimming stations have been more numerous, and when the hand separator came it had the effect of eliminating a great many skimming stations throughout this section of the country, because the farmers separate their milk on the farm and ship the cream long distances to a creamery. Thus, the hand separator has brought back into use a system of gathering cream instead of whole milk. It will be remembered that only the cream was collected by creameries organized on the Cooley or Fairlamb plan. The great producers in the Middle West, known as "centralizers," have most of the cream separated by the farmers and shipped to them over the railroad.

The system by which the skimming station is used to collect the cream at a central point, there to be churned, is by far the most satisfactory system from the manufacturers' point of view. The cream is better taken care of and is more uniform in quality, the result of which is that better butter can be made. Where the hand separator is used the cream is sometimes kept too long, and frequently improperly cared for. The result is that when this cream reaches the creamery numerous lots of cream of different degrees of ripeness and varying in purity are worked up together, making a grade of butter that cannot be as good as butter made of cream collected by means of skimming stations. 
Ever since the hand separator came into general use the creameries have tried to improve the quality of the cream. There are some obstacles in the way. In the first place, the hand separator must be thoroughly washed and sterilized every time it is used in order to prevent the growth of pernicious bacteria and their transmission into the newly-separated cream. The importance of sterilization is, of course, not always appreciated, and this causes a great deal of mischief. In the second place, there is frequently keen competition among producers, and in the effort to secure all the cream available, terms that encourage laxity in the care of the cream are sometimes made with farmers. Attempts are being made, however, to remedy the evil by paying for cream according to quality. In general, the plan is to pay more for sweet cream than for sour cream. This, of course, presupposes coöperation among the creameries in a given section of the country.

\section{RECENT CHANGES IN METHODS OF PRODUCTION}

Nature has provided a special bacterium, called the lactic acid bacillus, to sour milk or cream. When cream is allowed to ripen naturally preparatory to churning, it is due to the development of these bacilli that always manage to get into milk. It takes considerable time, however, for the cream to ripen naturally, and in order to avoid this delay creameries now generally use home-made or commercial "starters". The commercial "starter" is prepared by isolating the lactic acid bacilli and cultivating them in a suitable medium. By the use of the "starter" the time of ripening can not only be controlled, but the flavor of the butter can be improved, since good flavor is believed to be largely dependent upon the predominance of lactic acid bacteria over other bacteria in the cream. Too much acidity in the cream, however, produces a "fishy flavor" in 
the butter. The "starter," therefore, is especially valuable in making possible systematic control over the flavor of butter.

Pasteurization ${ }^{1}$ is the process of heating a sulsstance to a temperature at which bacteria are killed. This is done with milk consumed in some American cities. It is also done with cream in some creameries in America, and in Denmark it is the universal practice. The butter of Denmark has therefore a uniform quality and a distinctive flavor. According to observations made by the Dairy Division of the $L$. S. Department of Agriculture, ${ }^{2}$ the best results in the pasteurization of cream used for making butter are obtained by heating it momentarily to a temperature of not lower than 165 degrees Fahrenheit nor higher than 175 degrees Fahrenheit. If the cream is pasteurized in a vat or holding device, lower temperatures may be used. An examination of the butter after it has been in storage indicates that pasteurization at I50 degrees or lower leaves in the cream some factor that causes deterioration in the butter. At I60 degrees this is not the case. At ISo degrees the heating affects the flavor of the butter.

The reasons for pasteurizing the cream are to increase the keeping quality of butter and to protect the public health. When cream is pasteurized the bacteria that were in the milk and cream cannot be carried into the butter. It is, of course. important that the germs of typhoid, diphtheria, scarlet fever, dysentery, tuberculosis, ctc., be destroyed. Under perfect sanitary conditions these germs should not appear

${ }^{1}$ This process is named after Dr. Pasteur, who experimented on "diseases" of wine in France and found that abnormal fermentations in wine could be prevented by heating for a few moments to a temperature of 122 to I40 degrees Fahrenheit. Vide, Circular I84, Bureau of Animal Industry, U. S. Department of Agriculture.

${ }^{2}$ Circular 189 , Bureau of Animal Industry, U. S. Department of Agriculture. 
in the milk. Water, however, is frequently contaminated with typhoid and other disease germs, and when milkpails and milk-cans are washed with cold water and not thoroughly sterilized with boiling water, a typhoid epidemic is the result. This is not only a problem in the consumption of city milk, but is also a source of danger in the consumption of butter; though the danger in milk consumption is greater than in the consumption of butter for the reason that the growth of bacteria in fat is slow and in salted butter especially so. However, the bacteria that find their way into the butter, while they cannot develop rapidly, are nevertheless a menace to the public health, and it is especially important that the germs of typhoid, diphtheria, and tuberculosis be either excluded from the cream by a system of rigid inspection, which is well-nigh impossible, or by pasteurization. $^{1}$

Milk contains certain enzymes which are believed to be vital substances and are a near approach to "life". 2 These enzymes promote growth, and are therefore especially beneficial in food for children. In the interest of public health and from the point of view of dietary efficiency, the pasteurization of cream to be used in making butter for fresh consumption should not be at a temperature that will destroy these enzymes. In order, however, that the keeping quality of butter to be held in cold storage may be improved, it is desirable to raise the temperature of pasteurization to the death points of the enzymes, because investigation indicates that they play a part in the deterioration of butter. ${ }^{3}$

${ }^{1}$ Vide, Circular I53, Bureau of Animal Industry, U. S. Department of Agriculture.

${ }^{2}$ Ibid.

${ }^{3}$ Circular I89, Bureau of Animal Industry, U. S. Department of Agriculture. 
During the last decade large creameries have attempted to increase the quantity of butter to be made from a given amount of butter fat. The cream that is delivered by the farmer contains a certain anount of fat determined by testing. If butter contained nothing else but fat, the finished product should amount to a little less than the quantity of the butter fat in the cream after allowance for wastage is made. In addition to the fat, however, the butter contains water, casein or curd, milk sugar, and other substances. Salt is also added. The presence of these constituents in the butter makes the quantity of finished butter considerably greater than the amount of pure fat that it contains. The more water and other substances that can be added to the butter fat, the larger will be the quantity of finished butter. The increase of the finished product due to water and substances other than fat is known as the "overrun". Expressed as a percentage, the "overrun" is "the per cent which the weight of the constituents other than butter fat is of the weight of the fat in a given quantity of butter". In large creameries the amount to be gained from an increase of the "overrun" is very considerable, while in a small creamery the gain is of less importance. It was in the large centralizers, therefore, that this matter was given much attention. These large plants get an "overrun" of $2 \mathrm{I}$ to 24 per cent, while for the average of ten small creameries in 1904 it was I 2 or I 3 per cent, increasing to 20 per cent by I9II. ${ }^{2}$

The problem of increasing the "overrun" was soon taken up by various schools and state dairy commissioners, and was discussed in dairy conventions. The State Dairy

${ }^{1}$ Bulletin 164, Bureau of Labor Statistics, U. S. Department of Labor, p. I3.

${ }^{2}$ Ibid. 
Commissioner of Iowa in 1905 urged creameries and buttermakers to give this subject special attention, pointing out that a difference of only 5 per cent in the "overrun" would amount to more than \$IIO a month for the average creamery in Iowa. ${ }^{1}$ The Iowa State College had made experiments showing that the "overrun" could be increased to 25 per cent. This would reduce the percentage of fat in butter to about 80 per cent, which was 2 per cent lower than the legal standard for butter in many of the states. ${ }^{2}$ It would also bring the butter within the meaning of adulterated butter under the federal law, because the amount of water that normal butter may contain according to a regulation made by the Internal Revenue Commissioner under the act of May 9th, I902, is 16 per cent. In Michigan the office of the Dairy and Food Commissioner endeavored, as related at the State's dairy convention, to secure an "overrun " of $16 \% 3$ per cent for the creameries. ${ }^{3}$

Eager to increase the profits of butter-making, many creameries increased the "overrun" to the extent that more than I6 per cent of water was included. This led to prosecutions, because the product was sold as ordinary butter while according to the federal law it is classified as adulterated butter upon which a tax of Io cents a pound must be paid and a special annual tax by the manufacturers and dealers selling the product. The Internal Revenue Commissioner finds it difficult to enforce the law, and says it costs more to enforce it than is received as revenue. $\mathrm{He}$ urgently recommends revision of this law, therefore, on the ground that it is unsatisfactory from both an administra-

1 Annual Report of the State Dairy Commissioner of Iowa for I905, p. I2.

${ }^{2}$ Vide, legal standards for dairy products, Agricultural Yearbook for I9I3.

${ }^{3}$ Report of Michigan Dairy Association for 1906, p. 335. 
tive and revente standpoint. The farmer and creamery should, of course, be allowed a reasonable "overrun", but it does not seem fair to make the consumer pay for an undue portion of water included in the butter.

Special products and the utilization of by-products are receiving more and more attention in the dairy industry. In recent years many creameries have installed machinery for the manufacture of ice-cream. ${ }^{1}$ There is some risk attached to this enterprise because the demand for ice-cream cannot always be readily estimated. The manufacturer must pay attention to the changes of the weather, to holidays, and to special events, such as picnics, conventions, etc. The extent of the demand for this product in rural communities and small towns is largely dependent upon conditions under which it may be bought. If creameries can make its accessibility easy to prospective customers, they may expect an important gain from a portion of the cream that otherwise would have to be sold at a lower profit in the form of butter. According to reports from creameries received by the Dairy Division of the U. S. Department of Agriculture, the profits on a pound of butter fat in making ice-cream are $5 \mathrm{I}$ cents more than in making butter. $^{2}$

The most important by-products of the creamery are skim milk and butter milk. Creameries that receive handseparated cream exclusively have, of course, no skim milk, and in this case the skim milk is left on the farm in a good condition. When whole milk is received at the creamery the farmers take the skim milk back with them, although, owing to the fact that it is run into a large tank and allowed to stand some time, it is frequently not very good feed for

${ }^{1}$ Circular 188, Bureau of Animal Industry, U. S. Department of Agriculture.

${ }^{2}$ Ibid. 
hogs. Another objection to this method is that the milk of tubercular cows is mixed with the milk of all the corvs in the community, and unless the skim milk is pasteurized it is liable to spread bovine tuberculosis if fed to calves and hogs. The transmission of bovine tuberculosis to hogs through feeding butter containing tubercle bacilli or by allowing hogs to have access to the feces of tubercular cows, has been positively demonstrated. ${ }^{1}$ The problem of guarding the public health against the spread of the "white plague" therefore not only requires that milk and cream for fresh consumption and milk and cream used to make butter and cheese be pasteurized, but that efforts be made to prevent the spread of the disease among cows ancl hogs. Some authorities deny that bovine tuberculosis can be transmitted to man; the weight of opinion, however, seems to be on the other side: and in view of the fact that it may be easily transmitted to hogs, it is by far the wisest plan to take all precautions possible in the protection of the health of the people. Aside from its relation to public health, bovine tuberculosis is an important economic problem. Large numbers of hogs are fed skim milk, and the infection of hogs with tuberculosis means a loss to the farmer.

The hog may be considered a very impurtant by-product of the butter industry. In Denmark the feeding of skim milk to hogs is considered so important that coöperative efforts have been made to develop the so-called "bacon hog". This hog is raised for its bacon and lean meat primarily, and may be distinguished from the "lard hog" which is fattened so as to yield large quantities of lard. In $1887^{2}$ the Danes organized their first coöperative bacon

${ }^{1}$ Circulars $I 18$ and 153 , Bureau of Animal Industry, U. S. Department of Agriculture.

${ }^{2}$ Edwin A. Pratt, Agricultural Organiation, p. 12. 
factory, where the bacon and other products of the hog are prepared for the market. The "bacon hog" has been discussed at dairy conventions in this country, and since the general introduction of the hand separator in many sections of the North Central States farmers have paid more attention to the development of this source of their

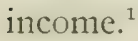

All creameries produce buttermilk, which is now considered a valuable by-product. This could also be returned to the farmers, but is usually considered the property of the creamery. Frequently it is wasted. Sometimes it is sold at nominal prices. Of late, at the larger and more enterprising creameries, it either has been sold at fair prices to be consumed as a beverage or has been fed to hogs owned by the creamery proprietors. Buttermilk has great therapeutic value in the treatment of intestinal disorders, and is recommended by physicians for this purpose. Hospitals use large quantities of it. ${ }^{2}$ In reports rendered by creameries to the Dairy Division of the Department of Agriculture important profits made by feeding buttermilk to hogs are announced. ${ }^{3}$ After deducting the cost of the grain and not counting labor, the profits due to buttermilk among the creameries reporting show considerable variation. An Iowa creamery reports a profit of $\$ 43.20$ from feeding 12 hogs for 42 days and selling them at 8 cents a pound.

Dried casein is also a by-product of some creameries. It is made from skim milk or buttermilk. According to the census, I2,298,405 pounds of dried casein were made in the

${ }^{1}$ Repart of the Michigan Dairy Association for 1899, p. 83, and for I II I, p. 98.

${ }^{3}$ Circular I7I, Bureau of Animal Industry, U. S. Department of Agriculture.

${ }^{3}$ Circular 188, Bureau of Animal Industry, U. S. Department of Agriculture. 
United States in 1900 . It has also been discovered recently that a horn-like substance called galalith can be made with dried casein. The substance is smooth and is proof against fire. It is used as a substitute for ivory, celluloid, marble, hard rubber, and even amber. ${ }^{1}$ In the manufacture of dried casein in 19 Io the returns of 100 pounds of skim milk were 25 to 30 cents. $^{2}$

\section{THE GROWTH OF THE FACTORY SYSTEM}

The growth of the factory system in the manufacture of butter may be shown by a comparative statement of changes in the farm and factory products. While the factory method was begun in I86I, the first mention of a butter factory made in the United States Census was in 1880. The increase in the factory output as well as the total amount of butter produced in the United States from $185^{\circ}$ to I9Io are shown in Table no. 2.

The farm product increased steadily from I 850 to 1880

TABLE II

The Amount of Butter Produced in the United States on the FARM AND IN THE FACTORY FROM 1850 TO 1910

\begin{tabular}{|c|c|c|c|}
\hline Census Year & Total product & On Farms & In Factories \\
\hline & pounds & pounds & pounds \\
\hline r $850 \ldots \ldots \ldots \ldots \ldots$ & $313,345,306$ & $313,345,306$ & ............ \\
\hline $1860 \ldots \ldots \ldots \ldots \ldots$ & $459,681,372$ & $459,681,372$ & ... \\
\hline $1870 \ldots \ldots \ldots \ldots \ldots$ & $514,092,683$ & $5^{14}, 092,683$ & $\ldots \ldots \ldots \ldots$ \\
\hline $1880 \ldots \ldots \ldots \ldots \ldots$ & $806,672,071$ & $777,250,287$ & $29,421,784$ \\
\hline $1890 \ldots \ldots \ldots \ldots \ldots$ & $1,205,508,384$ & $1,024,223,468$ & $181,284,916$ \\
\hline $1900 \ldots \ldots \ldots \ldots \ldots$ & $1,491,871,673$ & $\mathrm{I}, 07 \mathrm{I}, 745, \mathrm{I} 27$ & $420,126,546$ \\
\hline $1905 \ldots \ldots \ldots \ldots \ldots$ & ....................... & 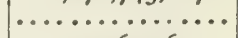 & $53 I, 478,14 I$ \\
\hline $1910 \ldots \ldots \ldots \ldots \ldots$ & $1,619,415,263$ & $994,650,6$ го & $624,764,653$ \\
\hline
\end{tabular}

(From Statistical Abstracts of the United States.)

- Special Census, 1905, Part III, p. 312.

${ }^{3}$ Circular I88, op. cit. 
and rather rapidly in the succeeding decade; but between 1890 and 1900 the increase was very small, and between I 900 and I9Io there was a decrease. The factory product shows a rapid increase between $\mathrm{r} 880$ and $\mathrm{I} 890$. During this decade the power separator became popular. From I890 to 1900 there was also a large increase, which was probably due to the general introduction of the hand separator in connection with the rapid expansion of railroad transportation that had been going on during the previous decade. The railroad mileage of the country grew from 93,296 miles in 1880 to 163,597 in I 890 . The greater portion of this unprecedented construction was carried on in the Central and Western States, where agriculture and mining were being developed. ${ }^{1}$ The butter product of the factory in 1905 and I9Io shows a steady gain. With transportation facilities developing and the division of farm land into medium-sized units in progress, it may be expected that the factory product will continue to grow. The superior quality of the factory product over the farm product will eventually force dairy butter entirely out of the city market. In the consumption of butter on the farm the substitution of creamery butter for dairy butter will probably be somewhat less rapid than it has been in the city. The rate of growth of the factory product in succeeding decades may therefore be expected to be relatively slower than it has been during the early decades of the factory system.

As previously stated, the production of cheese in America has been almost wholly transferred to the factory. It is interesting to inquire why the change from the domestic system to the factory system in the manufacture of butter has been much slower. It would seem that there are two

${ }^{1}$ Vide, E. L. Bogart, Economic History of the United States, p. 317. 
principal reasons for this, the first one being that the domestic manufacture of butter is a simpler operation than the domestic manufacture of cheese, and the second that the amount of capital reguired per establishment in the factory production of butter is considerably greater than in the factory production of cheese. It requires expert skill and information to manufacture cheese. Few people know anything about the process of cheese-making. Butter-making, on the other hand, is comparatively simple. With great care, just as good butter can be made on the farm as in the factory. As far as the equipment for making the two products on the farm is concerned, cheese-making is also at a disadvantage. The ripening process makes necessary a large curing room. For butter-making an inexpensive churn and a few other utensils complete the equipment. Conditions on the farm, therefore, exert a much greater force in transferring cheese-making from the home to the factory than in transferring butter-making. Viewing the problem from the standpoint of the factory, the equipment is found to be much less in cheese-making than in butter-making. In I9ro the capital per establishment in cheese-making was $\$ 2,536$, while in butter-making it was $\$ 8,994 \cdot{ }^{1}$ Part of this difference is due to the fact that in the butter industry greater concentration is possible than in the manufacture of cheese. It is more profitable to transport cream long distances than whole milk, and considerable concentration in the butter industry has therefore occurred during the last decade. In I900 the capital per establishment in buttermaking was only about double that of cheese-making. Under existing economic conditions it must be more advantageous for butter-making to concentrate, but it is by no means necessary in regions more or less thickly popu-

\footnotetext{
${ }^{1}$ Computed from census figures.
} 
lated. In view of the fact, then, that the capital per establishment in butter-making must be greater than in cheesemaking, the tendency toward factory production must be less in the former than in the latter.

The following statement shows changes in the number of establishments from I 890 to I9IO due to the introduction of the hand separator and to concentration:

Census year

1890

1900

1910
No. of Establishments

$455^{2}$ (Butter, Cheese and Condensed-milk Establishments).

5275 (Creameries)

4783 (Creameries)
Pounds Cream purchased $483,630,74 \mathrm{I}$

$203,673,95^{8}$

I, $406,143,908$

The number of establishments increased from 1890 to I900, but decreased during the next decade owing to the fact that the hand separator made it possible to gather large quantities of cream over a wide territory and churn it at a central point. The rapid introduction of the hand separator dates from about I898. The general use of the power separator from 1890 to 1900 caused an increase in the number of establishments and also a decline in the cream-gathering system. In the next decade, however, when the hand separator superseded the power separator in many sections of the country the cream-gathering system was restored. These changes are also indicated by the number of pounds of cream purchased. In Igoo there was a decrease in the amount of cream purchased for the reason that at that time the use of the power separator made it necessary to purchase whole milk. In consequence of the introduction of the hand separator there was, of course, a rapid decline in the number of skimming stations that became prominent before I900. These separated the whole milk in remote communities and shipped the cream to the creamery to be churned. This system is still in use in some 
eastern sections but has been discontinued in many sections of the North Central States in favor of separating the cream on the farm. The number of skimming stations in 1900 was 2,050. The change during the succeeding five years was so rapid that by 1905 the number had decreased to $\mathrm{I}, 602$.

Concentration in the butter industry may be more definitely shown by the following statement:

$\begin{array}{cccc}\begin{array}{c}\text { Census } \\ \text { Year }\end{array} & \begin{array}{c}\text { No. of } \\ \text { Establishments }\end{array} & \begin{array}{c}\text { Product per } \\ \text { Establishment }\end{array} & \begin{array}{c}\text { Capital per } \\ \text { Establishment }\end{array} \\ 1900 & 5,275 & 53,329 \text { lbs. } & \$ 3,927^{1} \\ 1905 & 5,235 & 60,582 \text { “ } & 5,746 \\ 1910 & 4,783 & 130,622 \text { “ } & 8,994\end{array}$

The statement shows that in the ten years from 1900 to I9IO there was a substantial decrease in the number of establishments and an increase of more than double in the average output. The capital per establishment has also increased. The evidence is very plain, therefore, that during this period concentration has proceeded rather rapidly. Whether or not concentration in the butter industry proceeded from i 880 to I9Io cannot be separately shown because the census figures combine in most cases butter, cheese, and condensed-milk factories. In order that an idea as to whether or not concentration in the dairy industry as a whole has been in progress from the beginning of the factory system to the present, the following statement of combined establishments of butter, cheese, and condensed-milk factories is given:

The average capital of all butter, cheese, and condensed-milk establishments. The following two amounts are for butter establishments only. 


$\begin{array}{cccc}\begin{array}{c}\text { Census } \\ \text { Year }\end{array} & \begin{array}{c}\text { No. of } \\ \text { Establishments }\end{array} & \begin{array}{c}\text { Capital per } \\ \text { Establishment }\end{array} & \begin{array}{c}\text { Average Value of Products } \\ \text { per Establishment }\end{array} \\ 1880 & 3,932 & \$ 2,443 & 6,547 \\ 1890 & 4,552 & 3,519 & 13,321 \\ 1900 & 9,242 & 3,927 & 14,15 \mathbf{I} \\ 1905 & 8,926 & 5,295 & 18,842 \\ 1910 & 8,479 & 8,406 & 32,38 \mathbf{i}\end{array}$

The great increase of the average value of output in ISgo over ISSO was partially due to the fact that the price of dairy products was somewhat higher in 1879 than in 1889 . The annual average butter price for 1889 was about two cents higher than for I879. However, the difference in price can not alone account for the great increase in the value of the output. During this decade creameries installed the power separator and established skimming stations in outlying districts, and in this way enlarged the establishment and increased its output.

The more important movement toward concentration began after I89o. As already stated, this was in the butter industry and was due to the introduction of the hand separator. Concentration in the manufacture of cheese and condensed milk cannot extend as far as in the manufacture of butter, because in the former two industries whole milk must be brought to the factories, while in butter-making cream may be received. The transportation charge of the raw material in cheese-making and the manufacture of condensed milk is therefore considerably more than in the manufacture of butter. 


\section{CHAPTER II}

ORGANIZATION FOR THE PRODUCTION OF BUTTER

THE organization for the production of butter may be treated under two general headings. The first concerns the production of the raw material, and includes a study of the cov-testing and breeding associations and societies for buying and selling; and the second has to do with the organization of the factory, the prevalence of the different forms of organization, and their geographic distribution.

\section{THE COW-TESTING ASSOCIATION}

The cow-testing association is an organization among dairy farmers formed for the purpose of ascertaining accurately the net income received from each cow.

The cow-testing association had its origin in Denmark in I892. ${ }^{1}$ The idea was first conceived by State Counselor B. Boggild and outlined at a meeting of the Kildebrond Creamery patrons. Fourteen farmers agreed to weigh their milk and furnish samples to the creamery manager to be tested by him. The results of the records kept by this small group of men led to the organization of the Kildebrond Bull Association, which was formed for the purpose of improving the herd. The latter organization was a natural consequence of the results of the tests made, and opened the way to weed out the unprofitable cow by replacing her with a highly productive cow. The first formal coöperative cow-testing association in Denmark was organized

${ }^{1}$ Vide, Circular I79, Bureau of Animal Industry, U. S. Department of Agriculture. 
January 23, I895. at Lille. Skorgaard, Vejen. The association began with I 3 members, but by 1909 their number had increased to $2+$ members. At that time the total number of cows owned by the members was 522 , and two men as cow-testers were employed. The movement soon spread all over Europe. In I909 Denmark had 530 cow-testing associations. Germany had 207. Sweden had 662, Norway had I46, Finland had 99, and in I907 Holland had 86. The movement spread also to Russia, where there were in the neighborhood of 50 associations in 1909 .

In the Lnited States the first cow-testing association was organized at Fremont. Michigan, September 26, I905. under the name of the Newaygo County Dairy Testing Association. The initiative in organizing this association was taken by the office of the Michigan State Dairy and Food Department. Thirty-one members joined the association, and regular tests of 239 cows were made during its first year. Since then the morement has grown steadily in the United States. In 1909 there were 32 associations distributed among nine states, as follows: Michigan, 5; Maine, 5; Wisconsin, Io; Vermont, 5; California, 2; Iowa, 2 ; Pennsylvania, I; Ohio, I; Washington, I. Many more were organized in I9IO. By I9I 2 there were II8 associations. Only 97 of these, however, were active. ${ }^{1}$ The Wisconsin Dairymen's Association for over six years has aided the farmers of its state to organize associations. In I9I3 IVisconsin had $2 \mathrm{I}$ associations with a membership of 560 dairymen, and the cows whose milk was tested numbered $8,800 .^{2}$ In New York the total number of associations in I9I 3 was $22 .^{3}$ There is a tendency at times among mem-

\footnotetext{
${ }^{1}$ Agricultural Yearbook for 19I2, p. 49.

${ }^{2}$ Hoard's Dairymen, Dec. 9, I9Iо, p. 6rо.

${ }^{3}$ Ibid., p. 618.
} 
bers of cow-testing associations not to appreciate fully the value of regular tests, and as a consequence the association may become inactive. The greatest obstacle to success, however, is the inability to secure efficient men to supervise the associations. ${ }^{1}$

The movement of organizing cow-testing associations has been helped considerably by the U. S. Department of Agriculture. The Dairy Division of the Bureau of Animal Industry has prepared the necessary forms and books for keeping records of the tests of the cows. These blank forms have been furnished free of charge to groups of farmers wishing to organize. Men to superintend the details of organizing have also been sent into communities where these services have been requested. State dairy departments and state dairy associations are also active in establishing associations and helping them to bridge over difficulties. Some states furnish free of charge all necessary forms and books to keep the records as well as testing and weighing outfits.

Following is a copy of the constitution and by-laws in use by cow-testing associations: ${ }^{2}$

CONTRACT USED IN THE ORGANIZATION OF A COW-TESTING ASSOCIATION

Whereas the - Dairy Testing Association has been organized for the principal purpose of providing means for the coöperation of its members in testing the milk of their cows periodically and for otherwise improving their dairy interests; and whereas it is proposed by said association to engage a suitable person as soon as enough subscriptions are obtained to warrant said association in engaging such person, we, the un-

${ }^{1}$ Secretary of Agriculture in Agricultural Yearbook for 19I2, p. 49.

${ }^{2}$ Vide, Circular 179, Bureau of Animal Industry, U. S. Department of Agriculture. 
dersigned members of said association, each for himself and not one for the other, agree to pay the sum of —_ for each cow set opposite our respective names to said association for that purpose. Said fees to be paid in quarterly installments in advance, the first payment to be made as soon as such person is engaged by said association. Each one of us also agrees to furnish board and lodging for said person for at least one day each month and convey him to his next place of work. Said person shall not work Sundays, but shall have board and lodging over Sunday at the place where he is working Saturday.

CONSTITUTION AND BY-LAWS FOR A COW-TESTING ASSOCIATION

\section{Articles of Association}

We the undersigned, desiring to become incorporated under the provision of act No. - (of the public acts of - - ) entitled - and the acts amendatory thereof and supplementary thereto, do hereby make, execute, and adopt the following articles of association, to wit:

Article I. The name by which this association shall be known in law is - Dairy Testing Association.

ARTIClE II. The purpose for which it is formed is generally to promote the dairy interests of its members and particularly to provide means and methods for improvement of the dairy qualities of cows and for the testing of the cows of its members periodically.

ARticle III. Its principal office and place of business shall be at

ARTICLE IV. The number of its directors shall be -

ARTICLE $V$. The names of the directors for the first year of its existence are as follows:

Article VI. Any person may become a member of this association and be entitled to its benefits and privileges upon being accepted by the board of directors and upon complying with the requirements of the by-laws. 


\section{By-laws}

Article I. Meetings.-An annual meeting of this association shall be held at a place to be designated by the board of directors, in - on the day of - in each year, at 2 o'clock p. m., for the purpose of electing a board of directors, and for the transaction of such other business as may lawfully come before said meeting.

The president shall call one meeting each month for the purpose of discussing topics of interest to dairymen and shall at each meeting appoint a committee of three members who shall prepare a programme for the next meeting. No member shall be obliged to serve two months in succession on this committee.

Special meetings may be called by the board of directors or by the president, and notice thereof shall be given by the secretary, by mailing to each member a written or printed notice thereof at least five days prior to such meeting. Such notice shall state the object of the meeting and no other business shall be transacted thereat.

Article II. Board of Directors.-Section I. The board of directors shall be elected at the annual meeting, the first election to be held on the —- day of — A. D. -

Section 2. The board of directors shall have the management and control of the business of the association, and shall employ such agents as they may deem advisable, and fix the rates of compensation of all agents and employees.

Section 3. Whenever any vacancies occur in the board of directors by death, resignation, or otherwise, the same shall be filled without undue delay by the majority vote of the remaining members of the board. The person so chosen shall hold office until the next annual meeting or until his successor is elected and qualified.

Section 4. The board of directors shall meet on the first of each month, at such hours and in such places as they may by resolution determine.

Section 5. A majority of the board of directors shall constitute a quorum at all meetings of the board. 
Article III. Officers-Section I. The officers of the association shall consist of president, vice-president, secretary, and treasurer. The officers of secretary and treasurer may be held by the same person. The officers shall be elected by the board of directors from their own number by a majority vote of the whole number of directors. The first election shall be held immediately after the election of the board. Subsequent elections shall be held annually on the day of the regular meeting of the board, next ensuing after the annual election, the day to be fixed by resolution of the board of directors.

Section 2. In case of death, resignation, or removal of any officer the board shall elect the successor, who shall hold office for the unexpired term.

Article IV. Membership.-Any person acceptable to the board of directors may become a member upon paying a membership fee of 25 cents.

Article V. Dues.-Each member shall pay a fee of 25 cents annually on or before the _- day of —_ ; and in addition thereto shall pay quarterly dues to cover his share of the expense of cow-testing, in proportion to the number of cows he has to be tested, the amount of such quarterly dues to be fixed by the board of directors, and paid as specified in a contract to be made for this purpose between the members. No member shall be allowed to participate in the election of the board of directors who shall not have paid his annual dues in advance.

Article VI. Amendments.-These by-laws may be amended or added to by a majority vote of all the members present at the annual meeting or at a special meeting called for the purpose.

The expenses of the association consist of the salary of the tester and such small items as sulphuric acid and postage. When the association must buy a testing outfit and weighing apparatus this is a special expense item that is usually paid for by levying assessments upon the members. 
The payment of the tester's salary is apportioned among the members according to the number of cows that they contract to have tested by the association. This is the largest expense item. Each member agrees to pay $\$ \mathrm{I}$, or in some associations $\$ 1.50$, per cow a year, and to give board and lodging to the tester during the time that he is testing his cows. When the number of the cows in an association is 500 , at the rate of a fee of $\$ I$ per cow, the tester has a yearly salary of $\$ 500$, in addition to board and lodging. In the contract signed by the members of the association pledges are given to provide the necessary fund out of which the tester's salary is paid.

In order that each cow may be tested once every month, it is necessary that the herds number only 26 , because there are 26 working days in a month and the testing of one herd is usually all a tester can do at one milking. If two testers are employed, the number of herds can of course be doubled. The tester must be able to operate the Babcock tester and make simple calculations and record these in the farmer's book. He must also be prepared to give advice as to feeding a properly-balanced ration. Matters of feeding and care are usually discussed in the evening.

At monthly meetings of the association the members also discuss problems that arise, and business is usually combined with pleasure. The object of these cow-testing associations, as stated before, is to determine the net income from each cow. This is an innovation among farmers and goes right to the root of the problem of how to increase the yield of the milk. The effect of these cow-testing associations is therefore going to be far-reaching. $U^{\top} p$ to the present time the great majority of farmers have done very little bookkeeping and they know absolutely nothing of the relative costs of their crops. In business it would be regarded as ludicrous not to keep books, and it is time that 
farmers recognize the fact that it is impossible to determine, the relation of cost to income of their various products unless accurate records are kept. Many members of cow-testing associations have found that their notions as to the value of individual cows in their herds were altogether wrong. It would appear, therefore, that the systematic method used in these associations will in time cause farmers to extend the idea of keeping records to other farm operations. The keeping of records in dairy farming has led to scientific feeding, weeding out the "boarder cow," and breeding up the herd. The results of feeding a balanced ration are realized at once. Much may be done by disposing of unproductive cows and getting good ones. Naturally, however, there is a limit to this method, because good cows must first be bred before the whole community can be supplied. It takes a few years until profits are realized from scientific breeding, and this fact tends to check the improvement of herds. Breeding up the herd, however, offers great possibilities, and any enterprising dairy farmer realizes that this is what he must do if he would increase his profits beyond the limitations of the scrub cow. Scientific breeding in every community of America and other dairy countries of the world will very appreciably increase the food supply of the people, and will therefore have very important social results.

In Table no. 3 the yearly averages per cow of the Michigan Newaygo County Dairy Testing Association 2 are given. This is a record of the first four years' work of this association and shows that both the percentage of the fat in the milk and the quantity of milk have been very substantially increased. The profits of each cow have steadily increased, and during the four years have been practically

${ }^{1}$ Vide, Circular 179 , Bureau of Animal Industry, U. S. Department of Agriculture, p. 16. 
TABLE III.-Yearly Averages per Cow of

\begin{tabular}{|c|c|c|c|c|c|c|}
\hline Year & $\begin{array}{c}\text { Number } \\
\text { of } \\
\text { Cows }\end{array}$ & Milk & Fat Test & $\begin{array}{c}\text { Total } \\
\text { Butterfat }\end{array}$ & $\begin{array}{l}\text { Value of Fat } \\
\text { per pound }\end{array}$ & $\begin{array}{l}\text { Total Value } \\
\text { of Fat }\end{array}$ \\
\hline 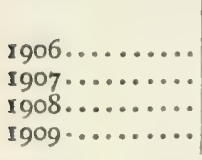 & $\begin{array}{l}239 \\
287 \\
254 \\
272\end{array}$ & $\begin{array}{l}\text { lbs. } \\
5336 \\
5467 \\
6007 \\
6170\end{array}$ & $\begin{array}{l}\text { per ct. } \\
4.04 \\
4.02 \\
4.21 \\
4.28\end{array}$ & $\begin{array}{c}\text { lbs. } \\
215.0 \\
219.7 \\
252.8 \\
264.5\end{array}$ & $\begin{array}{c}\text { Cents } \\
23.3 \\
29.1 \\
27.3 \\
31.2\end{array}$ & $\begin{array}{c}\text { Dollars } \\
50.27 \\
63.85 \\
68.99 \\
82.43\end{array}$ \\
\hline
\end{tabular}

doubled, although this is partially due to an increase in prices.

\section{THE BREEDING ASSOCIATION}

The breeding association is an adjunct of the cow-testing association. It is the logical result of the system of keeping a record of the earnings of each cow. After the dairyman has been shown how he may increase his profits, he will certainly devote his energies to breeding up his herd, unless he lacks enterprise or is prevented by sentiment from changing the members of his herd.

In some communities the functions of breeding and testing of cows are performed by one association. In others, there are two separate associations. At Ashland, Wis., the Commercial Club comprised of business men, purchased a number of bulls, which were placed in nearby sections of the country. The farmers pay a fee for the service of the sire, half of which is retained by the farmer who keeps and cares for the sire and the other half is paid to the club. ${ }^{1}$ In the association at Milaca, Minn., expenses are met by the issue of stock. Each member takes shares according to the number of cows he owns. ${ }^{2}$ In other associations ex-

'Hoard's Dairyman, Dec. 26, I9I3, p. 643.

sIbid. 
Newaygo County, Mich., Daiky Testing Association

\begin{tabular}{c|c|c|c|c|c|c|c}
\hline $\begin{array}{c}\text { Cost } \\
\text { of } \\
\text { Roughage }\end{array}$ & $\begin{array}{c}\text { Cost of } \\
\text { Grain }\end{array}$ & $\begin{array}{c}\text { Total Cost } \\
\text { of } \\
\text { Feed }\end{array}$ & Profit & $\begin{array}{c}\text { Returns for } \\
\text { \$1 Expended } \\
\text { in Feed }\end{array}$ & $\begin{array}{c}\text { Feed Cost of } \\
\text { 1 pound } \\
\text { Butterfat }\end{array}$ & $\begin{array}{c}\text { Feed Cost of } \\
\text { 100 Pounds } \\
\text { Milk }\end{array}$ \\
\cline { 1 - 2 } Dollars & Dolls. & Dollars & Dolls. & Dollars & Cents & Cents \\
20.92 & 8.36 & 29.28 & 20.99 & $\mathbf{1 . 7 2}$ & $\mathbf{1 3 . 6}$ & 55 \\
24.88 & 11.54 & 36.42 & 27.43 & $\mathbf{1 . 7 5}$ & $\mathbf{1 6 . 6}$ & 67 \\
25.60 & 14.07 & 39.66 & 29.33 & $\mathbf{1 . 7 4}$ & $\mathbf{1 5 . 7}$ & 66 \\
27.04 & 14.95 & 41.99 & 40.44 & $\mathbf{1 . 9 6}$ & 15.9 & 68 \\
\hline
\end{tabular}

penses are defrayed by assessments. An important feature of breeding is the acquisition of unrelated sires and the placing of these in sections of the district covered by the association. At the expiration of two years sires are changed from one section to another to secure the best results.

The following constitution and by-laws ${ }^{1}$ for a dairy cattle breeding association are proposed by A. J. McGuire, superintendent of the Minnesota Northeast Experiment Farm, Grand Rapids, Minn. :

\section{CONSTITUTION}

The name of this association shall be —_ farmers' Cooperative Dairy Breeding Association.

The purpose of the association shall be the purchasing, distributing, and maintenance of pure-bred dairy sires of one particular brecd, said breed to be decided upon by a majority of members of the association.

The motto of the association shall be: " 300 pounds of butter per cow annually."

The members of the association shall be farmers who sign the constitution and by-laws of the association.

The officers of the association shall consist of a president, vice-president, secretary, and treasurer and they shall be elected

1 Op. cit., p. 462. 
annually by the members of the association. The duties of the officers of the association shall be the business of the association; purchasing of sires, distribution of same, keeping of records and auditing the accounts.

The expenses of the association, purchasing and maintenance of sire, etc., shall be met by a special cash assessment on each member of the association, this assessment to be determined by the members of the association.

BY-LAWS

I. The breed of dairy sires of the association shall be the breed.

2. No sire shall be purchased under six months of age, or used for service under 12 months of age or for more than onehalf the service required of a mature sire under two years of age.

3. Sires purchased shall not be closely related.

4. One sire shall be purchased for approximately every seventy cows of the association.

5. The association shall be divided into sections, one section for each sire purchased, said section to be designated by number, as section I, section 2, etc.

6. The members of each association section shall be determined by the number of cows, approximately seventy cows constituting a section.

7. The members of each respective section shall be members living nearest together or most conveniently associated.

8. One sire shall be placed with each section, the farmer who is to have charge of sire to be selected by members of the section.

9. The farmer who has charge of a sire must provide comfortable and sanitary quarters. He must not allow the sire to run with the herd, and he must keep the sire in clean and thrifty condition.

I0. For keep of sire the farmer shall be paid \$_ per year.

II. At the expiration of two years, sires shall be exchanged 
from one section to another, sire in section $x$ going to section 2 , sire in section 2 to section 3 , etc. This exchange shall be made every two years. Inbreeding shall not be practiced.

I2. The loss of a sire in any section through death or other causes shall be made good by the purchase of a pure-bred sire of the same breed by the association.

I3. All receipts from sale of sires or breeding service to nonmembers shall be turned in to the association and credited to the sinking fund.

I4. Breeding service to non-members shall be \$-

I5. Farmers in charge of sires shall keep record of all services and report same to secretary at the end of the year.

I6. All members shall report to the secretary at the end of the year calves born, of either sex, sired by the association sire.

I7. The secretary of the association shall hold all papers of registration, keep record of placement of sires in the different sections and their exchange, and keep memorandum of all calves of either sex born in the association.

Two plans of breeding may be followed. The association may agree to secure sires of several of the good dairy breeds and to change these from time to time. In Wisconsin a few associations follow this plan, but most of them in the State decide upon a particular dairy breed by a majority vote and develop the pure-bred dairy cow. In both plans the native stock, which consists of general-purpose cows or scrub cattle, is retained and improved by the infusion of a good dairy strain through the male.

Marvelous possibilities to increase the country's food supply are resident in the principle of breeding. According to the last census, the average production of butter-fat per cow in the United States is 145 pounds. In a census of cows in dairy states taken by W. D. Hoard the average is I 58 pounds. This is considerably lower than the average production of butter per cow in Denmark, which in 1908 
was 224 pounds. In Denmark scientific breeding has been carried on for some time, ${ }^{1}$ and the results show that the average production of butter per cow in 1908 was twice as much as it was in $1884{ }^{2}$ H. E. Alvord writes: " ${ }^{3}$ "The good dairy cow has now been so long bred to a special purpose that instead of the former short milking period, almost limited to the pasture season, it yields a comparatively even flow of milk during ten or eleven months in every twelve, and if desired the herd produces as much in winter as in summer. Whole herds average 300 to $35^{\circ}$ pounds of butter a year." C. L. Peck, in Hoard's Dairyman of Dec. 26. I9I3, says: "There are now in America seventy Jersey cows with records from 7 IO to $I, I 76$ pounds of butter and averaging over 12,000 pounds of milk per annum, enough in number to supply a Jersey bull, son or grandson to every Jersey breeder in the United States and with a liberal sprinkling of daughters and granddaughters within five years from this time. Eurotas, whose production of 778 pounds of butter in one year gave her the championship of the world of her time, and which was considered a remarkable event in her day, now has scores of her own breed and hundreds of the several dairy breeds supporting her record." The same writer gives the record of Eminent Bess, a Jersey cow, at I,I32 pounds of butter for the year; and of Lily of Willowmoor, an Ayrshire, at $\mathrm{I}, 046$ pounds of butter. The record for butter fat up to the present belongs to Finderne Pricie Johanna Rue, a Holstein-Friesian cow, owned by the Somerset Holstein Breeders' Co., New Jersey. This cow produced I, I76.47

${ }^{1}$ Vide, Bulletin I29, Bureau of Animal Industry, U. S. Department of Agriculture.

${ }^{2}$ Vide, Circular I79, Bureau of Animal Industry, U. S. Department of Agriculture.

${ }^{3}$ Agricultural Yearbook for 1889, p. 392. 
pounds of butter fat during the past year. ${ }^{1}$ Many cows of the Jersey, Guernsey, Ayrshire, Holstein and Shorthorn breeds are producing from 500 to 600 pounds of butter a year. The record for butter of thirty years ago has been exceeded by over 350 pounds. This has been accomplished by breeding. What could be accomplished if every farmer in the United States would serve his cows with pure-bred bulls? In I9I4 the U. S. Department of Agriculture estimated the number of milch cows in the United States to be $20,737,000$. It is not beyond the realm of possibility to increase the average yield of cows to 300 pounds of butter. This would mean, however, an increase of over I 40 pounds of butter per cow. If all the butter fat of this increase were converted into butter and valued at 20 cents a pound, which is considerably less than the present yearly average butter price, it would add a gross income of over $\$ 580$,000,000 to the dairy interests of the United States. If the average production per cow could be raised to 300 pounds of butter, the total value of dairy products in the United States, estimated in terms of butter at 20 cents a pound, would be over $\$ 1,244,000,000$. The great importance of these coöperative cow-testing and breeding associations is therefore apparent.

\section{COÖPERATIVE BUYING ASSOCIATION}

These associations are formed for the purpose of buying feed and fertilizers in car-load lots at reduced prices. In some places a special association is formed to buy coöperatively and transact the business. In Gallia County, Ohio, the farmers organized a cow-testing association and also a buying association. ${ }^{2}$ The usual way, however, is to buy

1 The test was supervised by the New Jersey Agricultural College. Vide, Hoard's Dairyman, July 2d, 1915, p. 818.

${ }^{2}$ Hoard's Dairyman, Dec. 16, 1914, p. 746. 
through a coöperative association already established and organized primarily to serve some other purpose, such as the testing of cows or the manufacture of butter. At Coopersville, Mich., coöperative buying is sometimes done by the coöperative creamery association. There was a time when the farmers could not get cottonseed meal, oil meal, and gluten feed at desired prices and in suitable quantities from the dealers of the town. Car-load lots of feed were therefore secured through the creamery association. The effect of this was to cause dealers to sell on terms which were just as satisfactory to the farmers as they could get by buying coöperatively. Coöperative buying in this instance was therefore discontinted. ${ }^{1}$ Important savings can be made by buying in large lots, but if the coöperative organization exists, to be used whenever satisfactory terms are not secured through dealers and thus keep prices down, it may be better in many instances to allow professional business men to do the buying so as to enable the dairy farmer to devote all of his energies to matters of production.

\section{BUSINESS ORGANIZATION OF THE CREAMERY}

The first creameries in the United States were practically all organized on the coöperative plan. Since then other forms of organization have increased faster than the coöperative form.

The organization of the butter factory at Hatfield, Massachusetts, established in I8So, is typical of the forms of organization of all butter and cheese factories during the early days of the factory system. An account ${ }^{2}$ of the plan of organization of the Hatfield factory will therefore give an idea of the earliest coöperation in the dairy industry of

${ }^{1} V$ ide, Report of the Michigan Dairy Association for 1909, p. 302.

" Report of the Maine Board of Agriculture for I88I, p. I3. 
the United States. The amount of capital necessary to erect buildings and equip them properly was secured by the issue of stock. The stock was divided into small shares of $\$ 25$ each and distributed chiefly among the prospective patrons of the factory with a view to create a general interest in the success of the establishment. A dividend of 6 per cent was guaranteed to the shareholder. The stockholders elected five directors, who were charged with the management of the factory. The directors elected one of their number as presiclent and another as superintendent and treasurer. ${ }^{1} \quad 1$ butter-maker was employed to make the butter at $3 \frac{1}{2}$ cents per pound. The butter-maker in this case assumed all expenses, including the interest on the stock. In other cases the butter-maker was given a salary. The net earnings, after paying all expenses, including the salary, interest on the stock, and in some cases a depreciation charge sufficient to replace equipment, were apportioned among the patrons according to the amount of cream furnished. In the earlier factories the raw material was in the form of milk, and the division of the earnings was therefore on the basis of milk furnished.

This type of coöperative creamery has in many instances continued to the present. James Ford ${ }^{2}$ says concerning the Hampton Coöperative Creamery Association of East Hampton, Massachusetts, founded in I88I, that " in I9I I it had 43 shareholders who held $\$ 2,500$ of capital stock in twenty-five-dollar shares. They own $\$ 3,000$ worth of real estate free from mortgage and have a reserve of $\$ 4,623$. Sales for the year I9Io amounted to \$86,9I4, from the profits of which 6 per cent interest on shares was paid to

${ }^{1}$ This organization was similar to that of the early cheese factories. Vide, Report of the Transactions of the N. Y. State Agricultural Society for 1863 , p. 197.

${ }^{2}$ James Ford, Coöperation in New England, p. I38. 
members, the balance going to all patrons, whether members or not, according to the amount of butter fat in the milk they sold to the creamery. An average of 40 cents per pound was paid patrons for butter fat, a sum equaled by only one other of the reporting coöperative creameries of New England."

In I9I 3 the U. S. Department of Agriculture ${ }^{1}$ reports a total of 2,I65 coöperative creameries distributed throughout the country, as follows:

\begin{tabular}{|c|c|c|c|c|}
\hline Arkansas .......... & I & Maryland ........ & 3 & Oklahoma ........ \\
\hline Arizona............ & $\mathbf{I}$ & Massachusetts..... & 8 & Oregon............ \\
\hline California .......... & 36 & Michigan......... & 105 & Pennsylvania ...... \\
\hline Colorado........... & 14 & Minnesota........ & 632 & South Carolina .... \\
\hline Connecticut........ & I5 & Mississippi ....... & I & South Dakota..... \\
\hline Delaware.......... & 2 & Missouri ........ & 16 & Tennessee.......... \\
\hline Georgia........... & 2 & Montana.......... & 9 & Texas.............. \\
\hline Idaho ............. & 3 & Nebraska......... & 14 & Utah................... \\
\hline Illinois ........... & 62 & Nevada........... & 3 & Vermont.......... \\
\hline Indiana............ & 67 & New Hampshire .. & 6 & Virginia .......... \\
\hline Iowa............. & 308 & New York........ & 120 & Washington....... \\
\hline Kansas............. & 7 & North Carolina.... & 2 & West Virginia ..... \\
\hline Kentucky ......... & 14 & North Dakota..... & 43 & Wisconsin ........ \\
\hline Maine ............ & 7 & Ohio $\ldots . . . \cdots$. & 32 & Wyoming...$\cdots$ \\
\hline
\end{tabular}

Some of these creameries are organized and run on a purely coöperative plan; the organization of others is technically that of a joint stock company, but in spirit is cooperative. In the former type of organization the creamery association is composed of patrons who own the creamery building and machinery and who are paid the entire net earnings of the enterprise. Dividends on the stock are limited to the current interest rate, in many instances to 6 per cent. Patrons are paid in proportion to the butter fat supplied as indicated by the Babcock test. As long as

${ }^{1}$ Agricultural Ycarbook, I9I3, p. 244. 
the return on capital is limited to the current rate of interest and all of the net earnings are divided among the patrons whether or not they own stock, the enterprise is run on the principle of complete coöperation. H. C. Adams, in his report for 1900 as Dairy and Food Commissioner of IVisconsin, says that a great number of creameries in the state " are coöperative in part, the manager of the creamery owning it, making and selling the product, deducting a fixed charge for making with other expenses, and dividing the remainder among the patrons." Another feature that distinguishes associations that are purely coöperative from those that are coöperative in part is the method of electing their directors. Each stockholder may be given one vote, or voting may be exercised according to the number of shares owned. The latter principle may again be modified by limiting the number of shares voted. ${ }^{1}$

The following constitution, ${ }^{2}$ drafted by the Wisconsin State Board of Public Affairs, and slightly modified by the editors of Hoard's Dairyman, probably represents the best form of organization for coöperative creameries in use at the present time:

Organizing a Coöperative Creamery or Cheese Factory FORMS OF AGREEMENT, BY-LAWS, ETC.

\section{First Meeting}

A temporary chairman and secretary should be elected; the advisability of starting a creamery or cheese factory, and the most desirable location should be discussed, and the value of each share should be decided upon.

If it be deemed advisable to form an association, a committee should be elected to canvass the surrounding territory to ascertain if there is a sufficient number of stockholders and cows to warrant an association.

${ }^{1}$ James Ford, Coöperation in New England, pp. I37, I43.

2 Furnished by Hoard's Dairyman. 


\section{Organization Agreement}

(To be used at first meeting)

We, the undersigned citizens of - , State of $\longrightarrow$, do hereby agree to form ourselves into an association for the purpose of - and to take the number of shares of stock, at the par value, to wit: —— dollars each, and furnish the $\left\{\begin{array}{c}\text { milk } \\ \text { cream }\end{array}\right\}$ from the number of cows set opposite our names.

Provided, however, that if cows and stockholders are not secured before —_ I9-, this agreement shall be null and void.

Name-Chares-Cows

ARTICLES OF INCORPORATION

(These must be in accord with the laws of the state in which the association is formed.)

Suggested By-laws for Coöperative Creamery or Cheese Factory Article I

Name and Object

Sectron I. The name of this association shall be the Coöperative

SECTION 2. The purpose of this association shall be to carry on the manufacture of butter (or cheese) and other dairy products. Also to purchase, use and hold real and personal estate necessary for the transaction of the business of the association.

Article 2

Corporate Powers

Section I. The corporate powers of this association shall be vested in a board of directors, except such powers as are or may be reserved by statute or by these rules and regulations to be exercised by the association as a whole. 
Article 3

\section{Membership}

Section $x$. The association shall include any person who has accepted and regularly enrolled on the company's books as a member.

Section 2. Each member shall be entitled to one rote only.

Section 3. New members may be admitted by a majority vote of the association. Members shall be permitted to withdraw only as follows: The member desiring to withdraw shall give at least one month's notice of his application thereof. Such application shall only be allowed on a vote of two-thirds of all the members present and voting at any meeting.

Section 4. No proxy voting shall be allowed, but stockholders may vote by mail in any regularly called general or special meeting of the stockholders. A written vote received by mail from any absent stockholder and signed by him may be read at such meeting and shall be equivalent to a vote of each of the stockholders so signed; provided that he has been previously notified in writing of the exact motion or resolution upon which such a vote is taken, and a copy of the same is forwarded with and attached to the votes so mailed by him.

Section 5. The acceptance by a member of a stock certificate shall constitute a contract between such member and the company and assent of such stockholder to these by-laws and to amendments legally adopted.

Section 6. Each member of the company becomes subject to, accepts and agrees to abide by these rules and regulations and all future amendments enacted by the company.

\section{Article 4}

Capital Stock

Section I. The capital stock of this association shall be thousand dollars which shall be divided into hundred shares of - dollars each, which shall be paid in at such times, and in such amounts as the board of directors may determine and may be paid either in cash, property, labor or securities, as the board of directors may determine. 
Section 2. When a note is given the association for stock, it may be paid by a certain percentage deducted from each pound of butterfat or each one hundred pounds of milk delivered by each such stockholder. Provided, however, that no certificate shall be issued nor any interest paid on any share of stock until it is fully paid.

It is further provided that all stock may be retired as fast as money accruing from the sinking fund will allow. All stockholders shall receive six (6) per cent interest on their stock until it is retired by the association.

Section 3. After all stock has been retired, each patron contributing to this factory all his milk or cream that he has for sale becomes a member of, and has a right to vote in, this association.

Section 4. Shares of stock shall be non-assessable and non-transferable except as provided in Section 5 of this article.

SECTION 5. All shares must, before issue, be registered on the books of the association, and when surrendered for transfer new ones must be issued in the name of the purchaser, who by acceptance thereof agrees to all the by-laws and rules of the association, including also all amendments that may be legally adopted, and thereby shall become a member of the company. No shares can be transferred until all claims of this company against the owner of such shares have been paid.

Section 6. If any member of the association desires to dispose of his share or shares, he shall first offer to sell same to the company at par value; if the company declines to purchase, the member may find a purchaser acceptable to the company and have same transferred to said purchaser on the books of the company in accordance with the rules. If a member removes from the territory and ceases to be a patron of the association and establishes a residence elsewhere, the board of directors shall purchase the share or shares owned by the said non-resident member.

Sections five (5) and six (6) of this article shall be printed on each and every certificate of stock issued by the company. 


\section{Article 5}

The duties of the respective officers shall be as follows:

\section{President}

Section r. The President shall preside at all meetings of the association. He shall have power to call special meetings of the association whenever, in his judgment, the business of the association shall require it. He shall, also, upon a written request of ten per cent of the stockholders or three members of the board of directors, call a special meeting.

\section{Vice-President}

Section 2. The Vice-President shall perform the duties of the president when the latter is absent or unable to perform the duties of his office.

\section{Secretary}

Section 3. The secretary shall keep a record of all the meetings of the association and make and sign all orders upon the treasurer and pay over to the treasurer all money which comes into his possession, taking the treasurer's receipt therefor. The secretary shall make a report to the annual meeting of the association, setting forth in detail the gross amount of milk and cream receipts and the net amount of receipts from products sold and all other receipts, the amount paid out for running expenses, the sums paid out for milk and cream, and all other matters pertaining to the business of the association. A like statement shall be made each month and posted conspicuously in the creamery building at the time of the division of the prerious month's receipts aforesaid. The secretary shall give bonds in the sum of dollars, same to be approved by the board of directors.

\section{Treasurer}

Section 4. The treasurer shall receive and receipt for all moneys belonging to the association, and pay out only upon orders signed by the secretary. The treasurer shall give bonds in the sum of - dollars, same to be approved by the board of directors. 


\section{Article 6}

\section{The Board of Directors}

Section I. The board of directors who are elected at the annual meeting for one year shall attend to the general affairs of the association and appoint such agents or officers as in their judgment the interests of the association require. They shall keep or cause to be kept a correct account of all the milk furnished by stockholders or patrons and a correct account of sales. They shall establish prices and have full power of the business of the association, and in all cases pursue such measures as in their judgment will tend to the best interests of the association. They shall make a full report of their doings and a full statement of the business at each regular meeting or whenever called on to do so by the vote of the stockholders.

SECTION 2. The board of directors shall appoint one of their members sales manager, who shall with the butter or cheesemaker have full control of the sale of all products and the buying of all supplies; but shall confer with the directors from time to time.

Section 3. The directors shall have regular monthly meetings on the last Monday of each month.

\section{Quorum}

Section 4. A majority of the directors shall constitute a quorum for the transaction of all business at meetings of the directors.

\section{Article 7 \\ Educational Committee}

Section I. The directors shall appoint an educational committee of three stockholders to periodically place before the people in printed matter, public meetings or otherwise, the benefits of coöperation.

\section{Article 8}

Buttermaker or Operator

Section I. The board of directors shall secure the services 
of a competent operator and pay him the salary they deem sufficient.

Said operator shall make out and deliver to the secretary on or before the tenth of each month a true statement of the number of pounds of cream delivered by each patron for the preceding month, and the total yield of the factory for the said month, and the number of pounds of butter or cheese, if any, drawn out by each patron.

Section 2. It shall also be the duty of the operator to take the necessary samples and make the tests of each patron's milk or cream in such manner as required by law or prescribed by the board of directors and to perform such other duties as required by the board of directors.

Section 3. The building shall be kept in a clean and sanitary condition by the operator. Smoking and chewing of tobacco shall be prohibited in the creamery. The buttermaker shall enforce this rule strictly.

\section{Article 9}

\section{Milk Furnished}

Section I. The several members shall furnish all the milk from all the cows subscribed by each, all the milk to be sound, fresh, unadulterated, pure and unskimmed, and the patrons of the association, not members, may by agreement with the board of directors, furnish such amounts of milk as may be so agreed upon. The association shall receive all such milk so furnished, manufacture the same into butter, cheese, or both, and sell and receive all moneys for the product.

SeCtion 2. Any member or patron of the association found skimming, watering or in any manner adulterating his milk offered at the factory shall forfeit to the association as follows: For the first offense ten dollars; for the second offense, twentyfive dollars; for the third offense, he or she shall forfeit all interest in the association and also all claims for milk theretofore delivered to the association. But no such forfeiture shall be adjudged without first affording to the member or patron charged with having so skimmed, watered or aduterated his 
milk, full opportunity to defend himself or herself from such charge.

Any member who sends in any bloody or impure milk, or any milk from any cow within four days before calving, shall, if convicted of having done so knowingly, forfeit as prescribed above.

Section 3. During the interval between the twentieth of May and the twentieth of September of each year, all milk shall be delivered at the factory as early at least as —__ in the morning and during the remainder portion of the year as early as —-

Section 4. Members and patrons furnishing whole milk may take from the separator or the tank at the creamery of the quantity of milk (in pounds or quantity) delivered at the creamery by them on that day. Any member taking therefrom more than such amount shall forfeit to the association the sum of five dollars for each such offense.

Section 5. Any member, without reasons satisfactory therefor to the association, refusing to deliver at the creamery the milk agreed to be there delivered, shall forfeit all interest in the product on hand and stock in the association.

Section 6. No milk shall be received or business of any kind transacted on Sundays.

SeCtion 7. Patrons of the creamery not living on a cream route shall be allowed such compensation for hauling their cream to the factory as the board of directors may think proper. But patrons living on a cream route shall receive no compensation for delivering their cream.

\section{Article IO}

SECTION I. If a competitor raises the price of butterfat above its market value, any stockholder shall have a right to sell his mill: or cream to such competitor-provided that the cream is first weighed and tested at the factory, and one cent per pound of butterfat is paid to the association for maintaining the creamery. 
Article II

\section{Division of Profits}

Section I. The directors, subject to revision by the association at any general or special meeting, shall apportion the earnings by first paying interest on the paid-up capital stock not exceeding $6 \%$ per annum. Then set aside not less than ro\% of the net profits for a reserve fund until an amount has accumulated in said reserve fund equal to $30 \%$ of the paidup capital stock, and $5 \%$ of the net earnings for an educational fund to be used in teaching coöperation, and the remainder of said net profit by uniform dividend proportional to the amount of raw material delivered by patrons.

Section 2. All expenses of repairing, insurance, taxes, permanent improvement to or upon the factory, and interest upon the indebtedness shall be paid out of the reserve fund.

\section{Article I2}

\section{Reports}

Section $\mathrm{x}$. The secretary shall, at the annual meeting, give the report of the business done by the company during the last fiscal year. He shall make out further reports on the request of the board of directors.

SECTION 2. The association shall annually on or before the first day of — of each year make such reports as are required by law.

\section{Article I3}

\section{Annual and Special Meetings}

Section I. The annual meeting shall be held on the of the month of - at $2.00 \mathrm{p}$. m. for the election of officers and for the transaction of such other business as may properly come before the meeting.

Section 2. Special meetings of the company shall be called as provided in Article 5, Section I. 
Quorum

SeCtion 3. members shall constitute a quorum for the transaction of business.

\section{Initiative and Referendum}

Section 4. Ten per cent of the members shall have the right to initiate any measure or policy that they see fit and when such member or members shall present a desired measure to the board in writing, the latter shall refer the same to the stockholders for final action.

\section{Article 14 \\ Amendments to By-Laws}

Section I. These by-laws may be altered or amended by a two-thirds vote of the members present at any regular annual meeting or any special meeting called for that purpose. In the latter case ten days' notice thereof shall have been given to all the members previous to the time of voting thereon.

Section 2. Whenever in the opinion of the board of directors a change in the rules and regulations is necessary, they shall have power to initiate such change and refer it to the shareholders for final action.

\section{Article 15}

Order of Business

I. Call to order.

2. Roll call of officers.

3. Reading minutes of last meeting.

4. Report of officers.

5. Reports of committees.

6. Reports of education committee.

7. Reports of managers.

8. Communications and bills.

9. Grievances and complaints.

Io. Consideration of reports.

II. Election of officers.

I2. Filling vacancies. 
13. Appointing committees.

14. Unfinished business.

15. New business.

I6. Good of the company.

I7. Signing of minutes.

18. Adjournments.

Attention is especially invited to article 4, sections 2 and 3 , which aim to keep the character of the association truly coöperative; to article 7 , section $I$, which aims to educate the patrons and keep the coöperative interest alive; and to article II, which precludes the tendency to declare high dividends, provides for the distribution of the profits among the producers, and keeps the finances sound by the establishment of a reserve fund.

\section{TABLE IV}

The Character of Ownership and the Value of Products of the Total Number of Butter, Cheese, and Condensed-Milk Establishments in the United States

\begin{tabular}{|c|c|c|c|c|c|}
\hline \multirow{2}{*}{$\begin{array}{l}\text { Character } \\
\text { of } \\
\text { Ownership }\end{array}$} & \multicolumn{3}{|c|}{$\begin{array}{l}\text { No. of } \\
\text { Establishments }\end{array}$} & \multicolumn{2}{|c|}{ Value of Products } \\
\hline & 1909 & I904 & 1899 & 1909 & 1904 \\
\hline Total. & 8479 & 8926 & 9242 & $\$ 274,557,718$ & $\$ 168,182,789$ \\
\hline Individual. ......... & 3370 & 3817 & 4509 & $61,43^{2,34 I}$ & $43,919,439$ \\
\hline Firm...$\ldots \ldots \ldots \ldots$ & 1021 & 1297 & 1340 & $26,997,945$ & $22,653,536$ \\
\hline Corporation........... & 1313 & 1385 & 1628 & I $13,493,555$ & $61,309,538$ \\
\hline Cöoperative.......... & 2775 & 2433 & $x 765^{1}$ & $72,633,877$ & $40,300,276$ \\
\hline Per cent of total.. & 100.0 & 100.0 & 100.0 & 100.0 & 100.0 \\
\hline Individual ........... & 39.7 & 42.8 & 48.8 & 224 & 26.1 \\
\hline Firm $\ldots \ldots \ldots \ldots \ldots$ & $\mathrm{I} 2.0$ & I 4.5 & 14.5 & 9.8 & 13.5 \\
\hline Corporation ......... & I5.5 & 15.5 & 17.6 & $4 \mathrm{I} \cdot 3$ & 36.5 \\
\hline Coöperative. ......... & 32.7 & $27 \cdot 3$ & 19.1 & 26.5 & 24.0 \\
\hline
\end{tabular}

(From U. S. Census).

${ }^{1}$ Listed as miscellaneous in table, but characterized as coöperative in descriptive part. Vide, Census, I900, vol. ix, p. 439. 
It is seen in Table no. 4 that the total number of establishments owned by individuals, firms, and corporations, is considerably in excess of the number organized on the cooperative plan. Of the total number of establishments at the time of the last census, 67.2 per cent were under capitalist ownership and 32.7 per cent under coöperative ownership. All of the three forms of capitalist ownership have decreased since I900, while the number of coöperative

\section{TABLE V}

The Distribution of the Different Forms of Organizations of Butter, Cheese, and Condensed-Milk Establishments among the Principal Dairy States

\begin{tabular}{|c|c|c|c|c|c|c|c|c|}
\hline \multirow{2}{*}{ State } & \multicolumn{2}{|c|}{ Individuals } & \multicolumn{2}{|c|}{ Firms } & \multicolumn{2}{|c|}{ Corporations } & \multicolumn{2}{|c|}{$\begin{array}{l}\text { Coöperative } \\
\text { Associations }\end{array}$} \\
\hline & 1909 & 1899 & 1909 & I 899 & 1909 & I899 & 1909 & โ 899 \\
\hline United States....... & 3370 & 4509 & 1021 & I 340 & 1313 & 1628 & 2775 & 1765 \\
\hline California......... & 52 & 80 & 28 & 29 & 52 & 62 & 26 & 7 \\
\hline Illinois ....... & 90 & 224 & 43 & 96 & 84 & 127 & 78 & 80 \\
\hline Iowa $\ldots . . . . . . . .$. & 105 & 328 & $5 \mathrm{I}$ & 133 & 58 & 187 & 298 & 259 \\
\hline Michigan .......... & I3 & I 2 I & 84 & 37 & 118 & 57 & 102 & $7 \mathrm{I}$ \\
\hline Minnesota....... & 150 & II 6 & 33 & 50 & 46 & 92 & 555 & 338 \\
\hline New York........ & 893 & 1274 & 239 & 280 & 208 & 195 & 212 & 159 \\
\hline Obio............... & 87 & 232 & 53 & 97 & 72 & 63 & 113 & 87 \\
\hline Pennsylvania ....... & 276 & 394 & 102 & 153 & 52 & 83 & 106 & II9 \\
\hline Vermont ........... & 50 & 96 & 14 & 23 & 22 & 85 & 100 & $5^{x}$ \\
\hline Washington........ & 27 & 32 & 12 & 12 & 40 & ro & 18 & 6 \\
\hline Wisconsin......... & 1242 & 1118 & 236 & 234 & $28_{3}$ & 289 & 869 & 377 \\
\hline
\end{tabular}

(From U. S. Census).

establishments has increased. The number of establishments apart from their output, however, does not give a correct statement of the changes of these forms of organization. From I904 to I909 the percentage of the total output of establishments owned by both individuals and firms lias decreased, and that of coöperative establishments 
has increased only slightly, while that of establishments ınder corporate ownership has increased from 36.5 per cent to 4 I.3 per cent. It appears, therefore, that the establishments owned by individuals and firms are giving way to the corporate form of organization. It is through this form of organization that practically all of the concentration in the dairy industry is effected. It is to be expected, therefore, that this form of organization will increase

TABLE VI

The Value of Products of the Different forms of Organization of Butter, Cheese, and Condensed-Milk Establishments

in the United States During 1909

\begin{tabular}{|c|c|c|c|c|}
\hline State & Individuals & Firms & Corporations & $\begin{array}{l}\text { Coöperative } \\
\text { Associations }\end{array}$ \\
\hline United States...... & $\$ 61,432,321$ & $\$ 26,997,945$ & $\$ 113,493,555$ & $\$ 72,633,877$ \\
\hline California......... & $2,263,798$ & 994,872 & $7,356,944$ & $2,145,056$ \\
\hline Illinois .......... & $1,574,475$ & $1,384,527$ & I $3,2 \mathrm{CO}, 456$ & $1,638,820$ \\
\hline Iowa.......... & $3,371,872$ & $2,239,808$ & $7,737,198$ & $12,500,988$ \\
\hline Michigan ..... & $2,986,902$ & $2,512,295$ & $5,531,195$ & $3,257,107$ \\
\hline Minnesota ....... & $4,592,276$ & 946,236 & $3,957,93 \mathrm{I}$ & $15,791,019$ \\
\hline New York .. & $12,793,485$ & $5,891,396$ & $18,521,5 \mathrm{C} 8$ & $5,251,956$ \\
\hline Ohio ............. & $\mathrm{I}, 592,13 \mathrm{I}$ & $1,144,155$ & $5,874,5$ I 4 & $1,078,870$ \\
\hline Pennsylvania........ & $4,570,716$ & $2,539,499$ & $4,105,119$ & $2,328,73 \mathbf{I}$ \\
\hline Vermont ........... & I, 850,284 & 596,280 & $2,953,937$ & $2,7 \mathbf{I} 1,738$ \\
\hline Washington..... & 787,342 & 510,173 & $5,333,026$ & 640,506 \\
\hline Wisconsin ........ & $19,332,700$ & $5,056,410$ & $10,438,592$ & $19,015,547$ \\
\hline
\end{tabular}

(From the U. S. Census).

rapidly in its output, but slowly, if at all, in the number of establishments. The coöperative establishments show greater permanency than those owned by individuals and firms. There was a very considerable increase in the number of coöperative establishments and a slight increase in the percentage of the total value of products.

The relative importance of the different forms of organization in the various states in I9lo is shown in Table no. 6 . 
During the decade preceding r 909 the number of cooperative establishments increased in all of the principal dairy states except Illinois, which shows a decrease of 2 , and Pennsylvania, which shows a decrease of I3. In 1900 , 60 per cent of the total number of establishments in Minnesota were organized on the coöperative basis. In I9ro this state had 70.8 per cent of its establishments under cooperative ownership. Wisconsin also shows a large increase. As shown by the value of products, coöperation is most important in Wisconsin, Minnesota, and Iowa. In Wisconsin, however, the output of establishments owned by individuals is a little larger than that of coöperative associations. The corporate form of organization has more than doubled in Michigan; in Washington it has increased by 30 ; and in New York and Ohio the increase was 13 and I I establishments respectively. In Illinois there was a decrease of 43 corporate establishments, and in Iowa a decrease of I29. It is in these states particularly that the large plants known as "centralizers" have developed. They are especially important in Illinois, as is shown by the value of products of the corporate form of ownership. Coöperation in Illinois seems to be overwhelmed by the corporation, but in Iowa it is still the most important form. The corporate form is most numerous in Wisconsin, but its largest output occurs in New York. New York also leads in the number of establishments owned by firms, as well as in the value of products for this form of ownership. Wisconsin leads in both the number of establishments owned by individuals and the value of their products. The expansion of corporations and coöperative associations is going on at the expense of the establishments owned by individuals and by firms, and the struggle for supremacy lies between the corporation and the coöperative association. The value of products of corporations is already 
almost twice as large as that of coöperative associations; yet the number of establishments of the latter type is increasing even in the states of New York and Vermont, where the demand for fresh milk is undermining the production of butter and cheese.

The success of coöperation in the dairy industry is largely dependent upon whether or not the people are properly educated as to its benefit and limitations and are skilled in the art of doing business. A seemingly unimportant factor that will determine whether or not a coöperative association will lose its coöperative character, is the failure to adopt a constitution that prohibits voting by shares and declaring high dividends on stock. Sometimes the management fails to build up a sinking fund, and when business reverses come the concern has nothing to draw upon and the association may be doomed. A clear understanding of the value of coöperation in all the fields of enterprise will contribute very materially to the success of the movement. In succeeding chapters, dealing with the market organization, it is shown that the work of distributing butter performed by the middlemen is a service that requires a great deal of attention and special training. In connection with the cow-testing and breeding associations, it was shown that it is in the fieid of production that coöperation among dairymen can very substantially increase the farmers' income. In view of these facts, it is far better for the farmers first to coöperate in production before attempting to market cooperatively and thus dissipate their energies in the least profitable field. The organization of all coöperative associations within a state into a state coöperative society would be an important achievement. Such an association could well afford to take up the problem of marketing; and if the butter and cheese were handled by a central selling agency at cost, the coöperative associations would probably 
increase their profit very appreciably. Before organizing for the purpose of marketing, however, it would be much more fruitful to organize a central body that would look toward the standardization of the product and the introduction of uniform methods of manufacture in all the establishments, and above all that would supervise local associations whose object it is to increase the yield of the cow. Such a course would not only be the most profitable one, but also the easiest. Obviously, after a product has been standardized and made of exceptionally good quality, selling it is comparatively easy. 


\section{CHAPTER III}

\section{Geographic Distribution of Butter-Producing Areas}

\section{HISTORIC CHANGES}

THE westward course of the butter belt in the United States is shown in Table no. 7. This table shows that the center of butter production remained in the Middle At-

\section{TABLE VII}

The Amount of Butter Produced in the United States by GeOGRAPHIC DiVISIONS FROM 1850 TO 1910 (Ooo OMITTED)

\begin{tabular}{|c|c|c|c|c|c|c|c|}
\hline $\begin{array}{l}\text { Geographic } \\
\text { Divisions }\end{array}$ & r910 & 1900 & 1890 & 1880 & 1870 & 1860 & $185^{\circ}$ \\
\hline & Pounds & Pounds & Pounds & Pounds & Pounds & Pounds & Pounds \\
\hline $\begin{array}{l}\text { New England..... } \\
\text { Middle Atlantic... }\end{array}$ & $\begin{array}{c}\text { (a) } \\
167,30\end{array}$ & $\begin{array}{r}92,032 \\
233,986\end{array}$ & $\begin{array}{r}77,240 \\
217,703\end{array}$ & $\begin{array}{r}65,934 \\
25073\end{array}$ & $\begin{array}{l}49,662 \\
176,248\end{array}$ & $\begin{array}{r}5 \mathrm{I}, 485 \\
172,465\end{array}$ & $\begin{array}{r}43,924 \\
129,131\end{array}$ \\
\hline E. N. Central. & 424,137 & 403,208 & 327,051 & 240,351 & $\begin{array}{l}110,240 \\
156,138\end{array}$ & $\begin{array}{l}12,403 \\
124,017\end{array}$ & $\begin{array}{l}129,131 \\
70,557\end{array}$ \\
\hline W. N. Central .... & 444,724 & 407,632 & 323,500 & 143,103 & 58,262 & 29,054 & 10,006 \\
\hline South Atlantic..... & (a) & $92,88_{3}$ & 80,414 & 48,703 & 28,575 & $33,94 \mathrm{I}$ & $28, \mathrm{IC}$ \\
\hline E. S. Central...... & (a) & (a) & 84,955 & $5^{1}, 603$ & 27,273 & 32,769 & 26,4 \\
\hline W. S. Central ..... & (a) & 88,856 & 50,347 & 22,605 & 6,789 & 11,362 & \\
\hline Mountain .. & (a) & (a) & 8,748 & 3,205 & 1,348 & 337 & \\
\hline Pacific ..... & 84,780 & 54,653 & 35,456 & $20,09 I_{i}$ & 9,795 & 4,248 & 212 \\
\hline
\end{tabular}

"(a) Cannot be shown separately, as to do so would disclose individual operations." Vide, U. S. Census. Data taken from Statistical Abstract of the United States.

lantic states from I 850 to I 870 , that during the succeeding decade it moved west into the East North Central states and remained there until I890, and that between 1890 and I900 it moved still farther west into the West North Cen30I] 
tral states where, in I909, the product constituted 27.5 per cent of the total amount of butter produced in the United States. In 1899 this geographic division produced 27.3 per cent of the total product while the East North Central division produced 27.0 per cent of the total product. In I 909 the latter division dropped to 26.2 per cent. At the last census therefore the East and West North Central states produced 45 per cent of the total amount of butter produced in the United States. New York for a long time held first place in the production of butter, but in 1909 it ranked eighth, Wisconsin, Iowa, Minnesota, Pennsylvania, Michigan, Ohio, and Illinois, all producing more butter than New York.

\section{TABLE VIII}

The Amount of Butrer Produced in the Largest Dairy STATES FROM I850 TO I9IO

(OOO OMITTED)

\begin{tabular}{|c|c|c|c|c|c|c|c|}
\hline State & rgro & 1900 & 1890 & 1880 & 1870 & 1860 & 1850 \\
\hline & Pounds & Pounds & Pounds & Pounds & Pounds & Pounds & Pounds \\
\hline Wisconsin & 131,085 & 106,552 & 60,355 & 33,842 & 22,473 & 13,611 & 3,633 \\
\hline Iowa. & I 27,26 I & 139,022 & 126,036 & 61,665 & 27,512 & II,953 & 2,171 \\
\hline Minnesota..... & $123,55^{1}$ & 82,363 & 48,677 & 19,244 & 9,522 & 2,957 & 1,100 \\
\hline Pennsylvania ... & 01,642 & III, $35^{8}$ & 96,199 & 80,322 & 60,834 & 58,653 & 30,878 \\
\hline Michigan....... & 85,917 & 67,872 & 52,343 & 38,865 & 24,400 & 15,503 & 7,065 \\
\hline Ohio........... & 81,060 & 87,038 & 81,522 & 69,722 & 50,266 & 48,543 & 34,449 \\
\hline Illinois ......... & $7 x, 180$ & 86,548 & 82,674 & 60,208 & 36,083 & 28,052 & 12,526 \\
\hline New York..... & $69,35^{8}$ & I 15,408 & I 12,727 & 120,878 & 107,147 & 103,097 & 79,766 \\
\hline
\end{tabular}

(From Statistical Abstract of the United States).

As is shown by table no. 8, New York was the largest butter-producing state as late as ISSO. If there were census figures to show the amount of butter produced from the beginning of our national life to 1850 , they would probably place New York state first in the production of 
butter from I80o to I880. After I8So the production of butter in New York declined rapidly until, in I9IO, the amount produced was only a little more than half the product of I880. Between I880 and I890 the state of Iowa increased its production by over a half and remained the largest butter-producing state for two decades. In I9Io the production in Iowa had decreased by about I 2 million pounds and in Wisconsin it had increased by about $25 \mathrm{mil}-$ lion pounds as compared with the previous census amounts. Wisconsin, at the last census, therefore, was the largest butter-producing state. The maximum amount of butter, however, produced by any state as reported during census years, was produced by Iowa in 1900 .

In view of the fact that the states vary greatly in size, the boundary line of the state as the area of production, does not give a correct picture of the distribution of the butter industry. A better idea is obtained by taking the square mile of land surface as the unit of production. When this is done it is seen that Vermont is the greatest butter-producing state in the country. In 1899 Vermont produced over $4 \mathrm{I} / 2$ million pounds of butter to the square mile of land area. In Igog the production per square mile dropped to a little less than 4 million pounds. No state has ever produced an average production per square mile as high as this. The nearest approach to this record was $2 \mathrm{I} / 2$ million pounds which was the average amount per square mile in New York in IS79 and in Iowa in 1899. Vermont has held the record of production per square mile since 1879 . At that time the production per square mile was a little over $2 \mathrm{~T} / 2$ million pounds.

The production of cheese has also moved westward. Cheese production, however, is less scattered than butter production. Cheese manufacture has been transferred almost entirely to the factory and it seems that good-will 
is an impurtant factor in selling the product. This is one reasun why the cheese industry has become largely centered in New York and Wisconsin. These states have been early in the field of cheese production and have used aggressive methods in placing the product on the market. The expert skill in cheese manufacture that has developed among the people of these states is another reason why this industry has become more centered than the manufacture of butter. Other states were under a much greater strain than New York and Wisconsin in meeting the competition of foreign countries which have imported large quantities during the last decade. It may be expected therefore that the tendency toward shifting will be less marked in the cheese industry than in the butter industry. Nevertheless the industry is moving westward as is shown by a statement of the amounts of cheese produced in the leading dairy states from 1850 to 1910.

TABLE IX

The amount of Cheese Produced in the Largest Dairy States FROM I 850 TO 1910

(OOO OMITTED)

\begin{tabular}{|c|c|c|c|c|c|c|c|}
\hline State & 1910 & 1900 & 1890 & 1880 & 1870 & I 860 & $185^{\circ}$ \\
\hline & $\begin{array}{l}\text { Pounds } \\
148,906\end{array}$ & $\begin{array}{r}\text { Pounds } \\
70,384\end{array}$ & $\begin{array}{r}\text { Pounds } \\
54,614\end{array}$ & $\begin{array}{r}\text { Pounds } \\
I 0,535\end{array}$ & $\begin{array}{r}\text { Pounds } \\
3,288\end{array}$ & $\begin{array}{r}\text { Pounds } \\
\text { I, 104 }\end{array}$ & $\begin{array}{r}\text { Pounds } \\
400\end{array}$ \\
\hline New York. & $10_{5}, 5 S_{4}$ & 130,010 & 124,086 & 129,163 & 100,776 & 48,548 & 49,741 \\
\hline Michigan........ & 13,673 & 10,753 & 5,370 & 3,953 & 2,321 & $\mathbf{1}, 64 \mathrm{\Upsilon}$ & I,O I I \\
\hline Pennsylvania ... & 12,676 & II, 124 & 5,457 & 8,966 & 2,792 & 2,508 & 2,505 \\
\hline Ohio ........... & 12,473 & 19,323 & 22,254 & $32,53 \mathrm{I}$ & 24,153 & 21,618 & 20,819 \\
\hline Illinois ......... & $4,88 \mathrm{I}$ & 9,378 & 10,348 & 21,253 & 5,734 & 1,848 & 1,278 \\
\hline Gregon ......... & 4,388 & $\mathrm{I}, 662$ & 496 & 299 & 119 & 105 & 36 \\
\hline California ...... & 4,345 & 6,926 & 4,962 & 3,720 & 3,395 & 1,343 & I 50 \\
\hline
\end{tabular}

(From the Statistical Abstract of the United States).

Table no. 9 shows that New York was the largest cheeseproducing state from 1850 to 1900 . The production in 
New York increased rapidly from I850 to I880, but after this to I900 only slowly. Between 1900 and I9Io the production in New York fell off 25 million pounds while in Wisconsin it increased 70 million pounds. In 1909 Wisconsin produced I 49 million pounds, which is the largest amount produced by any state. In Pennsylvania the production of cheese increased slightly during the last decade, while in all other eastern states it decreased. It decreased in Illinois and California, where the demand for fresh milk is probably the cause for the decline. In Oregon, where the urban population is less numerous and the demand for fresh milk not so strong, the production of cheese increased by 3 million pounds during the last decade.

Like the butter industry, the cheese industry shows a tendency to migrate to sections of the country where the production of milk for fresh consumption is less profitable than in regions in close proximity to urban centers. Other factors that determine the distribution of these industries are soil, topography, climate, transportation charges, and social influences. The demand for fresh milk emanating from urban centers is the chief fundamental cause that brings about specialization in the production of butter, cheese, or milk for fresh consumption. When this force is felt in the dairy region, milk will be produced and the production of butter and cheese will be shifted to more remote parts of the country. Further differentiation between the production of butter and cheese seems to be due primarily to the adaptability of the soil to raise sufficient quantities of corn necessary in the feeding of hogs. When the yield of corn is reasonably large the hog may be made an adjunct of the butter industry by the utilization of skim milk. Where the yield of corn is very low hogs must be eliminated, and it then becomes more profitable to make cheese than butter. This is the chief cause ascribed to the 
distribution of butter and cheese factories in Dane County, Wisconsin, by B. H. Hibbard. ${ }^{1}$

The states that show the most pronounced dairy type of farming, whatever the product, according to the number of milch cows maintained on every square mile of land surface, are New York first with a little more than 30,500 milch cows to the square mile, Vermont second with nearly 30,000 , and Wisconsin third with a little more than $28,000 .^{2}$

\section{SOIL AND TOPOGRAPHY}

In connection with soil as a cause of the distribution of the dairy type of farming, two main ideas are found in popular dairy literature. It is stated that the soil in some sections of the country is peculiarly suited to dairying because of the adaptability to raise grasses. It is also contended that as the wheat belt moved westward and left in its wake a wide tract of partially worn-out land, diversified farming in which the dairy cow became a prominent feature was necessary to restore the fertility of the soil. The first statement holds that the cow needed the soil and the second that the soil needed the cow. Historically it may be said to be true that adaptability of the soil to grow certain grasses and the fertilization of the land through the cow, were at least secondary causes in the geographic distribution of dairying districts.

Before the 7o's the idea generally prevailed that in view of the fact that certain sections of the country were especially favored with sweet grasses, the dairy industry would attain its highest success in these districts. It was known of course that certain weeds produced an objectionable taste

'The History of Agriculure in Dane County, Wisconsin, p. I78.

${ }^{2}$ Calculations based on estimates of the distribution of milch cows in I9I4 made by the U. S. Department of Agriculture. Vide, Yearbook. 
in the butter. The western butter for a long time was said to have a "wild flavor" owing to the poor grass the cows were allowed to eat. ${ }^{1}$ On the other hand, the soil and topography of Orange County, New York, were believed to possess peculiarly favorable characteristics for the production of dairy products. Vermont also believed for some time that its possibilities could not be equaled by western sections. In 1870 the Secretary of the Vermont Dairy Association said that "our neighbors of the north-west ... have by the most persistent effort, by the most extended experiments, and the most vigorous researches, overcome obstacles, which we have, perhaps fondly, believed insurmountable". ${ }^{2}$

The dominating force that caused farmers to begin dairying in sections where this type of farming became specialized was not a special adaptability of the soil but the demand for the dairy products as compared with the demand for other products that it could produce. The dominating force was therefore an economic factor. The nature of the soil and topography were secondary and indirect causes of the distribution of dairying. After transportation was developed and the great plains of the West were opened for the production of beef and wheat, the eastern states could of course no longer afford to raise cattle, sheep, and grain to the exclusion of the production of dairy products. The former products could be raised at much lower cost on the cheap and level stretches of western land, while in the eastern sections the dairy products were in growing demand owing to an increasing urban population, and in consequence brought greater profits to the farmer than the pro-

${ }^{1}$ Article in N. Y. Tribune, copied by Ohio Agricultural Report for 1858, p. 299.

${ }^{2}$ Essay by O. S. Bliss, in Report of the Vermont Dairy Association for 1870 . 
duction of other products. The area at the present time supplying the city of Chicago with milk for fresh consumption, it is noticed, does not extend southward very far into the level stretches of Illinois, but rather northward into Wisconsin. ${ }^{1}$ South of Chicago there are vast level stretches of very fertile land which is principally devoted to raising corn, and which brings a larger income than if it were devoted to dairying. The section of the country northward into Wisconsin is less suited to raising corn. The yield of corn on this land is lower ${ }^{2}$ and the labor to produce corn, because of its uneven topography, considerably higher than in central Illinois. The influence of the soil upon the geographic distribution of the dairy industry is a negative one and not a positive one. When sections of the country remote from cities are rich in fertility and are level, making possible their cultivation at low cost, they will be devoted to the raising of grains, tobacco, etc. Specialized dairying is here excluded. These tracts could, as far as the adaptability of the soil is concerned, sow the land to artificial grasses and probably produce more butter than the more rolling sections. In view of the fact, however, that on these plains a rotation system of grain farming is more practical than specialized dairying, the farmer is bound to continue so long as the relative demand for agricultural products is not changed by a shifting of the urban centers of population and by the raising of grain in newer countries where the amount of capital invested in the land would be much less.

It is probably true that the cow was consciously used in numerous instances to fertilize the land impoverished by

Bulletin 138, Bureau of Animal Industry, U. S. Department of Agriculture.

${ }^{2}$ The average yield for Wisconsin as a whole is lower by over a bushel per acre than that of Illinois. Vide, Agricultural Yearbook. 
the "one-crop system"; but here again it was principally the economic force determining relative values of products that caused farmers to turn to the cow. In a reminiscent account $^{1}$ of conditions in western Pennsylvania, going back to I 849 , this statement is made: "Gradually it became apparent that the great West was about to supersede the eastern sections in supplying seaboard cities with beef, and as gradually the people turned their attention to other branches of husbandry. Some tried sheep and for a time prospered, but fluctuating prices and the many ills that the sheep is heir to proved disheartening, and the poor sheep are compelled to 'vamoose the ranche', and make room for the cow." This is a correct statement of the situation. Under existing economic conditions dairying was the most profitable and the safest type of farming that offered itself to many sections less adapted to the raising of staple crops.

It is a fact, historically, that the fertility of land has been largely maintained through the application of manure. That this is the quickest and most profitable way, however, has been disproved. The fertility of the soil can be maintained much more readily and at a lower cost by plowing under clover and other nitrogenous crops. C. G. Hopkins says, " a 50-bushel crop of corn removes from the soil 74 pounds of nitrogen, and eight tons of average manure or two tons of clover plowed under will return 80 pounds of nitrogen to the soil". 2 The contention is that by leaving on the land the straw of grain crops and all the grass cuttings except the last one which is used for seed, the productivity can be restored and maintained at a greater profit

${ }^{1}$ Second Annual Report of Transactions of the Pennsylvania State Dairyman's Association for 1876, pp. 311-4.

'Soil Fertility and Permanent Agriculture, p. 230. 
than through the use of manure. G. F. Warren ${ }^{1}$ points out that "on most farms selling butter, much less than half the fertility of the feed ever reaches the fields. It rots and wastes away around the barns, and is lost where cows stand in the pasture creek or where they congregate in the corner or under trees. Arguments against selling milk assume that when the skim milk is fed to hogs, the fertility is all saved. It would be interesting to know just how many acres in America have been manured with hog manure". Most of this carelessness as to the use of manure is due to a lack of information on the part of the average farmer. If scientific knowledge were thoroughly popularized, the manure including the liquid manure would all be saved and returned to the land providing the greatest return to labor could be secured in this way. If the peoples of the world allow themselves to be reduced to such a low standard of living as that obtaining in China we shall probably also utilize. like the Chinese farmer, every bit of manure, all human waste and canal dirt available." In Chinese agriculture the dairy cow is eliminated and all land devoted to products of greater food value. Hopkins ${ }^{3}$ says that " I, ooo bushels of grain have at least five times as much food value and will support five times as many people as will the meat or milk that can be made from it ". In view of this fact he contends that "livestock farming must and should continue to decrease, except on rough lands not suited to cultivation, in semi-arid sections where the average produce is not worth harvesting otherwise or in especially favored sections near the cities where dairy farming is profitable and may easily be made permanent because of the addition of manure

${ }^{1}$ Farm Management, p. 202.

2 Vide chapters 5 and 9 of F. H. King's Farmers of Forty Centuries.

${ }^{3}$ Hopkins, op. cit., pp. 234-5. 
hauled from town or made from purchased feeds". If population will grow much faster than means of subsistence the result will be as outlined. If the progressive methods of dairy organization, however, succeed in breeding up the dairy cow so as to produce annually an average of 300 or more pounds of butter, the cow is likely to be retained on most farms and the fertility of the soil will be maintained largely through a very careful application of the manure.

Scientific methods of restoring the fertility of the soil are not popularly known. The result has been therefore that farmers generally have used the manure of cattle in a more or less careless way. To say, however, that the need for manure was a primary cause in the geographic distribution of dairy regions is erroneous. If this were true the farmer would engage in stock raising and produce beef instead of dairy products. It is the relative values of farm products determined by demand that causes the geographic distribution of the dairy type of farming.

The topography of sections of the country has both negative and positive influences in causing the distribution of the dairy type of farming. Its influence is negative in regions where the land is extremely fertile and level. In such regions, dairying is usually crowded out by other types of farming. In rolling country its influence is positive because the numerous springs, ponds, and streams which abound in such regions offer a decided advantage for the cow and the care of her products over regions where these natural facilities are lacking. A prophecy bearing on this point was made by the New York Tribune in 1858 in the following language: "Lack of drainage which renders the construction of good cellars difficult, if not impossible, and lack of spring water, are serious obstructions to butter making in the West. The more northern and hilly 
states of Michigan, Wisconsin, and Minnesota, may be expected ultimately to obtain success in this important branch of husbandry". ${ }^{1}$ The first part of this statement is too emphatic in view of our progress in the dairy industry. The separator has made the care of the raw material for the manufacture of butter less difficult than it was formerly. Methods of control such as the general use of artesian wells, and mechanical refrigeration, have also since been developed and tend to supplement natural facilities.

\section{CLIMATIC INFLUENCES}

There are three important aspects of the effect of climate upon the dairy industry. The first is the effect upon cattle: the second, the effect upon shedding and feed; and the third the effect of the keeping qualities of the dairy products, making necessary the use of mechanical refrigeration in warm sections of the country.

The greatest disadvantage that a warm climate offers to cattle is found in the fact that warm weather breeds numerous pestering insects. Gnats, common flies, sand flies, ticks, and other insects are liable to annoy the milch cow a great deal more in warm than in cold climates. The most malicious of these insects is the cattle tick. Until recently all of the southern states from Virginia to Texas and including southern California had been infected with cattle ticks. These ticks frequently infest cattle in the south in such great numbers "as to stunt their growth and seriously affect their condition ". 2 They also spread the disease known as Texas fever among cattle. The U. S. Department of Agriculture in coöperation with the state governments has been making efforts to eradicate this enemy of

1 Reprinted in the Ohio Agricultural Report for 1858, p. 299.

'Vide, Circular 187, Bureau of Animal Industry, U. S. Department of Agriculture. 
dairying and stock raising since 1906. In the Yearbook of $1913^{1}$ considerable progress is reported, and it is predicted that if sufficient money be appropriated to carry on the work, the complete eradication will be effected before many more years have passed. Educating the farmer, quarantining infected areas, and the regular dipping of cattle in arsenical solution, are the steps necessary to bring about the eradication of the cattle tick. The cattle tick can be controlled, but, unless there is drastic governmental action taken, the probabilities are that it will always be more or less a pest in warm sections owing to the fact that there are irresponsible owners of cattle to be found scattered throughout all communities. The fact that these troublesome and pestiferous insects are much fewer in cold climates gives the northern states a decided advantage in this respect.

In shedding and feed, warm climates have a decided advantage over cold climates. On the Pacific Coast, for instance, where the climate is mild and equable, milch cows are stabled only from two to four months in the year. ${ }^{2}$ The same can be said of all southern states. The costs of capital are therefore considerably less in warm than in cold dairy regions. Feed is also much cheaper in warm climates. In the southern states " an unexcelled pasture can be maintained for at least eight months in the year. With the highly improved southern farms, the question of cheap feed is settled, for there is probably no section of America that can produce cheaper feed. Especially is the great variety of legumes that thrive in the South worthy of notice, and these crops, with cotton-seed meal, settle the question of protein ". 3

1 Page 62.

: Agricultural Yearbook for 1906, p. 422.

${ }^{3}$ Ibid., p. 42 I. 
High temperatures have a deteriorating effect upon milk and cream, and this fact gives to regions with comparatively cold climates a distinct advantage. Through the power separator it has become possible for a group of farmers to engage in butter making even in warm countries. The climatic conditions, however, require that the milk be hauled to the creamery every day, or after each mililing during the hottest part of the year, unless the milk is iced while on the farm. The hand separator also adds to the possibilities of butter making in warm sections. Obviously, taking care of the cream on the farm and transporting it to the creamery is less difficult than keeping all the milk in good condition.

Experiments have been conducted ${ }^{1}$ to show the comparative costs of mechanical refrigeration and the use of natural ice. Creameries in Illinois were chosen for the purpose. With the use of various kinds of insulation the experiments show the difference in cost to cool roo pounds of packed butter to 30 degrees Fahr., including cooling the cream during the manufacturing process between the natural ice system and the artificial refrigerating system, to be as follows:

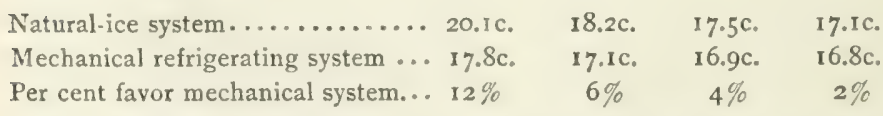

In these experiments the attempt was made to take account of all capital, labor and maintenance costs in both systems. It is shown that mechanical refrigeration is considerably cheaper in the latitude of Illinois than refrigeration through the use of natural ice. The writer who conducted these experiments believes, however, that the use of

1 Oscar Erf, in Bailey's Cyclopedia of American Agriculture, vol. iii, p. 245. 
natural ice becomes cheaper farther north because housing ice is less expensive.

So far, then, as the necessary refrigeration in the creamery or at outlying skimming and receiving stations is concerned, the warm dairy section is not under a very much greater disadvantage than is the cold region. To be sure refrigeration in warm regions has to be applied for a longer time throughout the year than in cold regions, but at the time both regions use refrigeration the cost is about the same. The great disadvantage, however, is felt on the farm, and while the milk or cream is being transported to the creamery. To keep the cream or milk on the farm in the southern states as long as it is kept in Wisconsin and Minnesota it would be necessary to use ice on each farm. This would be an expensive practice. Mechanical refrigeration is the cheapest method in most latitudes of the United States for use in the creamery, but the installation of a refrigerating plant on each farm would raise the cost of keeping dairy products on the average-sized farm much higher than the usual cost of this part of dairying in northern latitudes. It is of course possible to effect an organization whereby each farmer can be supplied with ice from a central manufacturing plant every day and his milk or cream taken to a central point for churning. This, however, compared with regions where it is not necessary, means increased cost.

\section{INFLUENCE OF CITIES}

In regions where the soil, topography, and climate are favorable to dairying, the force that causes specialization in the production of fresh milk or butter and cheese, is the influence of the city. In other words, the causes that differentiate the city-milk-producing area, are the demand for fresh milk, the demand for hay and forage to feed draught 
animals, and the demand for vegetables and potatoes. Milk is a very perishable product and must be produced near the place where it is consumed. Hay, forage, vegetables and potatoes are bulky products and the transportation charge on them is comparatively high. The tendency therefore is to satisfy the strong demand of the city for these products from near-by regions. Less bulky and less perishable products are crowded out and are raised in more remote parts of the country. It follows, therefore, that butter, being a highly concentrated food and having a low transportation charge, is principally produced in regions adapted to dairying but lying outside of those dairy districts that can more profitably be devoted to the production of milk for fresh consumption and to the production of hay, forage, vegetables, and potatoes.

The area ${ }^{1}$ supplying the city of Boston and a number of smaller cities and towns in its vicinity with milk and cream in 1905 comprised the southwestern part of Maine, the lower half of New Hampshire, the center of Vermont along the Boston and Maine railroad, two-thirds of Massachusetts, and the northeastern part of Connecticut. This area is covered with a network of railroads. The greatest distance at which milk was brought into Boston during the year of 1905 was 86 miles from Connecticut, 2 I 3 miles from Vermont, 20I miles from New Hampshire, and 129 miles from Maine.

The field supplying New York City with milk and cream in 1905 comprised the northern part of New Jersey, the eastern part of Pennsylvania, and a large part of eastern, central, and northern New York, as may be seen by consulting table no. Io. ${ }^{2}$

${ }^{1}$ Vide, Bulletin 8I, Bureau of Animal Industry, U. S. Department of Agriculture.

${ }^{2}$ From Bulletin 8I, Bureau of Animal Industry, Department of Agriculture. 
TABLE $\mathrm{X}$

Time Milk Trains leave, Distance Traveled, and Time on Road

\begin{tabular}{|c|c|c|c|c|c|}
\hline Railroad & Starting Point & Distance & $\begin{array}{l}\text { Time } \\
\text { leaves }\end{array}$ & $\begin{array}{l}\text { Time } \\
\text { arrives }\end{array}$ & $\begin{array}{l}\text { Time } \\
\text { on road }\end{array}$ \\
\hline N. Y., O. \& W... & $\begin{array}{l}\text { Sidney, N. Y......... } \\
\text { Central Square, N. Y.. }\end{array}$ & $\begin{array}{c}\text { Miles } \\
201 \\
300\end{array}$ & $\begin{array}{l}\text { a. } \mathrm{m} . \\
10.35 \\
7.25\end{array}$ & $\begin{array}{l}\text { p. m. } \\
10.10 \\
10.50\end{array}$ & $\begin{array}{ll}\text { h. } & \mathrm{m} . \\
\text { II } & 35 \\
\text { I5 } & 25\end{array}$ \\
\hline D., L. \& W. & $\begin{array}{l}\text { Elimira, N. Y........ } \\
\text { Syracuse, N. Y. . . . } \\
\text { Utica, N. Y.... . . } \\
\text { Ricbfield Springs ..... }\end{array}$ & $\begin{array}{l}264 \\
287 \\
302 \\
311\end{array}$ & $\begin{array}{l}8.40 \\
9.05 \\
9.30 \\
9.10\end{array}$ & $\begin{array}{r}9.33 \\
10.22 \\
10.36 \\
10.36\end{array}$ & $\begin{array}{ll}12 & 53 \\
13 & 17 \\
13 & 06 \\
13 & 26\end{array}$ \\
\hline N. Y., N. H. \& H. & $\begin{array}{l}\text { Pittsfield, Mass....... } \\
\text { Hornellsville, N. Y.... }\end{array}$ & $\begin{array}{l}155 \\
332\end{array}$ & $\begin{array}{l}\text { p. m. } \\
\text { I } 2.10 \\
\text { a. } \mathrm{m} \text {. } \\
8.07 \\
\text { p. } \mathrm{m} .\end{array}$ & $\begin{array}{l}10.12 \\
10.15\end{array}$ & $\begin{array}{l}1002 \\
1408\end{array}$ \\
\hline Erie. & 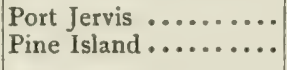 & $\begin{array}{l}89 \\
72\end{array}$ & $\begin{array}{r}4.50 \\
4.25\end{array}$ & $\cdots \cdots \cdots$ & $\begin{array}{ll}\cdots \\
\cdots & \cdots\end{array}$ \\
\hline Lehigh Valley .... & Clockville..... & 387 & $\begin{array}{l}\text { a. } \mathrm{m} \text {. } \\
8.04\end{array}$ & 10.30 & 1426 \\
\hline N. Y. Central ..... & $\begin{array}{l}\text { Massena Springs ...... } \\
\text { Ogdensburg ......... }\end{array}$ & $\begin{array}{l}396 \\
372\end{array}$ & $\begin{array}{r}7.00 \\
11.00\end{array}$ & \begin{tabular}{|l|}
11.00 \\
$\cdots \ldots$
\end{tabular} & $16 \ldots$ \\
\hline N. Y., Sus. \& W... & $\begin{array}{l}\text { Middletown, N. Y.... } \\
\text { Stroudsburg, Pa..... }\end{array}$ & $\begin{array}{r}90 \\
102\end{array}$ & $\begin{array}{r}\text { p. m. } \\
3.10 \\
2.46\end{array}$ & $\begin{array}{l}10.30 \\
10.30\end{array}$ & $\begin{array}{ll}720 \\
744\end{array}$ \\
\hline
\end{tabular}

The longest haul for milk for New York City in 1905 was 396 miles, which was from Massena Springs, a point in northern New York not far from the St. Lawrence River. The time that the milk is in transit from this point is 16 hours.

"Most of the milk supply of Chicago is produced within 60 miles of the city, and a roo-mile circle about the city would include nearly all of the dairies producing its supply, though in times of exceptional scarcity in the summer, sweet cream is shipped 200 miles." 1 The Chicago citymilk area is therefore much smaller than the New York

${ }^{1}$ Vide, Bulletin 138 , Bureau of Animal Industry, Department of Agriculture. 
and Boston areas. This is due to the fact that around Chicago there are not the many suburban towns, scattered villages and small cities that dot the country throughout the eastern states.

Within the city-milk area there is of course also butter produced. Some of the butter produced, however, is made from surplus milk. The two industries of furnishing fresh milk and cream and producing butter seem to be coupled by most of the milk dealers. This is necessary not only for the purpose of working up the surplus milk that is not absorbed by the urban population at current prices, but also to enable the dealer to draw upon any amount of milk that variations in demand may require. The plan therefore brings flexibility into the supply of milk and obviates all losses resulting from sour milk or the inability to utilize by-products.

The conditions that make it imperative that milk for fresh consumption be produced in near-by regions, are the increasing transportation charge as the distance increases and the effect that time has upon the quality of the milk.

The transportation charges ${ }^{1}$ of 40 -quart milk cans shipped into New York City are as follows:

Cents per can.

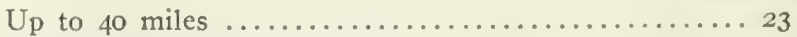

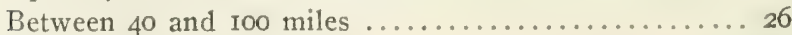

Between 100 and 200 miles .................... 29

200 miles and over ....................... 32

There is a difference of nine cents a can between the highest and the lowest rates of bottled milk and cream. The difference between the highest and lowest rates for

i These rates were in effect in 1905 and were based on a zone system upon the recommendation of the Interstate Commerce Commission. Vide, Bulletin 8I, Bureau of Animal Industry, U. S. Department of Agriculture. 
milk bottled in the country and shipped into New York is 68 cents for a 12 -bottle case. On cream the difference is 32 cents.

The rates in effect in I9I I on three railroads hauling milk into Chicago were as follows on 32 -quart cans: ${ }^{1}$

(I) Less than 25 miles, I2 cents; 25 to 50 miles, I5 cents; 50 to 75 miles, 20 cents.

(2) Less than 36 miles, I 5 cents; 36 to 42 miles on main line and to 49 miles on branches, I 6 cents; 42 to 46 miles on main line, I 7 cents; 52 to 59 miles, I 8 cents; 62 to 66 miles, I9 cents; 68 to 83 miles, 20 cents.

(3) Less than Io miles, $14 \frac{1}{2}$ cents; Io to $2 \mathrm{I}$ miles, I5 cents; $2 \mathrm{I}$ to 30 miles, $15 \frac{1}{2}$ cents; 32 to 55 miles, 16 cents ; 55 to 62 miles, $I 7 / 2$ cents.

TABLE XI

Relative Value of Crops in Different Geographic Divisions of THE Uniten States

\begin{tabular}{|c|c|c|c|c|c|c|}
\hline \multirow[b]{2}{*}{ Division } & \multicolumn{2}{|l|}{$\begin{array}{l}\text { Crop ranking } \\
\text { first in value }\end{array}$} & \multicolumn{2}{|c|}{$\begin{array}{l}\text { Crop ranking } \\
\text { second in value }\end{array}$} & \multicolumn{2}{|c|}{$\begin{array}{l}\text { Crop ranking } \\
\text { third in value }\end{array}$} \\
\hline & Kind & 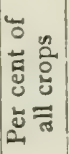 & Kind & 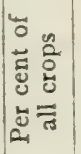 & Kind & 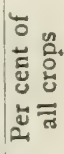 \\
\hline $\begin{array}{l}\text { New England... } \\
\text { Middle Atlantic.. } \\
\text { E. N. Central ... } \\
\text { W. N. Central... } \\
\text { South Atlantic... } \\
\text { E. S. Central.... } \\
\text { W. S. Central ... } \\
\text { Mountain ...... } \\
\text { Pacific........ }\end{array}$ & $\begin{array}{l}\text { Hay \& Forage } \\
\text { Hay \& Forage } \\
\text { Corn ............ } \\
\text { Corn .......... } \\
\text { Cotton ........ } \\
\text { Cotton ........ } \\
\text { Cotton ...... } \\
\text { Hay \& Forage. } \\
\text { Hay \& Forage. }\end{array}$ & $\begin{array}{l}41.9 \\
31.4 \\
38.9 \\
34.8 \\
40.8 \\
37.1 \\
49.9 \\
40.5 \\
26.5\end{array}$ & 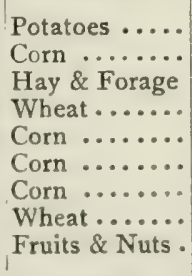 & $\begin{array}{l}12.4 \\
10.9 \\
16.5 \\
25.2 \\
20.1 \\
27.4 \\
22.8 \\
15.8 \\
21.4\end{array}$ & $\mid \begin{array}{l}\text { Vegetables ... } \\
\text { Vegetables ... } \\
\text { Oats ....... } \\
\text { Hay \& Forage } \\
\text { Vegetables ... } \\
\text { Tobacco ..... } \\
\text { Hay \& Forage } \\
\text { Oats ........ } \\
\text { Wheat ....... }\end{array}$ & $\begin{array}{r}9.1 \\
8.1 \\
13.3 \\
14.6 \\
5.7 \\
8.3 \\
4.7 \\
12.0 \\
18.6\end{array}$ \\
\hline
\end{tabular}

(From U. S. Census, 1910, vol.v, p. 541)

2 Vide, Bulletin 138, Bureau of Animal Industry, U. S. Department of Agriculture. 
As the length of the haul increases fresh milk becomes more and more expensive, and the effect is to intensify fresh-milk production within a limited area and to force butter production outside of this area.

The fact also that much of the milk produced in the morning cannot be made available for consumption before the following morning when hauled long distances, is another inhibition against spreading the production of city milk over an extended area.

In the sections of the country as listed in table no. II, dairying is most important in the first four geographic divisions. In the New England and Middle Atlantic states the

TABL.E XII

Value of Hay and Forage per Ton ANd Average Yield per ACre

\begin{tabular}{|c|c|c|c|c|c|c|}
\hline \multirow{3}{*}{ United States } & \multicolumn{2}{|c|}{ Average value per ton } & \multicolumn{4}{|c|}{ Average yield per acre (tons) } \\
\hline & 1909 & 1899 & 1909 & I 899 & 1889 & 1879 \\
\hline & $\$ 8.46$ & $\$ 5.76$ & $\mathbf{1} \cdot 35$ & I. 28 & I. 26 & I.15 \\
\hline New England ......... & 12.69 & 9.48 & 1.23 & I.13 & r.o9 & 0.96 \\
\hline Middle Atlantic....... & 11.56 & 8.97 & 1.32 & I.19 & 1.29 & I.10 \\
\hline E. N. Central .......... & 9.06 & 6.26 & 1.38 & 1.22 & I. 30 & 1.17 \\
\hline W. N. Central ......... & 5.82 & 3.48 & 1.33 & 1.34 & I. 26 & 1.32 \\
\hline South Atlantic......... & 12.97 & 9.06 & 1.02 & 1.02 & 1.09 & 0.84 \\
\hline E. S. Central............ & 11.55 & 8.39 & 1.03 & 1.03 & 1.06 & 0.82 \\
\hline IV. S. Central........... & 8.80 & 3.98 & 1.03 & 1.48 & I. 35 & 0.83 \\
\hline Mountain ............ & 7.73 & 5.15 & 1.73 & 1.59 & I. 36 & 1.13 \\
\hline Pacific.............. & 10.20 & 6.31 & 1.73 & 1.44 & I.49 & I.45 \\
\hline
\end{tabular}

(From U. S. Census.)

crops ranking first in value are hay and forage. This is due to the fact that the demand caused by the existence of the great number of draught animals in cities and smaller urban centers makes it profitable to raise hay and forage. As shown in table no. I2, the average value per ton of hay is 
higher in New England and the Middle Atlantic states than in the East and West North Central states. This is of course due to the fact that hay and forage are in great demand in the east, and, having a high transportation charge, they can be raised more profitably in the east than in the middle west.

The census figures show that there is a slight change in progress as to the number of draught animals used in the big cities.

\section{TABLE XIII}

The Number of Draught Animals (Horses, Mules, Asses, and Burros) in LaRge Cities of the United States in IgOo AND 1910

\begin{tabular}{|c|c|c|}
\hline City & 1910 & 1900 \\
\hline 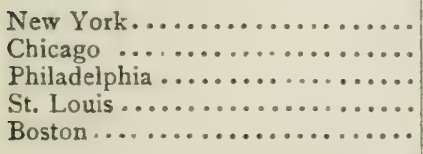 & $\begin{array}{r}129,370 \\
69,320 \\
51,804 \\
31,362 \\
23,033\end{array}$ & $\begin{array}{r}130,695 \\
74,362 \\
51,041 \\
32,623 \\
25,760\end{array}$ \\
\hline
\end{tabular}

(From U. S. Census.)

In the largest cities of the United States, as table no. I 3 shows, the number of draught animals is slightly decreasing due to the increasing use of the automobile truck. In all smaller cities, however, the number has increased during the last decade. To the extent that the automobile displaces the horse and mule, the demand for hay and forage from the city will be lessened. If this substitution goes on to any appreciable extent. much of the acreage in the eastern states now devoted to the growing of hay and forage can be released and made available either for the production of city-milk or bulky crops for which there is a strong demand. 
TABLE XIV-ACREAGE OF HAY,

\begin{tabular}{|c|c|c|c|c|}
\hline \multirow{2}{*}{$\begin{array}{l}\text { Geographic } \\
\text { Division }\end{array}$} & \multicolumn{4}{|c|}{ Hay \& Forage, Acreage } \\
\hline & Ig09 & 1899 & 1889 & 1879 \\
\hline $\begin{array}{l}\text { New England........ } \\
\text { Middle Atlantic..... }\end{array}$ & $\begin{array}{l}3,797,598 \\
8,532,793\end{array}$ & $\begin{array}{l}4,050,025 \\
8,869,016\end{array}$ & $\begin{array}{l}4,180,355 \\
9,024,966\end{array}$ & $\begin{array}{l}4,254,246 \\
7,772,118\end{array}$ \\
\hline
\end{tabular}

Fer cent of increase from 1899 to 1909

New England.........

Middle Atlantic......

\section{-6.2
-3.8}

(From U. S. Census.)

That the acreage devoted to hay and forage in the eastern states is decreasing is shown by table no. I4. This is partially due to the fact that the yield per acre has steadily increased from 1879 to I909. Table no. I 2 shows that the increase in the average yield per acre during this time was .27 tons for New England and .22 tons for the Middle Atlantic states. The larger portion of the decrease in the acreage devoted to hay and forage, however, has been forced by an increase in the acreage of potatoes and vegetables. As table no. I4 shows, the percentage increase in the acreage devoted to potatoes from I 899 to I 909 was 29.5 in New England and 7.8 in the Middle Atlantic states. The percentage increase of the acreage devoted to vegetables during the same period was 27.I in New England and $18 . \mathrm{I}$ in the Middle Atlantic states.

In the light of these facts it is plain that butter production can not become intensified in dairy regions close to urban centers. The industry as a specialty must move to sections of the country where the soil, topography, and climate are naturally favorable, and where the influences 
Forage, Potatoes, and Vegetables

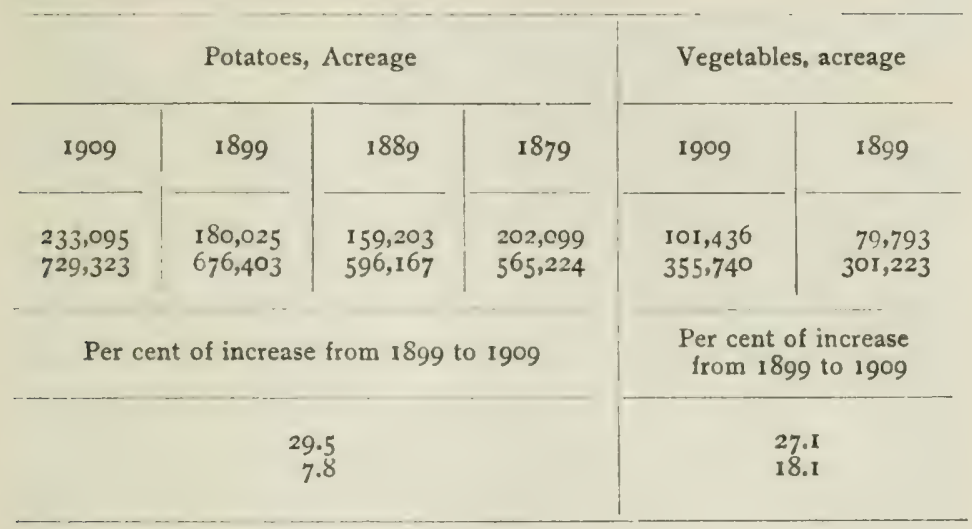

growing out of the centers of population are less strongly felt.

\section{SOCIAL INFLUENCES}

There are three aspects of society that influence the distribution of butter-producing areas-special training and skill in the manufacture of dairy products on the part of a large number of people, the people's attitude toward labor, and their attitude toward progress.

There are communities in Europe, notably in Switzerland, the Netherlands, Germany, Scandinavia, and in parts of England and Scotland, where the people have made butter and cheese for many centuries. The rural people of Switzerland, Scandinavia, and Germany are therefore well trained in the art of making butter and cheese. When these classes of people come to America they are very likely to engage in the line of pursuits with which they are most familiar. The expert information they have concerning dairy products is also likely to be communicated to their neighbors and through them result in a further develop- 
ment of the dairy industry. A great many Germans are scattered throughout Iowa, Michigan, Wisconsin, and Minnesota, and in Wisconsin and Minnesota there are a great many Norwegians and Swedes. With most of these people the art of making butter and cheese is a heritage that has been handed down to them by their ancestors.

The attitude of the rural population toward labor has much to do with making successful dairying possible. The classes of people above referred to are all industrious, intelligent, and thrifty. The women as well as the men do a day's work cheerfully and with dignity. Their intelligence enables them to appreciate the value of sanitary methods in handling dairy products. In sections of the country where the more intelligent agricultural population is indisposed toward manual labor and where the work has to be done, if it is done at all, by a class that is for the most part irresponsible, dairying can never be very successful.

The wonderful strides that some of the states in the north central group have made in recent years in the dairy industry is not alone due to natural and economic causes, but is without a doubt due in considerable part to the progressiveness of the people. The same could be said concerning some of the eastern dairy states. One need only read resolutions offered at dairy conventions to see how earnestly and enthusiastically these people attack all problems that confront them. Following is part of a resolution adopted by the Wisconsin Dairymen's Association in $1882:{ }^{1}$

Resolved, That we recognize gratefully that the general public regard this Association and the dairy interest as among ... the leading interests of the times; and we hereby pledge to each other that in returning to our homes we will profit by the thoughts and suggestions received here.

${ }^{1}$ Vide, Report, p. 92. 
Another resolution adopted by the Michigan Dairy Association in IgOr $^{1}$ is in part as follows:

Resolved, That the State Dairy Association hereby extends its congratulations to the state of Michigan, and particularly to the State Board of Agriculture on the completion of the long desired building for dairy instruction at the college. . . . This Association agitated the question of a dairy building for several successive annual meetings and we congratulate ourselves and the college that this agitation has finally resulted in the erection of a suitable building.

The aggressive efforts of dairy associations have done a great deal in arousing the lethargic members of the community, in securing favorable legislation, in educating the ignorant, in instilling in many the desire for a knowledge of agriculture and dairy science, in inspiring many to aspire to leadership in agricultural organizations, and in creating a medium of intelligence that makes rural life attractive and that tends to keep the young people on the farm. Vermont was the first state to organize a state dairy association. The Vermont Association was organized in 1869 and has had a very active history. It receives $\$ \mathrm{I}, 000$ state aid. Wisconsin organized its dairy association in 1872 , and since then has added four other associations interested in butter and cheese products. The first association receives $\$ 3,000$ state aid and two others receive $\$ 600$ each, making a total of $\$ 4,200$ state aid to dairy associations. The associations in Iowa, Illinois, and Minnesota also receive large sums from the state. A review ${ }^{2}$ of dairymen's associations shows that the states that have made the greatest progress in recent years all have active dairymen's associations, and as a rule receive large sums from the state to carry on their propaganda of education.

'Vide, Report, pp. I08-9.

2Vide, Circular 204, Bureau of Animal Industry, U. S. Department of Agriculture. 


\section{CHAPTER IV}

\section{Organization for Dairy Education}

Dairying is specialization in farming, and is never carried on to the complete exclusion of all other types of farming. In our system of education there is the same relation between dairying and the general field of agriculture as obtains in practice. The machinery that promotes dairying is a part of the organization that is devoted to the investigation of all agricultural subjects and to the dissemination of all agricultural knowledge. Our present organization for agricultural education owes its existence to the Morrill Act of 1862 which made provision for the establishment in each state and territory of a land-grant college to teach agriculture and the mechanic arts. In I 887 the Hatch Act provided for the organization of an experiment station as a department in each land-grant college. In these landgrant colleges four-year courses in dairying are given as well as short courses covering only the more practical phases. In addition to the land-grant colleges, numerous private colleges, academies, and high schools over the country are now teaching agriculture, including dairying.

Agricultural education of the higher order is of little value if it can not be scattered among the farmers that actually turn the sod; and in order that the scientific principles developed in the laboratory may be actually put into practice on every farm in the country there has been organized special machinery whereby agricultural science can be popularized. Among these are institutes, instructional trains, 
demonstrations, movable schools, correspondence courses, and reading courses. These are in mose cases connected with the extension work of the agricultural colleges. In addition to these organized efforts there are state dairy associations and state dairy and food commissioners also largely engaged in the dissemination of facts pertaining to the dairy industry.

The purposes and aims of these extensive efforts in agricultural education may be said to be twofold-the increase of agricultural productivity and the adjustment of the individual to the agricultural environment. As regards the subject of dairying the educational aims are first and foremost to increase productivity. This field also includes a study of the markets. Another important phase is sanitation. Dairy products must promote the public health. Much attention is also given in agricultural colleges to training the individual in the practical work of butter and cheese manufacture and the production and handling of milk for fresh consumption. The ends sought in this dairy education are social betterment in its widest meaning and the adjustment of the individual to the dairy industry.

\section{THE LAND-GRANT COLLEGES}

Through the efforts of Justin Smith Morrill, whose 32 years of service as Senator from Vermont won for him the title of "father of the United States Senate", a bill providing for the establishment of agricultural colleges after having been vetoed by the president, passed both houses of Congress for the second time and became a law with the president's approval, July 2, I 862.

Joint federal and state legislative action was necessary to carry out the ends and purposes of the bill. The federal government apportioned 30 thousand acres of public land for each senator and representative in Congress among the 
states. The money derived from the sale of such lands was to be invested in safe stocks bearing not less than 5 per cent interest. The principal was to remain intact forever, and only the interest was to be applied to the maintenance of the college. The states had to comply with these provisions by legislative act before they were entitled to their share of the land.

The leading object of the land-grant college, as set forth in the Morrill Act of I862, is, "without excluding other scientific and classical studies, and including military tactics, to teach such branches of learning as are related to agriculture and the mechanic arts in such manner as the legislatures of the states may respectively prescribe in order to promote the liberal and practical education of the industrial classes in the several pursuits and professions in life". In the second Morrill Act of 1890 , it was further specified that the instruction " shall include the English language, and the various branches of mathematical, physical, natural, and economic science with special reference to their applications in the industries of life and to the facilities for such instruction ". In 1908, it was also provided that the agricultural colleges may train teachers of agriculture. ${ }^{1}$

Coördination of these colleges into a national system of education was obtained by requiring them to issue annual reports concerning the result of their experiments, etc., and by requiring each college to send a copy of this report to all other colleges and to the Secretary of the Interior. The Act of I 890 strengthened this coördination by requiring a copy of the annual report to be sent also to the Secretary of Agriculture. Another feature that resulted in stronger coördination is the granting of federal money in the form of annual appropriations embodied in the Act of 1890.

${ }^{1} 34$ Stat. L., 1256, 1281. 
This establishes federal control over the methods of expending the money appropriated by Congress. The Act requires the Secretary of the Interior to ascertain whether or not each state and territory is complying with all the provisions of the federal statute, and to certify his findings to the Secretary of the Treasury, who shall pay or withhold the money appropriated according as these provisions have or have not been complied with.

The further endowment of the agricultural colleges provided for in the Act of 1890 consisted of an appropriation of $\$ r_{5}, 000$ to be paid to each state and territory for the fiscal year ending June 30 , I890, and an annual increase of the appropriation to each college by $\$ 1,000$ for ten years. After that each college was to get $\$ 25,000$. This sum was to be paid out of funds arising out of the sale of public lands.

In the appropriations made for the Department of Agriculture for the fiscal year, ending June 30, I908, the appropriation to each college was to increase annually $\$ 5,000$ until the total sum appropriated to each college would be $\$ 50,000$. This sum, according to the provisions of the Act, can be paid out of any money in the treasury. The federal aid given to the land-grant colleges consists, therefore, of the interest accruing from the original fund established through the apportionment of land among the states and of subsequent annual appropriations to each college. The appropriations now amount to $\$ 50,000$ a year. The colleges have also received liberal aid from the states and from private sources.

THE EXPERIMENT STATIONS

Under authority of the Hatch Act of I887, agricultural experiment stations were established as departments in the land-grant colleges. Section 2 of this act describes the object of the experiment station to be as follows: 
That it shall be the object and duty of said experiment stations to conduct original researches or verify experiments on the physiology of plants and animals; the diseases to which they are severally subject with the remedies of the same; the chemical composition of useful plants at their different stages of growth; the comparative advantages of rotative cropping as pursued under the varying series of crops; the capacity of new plants or trees for acclimation; the analysis of soils and water; the chemical composition of manures, natural or artificial, with experiments designed to test the comparative effects on crops of different kinds; the adaptation and value of grasses and forage plants; the composition and digestibility of the different kinds of food for domestic animals; the scientific and economic questions involved in the production of butter and cheese; and such other researches or experiments bearing directly on the agricultural industry of the United States as may in each case be deemed advisable, having due regard to the varying conditions and needs of the respective States and Territories.

The section specifically requires that original researches shall be conducted on the " scientific and economic questions involved in the production of butter and cheese". Dairy investigations in states where dairying is a prominent type of farming, are further urged by the general statement of the section that in the investigations of agricultural problems due regard must be had "to varying conditions and needs of the respective States and Territories".

Sec. 3 of this act welds these experiment stations into a national system. Each station is required to report to the Secretary of Agriculture on special forms prescribed by him concerning the results of investigations or experiments. The Secretary is also charged " to indicate from time to time such lines of inquiry as to him shall seem most important, and, in general, to furnish such advice and assistance as will best promote the purpose of this act". An- 
nual reports must also be sent to other colleges and to the Secretary of Agriculture.

The Hatch Act provided for an appropriation of fifteen thousand dollars to be paid to each state and territory maintaining an agricultural college for the purpose of establishing a department to be known as an experiment station. This sum was yearly paid to each station until I9o6, when the Adams Act provided an increase of five thousand dollars and thereafter an annual increase of two thousand dollars until the amount reached thirty thousand dollars.

CO-ORDINATION OF LAND-GRANT COLLEGES AND EXPERIMENT STATIONS

The Office of Experiment Stations has been organized in the U. S. Department of Agriculture upon authority contained in the Morrill Act of August 30, 1890, in the Hatch Act of 1887 , and in subsequent agricultural appropriation acts, to direct the lines of inquiry among the experiment stations and to receive reports from the president of each land-grant college. The Office publishes the Experiment Station Record which is a valuable account of the progress of the stations and contains information of agricultural progress in general. The relation between this office and the colleges and experiment stations is of a coöperative character, each college and experiment station acting more or less independently but in harmony with the U. S. Department of Agriculture.

The Office of the Experiment Stations provides a connecting link between all land-grant colleges and experiment stations. In addition to this coördination the land-grant colleges formed an organization October I8, i887, known as the Association of American Agricultural Colleges and Experiment Stations with which the Office of Experiment Stations of the U. S. Department of Agriculture and the 
Bureat of Education of the Department of the Interior are also affiliated.

The work of the Association has resulted in standardizing agricultural education throughout the United States. "At its convention of $\mathrm{I}_{994}$ it appointed a committee on entrance requirements, courses of study, and degrees, whose final report presented two years later was adopted. ${ }^{1}$ In I 895 , a permanent committee on methods of teaching agriculture was appointed. This committee has issued many reports, the thirteenth report being "a secondary course in animal husbandry and dairying". While these reports of the committee have been adopted by the association, their recommendations have not always been accepted by all of the colleges. The work as a whole, however, has served to bring unity into courses and educational standards.

\section{COURSES IN DAIRYING}

The agricultural colleges offer four-year courses in agriculture, and some offer also graduate courses leading to the degree of Ph. D. In these courses the work of the student in some institutions is prescribed for one and one-half or two years and the remainder is elective. The elective principle is often restricted by the idea of grouping allied subjects. That is, the student is allowed to specialize at his own discretion, but in deciding upon a major he must also take a certain number of related subjects. At Cornell University, for instance, the student's work is prescribed for the first two years and during the last two years he is allowed to choose between 2 I groups. These groups are as follows: “( ( ) Farm practice, (2) agricultural chemistry, (3) entomology and general invertebrate zoology, (4) plant physiology, (5) plant pathology, (6) soil technology,

${ }^{x}$ Circular T06, Office of Experiment Stations, U. S. Department of Agriculture. 
(7) farm crops and farm management, (8) plant breeding, (9) horticulture, (IO) animal husbandry, (II) poultry husbandry, (I2) dairy industry, (I3) farm mechanics, (14) rural economy and sociology, ( 15 ) rural art, (I6) drawing, (I7) pomology, (18) meteorology, (I9) extension teaching, (20) forestry, and (2I) rural education".

"Most of the state agricultural colleges and some other institutions offer courses in dairying, varying in length from only a few weeks to four years." 2 In the dairy school of the Iowa State College of Agriculture and Mechanic Arts, four-year, one-year, and two-week courses are offered. The plan of giving both the intensive four-year courses as well as the short practical courses in dairying is followed by practically all the colleges.

The four-year college course is intended for the leaders in dairying. Some of the college graduates prepare for teaching. Others drift into administrative work, into bureaus of chemistry where dairy products are analyzed, into dairy journalistic work, and into practical dairy specialization.

The four-year college dairy course is too theoretical to be taken by the ordinary farmer owning a dairy herd or by the operator of the cheese factory or the creamery. These men need more especially information concerning the practical phases of their work and less theory. In nearly all colleges, therefore, short courses are provided to meet this need. In the IVisconsin University "the winter dairy course lasts 12 weeks and requires for admission one season's previous training in a creamery or cheese factory. A summer dairy course is offered to a limited number of students, who will be admitted without previous factory train-

${ }^{1}$ Circular 106, Office of Experiment Stations, U. S. Department of Agriculture.

${ }^{2}$ Circular 204, Bureau of Animal Industry, U. S. Department of Agriculture. 
ing and may remain the whole season. To secure a dairy certificate the student must have had two seasons' actual practice in a factory, one of which must follow his work at the dairy school. A two-week's farmer's course, limited to persons who are at least 25 years of age; a housekeepers' conference; a week's special course for cheese-factory and creamery operators and managers; a summer dairy course (ro days) for beginners or those with little practical knowledge of creamery or dairy work, and summer courses in agriculture, agricultural education, and home economics are also offered." ${ }^{1}$

MACHINERY FOR THE POPULARIZATION OF SCIENCE

The greatest difficulty that agricultural education has to deal with is the general introduction of newly-discovered truths among the people. Many important principles have been discovered, that, if put into practice. would very materially increase the productivity of the land and result in improving the general welfare of all classes of our population. Among such principles may be mentioned the restoration and maintenance of the fertility of the soil and the increase of the yield of the dairy cow through elimination and breeding. In spite of the fact that agricultural colleges and other institutions have stood ready for years to scatter this linowledge broadcast. the majority of farmers move along in the rut that was followed by their fathers or grandfathers. The influence of the college does not reach every nook and corner of the state, and those people whom it does reach are frequently not actually engaged in tilling the soil. This fact was of course early recognized by the land-grant colleges, and efforts have been made to establish institutions that would bring the agricultural message to the farmer.

${ }^{1}$ Bulletin 253, Office of Experiment Stations, U. S. Department of Agriculture, p. 90. 
Among such institutions are the various forms of extension work which are in most cases superintended by the state agricultural college, but in some cases by the office of the state department of agriculture or by the state dairy and food commissioner. The short courses in dairying offered by the agricultural colleges, already referred to, play an important part in the popularization of dairy science.

The farmer's institute is one of the oldest organizations utilized to get into touch with the farmer. Nany states have a permanent organization in each county looking after the details of meetings. In Indiana, Kansas, Ohio, Oklahoma, South Dakota, and Wyoming, these local organizations receive state aid. ${ }^{1}$ It is urged, however, that county organizations are insufficient to reach everybody in the county and that permanent local organizations are necessary to interest the people. At the farmers' institutes all subjects of agriculture are discussed, including of course dairying. The meetings are well attended. Lectures given by college professors bring new ideas before the people, but it has been found that the influence of the institute is too often only inspirational and too infrequently results in the final application of the principles expounded. In view of this fact efforts are now made to follow up the work of the institute with the instructional train, the demonstration, and the movable school.

The instructional train is furnished by the railroad for the express purpose of interesting the farmers along the road in improved methods of agriculture. In IgIo the Rock Island railroad operated trains in Io states, covered over Io,800 miles and reached over I72,000 people. ${ }^{2}$ In I9I 3 , the distance traveled by 25 different trains of this

${ }^{1}$ Bulletin 25I, Office of Experiment Stations, U. S. Department of Agriculture, p. 8.

${ }^{2}$ Idem, p. 39. 
type was 24,725 miles. ${ }^{1} \quad$ The railroads are interested in increasing their freight revenue and find it profitable to advocate the raising of hogs, the establishment of creameries, the adoption of the best methods in growing corn, wheat, etc.

Demonstration work is usually carried on by the extension departments of the agricultural colleges. Places are selected and widely advertised. The most frequent demonstration pertaining to dairying that is made, is the testing of the farmer's milk for butter fat. The purpose of this of course is to show him whether or not his cows are profitable. Tuberculin tests are made and live-stock is judged. Demonstrations of a general character include spraying, pruning, packing, cooking of foods, killing of insects and animals, etc. "Thus saying crystallizes into doing, processes into results, and hazy impressions into clear convictions. Slowly, even imperceptibly, as the results of one or more successful demonstrations, the farmers of a community come to realize that science has a message for them, and that the teaching of agriculture can interpret that message and show its applications to the farmer." 2

Perhaps the most fruitful institution yet established to educate the practical farmer is the movable school. This school, like the demonstration work is conducted by the extension departments of the colleges of agriculture. The movable school is an innovation in popular agricultural education. In I9I3, movable schools were conducted in I3 different states, and altogether ${ }^{8} 87$ schools were held during the year. The average length of the school was five days. ${ }^{3}$ Farmers of all ages are invited to register. Atten-

${ }^{1}$ Bulletin 83, U. S. Department of Agriculture, p. 30.

${ }^{2}$ W. C. Latta in Bulletin 25I, Office of Experiment Stations, U. S. Department of Agriculture, p. 23.

${ }^{8}$ Bulletin 83, U. S. Department of Agriculture. 
tion is given to a single subject, such as cheese making, butter making, fruit growing, market gardening, ctc. John Hamilton, of the Office of Experiment Stations, recommends that different phases of dairying be distributed over three years in the following order: first year-butter making; second year-cheese making; third year-milk production. ${ }^{1}$ The students are required to cover assigned readings each day. One hour in the morning is devoted to lecturing, and three hours in the afternoon to practice exercises in the laboratory or in the field. The tendency of the movable school is to drift into a meeting similar to that of an institute where no real intensive work is done by the student. This of course must be avoided if the object of the school is to be attained.

Contests and the awarding of premiums have long been in use to arouse interest in agricultural education. At agricultural fairs exhibits of all farm products are made and premiums awarded to the owner of the best exhibit. The value of the pure-bred dairy cow is shown. Samples of butter and cheese are scored and premiums awarded. At conventions of many of the dairy associations there are butter and cheese contests. Premiums are arvarded on the basis of the highest score and names of the recipients are published in the report of the association. This has an important educational value because the score card points out the defects of the butter and shows where improvement is necessary. It also has the effect of creating a friendly rivalry among dairymen, resulting finally in the adoption of improved methods.

The state dairy associations have a very important influence in spreading scientific dairy knowledge. The annual

${ }^{1}$ Circular 79, Office of Experiment Stations, U. S. Department of Agriculture. 
conventions of these associations in the principal buttermaking states are well attended. Great enthusiasm is shown at all the sessions. Practical problems of butter and cheese making are discussed. Professors of dairy schools present the most improved methods of dairying that their research work has unfolded. Problems on marketing are discussed. These and other matters discussed at the convention are published in a report and made available for distribution among the dairymen. The dairy convention is largely inspirational and causes people to think about the various problems of the industry. It stimulates reading and study and finally leads to the abandonment of old ways and to the adoption of the new.

The function of the office of the state dairy and food commissioner is not only to prosecute offenders of the law but to prevent violations of the law. The same may be said of all government agencies charged with the inspection of dairy products and their manufacture. In numerous instances inspectors perform the services of instructors at creameries or cheese factories visited, and in some states special instructors are provided by law. In Michigan, dairy meetings that are purely educational are held under the auspices of the Dairy and Food Commissioner. During the year ending July I, I9IO, five such meetings were held throughout the state. Colon C. Lilie, Dairy and Food Commissioner of Michigan, in his report of $1910,{ }^{1}$ says that the law of 1905 " made it the duty of the Dairy and Food Commissioner to foster and encourage the dairy industry of the state, and contemplates that the dairy work shall be largely educational. While the inspectors of creameries and cheese factories and farm dairies are given police powers under certain conditions, the whole spirit of the

1 Page 7. 
law is educational. Inspection under our dairy law, not alone contemplates the enforcement of its provisions, but it implies that instruction shall be given to enable the proper compliance with the law. This same spirit of the law applies in the inspection of farm dairies ". In cases involving sanitation, offenders for the first time are frequently allowed to correct the situation without punishment. Ignorance is often the only reason for violations of the dairy laws, and one inspection in such cases is sufficient to enlighten the offenders. The office of the state dairy and food commissioner is therefore essentially an agency that educates the people in the production of good butter and other dairy products.

The Dairy Division of the United States Department of Agriculture also plays an important part in the dissemination of dairy knowledge both by means of numerous publications and through the coöperation with local agencies throughout the country.

DAIRY INSTRUCTION IN SECONDARY AGRICULTURAL SCHOOLS

The first successful agricultural high school was established in connection with the college of agriculture of the University of Minnesota. ${ }^{1}$ Since then most of the state agricultural colleges have established preparatory courses where the more practical aspects of agriculture are taught. In addition to the high school under the supervision of the agricultural college, county and congressional district high schools are being established in some states. Alabama and Georgia have congressional district schools, while Wisconsin and Michigan have the county school. In the county agricultural high school of IVisconsin the course "extends rver two years and the work includes soils, plants, animal

${ }^{1}$ Circular 106, Office of Experiment Stations, U. S. Department of Agriculture, p. 24. 
husbandry, dairying, rural architecture, blacksmithing, carpentry, and mechanical drawing, for boys; and cooking, laundering, sewing, millinery, floriculture, household bacteriology and physics, home nursing, and home management and decoration, for girls; besides English, United States history, civil government, and commercial arithmetic, for both boys and girls. Tuition is free." 1

At the California Polytechnic School, located at San Luis Obispo, considerable attention is given to dairying. The school owns 3 Io acres of land, and six large and several smaller buildings, including a creamery building 40 by 60 feet, have been erected. The course covers three years' work.

Among other high schools ${ }^{2}$ where dairying is taught mention may be made of the National Farm School at Doylestown, Pa., which also owns a dairy building. In the Mount Hermon School, Northfield, Mass., a special department of instruction in dairying has been organized.

The agricultural high schools and agricultural colleges are becoming more and more articulated into a system because arrangements are being made in many places to admit students into the college upon the successful completion of an agricultural high school course. Another feature that tends to bring unity into agricultural high schools is the fact that the agricultural colleges have taken up the work of training teachers of agriculture.

1 Vide, Circular 106, op. cit.

Ilbid. 


\section{CHAPTER V}

\section{Grading and Judging Butter}

STANDARDIZATION IN GENERAL

Standardization of goods offered for sale is a practice, increasingly used by merchants and dealers, by which commodities are classified according to differences in quality. The possibility of standardizing commodities depends upon the presence of a common factor in reasonably large portions of the supply. There must be considerable uniformity of quality. Cotton, wheat, flour, oats, hay, pork, butter, eggs, and cheese, are among the commodities that have already been standardized by produce exchanges.

The purpose of the standardization of goods offered for sale is to create a convenient and definite basis for trading. It is an expedient that has become well-nigh indispensable in all big markets where large quantities of supplies change hands daily. It is serviceable in connection with the "spot" trading that takes place on the floor of an exchange. It is a prerequisite to "dealing in futures". And it is of the utmost importance to the mass of business deals that are made outside of organized exchanges. The causes that have contributed to the development of the grading system are to be found partly in the desire for speculation, partly in the fact that the method of selling by grade saves time and labor, and partly in the fact that grades are fundamental in the process of arriving at a nicely adjusted market price. 
REASONS FOR THE ESTABLISHMENT OF BUTTER GRADES

As a contributing cause in the development of grades as applied to butter, the kind of speculation that consists of "dealing in futures" is perhaps almost negligible. In wheat the speculative interests had a large share in the establishment of grades. The "dealing in futures", so common in the wheat market, made necessary the "contract grades"; and it was largely because of the speculative motive that the produce exchanges "began to adopt rules to control" 1 grading. In the butter trade, however, "futures" are very inconsiderable. There is speculation, but it consists mostly in buying the goods outright, placing them in cold storage, and holding them for a rise in price. This form of speculation had considerable influence, as will be seen later.

The establishment of grades in butter was probably due in large measure to the need for an expeditious method for handling the business on the floor of the exchange. With the establishment of the "call", which in form is an auction sale, selling by sample becomes out of the question. That method is ton slow, and the necessity of carrying about samples not only entails considerable inconvenience, but would amount in a year to a loss that the business could hardly afford. Selling by grade obviates all these objectionable features, and makes possible putting through a great number of sales in a short time. Under this method. the grade, quantity, price, and time of delivery, are either stated or understood. The sale makes no reference to a particular lot of goods. The thing that is sold is a particular quality of goods. The purchaser need not be concerned about getting his money's worth, because he is pro-

1. H. E. Emery, Speculation in the Stock and Produce Exchanges in the United States, p. 42. 
tected by rules of the exchange which make provision for the inspection of goods that may be tendered him with a view to determining whether or not they are the kind he brught. Such an inspection is absolutely impartial in its decision. This method of buying and selling, in use on the floor of the exchange, rests on the principal of grading and could not be instituted without first establishing grades.

But the primary reason for the establishment of grades in butter is found in the accurate basis for trading that these grades make possible. That is, by grading butter it becomes possible to establish, for each grade, a market price commensurate with quality. And from this fact very important benefits accrue to the trading class.

Butter varies so widely in quality that the utility of the best table butter is very much greater than the utility of the packing stock used principally in bakeries. And this fact should be reflected in the price. Good butter should bring a much better price than poor butter. As far as it is consistent with demand the different qualities of butter should be prevented from influencing one another in the market. A large accumulation of a poor stock of goods will naturally lower the price of this poor stock. And unless the trade draws a sharp line between the utility of this poor stock and that of the finest table butter, the decreased price of the poor stock will also depress unduly the price of the finest butter. Of course there must necessarily be a sympathetic relation between the upper and lower prices; because when poor butter is available it is substituted for good butter in the baking business, and perhaps somewhat for table use. This lessens the demand for the better qualities and has a tendency to depress the top prices. But apart from this sympathetic relation between top and bottom prices, a flood of poor butter, before the time when grades were used as a basis for trading, had an undue tendency to 
depress the whole butter market. The absence of systematic grades as a cause of the depression of all butter prices, was seriously felt in $1874,{ }^{1}$ when the Butter and Cheese Exchange ${ }^{2}$ adopted the plan of grading butter as extras, firsts, seconds, and thirds. At this time quotations were commonly based upon grades indicated by such loose terms as "good to prime", "fair to good", "poor to fair", ctc. There was a wide range of quality that would fall under these terms. And there was a general tendency for the ruling market price that became attached to the "good" quality to attach itself also to "prime", and in general, for the lower grades to have a depressing influence upon prices of the best class of goods. It is complained at this time that an accumulation of a poor stock of goods depresses the entire market due in large part to the lack of a definite system of grades by which prices are allowed to "descend in a regular gradation from prime to poor". The Butter and Cheese Exchange was in position to take action in this matter. By parliamentary methods it could not only adopt the grading system and enforce its use on the floor, but in giving prices to the press it could make the grades the prevailing trading basis throughout the whole trade. With this kind of market machinery it became possible to establish direct relations between the different qualities of butter and the demand for these qualities. Prices for the different grades were allowed to adjust themselves according to the conditions of supply and demand of the different grades. And a fall in the price of the poor stock could no longer unduly depress the whole market.

1 Review of the butter trade by the Urner-Barry Co. in the Report of the New York Chamber of Commerce for 1874, p. 89.

The name of this Exchange was changed to the American Exchange of New York in 1875, and to the New York Mercantile Exchange in 1882 . 


\section{BENEFITS OF GRADING}

Naturally the motive that actuated the members of the Exchange in the establishment of grades was the desire to realize certain benefits. One of these benefits is the maintenance of high prices for the best class of goods. It need not be pointed out that greater profits accrue to the trade when fairly high prices prevail. At the time these grades were established the wholesale butter trade was done on a commission basis more largely than now, and the loss in commission charges resulting from low prices was considerable. But the wholesale dealer who bought his goods outright at a stipulated price, was also interested in maintaining high prices, because he was threatened with failure on a falling market. The speculator likewise was interested in maintaining high prices. It is seen throughout the history of the butter trade that butter was very frequently bought during the summer when prices were low with the purpose of holding it for a rise in price. And it is very natural to suppose that the establishment of grades which aimed at maintaining high prices for the better qualities of butter had the support of the speculator, because of the greater profits coming to him.

The greatest gain, however, comes from the fact that the price of each grade is socialized. This saves a great deal of time to the individual dealer, and eliminates considerable risk. Butter prices are determined daily in all the big cities. Before the existence of the system of grading and the present market machinery it was necessary for each dealer to confer every morning with numerous other dealers before beginning trading in order to ascertain the market price. This entailed a great deal of work, and at the same time involved a great deal of risk, because the information he received was quite unreliable. But with the system of selling by grade under the "call" of the Exchange, these prices 
became pullic and such sales as are there made are truly market prices. The wholesale dealer in making a contract for butter need not stipulate a certain price at which he will take the goods, but can contract to receive the goods at the exchange price, below it, or to pay a premium. It will be observed that in this way a great deal of risk in the wholesale trade has been eliminated. Obviously un a commission basis the dealer takes no such risk, but, as will be pointed out in the next chapter, very little business is now done on a pure commission basis.

The benefits that accrue from the system of grading of course extend to the other class of dealers-the jobbers and retailers - as well as to the producer; because out of grading, together with the organized market, the means of communication, and the press, there is established every day, a price, that is in harmony with the actual conditions of supply and demand. These benefits, in importance to society, are comparable to improvements in the field of production.

\section{CLASSIFICATION AND GRADES}

In the standardization of butter the trade makes use of two distinct steps. The first is known as "classification" and the second as "grading". Both are classifications with regard to quality. The first step, known in the trade as "classification", aims to segregate large quantities that have a tendency to be more or less alike, or in a general way bear the marks of a distinctive character. The New York Mercantile Exchange classifies butter, according to rules issued October I, I9I4, into Creamery, Process, Ladles, Packing Stock, Grease Butter, and Known Marks. The second step. known to the trade as "grading", goes into greater detail, and divides the above "classifications" into grades. These "grades", in use by the New York Mer- 
cantile Exchange, are Extras, Firsts, Seconds, and Thirds. It is clear that grading is a scientific classification according to quality. This step brands the pound, or unit of consumption, with a specific quality. IVhile in the first step) the classification is also made with regard to quality, the object is only crudely attained. It is a division of the supply into large lots or classes, the quality applying merely to the class as a whole and not to its units singly. Some Process butter may be as good or better than some Creamery butter. But as a class, Creamery butter is better than Process. That demand recognizes this difference of class quality, is shown by the difference in the following prices of the best grades in each of the "classifications":

\begin{tabular}{c|c|c|c|c|c}
$\begin{array}{c}\text { Fresh } \\
\text { Creamery }\end{array}$ & $\begin{array}{c}\text { Held } \\
\text { Creamery }\end{array}$ & $\begin{array}{c}\text { State } \\
\text { Dairy }\end{array}$ & $\begin{array}{c}\text { Renovated or } \\
\text { Process }\end{array}$ & Ladles & $\begin{array}{c}\text { Packing } \\
\text { Stock }\end{array}$ \\
\hline $.291 / 2 @ .301 / 2$ & $.25 @ .26$ & $.27 @ .28$ & $.221 / 2 @ .231 / 2$ & $.191 / 2 @ .20$ & $.171 / 2 @ .18$ \\
\hline
\end{tabular}

(From the New York Times, Mar. 16, Igr5.)

The "classifications" and "grades" are, as previously stated, determined by organized markets. In Elgin, they are determined by the Elgin Board of Trade; in Chicago by the Chicago Butter and Egg Board; in New York by the New York Mercantile Exchange: in Boston by the Boston Chamber of Commerce. There is a disposition among all these bodies to conform to a common practice in this matter of establishing "classifications" and "grades". The reason for the tendency toward uniformity is not to be explained, however, merely as a result growing out of motives of the trade: such as improved trading facilities, or the establishment of prices that have the same significance in all markets; but must be explained on the ground that the terms specifying "classifications" and "grades" must always 
truly characterize the supply. Conditions in the field of production, including transportation and cold storage, always determine the class terms used in the trade. "Grades" are not as closely related to production as "classifications", but are nevertheless largely conditioned by it, because it is the range of quality in the supply that determines the number of "grades" and the range of points to be assigned each grade.

\section{THE EVOLUTION OF CLASSIFICATIONS}

An historical study of the trading rules adopted from time to time by produce exchanges, and a review of press quotations, reveal changes in class terms that are almost parallel with changes in production. Of course the change in production necessarily always precedes the change of the class terms in the trading rules of exchanges. The press ${ }^{1}$ in many parts of the country, however, is frequently delinquent as to the adoption of the terms used officially. There is great variation in the use of grade terms in the daily press, and a study of press quotations alone shows only vaguely the intimate relation of "classifications" to the history of production.

The history of "classifying" butter may be divided into three periods. In the first period butter was classified with regard to its maker; in the second with regard to geographical producing areas-first, a small locality, then, a state, and after this, groups of states, as Eastern or Western: in the third with regard to its process of manufacture.

Before the days of the big markets that have developed concurrently with our big cities, classifying and grading butter was a very simple process, and indeed of little con-

1 This cannot apply to publications of the type of the New York Produce Review and American Creamery, published by the UrnerBarry Co. 
sequence. Then, butter was consumed where it was produced; and the distributing process, now of such tremendous importance, was not a factor. For buying and selling was among neighbors or through the grocer of the town. In many cases the consumer knew the producer personally. He knew the habits and personal characteristics of the dairywoman, and could form a close estimate as to the type of butter that she would be likely to produce. And of course a number of trials of her butter would stamp it finally with its own peculiar quality. When this close relation between consumer and producer no longer existed by reason of the growth of the town, there was still a tendency to identify the butter with its maker. In New York City as late as 1858 , according to a statement made by the $N e w$ York Tribunc and reprinted in the Ohio Agricultural Report ${ }^{1}$ for that year, butter in many cases was still associated with the maker, "some dairies bringing two to eight cents per pound more than others from the same neighborhood" because of "the difference in quality resulting from different degrees of skill and care in the makers". And even to-day the "classification", known to the trade as Known Marks, is based on the same idea. For instance, the quality of the butter manufactured by the Strawberry Pt. Creamery of Strawberry Pt., Iowa, is generally known to the trade, and the name of the maker is synonymous with a specific quality. There are a number of such manufacturers who have won a reputation for uniformity of a specific quality ,and whose product is thus enabled to be sold under a Known Mark. The basis of the identity of the maker is still used in sections of the country remote from towns of any size, and much of the farm-made butter, by reason of the fact that it is largely consumed in local mar- 
kets, is still bought and sold on the basis of the identity of the maker.

Before the days of dairy associations, butter-making was not only entirely domestic and therefore extremely individualistic, but there was no organized means of putting into general use the best methods then known, and as a result there was a general lack of uniformity in the quality of the product. There was no commun factor in different lots of butter. Each lot was itself a class. Obviously under these circumstances the only basis for classification was the association of the butter with its maker.

As butter was produced more and more for the market instead of for local consumption, certain localities developed exceptional skill and uniformity of method. This meant that the product from one of these localities was stamped with a peculiar quality throughout its whole extent. Examples of such localities in dairy history are Orange County in the State of New York and Franklin County in Vermont.

Before I840 very little of the butter from Franklin County went to Boston, but practically all its surplus butter, together with cheese and dressed hogs, was taken to Montreal. With the completion of the Vermont Central and Vermont \& Canada railroads in I, 850 , Boston began to seek the butter of Franklin County. In 1854 the Vermont Central railroad began running its butter cars supplied with ice through the county, the town of St. Albans becoming a very important shipping center for Franklin County butter. ${ }^{1}$ From this time to the advent of the creamery, Franklin County butter served as a standard for quality in Boston.

What was true of Franklin County was perhaps more pronounced in Orange County. This county sent its butter

${ }^{1}$ Vermont Agricultural Report for I872, pp. I58, I59. 
to New York City, and was famous for producing good butter. Butter from this county could command prices higher than butter from other localities, and it was a trich of the trade to send butter from the outside into Orange County to have it christened and sold as butter from this locality. ${ }^{1}$

Butter shipped from these two counties was doubtless fairly uniform in quality, and as a basis for classifying butter, these localities, and probably others, served a useful purpose in the trade. Of course the classification was crude and quite unfair to other sections of the country that had learned to make good butter; for the selling of the product was in some degree dependent upon the reputation of the locality, a kind of good-will that only a few localities possessed.

During the 40's and 50's there were economic forces at work that made the growing of wheat and the raising of sheep in the eastern states less profitable than dairying. In a general way this was due to the rapid western expansion and the growth of cities and manufacturing towns throughout the New England and Middle Atlantic states. These forces had much to do with the decline of the wool-growing industry in Vermont and of the growing of wheat in New York: and caused at the same time an increased dependence upon dairy products throughout these states, as well as throughout other eastern rural sections. Under this economic pressure there is little wonder that buttermaking throughout the whole state of Vermont was standardized so as to produce a quality, so uniform, that it was recognized in the market as having a distinctive character. Climate probably was a factor in that it favored this section of the country, and its topography, with its many clear

1 Ohio Agricultural Report for 1858 , pp. 297, 298. 
springs and streams, was conducive to the production of good milk, and provided ready means for cooling and setting it, as well as for the preservation of the finished product. Some of these advantages were absent in New York State. But here too we find that the market recognized a quality that was no longer limited to the boundary lines of Orange Connty, but was made co-extensive with the whole state. In addition to economic pressure, the development of this state-wide uniformity in the quality of butter was unquestionably hurried along by the persistent agitation for scientific methods by agricultural societies ${ }^{1}$ and later by the state dairy associations. The present dairy association of Vermont ${ }^{2}$ has had a continuous history since I869, and that of New York State since I877.

As late as I870 the name of Orange County was frequently applied to all butter coming from the southern tier of the counties of New York State. ${ }^{3}$ But for some time before this butter from this territory was also generally spoken of as New York State in contrast with Western, which at first specified butter from the "Western Reserve", or from the region principally covered by the state of Ohio. The following statement ${ }^{5}$ of prices illustrates not only the fact that the trade classified the butter coming into the New York market on the basis of wide geographical producing areas, but it also shows that the basis at this time was not altogether an arbitrary one; for the quality was probably fairly well reflected in the prices, which show quite a difference :

${ }^{1}$ Transactions of the N.Y. State Agricultural Society, 1845, p. 59.

${ }^{2}$ Bureau of Animal Industry, Circular No. 204.

${ }^{3}$ Essay by O. S. Bliss in Vermont Dairy Association Report for 1870.

4 This is a small section of northeastern Ohio ceded to the State by Connecticut in I800. Vide, W. R. Shepherd's Historical Atlas, p. I96.

- New York Chamber of Commerce Report for I873, p. 223. 


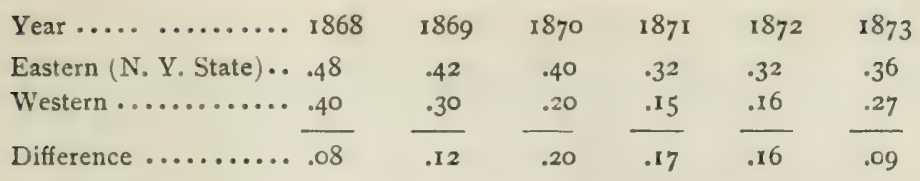

But there came a time when the classification of butter based on producing areas lost its significance. That time was when the factory system became established all over the country. This, by introducing uniformity of method, brought uniformity of quality into the product. The first butter factory in New York dates from about the year I86I; ${ }^{1}$ and through the 70's factories spread through the West. As a factor in the New York market the stock from the western factory was not felt until about 1876 , when the region around Elgin, Ill., developed into a famous butter-producing area, and during the winter of 1877 , sold its product in New York at " 38 to 40 , while best New Iork State early made creameries sold at 30 to 33c." 2 The work of dairy education, and the agitation of dairy associations were beginning to be felt. The West by this time had not only established the factory system, but was adopting new methods of feeding. They began winter dairying, and feeding corn meal. Of course transportation and refrigeration after I 869 were also greatly improved. "Distance and time are overcome and the cost of transit from the extremities of production to the centers of consumption are now less than formerly existed between the outlying counties of this state and our city markets". The terms Eastern and IVestern were used to quote prices long after they had lust their significance, or at least until it was nec-

${ }^{1}$ X. A. Willard, Practical Dairy Husbandry, p. 237.

2 "Review of the Butter Trade" by the Urner-Barry Co. in the N.Y. Chamber of Commerce Report for 1877 , p. II6.

3 Idem, p. II 5 . 
essary to make a number of exceptions, like "Elgin", ctc. Prices quoted therefore as Eastern and Western after 1876 are frequently misleading. The following statement ${ }^{1}$ of prices may be taken as substantially correct with regard to the significance of the class terms; and it is noted that there is no longer the great difference in price, and therefore not the difference in quality between Eastern and IVestern, that obtained before 1877 :

\begin{tabular}{|c|c|c|c|c|c|}
\hline Year .............. & 1882 & I 883 & 1884 & 1885 & I 886 \\
\hline Eastern............ & $.291 / 2$ & .26 & $.24 \frac{1}{3}$ & .22 & $.231 / 2$ \\
\hline IVestern ............ & .28 & .24 & .22 & .22 & $.211 / 2$ \\
\hline Difference ........ & $.011 / 2$ & .02 & $.02 \frac{1}{2}$ &.$\infty 0$ & .02 \\
\hline
\end{tabular}

Although these class terms were of little significance as these prices show, the New York Mercantile Exchange continued to carry them until as late as $1886 .^{2}$ That is, creamery and dairy butters were classified as Eastern Creamery and Dairy and IVestern Creamery and Dairy. The Boston Chamber of Commerce, however, does not use these terms in its annual report for I886, and classifies butter strictly with regard to the process of manufacture, as follows: Creamery, Imitation Creamery, Dairy, and Ladle Packed.

The abandonment of the geographical producing area as a basis for classifying butter, and the substitution of the prccess of manufacture, was of course inevitalle for the simple reason that the former had lost its significance and could no longer characterize the supply: while the latter basis is significant, and actually does classify large lots of butter with regard to quality.

The Boston Chamber of Commerce, in its annual report

1 Ninth Annual Report of the New York Dairy Commissioner, pp. I38-9.

2N.Y. Mercantile Exchange, Butter Rules, adopted March 23, 1886. 
for I9I3, classifies butter into Creamery, Imitation Creamery, Ladle, Dairy, Renovated, Packing Stock, Grease, and Known Marks. The New York Mercantile Exchange, in its rules adopted October I, I9I4, uses the same terms except that the classes, Imitation Creamery and Dairy, are omitted, and for Renovated the word Process is used, this being synonymous with Renovated.

The definitions ${ }^{1}$ of these classes are as follows:

Creancry-Butter offered under this classification shall have been made in a creamery from cream separated at the creamery or gathered from farmers.

Process-Butter offered under this classification shall be such as is made by melting butter, clarifying the fat therefrom, and rechurning the same with fresh milk, cream or skim milk, or other similar process.

Ladles-Butter offered under this classification shall be such as is collected in rolls, lumps, or in whole packages and reworked by the dealer or shipper.

Packing Stock-Butter offered under this classification shall be original farm-made butter in rolls, lumps or otherwise, without additional moisture or salt.

Grease Butter shall comprise all classes of butter grading below thirds or of packing stock grading below No. 3 as hereinafter specified, free from adulteration.

Known Marks shall comprise such butter as is known to the trade under some particular mark or designation and must grade as Extras or better if Creamery or Process, and as Firsts or better if Ladles in the season when offered unless otherwise specified. Known Marks to be offered under the call must previously have been registered in a book kept by the Superintendent for that purpose. If Process the factory district number and state must be registered.

Imitation Creamery, a classification still used by the 1 Butter Rules, adopted October I, I9I4. 
Boston Chamber of Commerce, refers to butter churned by the dairyman and disposed of by him in unsalted and unworked condition. The dealer salts, worlss and packs it for the market. This product has dwindled to an insignificant quantity, and is no longer a factor in the market.

Dairy Butter, another classification still carried by the Boston Chamber of Commerce but no longer by the N. Y. Mercantile Exchange, is butter made, salted and packed by the dairyman, and offered in its original package. In other words, it is the product familiarly known as farm-made butter. This class also is rapidly diminishing in importance in big seaboard markets like New lork City. The reason for the disappearance of dairy butter from the big marlicts is the invention of the new manufacturing processes. The most important of these is the creamery which produces a large supply of uniform quality. This supply is naturally more merchantable than a promiscuous supply like the dairy product, and is easily ahle to crowd out the poorer classes of butter. But by no means unimportant is the renovating process which collects all dairy butter not consumed locally, melts it at a low temperature, and, if the law is complied with, works it over, and packs it for the market without the use of deodorizing chemicals or injurious preservatives. This process puts transformed dairy butter on the city market under the trade name of "Renovated" or "Process" butter. The importance of this class is seen in the amounts ${ }^{1}$ that have been prodiced during the period, I903-r9I4:

${ }^{1}$ Report of the Internal Revenue Commissioner for I9I3, p. I28. 
Year.

Production in Pounds.

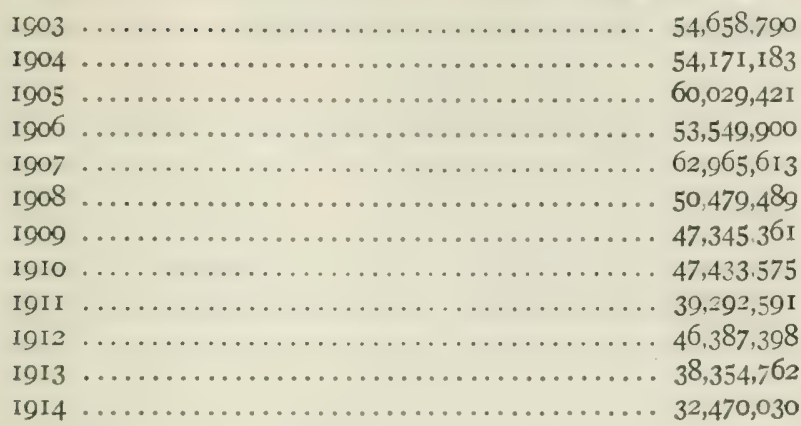

From the classifications in use at the present time in all the big butter markets it is seen that they are based on the manufacturing process. Packing Stock and Grease Butter must be regarded as deteriorated classes, having their origin in the other classes. Known Marks, however, is a testimony to the importance of the "identity of the maker", and is the only class not based on the process of manufacture.

\section{THE DEVELOPMENT OF GRADES}

In the history of "grading", the second step in the standardizing process, there is noticeable a gradual refinement in the use of terms and definitions.

Already in $1874^{1}$ the Butter and Cheese Exchange of New York began the use of the terms, Extras, Firsts, ctc., and these terms for the first time were used as a basis for quoting prices in the Producers' Price Current ${ }^{2}$ in the issue of March 3, 1883 . Before this time more or less loose terms were employed, such as fancy, choice, prime, good,

${ }^{1}$ Report of New York Chamber of Commerce for 1874, p. 89. According to letter from F. G. Henry, Supt. of New York Mercantile Exchange, dated March 23, 1915, these terms were adopted in 1884.

${ }^{2}$ Published by the Urner-Barry Co. 
fair, and common. This is the practice now in connection with a class of butter that is not officially recognized by the exchange.

An important step forward was taken when the grades were defined. The elements into which the grade concept was resolved are the properties or characteristics of the butter as it is found in the market. They are Flavor, Body, Color, Salt, and Package. From the beginning each of these characteristics was defined for each grade. For instance, for the grade of Extras, "Flavor.-Must be sweet. fresh and clean for the season when offered if creamery. or sweet, fresh and reasonably clean if process or ladles." For the grade of Thirds, "Flavor.-May be off flavored and strong on tops and sides." 1 The idea of subdividing grades into these characteristics and defining them for each grade came into use probably about the same time as the grade terms, Extras, etc.

In 1905 both the New York Mercantile Exchange and the Boston Chamber of Commerce adopted the principle of scoring. This feature is now used by all the big organized markets. They all assign the same weights to the grade elements. The weights are distributed according to the importance of the characteristics as follows:

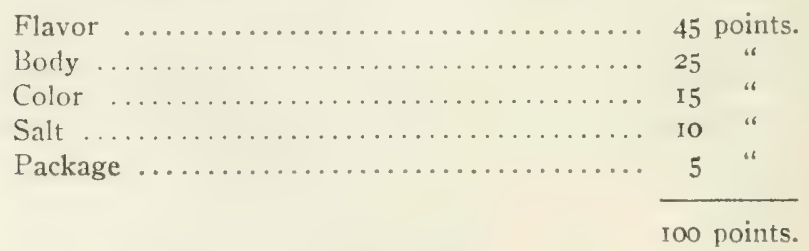

It should be mentioned that the idea of scoring did not originate in the trade, but that it developed in connection

1 New York Mercantile Exchange, Butter Rules, adopted October I, 1914. 
with educational contests. In IgOI there was as yet no agreement among the American dairy associations as to the importance of the various characteristics of butter, and in a letter ${ }^{1}$ to the Iowa State Dairy Association held during that year, Maj. Henry E. Alvord, then Chief of the Dairy Division of the Department of Agriculture, argued that body was as important as flavor, and proposed that the weights to be assigned to these two elements should be 40 for each. Of course there were differences of opinion as to the importance of the different grade elements. By I904 it had become customary ${ }^{1}$ to allow 45 points to flavor, but even at this time there was considerable variation in this matter at butter contests over the country. By 1905. however, the trade was generally in accord as to the relative importance of the grade elements.

\section{PHILOSOPHY OF GRADES}

The number of grades depends upon the range of quality. The consumer must recognize an appreciable difference in passing from one grade to the next. This principle is applied in assigning a total score of not less than 9I points to the grade, Extras, and then making a difference of 4.5 , and 7 points in the successive grades of Firsts, Seconds, and Thirds.

The New York Mercantile Exchange makes use of a sliding scale of three points to meet changes in the quality of the supply caused by changes in the seasons. Butter to grade Extras in the summer must score 93 points, but to grade Extras during the winter need score only 9I points. When the minimum score of Extras is changed, there is a corresponding change in the total score of the successive

1 Published in the New York Produce Review and American Creamery under date of Nov. 6, I9or, pp. I2-I3.

'Agricultural Yearbook for 1904, p. 418. 
grades; because between the successive grades there must always be a difference, according to the rules, of 4,5 , and 7 , respectively. There have been objections to this sliding scale from public quarters on the ground that it is used to manipulate prices. This charge of course is entirely unfounded. The scheme is a good one and is in full accord with the underlying principle of grading. In the winter the whole supply of butter is of poorer quality than that of the supply in the summer, and in order to have a system of grades that serves truly as a trading basis, there must be enough flexibility in the system to allow changes when changes in the quality of the supply occur. The sliding scale makes available a larger supply of Extras in the winter time, and has a tendency therefore to keep top prices down. This is a benefit to the consuming pullic, but is opposed to the interests of such producers whose butter scores, summer and winter, 93 points and above. But the scheme favors the mass of producers whose best butter has a tendency to fall below 93 points in the winter time.

The division of the grade term into elements of Flavor Body, Color, Salt and Style or Package, is possible because these elements are the peculiar characteristics of butter. In other words they distinguish butter, and may be regarded as objective elements.

But the weighting of these elements rests upon sul)jective considerations. The consumer's tastes and wishes with regard to all these elements are estimated. It is found that the consumer cares more about the flavor of butter than about any of the other elements. Next in importance is the body, sometimes called grain or texture. The consumer wants to recognize a decided difference between the texture of butter and that of grease or lard. The American consumer desires considerable color and salt, while in Europe these are not wanted. Reasons for scoring export 
butter differently from domestic butter are therefure apparent. It will be seen therefore that the relative weights assigned to the grade elements, if properly judged, correspond to the relative importance attached to these elements by the consuming public.

Scoring butter as a method of determining butter values has in it a good deal of what may be called the human equation. The butter judge must fully comprehend the relative importance that the public attaches to the respective grade elements. In addition, his judgment of butter must be keen. It is a well-established principle in psychology that continued attention to a given stimulus will tend to diminish the intensity of the sensation. This is what actually does happen to the butter judge. After having tasted and smelled butter for some time, his senses of taste and smell become duil and it is necessary to stop and eat an apple or take a drink of a kind that has a distinctive odor and taste. This change sharpens the sense of smell and taste for butter, and enables him to proceed in the work of judging. But in spite of the fact that judgment is a large factor in scoring butter. the difference in the total scores of butter as judged by different expert judges is not great, and for commercial purposes, not important.

\section{THE USES OF GRADING}

Grading is not only used in the trade, but is used for the perfimance of experiments in butter-making and in educational and other contests.

Priducers and dairy schools conduct experiments for the jurpe of improving the quality of their butter. The results of the experiments can only be determined by the scre that an expert judge will give the butter produced. For instance, the butter-maker may be anxious to determine the effect of pasteurization of the milk upon the quality of 
butter. In connection with an experiment ${ }^{1}$ conducted for this purpose, it is complained that the score may not be a correct measure of the quality of the butter due to the fact that the personal element makes it impossible to " place the score on an independent basis similar to weights and measures". The very nature of the problem of course makes it impossible to test the quality of the butter with the same scientific exactness that can be observed in testing mechanical forces. But that scoring is very helpful in experimental work in that it points out defects which may be speedily remedied by changing methods of production, is everywhere admitted.

Scoring is also used for the purpose of educating buttermakers in the art of making good butter. In this connection the butter judge is the diagnostician of poor butter. He points out the defects by scoring low those grade elements that need improvement, and adds remarks indicating the causes of the trouble. Such educational work is usually carried on under the auspices of dairy associations with the coöperation of state and federal dairy officials. In Michigan, during the year 1910, "I,O00 samples of butter and 288 samples of cheese were scored " ${ }^{2}$ by experts from the Dairy Division of the Lnited States Department of Agriculture.

${ }^{1}$ University of Wisconsin Experiment Station, Bulletin No. 69.

${ }^{2}$ Report of Michigan Dairy and Food Commissioner for I9IO, p. 9. 


\section{CHAPTER VI}

\section{History and Development of the Organization of the Butter Market}

\section{EARLY CONDITIONS}

IN the Vermont Agricultural Report for ${ }_{1} S_{72} 2^{1}$ there is an unique account of a corner in butter that affected the Boston market. It runs as follows:

In 1856 B. F. Rugg . . u undertook to carry out a plan for controlling the Boston butter market . . . to keep back a large quantity of it has the effect to advance the price. This Mr. R. well understood . . he made his arrangements at the various banks in the county ${ }^{2}$ for an unlimited supply of means of credit. He began buying toward the last of June when butter was low, and quietly stored it away in cellars. This he continued to do through July and August, sending to market only a small supply from week to week.

Before August was past in consequence of keeping this large amount out of the market, butter began to advance in price. Mr. Rugg continued to buy and when he could buy no more, advised the farmers that still had butter to hold on for higher prices. This they were only too willing to do on a rising market, and their prices became so extravagant that buyers cuuld not buy. Now he had them. Boston had to submit to St. Albans. ${ }^{3}$ The profits of this little speculation amounted to the snug little sum of $\$ 18,000$; so says the gentleman himself and nobody doubts it.

1 P. I6I.

${ }^{2}$ Franklin County, Vermont.

${ }^{3}$ The county-seat of Franklin County, Vermont. 353] 
This story is interesting because it shows the absence of an efficient market organization. At that time transportation and refrigeration facilities had been only crudely developed. There were then no organized butter markets, such as boards of trade or exchanges where receipts and prices of butter at other markets could be tabulated, and where the buying and selling would result in a market price that was based on the conditions of supply and demand of the entire country. In consequence of this situation there was nothing like the sensitive fluidity that exists to-day in the movement of butter to points of high prices.

Historic references to methods of marketing butter that are scattered through agricultural and dairy reports show that during the 50's, 6o's and 70's some interesting practices prevailed in different sections of the country.

Before 1840 very little butter found its way to distant markets during the summer from Franklin County, the historically famous butter-producing region of northern Vermont. ${ }^{1}$ The butter made during the summer was packed in tubs, preserved with salt or brine, and stored in cellars. When winter came the butter with other produce was loaded on sleighs and taken across the frozen St. Lawrence to Montreal. About a week was consumed to make this trip and sell produce valued at about one hundred dollars. With the extension of the railroad through this county and the running of butter cars supplied with ice in I $_{54}$, there came to Franklin County that revolutionary change in the methods of marketing its produce that comes to every rural community when it is reached by a railroad. Butter could now be sent to Boston and other markets during the summer. It was no longer stored because of the lack of trans-

${ }^{1}$ A full account of the methods of marketing butter that prevailed in Franklin County at that time may be found in the Vermont Agricultural Report for 1872 , pp. 158-160. 
portation facilities. From about 1850 to well into the 70 's there prevailed through the northern part of Vermont the peculiar custom of dealers meeting the farmers at the stations along the railroad on the day the butter car passed through these points. It St. Albans this happened to be Tuesday. In amusing account of the market day in this town runs as follows:

St. Albans presents a lively appearance on Tuesday during the spring, summer and fall. From early morn till near noon teams laden with butter and cheese are coming in from all directions and as they file in down Lake street toward the depot, that street becomes packed with one dense mass of horses and wagons. Teams are hitched at every post on Main Street; the hotel barns and yards are full; the hotels are full, and the farmers-I mean their pockets-are full. Butter is king.

The scene when the buyers, crowding in among the teams in the streets, are engaged in buying the butter and cheese of the farmers, is a very exciting one.

The method of marlieting butter that prevailed in the regions supplying New York City was different. Before the days of railroads it was customary for the farmers along the Hudson river to entrust captains of river barges with the transportation of their butter and with making favorable sales. ${ }^{1}$ The practice that prevailed on these river barges was later followed on the railroads running through the Orange County district, from which butter was shipped twice a week, and on the New York, New Haven and Hartford Railroad between Bridgeport, Conn., and New York City, over which a market car was run once every week. ${ }^{2}$ The captain, whether of a barge or freight car, attracted

\footnotetext{
1 X. A. Willard, Practical Dairy Husbandry, p. 246; essay by O. S. Bliss in the Report of the Vermont Dairy Association for 1872.
}

${ }^{2}$ Idem, p. 52 . 
regular customers who soon became acquainted with the quality of the goods he had to sell. He sold at the highest prices pussible, and charged a commission of from one to two cents a pound for his services. The remainder of the proceeds he returned to the producer. He also submitted offers made by dealers from New York to factories for large lots of butter. The captain, therefore, performed the very important services of a middleman.

In regions less favored by transportation facilities butter was sold to the country grocer or merchant who assorted qualities and colors, packed it, and shipped it to wholesale houses of the city. Butter in the eastern states was frequently marketed in this manner, ${ }^{1}$ and from the Viestern Reserve of Ohio from about I 855 for a number of years it was the only way. ${ }^{2}$ Butter from Ohio at that time was largely sent to California.

Of course for local consumption butter was sold either directly to the consumer or to the village grocer who was the only middleman in the distributing process.

Aside from these different practices there was some direct dealing between dairymen and consumers living in big cities. This developed, however, only when the farmer made butter of excellent quality and was fortunate enough to find discriminating customers. Of the total amount of butter consumed in the big cities, the part distributed by direct dealing must have been only a small percentage.

DIRECT CONSIGNMENT TO COMMISSION MERCHANTS

Late in the 60's "some of the producers sent their butter and cheese directly to the Boston market, but not a large. number of them ". At that time butter makers began more

${ }^{1}$ F. D. Douglas in Report of the Vermont Dairy Association for I87I.

${ }^{2}$ Ohio Agricultural Report for 1858 , p. 298.

${ }^{3}$ Report of the Vermont Dairy Association for 1872 . 
and more to consign their product directly to commission merchants. But in the absence of a well-established market price, this method proved to be quite unsatisfactory to the producer. Nany complaints to this effect were made at that time against the commission merchants. For instance, at Elgin, I1l., " previous to the organization of the board in IS 72 , the goods had been disposed of on commission, and by the time the freight, cartage, storage, shortage, and several other ' ages' known to the trade, had been deducted from the shipments, the manufacturers found that the accounts for sales were very short, and occasionally they found themselves indebted to the commission man, and they had nothing to pay the milkman or their help ". " The dealers of the city had of course a decided advantage over the producers in the country. The former were fairly well informed as to prices, while the latter were groping in the dark. Under these circumstances it was an easy matter for the commission man to make exactions that were perhaps justly denounced as unscrupulous. But it must be remembered that the trouble lay not alone with the market machinery. Manufacturers generally had not yet learned to make regularly butter of good quality; and when short returns were made by commission men for this reason, they were of course unjustly accused.

This more or less chaotic condition of the trade led to the establishment of the organized markets, known as boards of trade or exchanges. Of these there are two types. the producers' exchange and the middlemen's exchange.

\section{THE ESTABLISHMENT OF PRODUCERS' EXCHANGES}

The earliest producers' exchanges where dairy products were sold, were established primarily for the sale of cheese.

1 "Report of the Illinois Dairymen's Association" in the Transactions of the Department of Agriculture for 1880, p. 352. 
At Utica, N. Y., there developed an active market for cheese shortly after the cheese factories began to operate in 1850 . Later an association was formed known as the Central New York Farmers' Club and the Board of Trade. Membership fees were charged, and "the bulletin was made up in the morning, giving the receipts, price abroad by cable, highest quotations in New York, etc." 1 In I87 I, a similar market was organized at Little Falls, N. Y., where the farmers frequently formed combinations to defy the "rings" of dealers. The movement spread to IVisconsin." Boards of trade were established at various places throughout the state. At Sheboygan Falls a board was organized in 1873 . "During the first two years of the existence of this board most of the cheese was shipped to Chicago or New York on consignment, but the claims for 'short weights', 'off stock', ctc., were so numerous that manufacturers 'kicked' severely against that method of doing business, and therefore established a system of selling their goods, to be paid for when delivered at the railroad station or dock, where also the weights were to be tested. Since that time the business has almost entirely been conducted on that principle, as there are from eight to fifteen buyers ready to buy each sale day, representing London, Liverpool, Glasgow, Chicago, New York, Boston, St. Louis, New Orleans and other southern markets, and no cheese goes on commission unless it is some poor and off stock." ${ }^{3}$ The idea of establishing a producers' market "where the manufacturers could find protection against the grasping commission men,

${ }^{1}$ Report of the Vermont Dairy Association for 1872 , p. 46; Report for 1873 , p. 145 .

2 Vide Bulletin 23I, Wisconsin Agricultural Experiment Station, prepared by H. C. Taylor, W. A. Schoenfeld and G. S. Wehrwein for the history of Wisconsin cheese boards.

'Report of the Wisconsin Dairymen's Association for 1882, p. I30. 
and where the latter might obtain protection" "against exactions of the former, was carried over from the cheese trade into the butter trade. Of all such markets, whether established primarily for the sale of cheese, or butter, or both, the Elgin Board of Trade is by far the most important. Both butter and cheese are sold on this market, but it is known principally as a market for butter. The following account ${ }^{2}$ relates the circumstances under which the Elgin Board of Trade was organized:

By 1872 there were in the vicinity of Elgin, Illinois, about twenty factories, operated on the coöperative plan. But these factories had no established market for their product, except through the commission men in different cities.

This way of selling their product was very unsatisfactory, and they commenced to plan for a better way to market their butter and cheese.

In March, 1872 , there gathered together in Elgin the owners and representatives of nineteen factories and organized the Elgin Board of Trade.... A producers' market was established, where both the buyer and seller could come together once a week and buy and sell the product of the factories represented by the members of the association, instead of consigning on commission as heretofore.

Of course it was a hard struggle to persuade the dealers and commission men to attend the board meetings, and to buy the product at a price before shipping, and less determined men would have been discouraged. But with the assistance of some of the promoters who came forward and bought both butter and cheese when the dealers failed to attend and buy the offerings, the dealers and commission men were soon brought to see that the Board was not only in the interest of the producer, but the dealer as well.

1 "Report of the Illinois Dairymen's Association" in the Transactions of the Department of Agriculture for I880, p. 352.

${ }^{2}$ From the Fortieth Annual Report of the Elgin Board of Trade. 
By February, 1879 , the board had become so well established, and both butter and cheese were of such a high standard of quality, known in every consuming market in the country as well as in Europe, as Elgin butter and cheese, that it was thought best to incorporate under the laws of Illinois. ... The object for which the corporation was formed was "to maintain commercial exchange, to promote uniformity in the customs and usages of merchants, to inculcate principles of justice and equity in trade, and generally to secure for its members the benefits of coöperation in their legitimate pursuits."

At first the buyer and seller would meet in the exchange room, and after completing their deal, report their trade to the secretary, which sale was known as a regular sale. But the offerings and transactions soon became so large that a regular call board was established, where the name of the factory could be written down upon a large blackboard, giving the number of tubs of butter or boxes of cheese offered, and if the seller chose to do so he could offer at a price or at his option.

The buyer could then take at the price offered, or make his offer, and in that way they would get together on the price, and establish the quotation for Elgin butter and cheese.

\section{THE ESTABLISHMENT OF MIDDLEMEN'S EXCHANGES}

At the time this producers' exchange was being organized, a movement to organize middlemen's markets was also in progress. In New York City the commission men dealing in butter and cheese were affiliated with the Produce Exchange prior to 1873 , where up to that time these trades received very little attention. During that year, in compliance with a request made by the dairy commission men, the Exchange included in its daily produce reports the receipts of butter and cheese at New York. ${ }^{1}$ Prior to IS73, the butter and cheese dealers conducted their business without any formal trade rules; but during that year they were

${ }^{1}$ Annual Report of the N. Y. Produce Exchange for 1873-1874, p. 28. 
invited to prepare rules to govern their branch of the business on the Exchange. ${ }^{1}$ Several meetings were held to discuss this matter, but owing to friction with members of other trades on the floor, ${ }^{2}$ the butter and cheese dealers decided to sever their connection with the N. Y. Produce Exchange, and organize a market of their own under the name of the Butter and Cheese Exchange of New York, where the dairy trade would receive the attention that its growing importance deserved. The name of this exchange was changed several times, and in 1882 assumed its present name, The New York Mercantile Exchange.

The objects of the Exchange, as stated in its charter, are " to foster trade; to protect it against unjust or unlawful exactions; to reform abuses; to diffuse accurate and reliable information; to settle differences between members, and to promote among them goodfellowship and a more enlarged and friendly intercourse".

Since the establishment of the New York Mercantile Exchange similar middlemen's markets for the sale of butter and cheese have been organized in other cities, although not usually as a separate institution. In Boston and Cincinnati, for instance, the butter and cheese trades are a department in the Chamber of Commerce. On the Pacific Coast these markets came of course at a much later date than in the eastern cities. By I903, some of the Pacific Coast cities had their organized butter markets; but San Francisco at that time was still experiencing the troubles arising out of the plan of leaving the task of quoting accurate prices to the newspapers whose reporters "are likely to be cajoled and misled according to the wishes of the particular dealer as it affects his condition ". 3 This is the plan usually fol-

${ }^{1}$ Report, op. cit., p. 30. ${ }^{2} N$. Y. Mercantile Exchange Handbook, p. I8

${ }^{3}$ From the Elgin Dairy Report, June 29, I903 (copied from the Dairy and Produce Review of San Francisco). 
lowed before the organization of the butter market occurs. The plan does not command the respect of either the producer or the dealer, and, as it is thought that it does not furnish a reliable trading basis, it is very unsatisfactory.

\section{CAUSES FOR THE ORGANIZATION OF EXCHANGES}

The movement that resulted in the organization of the producers' and middlemen's markets was due to several causes. One of these was the struggle between producers and commission men concerning the division of the price, and another was the great need felt by both classes for a reliable trading basis.

The struggle between producers and commission men concerning the division of the price paid for butter by the jobbers or retailers, is not only evident from complaints and bitter arraignments appearing in reports of dairy associations, but the basis for the trouble is also admitted at times by the dealers themselves. For instance, the San Francisco Produce Review makes the following statement which was copied by the Elgin Dairy Report of March 2, I903:

The wholesale dealers in butter and eggs of Los Angeles, Cal., through their organization, The Produce Exchange, have decided in the future to charge eight per cent commission on consignments instead of five. It is maintained by them that at five per cent they can only conduct business at a loss and make up by "stealing," as one dealer puts it, out of the sales account or on weight. It is thought that the move will have the effect to change business from consignments on commission to direct sales by shippers under contracts.

The trading class of Los Angeles, Cal., has been only recently passing through the same changes of marketing methods that the dealers in eastern cities had gone through much earlier. In 1903, the wholesale dealers in Los An- 
geles were still receiving butter on the commission basis, while dealers in eastern and middle western markets, in I $896,{ }^{1}$ were already generally receiving butter on the " contract" basis, which is an agreement between the producer and dealer to use the quotations of some exchange as a basis for trading. While five per cent was the usual charge by commission men everywhere at the time this method was principally used, it was probably a very common practice among them to make deductions on account of loss in weight, or storage, etc., and by such extra charges raise their income considerably above five per cent. Of course it must not be forgotten that a good deal of the butter made at that time was of a poor quality, and that the dealer in such instances was in no way to blame for the small returns made to the producer.

The organization of the Elgin Board of Trade may be regarded as a protest against this kind of dealing and as a means of protecting the producer. What its founders specifically wanted was to make the dealers buy on the manufacturers' terms. They wanted the dealer to come to the producer to make the purchase, and pay for the butter f. o. b. shipping place. Doubtless the action taken by the producers in the Elgin district served to stimulate the wholesale dealers to greater activity in organizing the butter markets. So that it may be said that the development of these organized markets, both the producers' and middlemen's markets, was due in large measure to the fight that was waged by the producers against the commission men.

The great need that the butter trade felt in the 7o's was for an accurate trading basis, or correct market prices for the various qualities. From a broad economic point of view this was a force inherent in the trade that would sooner

${ }^{1}$ Report of the Elgin Board of Trade for I9II. 
or later cause the butter trade to be organized in the same way that the trades in other commodities capable of standardization have been organized. This fact played a greater rôle than the conflict between producers and wholesale dealers. It is through these organized markets that a system of grades can be established and prices for each grade can be socialized. This feature brings fairness into dealing because the producers and receivers are both informed as to prices. Whether the initiative in organizing the market is taken by the producers or the dealers, the result is largely the same, and the benefits accrue to both classes.

\section{THE CONTRACT SYSTEM}

After the organization of the boards of trade and exchanges for the sale of butter, the way was paved for the adoption of a different method of doing business between producers and wholesale dealers. Selling on commission gave way to the "contract system" by which the receiver contracted with the producer to receive his butter and pay for it at the exchange price. In some cases, depending upon the quality, risks involved, and the terms of credit, the price at which the butter is contracted, is above or below the exchange quotations. This plan became possible after the establishment of a true market price, and was forced upon the wholesale dealers as the prevailing method through competition among themselves to market the butter. It became customary for dealers not only to advertise to pay the market price on the day of arrival, but also to send their agents through the producing territory in order to enter into contracts with producers for a specified time. During the spring of the year many such contracts are entered into. ${ }^{1}$ While the prevailing method in most

${ }_{1}$ The Elgin Dairy Report, April 4, 1904. 
parts of the country is the "contract system", the very poor butter is still largely sold on commission, because for this kind of butter there is frequently no market price, and the only way that it can be disposed of is on the basis of a percentage of what it will bring.

\section{COLD STORAGE}

Cold storage has in recent years become an important part of the machinery of the butter market. Mechanical refrigeration came into use shortly before 1890 and from this time to 1893 the development of cold storage as a public utility in the preservation of food was very rapid. ${ }^{1}$

In the early days, and as late as 1879 , the preservation of summer-made butter for winter use was principally the producer's task. The dairyman packed it, preserved it with brine or salt, and stored it in cellars. At that time the summer-made butter was far superior to the winter-made butter, and in spite of the fact that it was held for a considerable length of time and preserved by crude methods, it was a " most rare acquisition to the winter stock of provisions in a city family". ${ }^{2}$ This kind of butter, however, could not stand the competition of good creamery butter made in the winter. The scientific methods that were beginning to be applied improved the quality of the wintermade butter, and after I 879 made it unprofitable to hold butter on the farm preserved in the old way. ${ }^{3}$ But with the introduction of mechanical refrigeration butter could be held for a long time in a very good condition, the deterioration being so slight that it would bring within a cent or two as much as butter fresh from the creamery.

${ }^{1}$ U. S. Department of Agriculture, Bureau of Statistics, Bulletin IOI, p. 8 .

${ }^{2}$ Ohio Agricultural Report for 1858 .

${ }^{3}$ Review of the butter trade in the Report of the N.Y. Chamber of Commerce for 1879, p. 56 . 
A public cold-storage warehouse represents an investment of a large amount of capital and can only be operated where a great deal of business is available. The successful operation of such an establishment also presupposes banking facilities, because the butter is usually stored in June and July and sold late in the winter or early spring. It becomes necessary therefore in order to conduct the ordinary business during the storage season to make loans secured by the butter in storage. It is for these reasons that all the large public cold-storage warehouses are located in the big distributing centers. Thus the preservation of summermade butter for winter use has not only been greatly improved but the risk that it involves has been largely taken over by the dealers, whereas in former years it was principally assumed by the producer. 


\section{CHAPTER VII}

The Present Organization of the Butter Market

\section{THE DISTRIBUTING CENTERS}

THE total production of butter in the United States in 1909 was over $1,600,000,000^{1}$ pounds which expressed in value is considerably over $\$ 400,000,000$. This commodity must therefore be regarded as an important article of commerce. Its importance can be better appreciated when it is compared with the value of the wheat crop in I909, which, according to the census, was $\$ 657,656,8$ or. Of the total amount of butter produced in 1909 , more than half was made on the farm. Most of the farm-made butter is consumed locally, and only the portion that is renovated is of importance in big markets. While renovated butter forms a large part of the butter consumed in cities, its production seems to be gradually decreasing. This is of course due to the fact that the manufacture of butter is gradually passing from the farm to the factory, leaving less and less poor butter to be renovated. Most of the butter produced in the factory, however, is sent to the city. In I909, the factory product was $624.764,653$ pounds. ${ }^{2}$ During that year $47,-$ 345,36r pounds $^{3}$ were renovated. Adding these two amounts we have a rough estimate of the quantity that was distributed during 1909 among the more populous centers of the United States.

1 According to United States Census.

2 From United States Census.

3 From the Report of the United States Internal Revenue Commission. 377] 
The butter belt of the United States is in the north central geographical division, the state of IVisconsin leading with a factory product of $103,884,684$ pounds. Of the eastern states New York and Pennsylvania still produce large amounts. Five of the north central states, Wisconsin, Iowa, Minnesota, Michigan and Illinois, produce more than half of the total factory product of the country, and therefore more than half of the butter that passes through the big distributing centers comes from this section. The most important cities that take part in distributing this product are Chicago, New York, Philadelphia, Boston, San Francisco, and St. Louis. Table no. 15 shows their relative importance.

\section{TABLE XV}

Receipts of Butter at the Principal Markets in the United States (OOO OMITTED)

\begin{tabular}{|c|c|c|c|c|c|}
\hline & 1895 & 1900 & 1905 & 1910 & 1913 \\
\hline & Pounds & Pounds & Pounds & Pounds & Pounds \\
\hline Chicago ............. & 185,453 & 244,385 & 271,915 & 318,986 & 277,651 \\
\hline New York ......... & 110,340 & 115,320 & 143,300 & 135,420 & 151,020 \\
\hline Philadelphia ....... & .......... & . . . . . . & 33,233 & $\cdots$ & ........... \\
\hline Boston ............. & 46,787 & 51,503 & 66,725 & $69,42 I$ & 70.737 \\
\hline San Francisco...... & $x, 344$ & 14,564 & $17,45^{\circ}$ & 13.922 & 23,122 \\
\hline St. Louis .......... & 15,812 & 12,901 & 15,566 & 23,163 & 24,726 \\
\hline Milwaukee ........ & 4,229 & 5,304 & 8,091 & 7,319 & 9,068 \\
\hline Cincinnati ......... & 12,200 & 22,300 & 15,500 & 13,500 & 10,300 \\
\hline
\end{tabular}

(From Agricultural Yearbook and Reports of Boards of Trade.)

Chicago is a great interior distributing center. In I9I4, it received 3II,557,000 lbs. of butter and shipped the same year to various points in the country $295,784,0001 \mathrm{bs} .{ }^{1}{ }^{1}$ leaving for local consumption $5,773.000$ llbs. This is of course

${ }^{1}$ Report of the Chicago Board of Trade for 19I4, pp. 102 and 103. 
far in excess of the amount passing through any other city. The reason for this is plain. Chicago is in close proximity to the producing area, and is connected by good transportation service with this section of the country as well with the big cities of the east and south. There is therefore no doubling of transportation costs in the disposition of the butter at this point. Next to Chicago, New York receives more butter than any city in the country. Its local demands of course are great. But there is also considerable out-of-town trade, and most of the butter exported from the United States is shipped from this port. It also receives most of the butter imported. Both exports and imports of butter are small compared with the total amount produced and consumed in the United States. The extent of the foreign trade as well as the places through which exports and imports pass may be seen from table no. $16{ }^{1}$

Boston and New York on the Atlantic Coast, San Francisco and Puget Sound on the Pacific Coast, points in Michigan on the northern boarder, New Orleans, Corpus Christi, and other towns in Texas and Arizona on the southern border, are the principal outlets for shipping butter to foreign countries. No butter comes into the country along the southern border. But considerable quantities cross the Canadian border into Vermont, New York and Michigan.

Prior to I9I4, the imports for some years past were only a little more than $1,000,000$ pounds, ${ }^{2}$ but during I9I4 there was a big increase. This was principally due to the reduction of the tariff from $6 \mathrm{c}$. a pound to $2 \frac{1}{2} \mathrm{c}$. The new rate went into effect October 4, I9I3. With the high duty of 6c. a pound on butter, only the best butter came into the

1 From Reports of the United States Burean of Foreign and Domestic Commerce.

2 Ibid. 
country. But as soon as the duty was lowered to $21 / 2 \mathrm{c}$. the poorer grades began to come in. Siberian and Australian

\section{TABLE XVI}

DOMESTIC IMPORTS AND EXPORTS OF BUTTER

\begin{tabular}{|c|c|c|c|c|c|}
\hline \multicolumn{6}{|c|}{ IMPORTS } \\
\hline & 1914 & & 1910 & & 1905 \\
\hline Massachusetts....... & $\begin{array}{l}\text { Pounds } \\
\text { I } 24,254\end{array}$ & & Pounds & & Pounds \\
\hline New York......... & $2,7 \mathrm{~S} 6,173$ & .................. & 671,897 & ......... & 42,182 \\
\hline Porto Rico ........ & 318,875 & ............... & 181,762 & ........ & $68,78 \mathrm{I}$ \\
\hline $\begin{array}{l}\text { Hawaii .............. } \\
\text { San Francisco..... }\end{array}$ & $\begin{array}{r}\text { I } 15,426 \\
\text { I,638,461 }\end{array}$ & …… & 25,175 & & \\
\hline Washington (State). & $1,134,75^{2}$ & Champlain, N. Y.. & 287,219 & $\ldots \ldots$ & 404,785 \\
\hline Chicago .............. & 859,693 & & & & \\
\hline $\begin{array}{l}\text { Dakota } \ldots . . \ldots \ldots \ldots \\
\text { Eastern Vermont.... }\end{array}$ & $\begin{array}{r}131,757 \\
51,687\end{array}$ & $\begin{array}{l}\text { Buffalo, Ck., N. Y. } \\
\ldots \ldots \ldots \ldots \ldots \ldots\end{array}$ & $\begin{array}{l}48,772 \\
58,675\end{array}$ & & \\
\hline Michigan............ & 72,788 & Niagara, N. Y.... & 35,007 & (...... & 10,990 \\
\hline 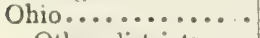 & 396,234 & & & & \\
\hline Other districts.... & 211,922 & $\cdots$ & $5^{1,73^{8}}$ & $\ldots \ldots$ & 66,366 \\
\hline Total .......... & $7,842,022$ & $\ldots$ & $1,360,245$ & & 593,104 \\
\hline & $\$ \mathbf{I}, 753,46 \mathbf{I}$ & & $\$ 298,023$ & & $\$ 124,136$ \\
\hline
\end{tabular}

EXPORTS

\begin{tabular}{|c|c|c|c|c|c|}
\hline & 1914 & & | 1910 & & 1905 \\
\hline & Pounds & & Pounds & & Pounds \\
\hline New York......... & $2,900,157$ & n.............. & $2,210,978$ & $\cdots$ & $7,699,693$ \\
\hline Boston. ........... & .......... & ................. & $\ldots . .$. & $\ldots \ldots$ & $\mathrm{I}, 027,260$ \\
\hline New Orleans....... & $373,3^{80}$ & n................ & 288,932 & $\ldots \ldots$ & 279,079 \\
\hline San Francisco....... & 104,935 & . $\cdots \cdots \cdots \cdots \cdots \cdots$ & 84.704 & ....... & 165,112 \\
\hline Washington (State) & 183,124 & n................ & 128,180 & (...... & 75,103 \\
\hline Paso del Norte, Tex. & $\ldots \ldots \ldots$ & |.............. & $201,3^{8} 3$ & $\ldots \ldots$ & I $23,38 \mathrm{I}$ \\
\hline Arizona ............. & …...... & $\cdots \cdots \cdots \cdots \cdots \cdots$ & $\cdots \cdots \cdots$ & $\cdots \cdots$ & $\times 65,843$ \\
\hline Other districts...... & I 32,001 & $\cdots \cdots \cdots$ & 220,300 & $\cdots \cdots \cdots$ & 536,016 \\
\hline $\begin{array}{l}\text { Total............ } \\
\text { Value.......... }\end{array}$ & $3,693,597$ & & $3,140,545$ & & $10,071,487$ \\
\hline Value.... & & & & & $\$ 1,64$ \\
\hline
\end{tabular}


cold-storage goods came into New York from London. But fresh goods from Siberia, Denmark and Argentine were also received. New Zealand shipped large quantities to the Pacific Coast. ${ }^{1}$ The new competition caused considerable readjustment in the movement of goods. Much of the butter that was formerly sent to the San Francisco market had to be diverted to eastern and other points.

The amount of butter exported from this country has decreased considerably since I 890 , when nearly $30,000, \infty 00$ pounds were exported. In I9I4, the amount exported was less than 4,000,000 pounds. This decline is due to several causes. With the appearance of oleomargarine and renovated butter, large quantities of this stock was sent abroad, marked as "Finest American creamery butter". 2 This deception soon destroyed our reputation for making good butter just as our reputation for making good cheese was lost by exporting adulterated and filled cheese. The Secretary of Agriculture took the position that all butter for export should be inspected and certified by the government as is done in the case of meat and meat products. Oleomargarine for export is inspected and the manufacture of renovated butter is supervised at the factory. But there is no certification of butter exported as to whether or not it is fine creamery or some poorer quality. The Dairy Division for some years has been making attempts to develop the export trade and establish our reputation in foreign markets, ${ }^{3}$ but judging from the amounts exported these efforts have been almost fruitless. In spite of the fact that Canada had the system of inspection that was asked for in this country

\footnotetext{
${ }^{1}$ Review of the butter trade in Report of the Chamber of Commerce for 1913, p. 79 .

2 Agricultural Yearbook for I899, p. 52.

3 Agricultural Yearbook for 1912, p. 155.
} 
its exports have also decreased from $34,000,000$ pounds in I 902 to $4,000,000$ pounds in I9IO. In I9II, the amount was a little more than twice that of the previous year. ${ }^{1}$ The principal reason for the decrease in the export trade is the increased production of butter in some of the other countries and the prevailing high prices in this country. Siberia is producing more butter, and, like Sweden, is shipping its products through Denmark ${ }^{2}$ in order that it may be exported from the country that enjoys the highest reputation for good butter. Australia has also been shipping to European ports. This increased supply has had the effect of lowering prices. But in this country, prior to October 4 , I913, there was a duty of $6 \mathrm{c}$. a pound on butter and at the same time there has been a growing demand. During recent years therefore high prices have prevailed in the United States which make it unprofitable to export. The butter that has been exported in recent years was usually of the poorer grades and ordinarily in the summer time when prices were at the lowest point.

The efficacy of the market organization in moving butter to points of high prices is illustrated by the events of 1905 :

Within two weeks the line of values on table goods had fallen IOc. The best fresh creamery sold at $25 \mathrm{c}$. On sober thought, however, it was seen that this break was wholly unwarranted. Stocks of old goods were fairly well cleared, and despite the fact that the entire country was scraped as with a fine-tooth comb for supplies, our market was soon bare of stock. About fifty car loads of the previous stmmer's make that were held in San Francisco were brought here as speedily as posșible,

\footnotetext{
${ }^{1}$ Figures taken from United States Agricultural Yearbook for 1907 and 1912.
}

${ }^{2}$ Agricultural Yearbook, 1903, p. 482. 
the railroads making a special rate of $2 \mathrm{c}$. per pound in refrigerator cars to the eastern seaboard. Dealers also brought about I0,000 packages across from Canada on which a duty of $6 \mathrm{c}$. per pound was paid. ${ }^{1}$

\section{THE DEALERS}

Dairy butter is frequently sold directly to the consumer. The farmer delivers it with his own team to the customer's door, or brings it to the city's public market where it is taken from the farmer's stand. Some is sold to the rural merchant who constitutes the middleman between the producer and the village folk. Some is also sold to hucksters who travel on regular days through the country and collect butter, eggs, poultry, vegetables and other produce. The huckster sells it to the wholesale dealer.

Some of the creamery butter is also sold to the rural merchant, but most of it is shipped from the factory to the wholesale dealer of the city, by him sold to the jobber who sells it to the retailer or grocer, and by the grocer sold to the consumer. Most of the factory butter therefore passes through three middlemen. But there are exceptions to this method. In at least one case the butter is sold directly to the consumer. The creamery ships to delivery agents where there are enough customers to warrant their employment, and where the customers are fewer the butter is delivered by the express company. ${ }^{2}$ In this case there is no middleman except a delivery man whose services, however, in addition to providing local transportation, include those of a salesman. Because of the fact that in every large city there are a number of " chain " grocery stores, a considerable por-

\footnotetext{
1. Review of the butter trade in Report of N.Y. Chamber of Commerce for 190.5, P. 50.

${ }^{2}$ U. S. Department of Labor, Bureau of Labor Statistics, Bulletin 164, p. 32 .
} 
tion of the factory butter passes through only one middleman. Some of these have a special contract with a wholesale dealer in butter to do the buying for them; but others have a department in their own organization that does the buying for the various stores according to their needs as to quality and amounts. The Great Atlantic \& Pacific Tea Co. is probably the largest concern of this kind. In March, I9I 5, this company was operating one thousand stores. It has several butter and cheese departments located in different cities. Some of the large producers sell direct to the consumers through their own stores. An example of this type of selling is the Slawson-Decker Co., operating in New York. This concern deals in milk primarily but also makes large quantities of butter which is sold at their milk stores. Some of the large producers in the middle west, known as "centralizers", sell directly to the retail trade through their own jobbers or salesmen. ${ }^{1}$ The usual method for the cooperative creameries is to ship to a city wholesale dealer. But if the principle of coöperation at present applied to production be extended to marketing, there is no reason why they should not establish a selling agency of their own. Only recently the coöperative creameries of Jackson County, Wisconsin, organized with a view primarily to improve conditions in making butter, but their hope is also to facilitate the marketing of the product. ${ }^{2}$ With such an organization of a number of creameries the coöperative factories can afford to establish selling agencies of their own. Obviously the product of one factory is not sufficient to meet the expenses of a selling agency, but when the product of a number of factories can be collected and shipped in car-

1 U. S. Department of Labor, Bureau of Labor Statistics, Bulletin I64, pp. 35 and 39.

${ }^{2}$ N. Y. Produce Review and American Creamery, Jan. 6, I9I5, p. 564. 
load lots, a saving in transportation service can be made, and the expenses of selling can be met because of the large quantities distributed. It will be noted that where the method of direct selling is approached there is concentration or combination either in production or in the market. Both the "centralizers" and "chain" stores in many cases have reduced the number of middlemen.

The essential function of the retailer of butter, who usually sells other produce, is to get customers and retain them. In his store there is considerable manual labor that he must do. The fact that he deals in a variety of produce makes it impossible to become an expert judge of market conditions in all of them. For these reasons the individual retailer can not run after the goods but must rather have them brought to him. In the performance of his duties he becomes the basis to judge demand. He tries to sell all the butter he can, but in so doing he is in competition with other retailers. It becomes necessary therefore to sell at the lowest price possible. Perhaps he must sell below cost; and if so he will be slow to order more at the same price. This feeling is made known to the jobber. There is therefore a focusing of the conditions of demand in a group of dealers much smaller in number than the retailers.

The jobber has his own special duty to perform. It is his particular business to induce the retailer to take goods of the quality for which there is an effective demand in the community. The rich classes can pay for the best while the poor people must be contented with the cheaper qualities. He must furnish to the baker packing stock or creamery butter according to his requirements. In connection with this work of distributing butter according to local needs there is considerable labor necessary, both manual and clerical. The most important qualification required of this dealer is that of a salesman. He must be able to "get busi- 
ness". The jobber is in competition with others of his class and with "chain" stores that receive butter directly from the producer. He therefore makes the most attractive offers possible. Whether or not the goods are easily disposed of at the prices asked is a fact that is quickly communicated to the wholesale dealer, and thus the demand situation becomes a matter of common knowledge to the comparatively small group of dealers.

The group of wholesale dealers also renders important services in the butter trade. They take the initiative in causing the butter to move from the point of production to the city. Trips are made to the factory and contracts are entered into. Frequently instead of visiting each factory, representatives are sent to places where conventions of state dairy assuciations are held, with a view to meeting a large number of butter men. A great deal of advertising is done by the wholesaler in dairy journals and much of the business is acquired in this way. The wholesale dealer must be prepared to invest considerable capital in his business. It is necessary to have efficient refrigeration service of his own in order to hold lots for short periods until they are sold. He must be able to secure credit at a bank. In a great many cases the shipper stipulates in making a contract with the wholesale clealer that a portion of the goods shall be paid for f. o. b. factory or upon day of arrival at print of clestination. This is done by cirawing on the wholesaler for perhaps sixty or seventy-five per cent of the value of the shipment. The bill of lading is attached to the draft which is forwarded to the wholesale dealer's bank. Of course in some cases the wholesale riealer sells on time. But in such cases the producer is often paid better prices in the form of premiums; or it may be due to the fact that the wholesale dealer enjoys a very high reputation for skillful and fair dealing. The wholesale dealer also assumes con- 
siderable risk and responsibility. He receives large lots of butter and pays mostly for the goods outright. For this reason the wholesale dealers must watch the butter market of the world. It is therefore in the minds of this group of dealers that the market price develops into a definite figure, and from them a skillful reporter of prices may determine an average of their estimates as to what the market prices should be.

\section{THE ORGANIZED MARKETS}

One of the most important functions that the organized market serves is the collection of data concerning supplies and the condition of the market. A good deal of this work in recent years has been taken up by publishers of daily or weekly reports giving all facts available. Such reporters get much of their information from the sales under the "call" of the organized market, but in addition they interview its members individually as well as other dealers and exporters, and ascertain the receipts of butter into a city and the amount of stock on hand. Similar market data for other cities are also secured. Facts are gathered from the field of production. All this information is published daily and distributed among the dealers. An example of this kind of pulblication is the Producers ${ }^{\prime}$ Price Current ${ }^{1}$ issued daily at about four p. m. Members of organized markets, as well at other dealers, and producers place considerable reliance upon information appearing in such publications. But in addition to this source of information the organized market has its own publicity service. Bulletins of receipts and prices of butter are exhibited in the exchange rooms. Upon a large glass weather map the daily weather conditions of the entire country are charted for the New York

${ }^{1}$ Published by the Urner-Barry Co. of New York City. 
Mercantile Exchange by an employee of the United States Weather Bureau. Other publications, such as weekly forecasts and snow and ice bulletins during the winter, are also posted. A ticker and other telegraph service is maintained. The weekly receipts of butter are watched very closely because this amount will determine the stocks on hand from time to time and has a direct bearing on the price. The average amount distributed weekly in the city and to outof-town customers, is a matter also kept in mind, because this amount determines the normal effective demand of the city. When therefore the receipts very appreciably rise above or fall below the normal consumptive requirements, a change in the price may be expected. Attention to the weather is by 110 means as close in the butter market as it is in the cotton market, obviously for the reason that the production of butter is not dependent upon the weather to the same degree as the growing of cotton. Usually only abnormal conditions are watched, such as an early spring, prolonged hot and dry spells, unusually long and cold rain storms, ctc. All of these conditions have a very direct influence upon the country's output, and therefore a bearing upon the price. Anything that will interrupt transportation and prevent the receipts from coming into the city, even though it be only for a few days, is a matter carefully watched. Disturbances of this nature are floods, blizzards and railroad strikes. This factor becomes especially important when shipments are delayed at a time when stocks on hand are low. Thus during the second week in January, I9I2, the country became almost snow-bound, causing a rise of $4 \mathrm{c}$. per pound on the better grades. ${ }^{1}$ During the last week in March, I9r 3 , floods in Ohio, Indiana,

1 Review of the butter trade by Urner-Barry Co. in the Report of the N. Y. Chamber of Commerce for 1912, p. 73. 
and Illinois seriously interrupted traffic on several of the trunk lines, and caused the receipts into New York City to be extremely short. This had the effect of raising the price of fresh creamery for one day to $42 \mathrm{c}^{1}{ }^{1}$ Matters affecting demand are also closely watched. The vacation period during which people of the city go to the country and other resorts is kept in mind. If the summer keeps cool it is expected that a great many visitors will come to the city, and that fewer will leave for vacation resorts. Also such general matters as prosperity and depression are taken into account, because these factors very materially influence the price of butter as may be seen in the next chapter.

With all the information concerning conditions of supply and demand published and absorbed by members of the organized market, each one has his own estimate of what the price should be. Trading can therefore begin on an intelligent basis. Individual estimates, all based very largely on the same data, are modified as trading proceeds, and at the end of the day's business they show a tendency toward uniformity. The method of sale on the floor of the exchange, as already explained in the previous chapter, is by the "call", which is a kind of auction. No samples of butter are displayed, but all selling is done by grade. In addition to these regular sales there are a very large number of sales effected privately between members on the floor. One aspect of the organized market therefore is that, like any other market, it brings buyers and sellers together to a common meeting place. In addition, however, to "spot" buying and selling, provision is made for the sale or purchase of butter "to arrive" or for "future delivery ". When the sale of butter for "future delivery" is

1 Review of the butter trade, op. cit., for 1913, p. 78. 
made in the New York Mercantile Exchange, the following form ${ }^{1}$ of contract is filled out and signed by both the seller and buyer:

No.

This is to certify that the following sale and purchase has been made by the respective signers hereto, under and subject to the rules of the New York Mercantile Exchange, this

day of $191 \ldots$.

Seller

Address

Purchaser

Address

Quantity

Grade

Class

Price

Delivery

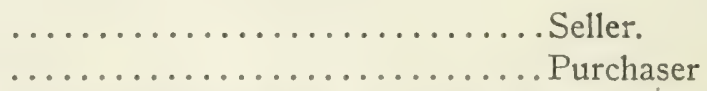

Original margins deposited with me this day by each party hereto ............... dollars.

Superintendent.

New York, . I9I, ....

According to no. 2 of the Executive Committee's rules, each party to the contract is required to deposit with the Superintendent of the Exchange a margin equal to Io per cent of the contract price at the time of the sale and a further margin from time to time to cover variations in the market price. The margins are deposited in a bank designated by the Finance Committee of the Exchange. Con-

${ }^{1}$ Butter Rules of the New York Mercantile Exchange, Oct. I, IgI4. 
tracts for future delivery may be transferred to other members; when this is done the following form is used:

For Value received, the within described contract is assigned

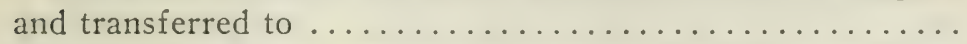
who hereby agrees to assume the same, with all the conditions and obligations thereof.

Dated, New York, ...................

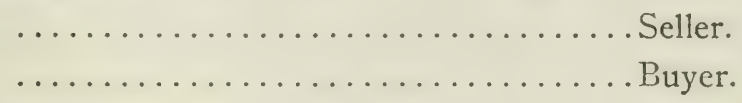

These sales do not form an important part of the business in organized markets.

In connection with buying and selling under the "call" there is opportunity on the part of members to make "wash" sales for the purpose of affecting the market price. For instance, butter rule no. 9 of the Boston Chamber of Commerce, after prescribing penalties for non-fulfillment of contracts, follows with this statement: "But nothing in this rule shall be construed to prevent a different settlement by mutual consent". ${ }^{2}$ The New York Mercantile Exchange rules also make provision for the cancellation of similar contracts that two members may hold against each other. It is denied in trading circles that "wash" sales are made. Obviously if they are made, their occurrence is not a matter of common knowledge, not even to the officials of the exchange. But that they are sometimes resorted to seems to be indicated by the fact that the Elgin Board of Trade has been enjoined "from making fictitious or washed or pretended sales or purchases of butter for the purpose of misleading any person or persons as to the actual price at which butter is being sold upon said Elgin Board of Trade, or

Report of the Boston Chamber of Commerce for 1913, p. 210. 
which are intended to be used in any way as a basis for the making of quotations of prices on said Elgin Board of Trade ". ${ }^{1}$

A very important function that the organized market serves is the regulation of the trade. By parliamentary methods it can establish grades and compel their adoption in trading under the "call " and in connection with the quotation of prices. This feature, as was seen in the previous chapter, is fundamental in establishing a market price for the various qualities of butter. The exchange rules in many cases are in the nature of a code of ethics that are made binding upon all the members of the exchange. Of this nature are the rules on inspection. When butter is sold either party may ask for an official inspection. This happens when the purchaser contends that the lot tendered is not of the grade sold him; or it may happen when there is doubt by both parties as to the grade, and the owner of the butter being anxious to effect a sale may ask for an official inspection. According to the rules of the New York Mercantile Exchange, the party ordering the inspection pays for it. But in many cases, presumably by mutual agreement, the party whose contention as to the quality of the butter fails to be supported by the result of the inspection pays the fee. The amount of the inspection fee ranges from $\$ 0.75$ for 25 tubs to $\$ 2.50$ for 500 tubs. The fees are paid into the treasury and form, next to dues of members, the most important source of revenue of the organized market. Immediately after the inspection a certificate is filled out and given to the party ordering the inspection. For this purpose the following form is used:

${ }^{1}$ Decree entered April 27, 19I4, in the District Court of the United States for the Northern District of Illinois, Eastern Division. 
ELGIN BOARD OF TRADE

BUTTER INSPECTOR'S DEPARTMENT

Elgin, Ill................. $191 \ldots$

I hereby certify that I have inspected the following lot of butter for.....

with the following result:

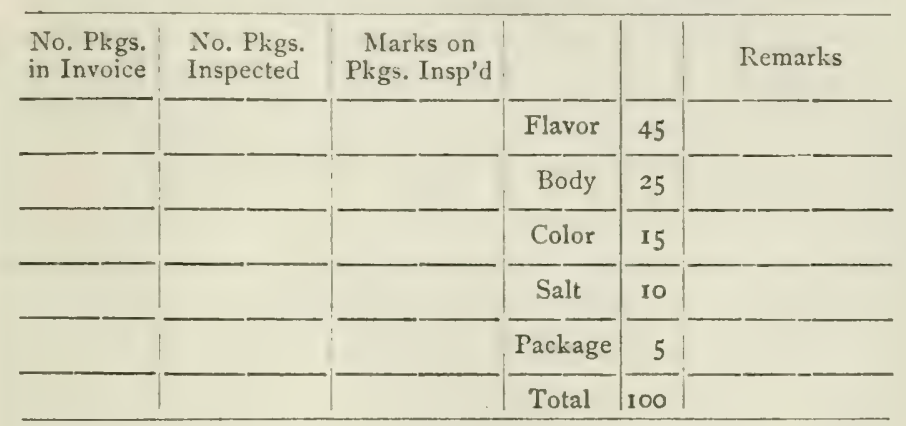

Fees...............

Inspector

The New York Mercantile Exchange rules require this certificate to be countersigned by the Superintendent. While inspection is mostly resorted to in cases of dispute or doubt, some buyers, like the United States Navy Department, for instance, frequently require goods to be tendered "certificate attached". Inspections are very frequently made. During the month of February, I9I5, the Inspector of the New York Mercantile Exchange made $361^{1}$ official inspections; in this month there were only 22 working days. Inasmuch as the rules require, in case the lot of butter tendered fails to pass inspection, that another tender be made, and for the reason that ultimately the purchaser is guaranteed a satisfactory delivery and the seller is assured of the disposition of his butter when properly tendered, trading is done on a perfectly safe and legitimate basis.

${ }_{1}^{1}$ New York Produce Review and American Creamery, March 3, 1915. 
In matters pertaining to transportation facilities, where concerted action is necessary, the exchange also plays an important part. On holidays the railroads endeavor to secure the sentiment of the exchange as to whether or not dealers desire to deliver goods. Recently, at the suggestion of the Interstate Commerce Commission that the railroads develop new sources of revenue, one of them being charges for terminal services, the trade was notified that butter and eggs had to be removed from the docks within 48 hours after the arrival of the shipment instead of 72 hours as theretofore. The changes proposed by the railroads would affect the New York Produce Exchange, whose members are principally dealers in grain and flour; and the matter was by them taken up with the Interstate Commerce Commission. The New York Mercantile Exchange also appointed a committee to attend the hearings of the Commission and protest against the proposed changes. ${ }^{1}$

Other regulations emanating from the organized market are in the nature of protection for its members whose interests are common and opposed to the interests of another class with whom they must deal. An example of this kind of regulation is fixing the rate of commission by the members of the Los Angeles Produce Exchange in I903. The establishment of the quotation committee for the purpose of determining prices is of the same nature. While the opposition between the trading class and the producing class may at times be a conscious effort to control prices in favor of the group making them, it is perhaps more frequently the result of a biased feeling or the prevailing sentiment of the class as to what is a correct price.

In I896, the Elgin Board of Trade created a quotation committe of five members charged with the duty of making

${ }^{1}$ New York Produce Review and American Creamery, March 3, I9I5. 
the official price quotations of the Board. ${ }^{1}$ Upon the completion of their task these quotations were immediately wired to all butter markets of the country. It is claimed that this course was necessary because the "contract system" of trading had become common and decreased the amount of trading under the "call" of the Board to such an extent that these sales no longer reflected the true market price of butter. Too wide variations in prices at the sales under the "call" made it desirable to charge a committee with the task of harmonizing these, with the injunction that they were expected to take into account factors of supply and demand. In 1903, similar quotation committees charged with the duty of establishing prices for butter. eggs, and cheese were organized by the New York Nercantile Exchange. The Chicago Butter and Egg Board and the Boston Chamber of Commerce followed the same plan. In the New York Mercantile Exchange these committees quoted official prices until 1907, when the Supreme Court restrained them. After this the committees were reorganized to comply with the order of the court that no quotations be made except those based on actual sales. But owing to a quarrel among members representing different interests on the Exchange the quotation of prices by committees was discontinued, and "the work was taken up by trained reporters, and from that time to the close of the year these men reflected in their daily quotations, [as they have probably ever since], more nearly the actual wholesale selling prices than had been given for some years previously". 2 The Elgin Board of Trade, in accordance with a decree entered by the United States Government in the District Court of Northern Illinois, Eastern Division, was enjoined April 27, I9I4, not only from quoting prices except those

${ }^{1}$ The Annual Report of the Elgin Board of Trade for 1911.

${ }^{2}$ Report of New York Chamber of Conmerce for 1907, p. 49. 
"which have actually obtained on said Board in bona fide sales of butter", but also from making "wash" sales and sales for "future delivery" in which both parties do not in good faith intend to make the transfer of the actual commodity. If this restraining order is complied with, there can be no way of establishing a price that is representative of conditions except by a large number of sales under the "call" of the Board. The officials of the Elgin Board are desirous of making this possible, and are conducting a campaign to induce a larger number of patrons to offer their butter at the Board's auction and thus participate in establishing a real competitive price instead of selling on the "contract system" by which prices do not become known.

The interests of the producing class are of course diametrically opposed to the interests of the receiving class with respect to the quotation of prices. The former desire as high a price as possible under prevailing conditions, while the latter desire the quotations to be low in order that there may be a wider margin between the prices they pay to the producers and those they receive from the buyers. The wholesale dealers are in competition among themselves to secure all the butter possible, and in recent years have been paying in many cases from a cent to a cent and a half or more above the market quotations. If the butter contracted for is of very exceptional quality the dealer can well afford to make such an offer because he gets a better price for it. But if this is not the case he is liable to sustain losses when the quotations are high at a time when the city is fairly well stocked with supplies, because under such conditions he has great difficulty in selling the butter at good prices. The jobbers and retailers at times when supplies are plentiful naturally also recede to a safer position in order that they may dispose of the butter at a profit. The Elgin Board 
of Trade is a producers' exchange and its body of members as a whole are interested in maintaining high prices at all times. This was the principal object for which the Board was organized and has been its aim for many years. But since the introduction of the hand separator and the growth of the "centralizers" the situation has changed considerably. These large producers are interested in maintaining low prices for the reason that the butter fat which they buy from the farmers fluctuates with the price of butter, and is contracted by them to be paid for on the basis of the Elgin butter quotations. In addition to this fact it is charged by the Federal Government, in the investigation that led to the issue of the decree already referred to, that the "centralizers" are also large buyers of butter produced by small creameries throughout the middle west. This is bought in the summer when prices are low and held in cold storage to be sold in the winter. They are therefore interested, it is charged, in maintaining low prices during the summer and high prices during the winter when many of the small creameries are shut down and production generally has fallen off. Whether or not this latter inference is correct, it is plain that the interests of these large producers who buy the butter fat on the basis of the Elgin butter quotations and dispose of it very largely at a cent or a cent and a half above the quotations of some eastern market, are opposed to the interests of the farmers selling the cream as well as to the interests of the coopperative creameries whose total profits go to the farmers and are dependent upon high prices for butter. These large producers have command of large amounts of capital and are therefore in a position to do a great deal of speculative buying in the summer. To the extent that this is done they are of course in conflict with the interests of the small creamery that must sell as a rule as the butter is produced. Thus it is seen that 
the interests of the producers on the whole are in conflict with the dealers, and that the interests of certain groups of the producing class are also in conflict.

It is very difficult to determine just how far a quotation committee can fix prices above or below free competitive values. If it were possible to secure sufficient information concerning premiums paid by dealers, this might form a basis by showing how much too low the quotations of a middlemen's market are, or whether they are correct. As previously stated, premiums of a cent or more above the quotations are not alone paid for the reason that the dealer is anxious to get all the business he can, but for the reason that some butter has exceptional quality and will enable him to sell it at a high price and make a profit. Other considerations also enter in, stuch as risk and credit. Both of these items are expenses that can be paid for in the form of premiums. Paying for quality, risk, and credit, therefore, is the usual business practice in every trade and must not be confused with premiums paid by dealers without any regard to legitimate returns. Premiums of the latter type are paid because of the keen competition among dealers to secure the business of producers. According to the Elgin Dairy Report of September I4, I903, premiums of from $I 3 / 8$ cents to $I / 2$ cents were very generally paid at that time. Since that time they seem to have risen as high as three cents above the market price. ${ }^{1}$ The Elgin Dairy Report makes the statement that a "man who pays a premium, even if he is a member of the quotation committee, pays that premium secretly, and is not going to make it public for the benefit of the quotation committee". As the greater part of the trading is at private sale based on

1According to a complaint made in the Elgin Dairy Report and copied by the New York Produce Review and American Creamery, Aug. 12, I9I4. 
quotations the pressure of the dealers is all one way and that is downward. This may be an unconscions effort on their part, or it may be deliberate action. Obviously, however, the quotations can not be depressed very much too low because the butter would not come to the city where abnormally low prices prevailed. This, however, could be avoided by establishing quotation committees in every distributing center and having agreements entered into by all of the committees on the question of prices.

Correct quotations are so extremely important to the trade and producers, because of the time saved to every person concerned in determining the price, that some method should be found by which they may be in true accord with the conditions of supply and demand, and not made to favor only one group of interested persons. V'arious methods have been tried in Europe. In Hamburg, Germany, the Association of Importers and Exporters was organized about $1888^{1}$ with a view to quoting the real prices paid the producers. The plan was promised the support of the Schlestvig-Holstein Creamery Association providing the dealers would in no case pay a higher price than that quoted by the merchants' association. The plan was not successful, for about ISoo the Creamery Association began selling part of its output "by auctions, and has since then maintained them in ever-increasing degree in spite of the natural opposition from the merchants, whose committee evidently consists of dealers only". In Hamburg, a committee of fourteen members consisting of eight wholesale dealers and six retailers quotes prices. But the producers were also dissatisfied, and "in 1907 the Creamery Association of Mecklenburg-Schwerin started a butter auc-

${ }^{1}$ All data on European markets are based on an article by J. H. Monrad in the New York Produce Review and American Creamery, March 3, I9I5. 
tion in Berlin and this greatly helped to steady the quotations as it did in Hamburg.". In some places in Germany the municipal authorities have been represented on quotation committees. In Denmark, from I894 to I904, the quotation committee consisted of nine butter merchants and two agricultural representatives. In 1904, the producers withdrew because the quotations were too low and the dealers paid premiums. In November of the same year a remedy was sought in including the premiums. The quotations rose suddenly and this caused many complaints from England, but it was only a short time before premiums were again paid. In 1906, an agreement was reached between the producers and dealers by which the committee quoting prices was to consist of four representatives of the farmers and four merchants. In 1912, the farmers demanded that the chairman of the committee should be one of the merchants but should have no vote, thus giving the producers a majority. This caused a rupture and the producers started their quotations. Since then producers' and merchants' quotations have both been made and the two have probably a very healthful effect in arriving at a fair quotation.

Obviously the best way to establish quotations is to sell at an open auction providing that enough butter of all the grades is offered. This was formerly possible under the "call" in the exchanges but since the "contract system" has grown so extensively, the butter offered under the "call" is hardly sufficient to establish a representative price.

The task of quoting butter prices in this country now frequently falls to the lot of expert reporters who make it their business to gather all facts possible that may affect the butter market. The prices of sales under the "call" are taken into account as well as all prices made at private sales that can be secured. The reporter must be shrewd and skillful enough not to be unduly influenced by pessimistic 
views of dealers who have entered into contracts with producers to pay for their butter at high premiums. If the market reporters perform their duties properly " they give no consideration whatever to opinions of policy-to any judgment as to what quotations should be in order to accomplish sume supposed result in the future. They endeavor simply to dig out the fact of current values as governed by immediate conditions of supply and demand, and they give expression to these facts regardless of any opinion that they or others may have as to the effect upon future conditions. They believe that such an expression of actual trading values is the only logical regulation of normal market conditions, and the only judgment they use at all is in the interpretation of the evidence to determine the actual fact of current value. The quotations printed by them and furnished to other publications are not official in any sense; they are not arbitrary judgments as to what ought to be; they are to the best of their judgment and belief expressions of what is the current actual value as determined by passing conditions of supply and demand. The reporters do not stand at the throttle-they are simply acting as the steam gauge". 1

\section{COLD STORAGE}

Since I 890 cold-storage warehouses have become an impertant part of the machinery of the butter market. Cold st rage is to the butter trade what the grain elevator is to the grain trade. Like wheat, butter in large quantities is stured in the summer during the season of plenty for consumption during the winter when production has decreased. The movement of butter into and out of cold storage is shown by the following diagram: ${ }^{2}$

${ }^{1}$ New York Produce Review and American Creamery, March 3, 1915.

2 From United States Department of Agriculture, Bureau of Statistics, Bulletin 93. 
Diagram I.-Percentage of Year's Receipts or Deliveries

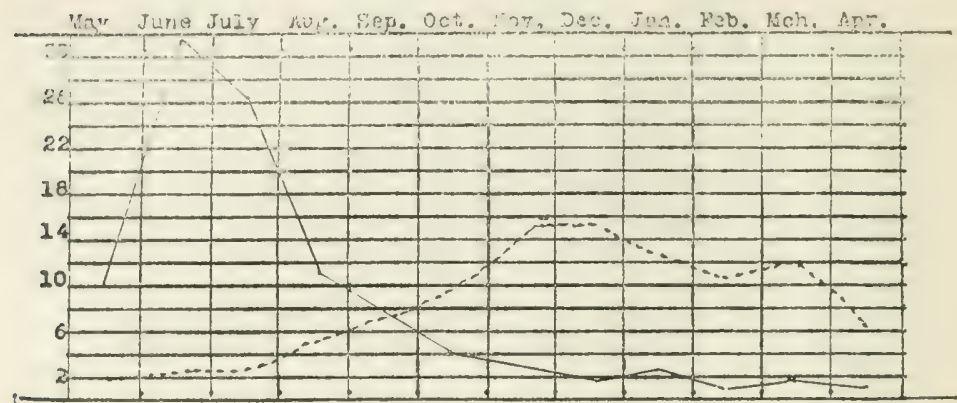

Receipts.

Deliveries.

(Receipts, I9I0-II; deliveries from receipts of I909-Io and I9IO-II.)

The physical properties of butter are of course very different from those of wheat, and this fact necessitates different methods of storing from those in use in storing grain. Owing to great uniformity of quality in grain, for the reason that it flows easily to lower levels, and because it is less perishable than commodities like butter, it is graded on the track and usually mixed with other grain of similar grades when stored. The method of storing butter must be different. The holder of butter rents space in the coldstorage warehouse. Into this space he places his butter, and when delivery is made the particular lot moves out. It is therefore not necessary to have butter inspected on the car before it is placed in the warehouse. The owner of the butter is given a warehouse receipt for the particular lot of butter stored. This receipt is a negotiable instrument. It is often transferred to other persons, and it is very frequently used to secure loans made at banks. In addition to public cold-storage warehouses, there are a great many dealers and producers who have storage facilities in their own warehouses or plants.

The movement of butter into cold storage is due to the 
action of speculators. The majority of the speculators are wholesale dealers, but a great many are jobbers; and even retailers store frequently. Retailers usually instruct their jobbers to buy and place the butter in storage on their account. Producers also store considerable quantities either at the creamery or in public warehouses. In the latter case the butter is shipped to a wholesale dealer of the city who is instructed to hold it on "producer's account". The individual motive of those taking part in this great movement may be said to be a selfish one, but the total result of the action of these speculators is a great economic service. If all the butter produced in the United States were passed directly from the factory into consumptive channels throughout the entire year much of it would be wasted, and the low prices prevailing generally through the summer would probably very seriously check the growth of the dairy industry. Thus the preservation of butter through cold storage benefits both consumers and producers. Its effect upon prices will be discussed in the next chapter.

In order that the trade may estimate what bearing the amounts in storage may have upon prices it is necessary that warehouse statistics be complied at regular intervals. Such figures are made up regularly but they do not include the stocks held all over the country. They are probably sufficient to show the trend of the movement into and out of storage, and thus give a fair idea of the total amount. In a letter received May II, I9I5, Mr. F. G. Urner, VicePresident of the Urner-Barry Co., Publishers, New York, has this to say concerning the way these figures are secured and the number of warehouses from which reports are available:

Storage figures for butter and eggs for the entire country are not compiled and are not obtainable. There are several 
hundred storage houses throughout the country. In the American Warehousemen's Association the cold storage section comprises, I believe, about 48 including many of the larger houses and some of the smaller ones. Of these 48 , nearly all - usually 45 or 46 -report their holdings to the Secretary monthly and the aggregate is by him disseminated.

For New York I have personally worked for a good many years to secure monthly reports and after meeting at first with opposition and more or less denial have of late years succeeded in obtaining reports from all but one small house where very little is stored. Boston houses have of late years reported their holdings monthly to the Exchange there, but one of these has now dropped out and declines to report. Philadelphia houses report to individuals and the figures become known through them. A few Chicago houses report in the same way, while others do not, and the holdings there are given in my compilations as partly estimated, the estimates being made by Chicago men who keep track of the relative inward and outward movement.

My impression is that the warehouses reporting to the American Warehousemen's Association carry approximately 40 per cent of the eggs and rather more than that of the butter, stored in the United States; but this is a guess. 


\section{CHAPTER VIII}

\section{Butter Prices}

INFLUENCE OF A PRODUCERS' EXCHANGE UPON PRICES

IN the chapter dealing with the history and development of the organized butter markets reasons for the organization of the producers' exchange were given. It was then said that the motives actuating the founders of the Elgin Board of Trade were to secure for the producers of butter higher prices and more satisfactory terms of sale than they were getting. It was also pointed out in the preceding chapter that the interests of the producers' markets and middlemen's markets are opposed to one another with respect to prices. Reference was also made to the federal investigation into the methods of quoting prices on the Elgin Board of Trade and to the decree enjoining the Board from quoting any prices other than those based on actual bona-fide sales. It was charged that the quotation committee was dominated by the centralizing interests, and that these big concerns bought large quantities of butter during the summer to be placed in cold storage and sold in the winter. The quotation committee, it was therefore said, was interested in maintaining low prices during the early summer and high prices in the winter.

An attempt is now made to show by actual figures whether these claims are borne out when the Elgin prices are compared with the New York prices. The former are producers' prices; the latter, middlemen's prices. It must be 405] 
remembered that the Elgin prices must necessarily be lower than New York prices, because on the Elgin Board the butter is sold f. o. b. shipping point. If the producers of the Elgin District paid the transportation cost the Elgin prices would naturally have to be higher, and in order that the element of transportation may be present in both prices, $\$ 0.0065$ has been added to the Elgin prices, in the comparisons that follow. From I893 to I9I 3 the freight rate "on butter, any quantity", from Chicago to New York over the Pennsylvania railroad "was $65 \mathrm{c}$. per $100 \mathrm{lbs}$ ". ${ }^{1}$ Of course not all the Elgin butter comes east. A great deal of it goes south. Nuch of the New York butter, however, comes from the North Central states, and it is believed that the New York and Elgin prices are placed more nearly on the same level by adding to the Elgin prices the freight rate from Chicago to New York.

Diagram no. 2 has been constructed to show the influence of the producers' market upon prices. In this diagram the variations of the annual Elgin prices from the annual New York prices are charted from I 890 to I9I3. From I 80 I to 1895 the Elgin prices were below the New York prices: but from 1896 to I9 I they were above the New York prices. The last two years they were considerably below the New York prices. The Elgin quotation committee was created in 1896 and quoted prices from this time to I9II. In I9I2 the government suit was instituted and the quoting of prices by a quotation committee was discontinued. It is seen that the contention of the officers of the Elgin Board, that producers selling on the basis of Elgin quntations were getting better prices than by selling on the quotations of other markets was not realized from ISgI to I 895 nor during the years I9I2 and I9I3: but that dur-

1 According to letter from G. H. Cobb, Division Freight Agent, Pa. R. R. Co., N. Y. C., dated May I4, I9I5. 
ing the time that the quotation committee quoted prices the Board attained the object for which it was organized. The diagram seems to indicate that after 1903 a new influence caused the difference between the two prices to be greater than at any time since 1896 . When it is remembered that in rgo3 the New York Mercantile Exchange created its quo-

Diagram II.-Variations of Annual Elgin Butter Prices from New

York Prices. Before Taking Differences $\$ 0.0065$ was Added

to Elgin Prices to Allow for Cost of Transportation

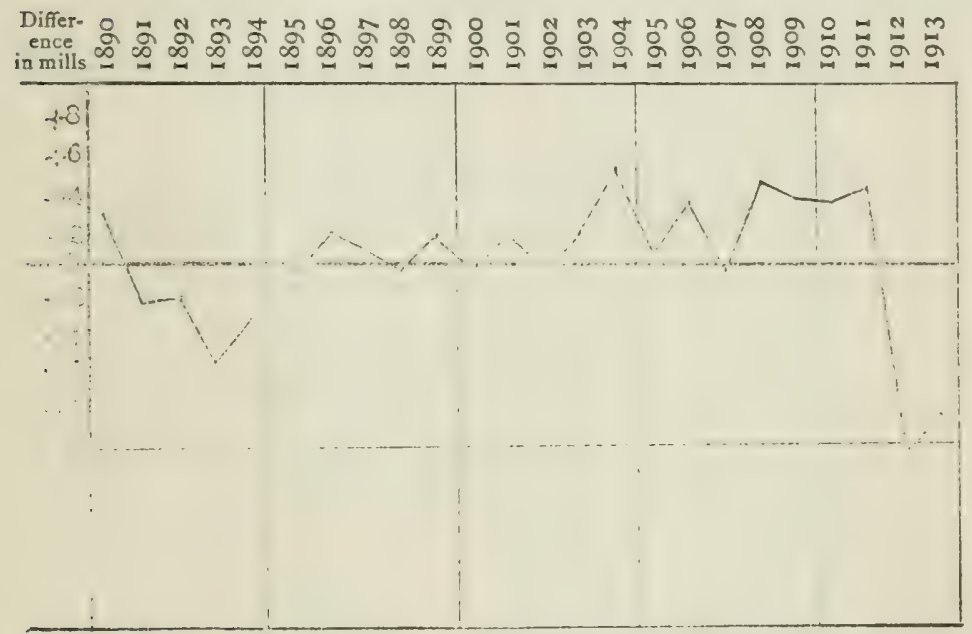

Data on which diagram is based from U. S. Bureau of Labor Statistics, Bulletin I49.

tation committee and that the middlemen desire low prices while the producers want high prices, the hint made in the previous chapter that these quotation committees actually did adjust prices favorably to their constituents seems to be verified by the results charted in the above diagram.

In order that the charge of the government that the Elgin quotation committee was dominated by centralizers who were buyers rather than sellers of butter in the summer, and 
sellers rather than buyers in the winter, may be examined in the light of figures, table no. I7 has been computed. In this table the differences between the monthly New York and Elgin prices are shown-that is, the New York prices are subtracted from the Elgin prices to which $\$ 0.0065$ was added to allow for the cost of transportation. The monthly differences are averaged for the period from 1893 to 1898 , because the rise of the large centralizers dates from

Diagram III.-Variations of Elgin Butter Prices from New Ycrk Prices dURing the Periods I893-1898 aNd I903-IgII

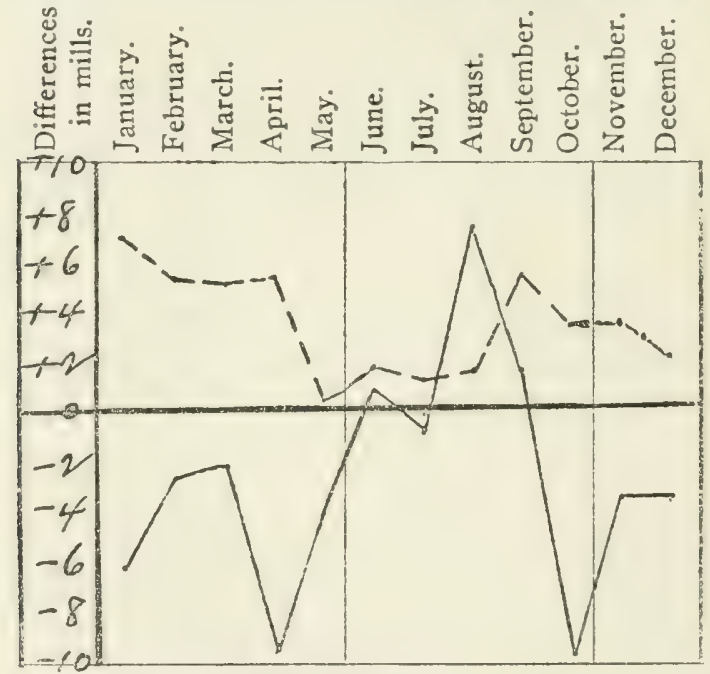

Average of monthly differences from 1893 to 1898 .

-.. Average of monthly differences from 1903 to I9II.

Drawn according to data in Table no. XVII.

this year. It is desirable to compare this period with the period when the centralizers, it is charged, entered the field of speculation and controlled prices on the Elgin Board to suit their convenience. In 1912 and 1913 there is a marked change in the prices which is probably due to the fact that 


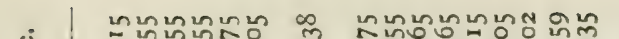

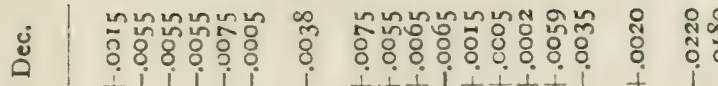

20 $+11111$ $++t+1+t+$ ii

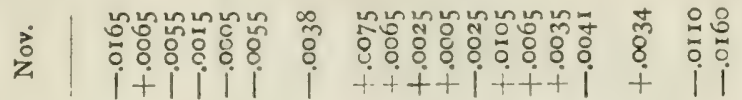
1

\begin{tabular}{|c|c|c|c|c|c|}
\hline 亗 & 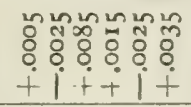 & $\begin{array}{l}20 \\
0 \\
+\end{array}$ & 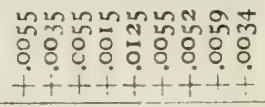 & $\begin{array}{l}\text { से } \\
\vdots \\
\dot{+} \\
+\end{array}$ & $\begin{array}{l}80 \\
80 \\
11\end{array}$ \\
\hline
\end{tabular}

แ| 3

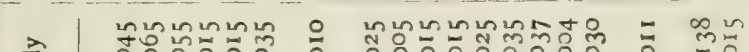

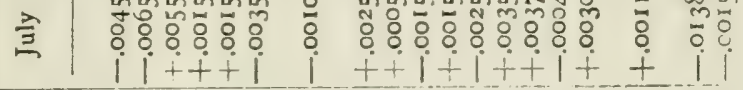

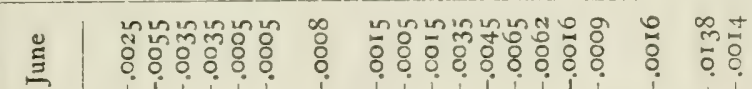
$+1+\dot{+}+\dot{+}+\dot{+}+\dot{+}+\dot{+}+\dot{+}+\dot{+}+\dot{t}$

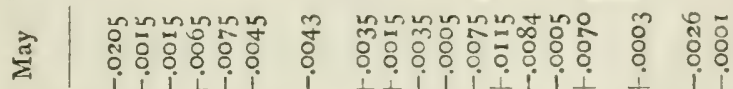
$i+i+i i$

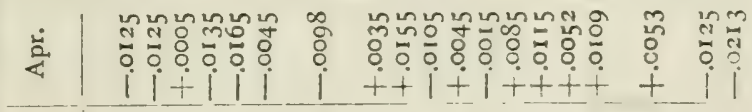

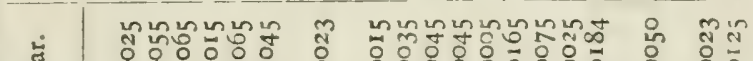

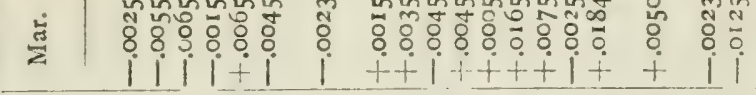

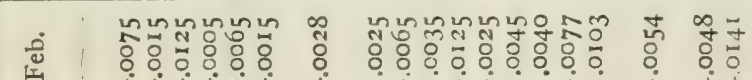

\section{i $i$ i i i i}


the quotations were based on actual sales. The significance of this table is more readily seen when the monthly averages for the first period and those of the second period are charted. This is done in diagram III.

It is seen that the averages of the monthly variations of the Elgin prices from the New York prices during the period from 1893 to 1898 are much lower on the whole than they are for the period from I9O3 to I9II. This fact is of course in agreement with the results shown in diagram II. While the prices during the period from 1903 to 1011 were on the whole considerably above the New York prices, the course of the prices throughout the year is the opposite from the course of the prices during the period from I893 to I898. In the first period prices were comparatively high in the summer, while in the second period they were low in the summer and comparatively high in the winter. The time for storing butter is during the months (if May, June, and July, and sometimes as late as August. It is during these months that the level of the Elgin prices as compared with the New York prices falls in the latter perind. The charge therefore that the Elgin quotation committee was dominated by the large centralizers and that they depressed prices in the summer months in order that they might buy butter and butter fat on a comparatively low basis and sell it in the fall and winter at a higher price, seems to be verified by the results of this comparison.

\section{WHOLESALE AND RETAIL PRICES COMPARED}

It is a familiar fact that wholesale prices fluctuate more widely than retail prices. Diagram IV. shows the course of retail and wholesale prices of butter in New York City.

The two price levels show rather close correspondence. There are of course some pronounced exceptions, the most notable being the drop in the wholesale price in February, 
Diagram IV. - Comparison of Retail and Wholesale Prices of Extra Creamery Butter in New York City from 1908 to Igif

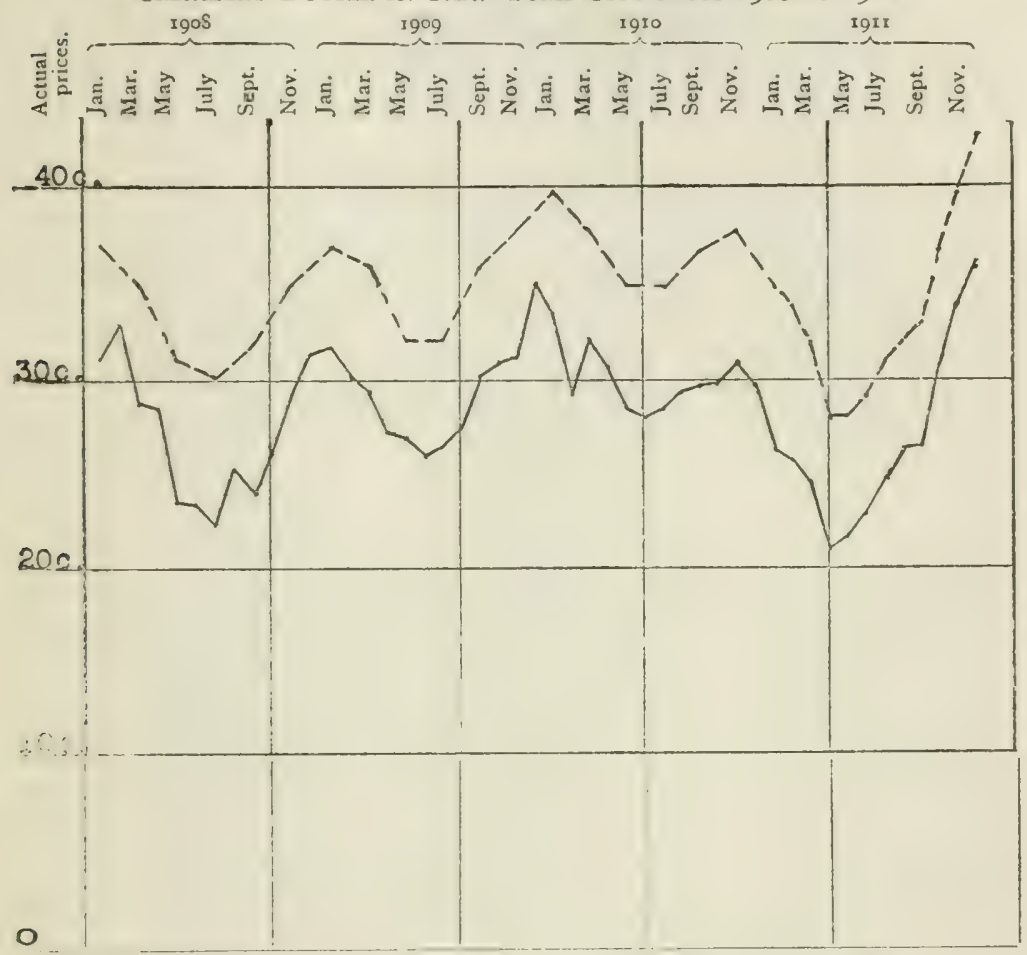

-. - Actual retail prices in New York City reported on the 15 th of each month.

Actual average monthly wholesale prices in New York City.

Data from U. S. Bureau of Labor Statistics, Bulletins 81, 87, 93, 99, 105.

I010, when the retail price shows merely a steady decline. In diccussing the organization of the butter market it was pointed out that the wholesale dealers make it their business to watch all conditions that affect prices, and for this reason it may be expected that the course of the wholesale prices will show small fluctuations to which the retail prices cannot respond. On the whole, however, the retail and 
Diagram V. - Comparison of Fluctuations in the Wholesale and Retall Prices of Butter

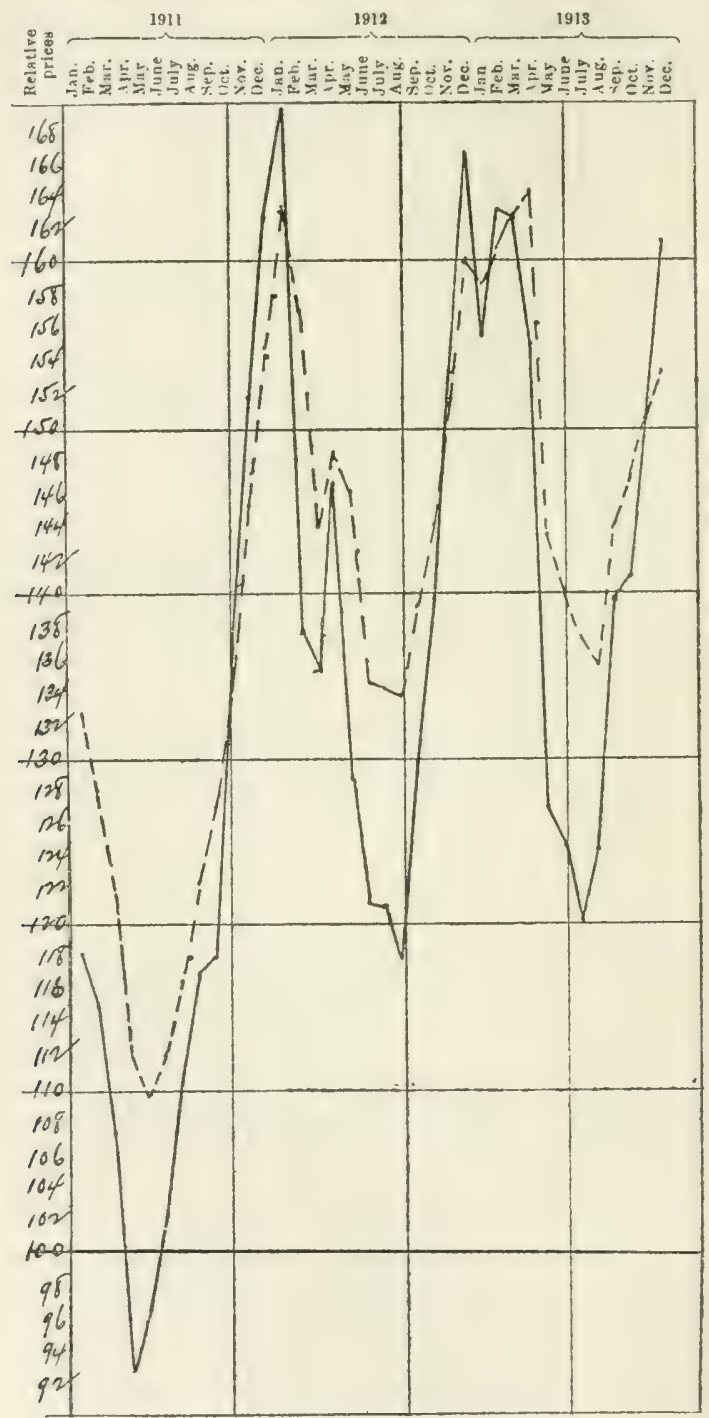

- - - Relative retail prices of creamery butter for North Atlantic Division.

City.

Relative wholesale prices of creamery butter for New York

Data from U. S. Bureau of Labor Statistics, Bulletins 99, II3, II4, 149. 
wholesale prices rise and fall together rather closely. This of course is due to the fact that the market is well organized in New York City where the retailer, jobber, and wholesale dealer, through whom the forces of competition can very sensitively vibrate, are in close touch with one another.

Another fact that becomes more apparent when relative prices are charted, is that wholesale prices rise and fall as a rule before the retail prices. This happens of course because the wholesale dealer takes the initiative in raising or lowering prices. Diagram V., on which relative retail prices for the North Atlantic Division and relative wholesale prices for New York City are charted, shows this fact.

\section{THE DIVISION OF THE CONSUMER'S PRICE}

Between the price paid to the farmer for the butter fat and the price paid by the consumer for fresh creamery butter there is a margin of about \$o.09. It may be more or less than this amount depending upon transportation charges and temporary conditions in the trade. This margin represents the cost of production at the creamery, the freight charges, local delivery charges, and the amounts taken by the wholesale dealers, jobbers, and retailers for receiving and passing the commodity to the consumer.

The United States Bureau of Labor Statistics has made an investigation of the division of butter prices paid by consumers, the results of which are published in Bulletin no. I64. Table no. I8 gives the average amounts of all the margins as well as the average price received by the farmer and the retailer during June and December for the years I904, I9IO, and I9II, of butter shipped from the North Central states to Cleveland, Pittsburgh. Cincinnati, and Philadelphia.

The average margin of the creamery for the year accord- 
ing to the table is $\$ 0.0258$. This is considerably less than the margin of the first creameries. For instance, in I880, the coöperative creamery at Hatfield, Me., made a contract with the operator to make butter for the succeeding year at $3 \frac{\mathrm{T} / 2}{2}$ cents per pound. The maker paid all expenses, including interest on stock. ${ }^{1}$ The introduction of improved ma-

TABLE XVIII

Amount and Per Cent of Items Composing the Average Retall Prices of Butter in the 3 Junes ANd 3 Decembers, 1904, I9IO, AND I9II, COMBINED

Average for 1904, 1910, and 1911

\begin{tabular}{|c|c|c|c|c|}
\hline \multirow[t]{2}{*}{ Item } & \multicolumn{2}{|c|}{ June } & \multicolumn{2}{|c|}{ December } \\
\hline & Amount & Per cent & Amount & Per cent \\
\hline Price received by farmer........ & $\$ 0.2056$ & 69.7 & $\$ 0.2785$ & \\
\hline Creamery margin............ & .0219 & 7.4 & .0298 & 7.9 \\
\hline Freight charges $\ldots \ldots \ldots \ldots \ldots$ & .0073 & 2.5 & .0073 & I.9 \\
\hline Cartage charges...$\ldots \ldots \ldots \ldots$. & .0003 &. $\bar{I}$ & .0003 &.$I$ \\
\hline Wholesale receiver's margin..... & .0149 & 5.0 & .0169 & 4.4 \\
\hline Retailer's margin............. & .0452 & $15 \cdot 3$ & .0463 & 12.2 \\
\hline Price paid by consumer......... & .2951 & 100.0 & .3791 & 100.0 \\
\hline $\begin{array}{l}\text { Total margin between consumer } \\
\text { and farmer.............. }\end{array}$ & .0895 & 30.3 & .1006 & 26.5 \\
\hline
\end{tabular}

(From Bulletin 164, Bureau of Labor Statistics, U. S. Department of Labor.)

chinery and scientific methods and the increase of the overrun, made it possible to manufacture at lower cost, and the keen competition in the dairy industry has narrowed the creamery margin, so that the share of the small creamery is probably only little more than the cost of production.

The table does not show any margin for the jobber who

${ }^{1}$ Report of Board of Agriculture of Maine for 1881 , p. I6. 


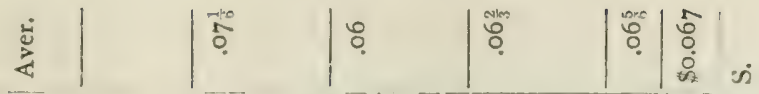

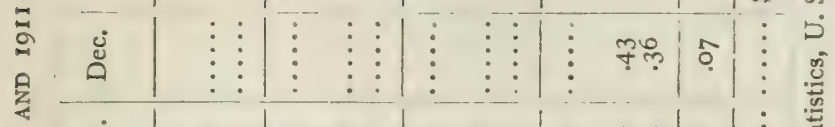

$$
\begin{aligned}
& \text { 임 } \\
& \text { 。ํ. }
\end{aligned}
$$

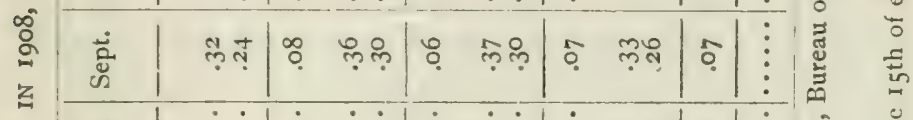

$$
\begin{aligned}
& \text { 至 } \\
& \text { 空 } \\
& \text { 觉 }
\end{aligned}
$$

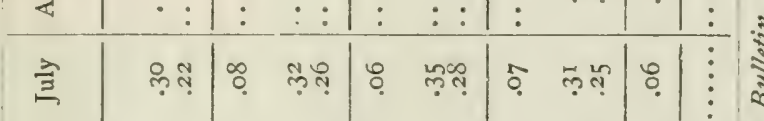

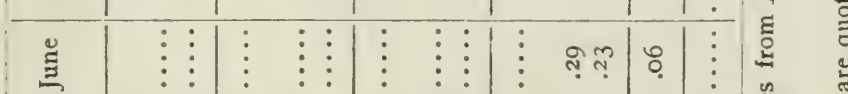


is ustrally an important middleman in all big cities. According to this study the average total margin received by the dealers in the city is \$o.0616. This of course is an average for June and December in three years. The dealer's margin is frequently larger and very often smaller. Large lots of butter are sometimes sold at a profit of a small fraction of a cent. Obstructions in the movement of freight sometimes cause a decided shrinkage in the receipts of butter for a week during which the price may rise, and the dealers having butter on hand at such a time can increase their margin considerably. Table no. I9 shows how the dealers' margin fluctuates.

The retail butter price is the price paid by the consumer, while the wholesale price is the amount paid by the wholesale dealer to the producer. The shipper, as a rule, unless he is a member of the Elgin Board of Trade, prepays transportation charges. The difference therefore between the retail and wholesale prices represents the dealers' margin. It must be remembered that a great deal of the butter is bought at a premium or at a price slightly higher than wholesale prices. This has the effect of reducing the wholesale dealers' margin. The total average of $\$ 0.067$ shown in table no. I9 as the dealers' share is therefore too high. Assuming that $\$ 0.0616$ is approximately the average total compensation received by the middlemen. the margins of the wholesale dealer, jobber, and retailer are probably very nearly $\$ 0.0125, \$ 0.0150$ and $\$ 0.0335$ respectively.

\section{SEASONAL PRICE FLUCTUATIONS}

Seasonal fluctuations are very pronounced in the price of butter due to seasonal variations in the amounts produced. The period of greatest production is during the months of May, June, and July. This is the time during which grass is at its best. The cows are turned into the 
pasture at this time and the result is a greatly increased flow of milk. In spite of the fact that a great many farmers have begun winter dairying - that is, have regulated the period of lactation so that the greatest part of the milk is produced during the winter when prices are high-the increased amount of milk during the early summer months

\section{TABLE XX}

Relative Monthly Prodiction, Marketings, and Prices of Butter

\begin{tabular}{|c|c|c|c|c|c|c|c|}
\hline \multirow[t]{2}{*}{ Month } & \multirow{2}{*}{$\begin{array}{l}\text { Mean } \\
\text { relative } \\
\text { monthly } \\
\text { production } \\
\text { in } 1910\end{array}$} & \multicolumn{3}{|c|}{$\begin{array}{l}\text { Mean relative monthly re- } \\
\text { ceipts (Chicago, New } \\
\text { York, Milwaukee, and } \\
\text { St. Louis.) }\end{array}$} & \multicolumn{3}{|c|}{$\begin{array}{l}\text { Mean relative price of } \\
\text { butter in } 13 \text { cities }\end{array}$} \\
\hline & & $1880-92$ & $1893^{-1901}$ & $1902-11$ & 1880-93 & $1893^{-1902}$ & $1902-11$ \\
\hline January... & 6.4 & $5 \cdot 7$ & 7.0 & 6.2 & 113.4 & 107.6 & 109.2 \\
\hline February & 5.5 & $5 \cdot 3$ & 6.4 & 5.8 & 113.6 & 105.0 & 108.9 \\
\hline March.... & 6.8 & 5.6 & 7.2 & 6.4 & 114.0 & 105.5 & 108.8 \\
\hline April..... & 7.9 & 6.0 & $7 \cdot 3$ & 6.4 & 108.2 & 98.3 & 103.0 \\
\hline May ...... & I1.0 & 7.9 & 9.1 & 8.6 & 90.2 & 88.9 & 94.1 \\
\hline June..... & 12.5 & 12.3 & 12.4 & 13.0 & 77.0 & 85.8 & 88.9 \\
\hline July....... & 10.6 & $\times 3.0$ & 11.0 & 12.5 & 77.8 & 86.9 & 88.8 \\
\hline August... & 9.6 & I1.0 & 9.2 & 10.4 & 85.0 & 91.5 & 91.8 \\
\hline September & 9.2 & 9.8 & 8.1 & 9.0 & 94.8 & 98.2 & 96.9 \\
\hline Octuber.. & 7.9 & 9.0 & 8.1 & 8.5 & 103.4 & 106.4 & 986 \\
\hline November & 6.5 & $7 \cdot 5$ & 7.0 & 6.8 & 109.6 & I 10.6 & 104.0 \\
\hline December $_{b}$ & 6.1 & 6.9 & 7.2 & 6.4 & 113.0 & II 2.1 & 109.2 \\
\hline
\end{tabular}

(From Bulletin IOI, Bureau of Statistics, U. S. Department of Agriculture.)

is still sufficient to depress the price in the summer as compared with prices in the winter when the production of milk is less. The heaviest of these three months is June. Table no. 20 shows the relative amounts of butter produced during the twelve months of the year, the relative

1 Record of 197 creameries well distributed geographically. Variations are to some extent determined by the varying number of days in the months. 
Diagram VI.-Seasonal Fluctuations in Receipts of Butter and the Wholesale Price at Chicago

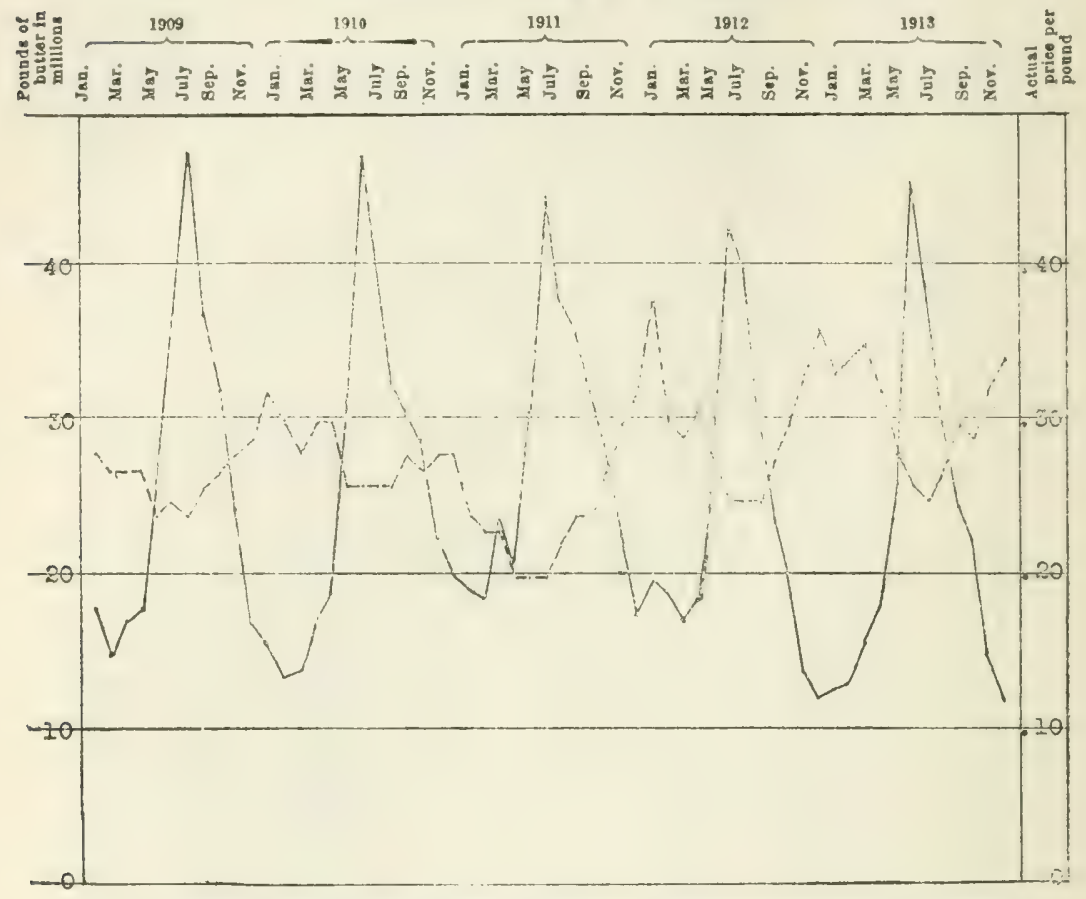

- - - Actual wholesale prices of butter, creamery extra, at Chicago. Receipts of butter at Chicago.

Data from Agricultural Yearbook.

receipts of butter at Chicago and other cities, and the mean relative wholesale prices in thirteen cities.

The table shows that February is the month of least production and that June is the month of greatest production. It also shows that receipts of butter at the big markets of the country vary very closely with the amounts produced. February is the month of least receipts and June the greatest. Prices vary somewhat closely with receipts. The table shows that prices varied much more closely with 
receipts in the first period than in the second and third periods. This is of course due to the fact that the course of prices is influenced considerably by the amount of butter in cold storage. The first period antedates the extensive use of refrigeration for the preservation of summer-made butter for winter consumption. Diagram VI. shows at a glance how prices fluctuate with variations in the amount of receipts.

As will be seen later, the amount of receipts is not the only important influence upon prices. Business depressions also very materially affect butter prices. When these occur the general price level of all commodities falls, and the price of butter is quite sensitive to the movement of prices in general. In I9I I, for instance, as seen in Diagram VI., the supply was not the only cause of the unusual drop in the price. There was a mild depression that year causing a fall in the general price level, and sympathetically causing also a fall in the price of butter.

Normal seasonal fluctuations are not as wide as they were formerly, due to the fact that speculators now place large quantities of butter in cold storage during the summer and turn it into consumption channels in the winter when production is comparatively low. The change of seasonal price fluctuations due to the use of cold storage since I893 may be seen in table no. $2 \mathrm{I}$.

Cold storage was not extensively used during the first period: and the mean monthly wholesale prices during this period are therefore considerably lower in June and higher in February than the prices for the same month in the second period during which large quantities of butter were stored.

A glance at Diagram VI. will show that speculators in placing butter in cold storage assume considerable risk. The price during the winter is not always higher than sum- 
mer prices. The butter stored in I9Io and sold during the following winter was disastrous to the dealers. The results of that year's speculation are shown in table no. 22 .

The average price for the storing season in I9Io was 28.08 cents, and the average price at which storage butter

\section{TABLE XXI}

Mean Wholesale Prices of Fresh and Cold-Storage butter AT New York City

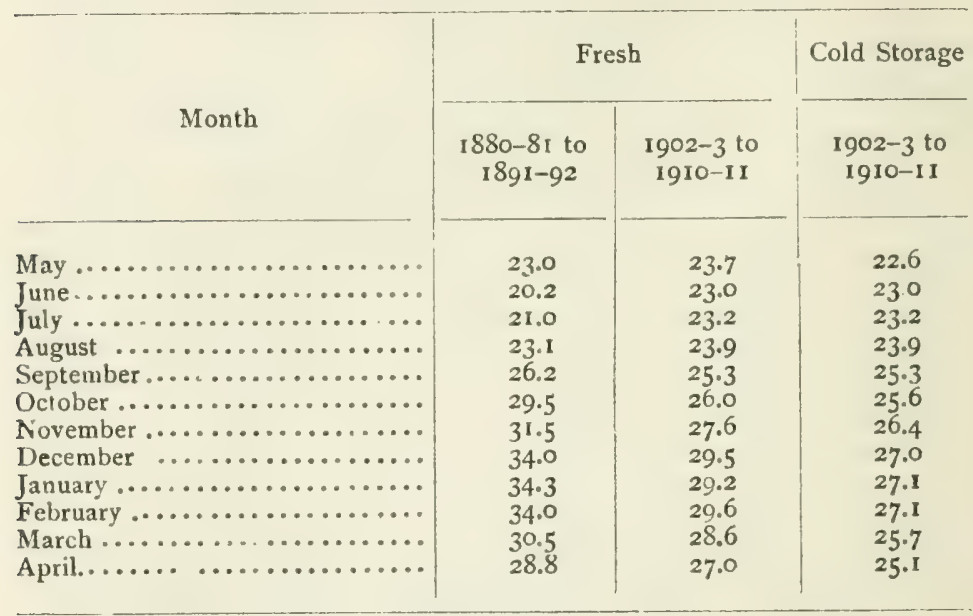

(From Bulletin 10I, U. S. Department of Agriculture, Bureau of Statistics.)

was sold was 25.58 cents. The difference between these two averages shows a loss to the speculator of 2.5 cents per pound. To this loss must be added the charges for storage, insurance, cartage, and interest on the money invested. The average total charge for storage, interest, and insurance is 2.532 cents per pound for 4.43 months ${ }^{1}$ - the average length of time butter is stored in the United States. The average total loss of the speculators in Igro was there-

1 Bulletin 93, U. S. Departmest of Agriculture, p. 44. 
fore about five cents per pound. Other years, however, frequently show an important profit from storing butter. For instance, butter bought in the summer of I9I I or I9I 2

\section{TABLE XXII}

Elgin Board Prices of Butter for June, July, and August 1910, AND FOR JaNuary, February, and March igII

\begin{tabular}{|c|c|c|c|}
\hline Date, storing season & $\begin{array}{l}\text { Price per } \\
\text { pound }\end{array}$ & Date, selling season & $\begin{array}{l}\text { Price per } \\
\text { pound }\end{array}$ \\
\hline 1910 & cents & 1911 & cents \\
\hline \multicolumn{2}{|c|}{ June $6 \ldots \ldots \ldots \ldots \ldots \ldots \ldots \ldots$} & \multicolumn{2}{|c|}{ January $9 . \ldots \ldots \ldots \ldots \ldots \ldots 29$} \\
\hline \multicolumn{2}{|c|}{ June $13 \ldots \ldots \ldots \ldots \ldots \ldots 27$} & \multicolumn{2}{|c|}{ January $16 \ldots . . \cdots \cdots \cdots \cdot 27$} \\
\hline \multirow{2}{*}{\multicolumn{2}{|c|}{$\begin{array}{l}\text { June } 20 \\
\text { June } 27 \\
\text { Ju}\end{array}$}} & \multirow{2}{*}{\multicolumn{2}{|c|}{ January $23 \ldots \ldots \cdots \cdots \cdots \cdots \cdots \cdots \cdot 25$}} \\
\hline & & \multirow{2}{*}{\multicolumn{2}{|c|}{ 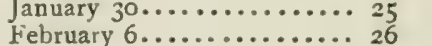 }} \\
\hline \multicolumn{2}{|c|}{ July $2 \ldots \ldots \cdots \cdots \cdots \cdots \cdots \cdots \cdots \cdot 277^{1 / 2}$} & & \\
\hline \multirow{2}{*}{\multicolumn{2}{|c|}{$\begin{array}{l}\text { July } \\
\text { J } 1, \ldots \ldots \cdots \cdots \cdots \cdots \cdots\end{array}$}} & \multicolumn{2}{|c|}{ February $13 \ldots \ldots \ldots \ldots \ldots 261 / 2$} \\
\hline & & \multicolumn{2}{|c|}{ February $20 . \ldots \ldots \ldots \ldots .261 / 2$} \\
\hline \multirow{2}{*}{\multicolumn{2}{|c|}{$\begin{array}{l}\text { July } 25, \ldots \ldots \cdots \cdots \cdots \\
\text { August I } \ldots \ldots \cdots \cdots \cdots\end{array}$}} & \multirow{2}{*}{\multicolumn{2}{|c|}{ 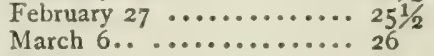 }} \\
\hline & & & \\
\hline \multicolumn{2}{|c|}{ August $8 \ldots \ldots \ldots \ldots \ldots . \ldots . \cdots 29$} & \multicolumn{2}{|c|}{ March $13 \ldots \ldots \ldots \ldots \ldots 26$} \\
\hline \multicolumn{2}{|c|}{ August $15 \ldots \ldots \ldots \ldots \ldots \ldots 29$} & \multicolumn{2}{|c|}{ March $20 \ldots \ldots \ldots \ldots \ldots .25$} \\
\hline \multicolumn{2}{|c|}{ August $22 \ldots \ldots \ldots \ldots \ldots 3^{0}$} & \multicolumn{2}{|c|}{ March $27 \ldots \ldots \ldots \ldots \ldots 24$} \\
\hline \multicolumn{2}{|c|}{ August $29 \ldots \ldots \ldots \ldots \ldots \ldots . \ldots .30$} & \multicolumn{2}{|c|}{ April $3 \ldots \ldots \ldots \ldots \ldots, 21$} \\
\hline \multicolumn{2}{|c|}{ Average ............ 28.08} & \multicolumn{2}{|c|}{ Average ............. $25.5^{8}$} \\
\hline
\end{tabular}

(From C.S. Department of Labor, Bureau of Labor Statistics, Bulletin I64, p. 23.) and sold in the succeeding winter brought a large return both years.

\section{MOVEMENT OF THE ANNUAL AVERAGE PRICE}

Diagram VII. shows that the prices of milk, butter, and cheese rise and fall at the same time. The fundamental causes affecting the price of milk affect also the price of butter and cheese. This is of course what might be expected because the producer in seeking high prices for milk will take his product to the creamery, or will ship it for consumption to the city where this is possible, or will take it to the cheese factory if one is accessible. The manufac- 
Diagram ViI.-Percentage Increase or Decrease in the Wholesale Prices of Milk, Butter, and Cheese at New York

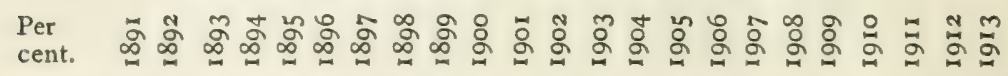

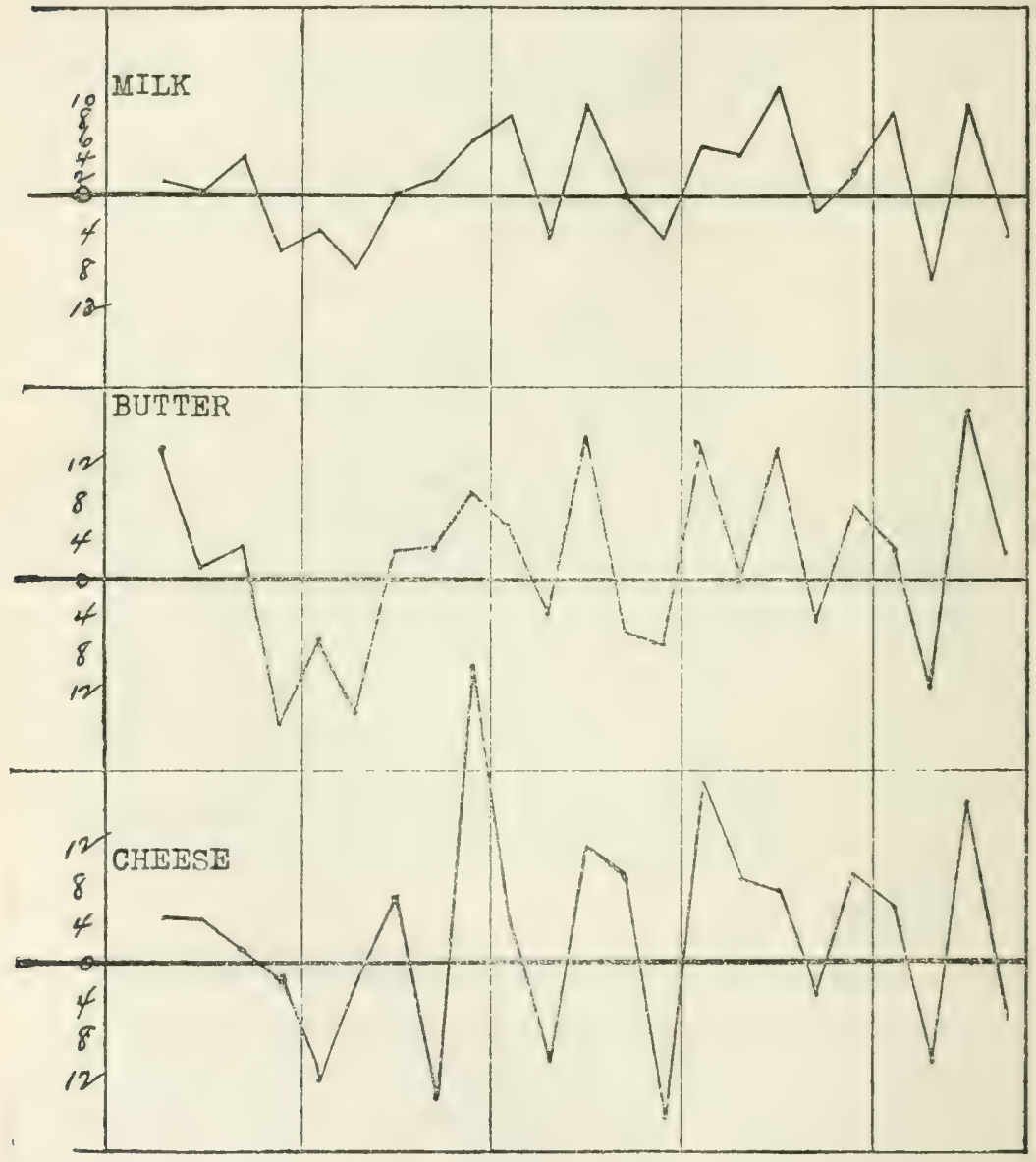

Drawn according to data from Bulletin I49, U. S. Bureau of Labor Statistics.

turers of cheese also frequently turn to butter-making when the price of cheese falls comparatively low. Creameries 
are also instaling machinery to make ice cream on a large scale and are rapidly succeeding in establishing firmly the habit of eating ice cream throughout rural districts. This innovation offers another form of dairy product into which milk may be converted. While the price of the three dairy products rise and fall at the same time, there is considerable difference in the extent of the fluctuation. Milk fluctuates less widely than butter and butter less widely than cheese. This is probably due to the fact that the amount of milk converted into butter and cheese sometimes causes an unequal situation between the supply and the demand of these two products. The manufacturer of cheese has considerable difficulty in judging prices because of the length of time required to ripen his product. The butter maker can place his product on the market from week to week or hold it in cold storage for the winter. Relatively there is fixity in the supply of cheese and flexibility in the supply of butter, and it is readily seen therefore why the fluctuations in the annual average price are greater for cheese than for butter.

To ascertain the causes of the variations in the amount of butter produced from year to year it would be necessary to have exact figures of the number of milch cows and all the amounts of milk, butter, and cheese produced for a series of years. If these figures were available for a limited, but representative area, they would probably show that the average yearly production of butter is largely determined by the price of feed and by the effect of prices upon dairy farming. Dairy farming is of course in competition with other types of farming, and the course of prices of the different farm products have probably a very important selective influence as to what type of farming shall be emphasized from year to year. The number of milch cows given in the Agricultural Yearbook do not change very abruptly, 
Diagram Viti.-Comparison of Receipts of Butter and Cheese at Chicago 들

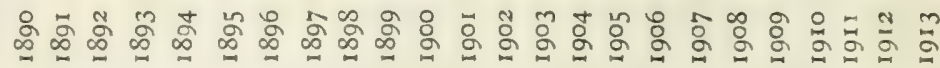

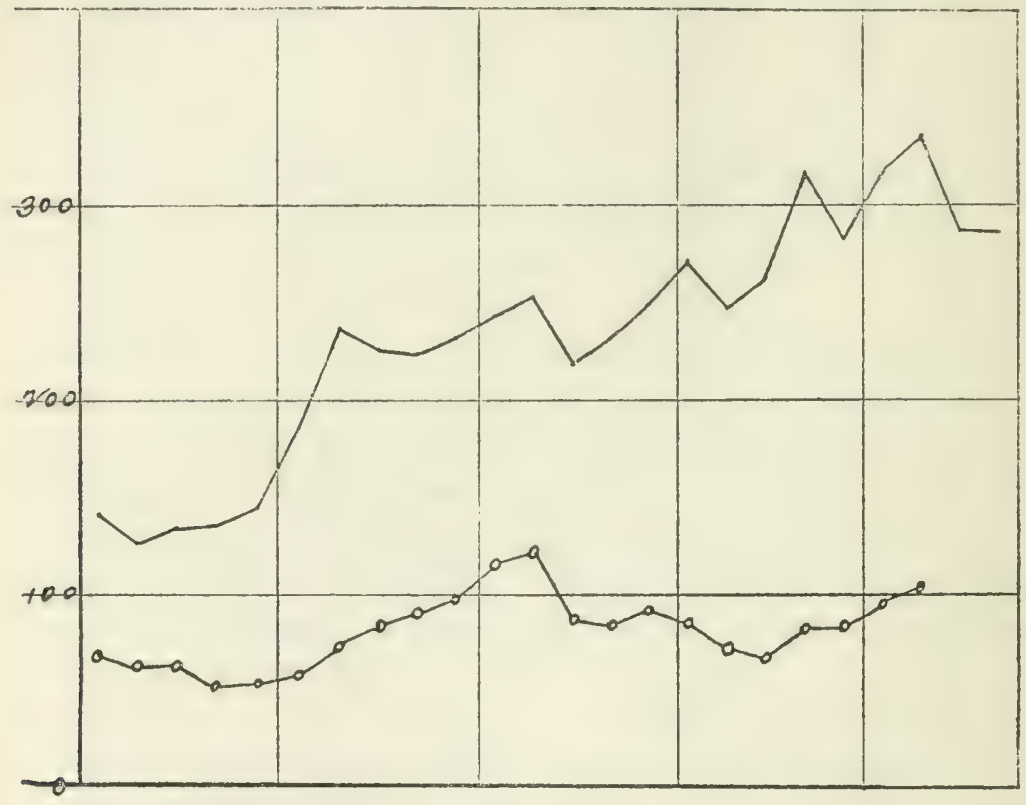

Receipts of butter at Chicago.

o- - Receipts of cheese at Chicago.

Drawn according to data from Reports of the Chicago Board of Trade. Figures for cheese for the years 1912 and I9I3 not available.

and these figures do not seem to indicate that important changes in yearly amounts of dairy products are due to changes in the number of milch corvs. An intensive study as to causes of the yearly changes in the amounts of dairy products, besides taking into account the number of milch cows in a given area, would also have to consider changes in the yield or flow of milk, because the cow is capable of showing an increase or decrease in the flow of milk accord- 
ing as the one or the other is encouraged by the farmer through his scheme of farm management for the year.

In view of the fact that Chicago is the distributing center for the butter produced in the North Central states-the butter belt of the country-the receipts of butter at Chicago must represent the movement of production. Diagram VIII. shows the fluctuation in the yearly receipts of butter and cheese at Chicago.

As previously stated there is a tendency for the supply of cheese to be more fixed than that of butter, owing to the fact that the supply of butter can be more readily adjusted to the price conditions. The diagram shows a general growth in the amount of butter passing through Chicago. Receipts of cheese increased from IS93 to I90I, decreased from I9OI to I907, and after I907 increased slightly. In America more attention is being paid to the manufacture of butter. The habit of eating cheese is growing in this country but the demand for this product in recent years has been largely satisfied by imports. A marked change in the exports and imports of cheese came in I902. Prior to that year the exports greatly exceeded imports, but after 1903 the imports steadily increased. In I9I 3 only a little over 2,000,000 pounds were exported while over 40,000,000 pounds were imported. ${ }^{1}$ This change in the export and import trade has an important effect upon the movement of cheese at Chicago, and explains why receipts of cheese show less growth than receipts of butter, in spite of the fact that the per capita consumption of cheese has increased. The following statement shows the relation of these two dairy products both as to per capita production ${ }^{2}$ and per capita consumption: ${ }^{3}$

${ }_{1}$ Reports of Foreign Commerce and Navigation of the United States.

2 From Bulletin I77. U. S. Department of Agriculture, by Eugene Merritt.

${ }^{3}$ Computed from Census and Reports of Foreign Commerce and Navigation of the United States. 
I9IO $\quad 1900 \quad I 890 \quad I 880$

Pounds. Pounds. Pounds. Pounds.

Per capita production of butter... 17.6

I9.6 I9.I I6.I

Per capita consumption of butter.. 17.5

I9.4 $\quad 18.7 \quad 16.8$

$\begin{array}{llllll}\text { Per capita production of cheese... } & 3.5 & 3.9 & 4.1 & 4.8\end{array}$

$\begin{array}{lllll}\text { Per capita consumption of cheese } . & 3.9 & 3.5 & 2.7 & \mathbf{2 . 3}\end{array}$

It is seen that both the per capita production and consumption of butter run almost parallel. Per capita consumption rises from 16.8 pounds in 1880 to 19.4 pounds in 1900 and declines to 17.5 pounds in I9I0. The figures indicate that the production of butter in recent years has not kept pace with the increase of population. The por capita production of cheese has steadily declined from I 880 to I9Io, but the per capita consumption of cheese has steadily increased during this period. The excess of consumption of cheese over production has been supplied by imports in recent years.

In view of the fact that figures showing production of dairy products are not available for a long series of years, it is difficult to show the causes of changes in the yearly amounts produced as well as the exact relation between amounts produced and prices. It is believed, however, that the receipts of butter at Chicago show fairly well the changes in production. Approximately 75 per cent of the butter shipped into Chicago is reshipped and distributed throughout the country. In the North Central states, in I9I0, an excess of about $325,000,000$ pounds over the amount consumed was produced. About 200,000,000 pounds ${ }^{1}$ of this quantity was consumed in the North Atlantic states and the remainder in the South and West.

The receipts of butter at Chicago have therefore been taken to represent the supply, and to present clearly the relation of supply to prices table no. 23 has been con-

${ }^{1}$ Bulletin I77, U. S. Department of Agriculture, by Eugene Merritt. 
structed. The actual receipts of butter have been converted into index numbers, and the moving average and the deviations from the moving average have been computed.

TABLE XXIII

Relation of Supply of Butter to Prices

\begin{tabular}{|c|c|c|c|c|c|c|}
\hline \multicolumn{4}{|c|}{ Supply } & \multicolumn{3}{|c|}{ Price } \\
\hline Date & $\begin{array}{c}\text { Index } \\
\text { of } \\
\text { supply }\end{array}$ & $\begin{array}{l}\text { Moving } \\
\text { average of } \\
\text { indices }\end{array}$ & $\begin{array}{l}\text { Deviations } \\
\text { from moving } \\
\text { average }\end{array}$ & $\begin{array}{c}\text { Index } \\
\text { of } \\
\text { supply }\end{array}$ & $\begin{array}{c}\text { Moving } \\
\text { average of } \\
\text { indices }\end{array}$ & $\begin{array}{l}\text { Deviations } \\
\text { from moving } \\
\text { average }\end{array}$ \\
\hline I $890 \ldots . .$. & 60 & & & 93 & & \\
\hline $1891 \ldots \ldots \ldots$ & 55 & & & 104 & & \\
\hline $1892 \ldots \ldots \ldots$ & 58 & 59 & -1 & 105 & 100 & 5 \\
\hline $1893 \ldots \ldots \ldots$ & $5^{8}$ & 62 & -4 & 107 & 99 & 8 \\
\hline $1894 \ldots \ldots \ldots$ & 62 & 72 & -10 & $9 \mathrm{I}$ & 93 & -2 \\
\hline $1895 \ldots \ldots \ldots$ & 79 & 80 & $-I$ & 86 & 87 & -1 \\
\hline $1896 \ldots \ldots \ldots$ & 102 & 87 & 15 & 74 & 81 & -7 \\
\hline $1897 \ldots \ldots \ldots$ & 97 & 94 & 3 & 76 & 80 & -4 \\
\hline $1898 \ldots \ldots \ldots$ & 95 & 100 & -5 & 78 & 81 & -3 \\
\hline $1899 \ldots \ldots \ldots$ & 99 & ror & -2 & 86 & 84 & 2 \\
\hline $1900 \ldots \ldots$. & 105 & 100 & 5 & 90 & 88 & 2 \\
\hline $1901 \ldots . .$. & 109 & IOI & 8 & 88 & 92 & -4 \\
\hline $1902 . . . \ldots$. & 94 & 103 & -9 & 100 & 93 & 7 \\
\hline $1903 \ldots \ldots$ & 100 & 105 & -5 & 96 & 95 & I \\
\hline $1904 \ldots \ldots \ldots$ & 107 & 105 & 2 & go & 98 & -8 \\
\hline $1905 \ldots \ldots \ldots$ & 117 & 109 & 8 & IOI & ror & 0 \\
\hline $1906 . . . .$. & 107 & 116 & $\rightarrow 9$ & 102 & 104 & -2 \\
\hline $3907 \ldots \ldots \ldots$ & $1 \times 3$ & II 9 & -6 & 115 & I 10 & 5 \\
\hline $1908 \ldots . .$. & 136 & 123 & 13 & 112 & II 5 & -3 \\
\hline $1909 . \ldots \ldots$. & 122 & 130 & -8 & 120 & 116 & 4 \\
\hline $1910 \ldots . . .$. & I 37 & 132 & 5 & 124 & I1 8 & 6 \\
\hline $1911 \ldots . . .$. & 144 & 130 & 14 & 110 & $12 \mathrm{I}$ & $-1 I$ \\
\hline $1912 \ldots \ldots \ldots$ & 123 & & & 123 & & \\
\hline $1913 \ldots \ldots$ & 123 & & & 128 & & \\
\hline Aver......... & 100 & & & 100 & & \\
\hline
\end{tabular}

(Computations of supply based on receipts of butter at Chicago as recorded in the Report of the Chicago Board of Trade for 1913. Price computations based on actual Elgin prices given in U. S. Bureau of Labor Statistics, Bulletin 149.)

The Elgin wholesale prices have been treated similarly. If the results of these computations are charted the relations between supply and price may be seen at a glance. 
Diagram IX.-Comparison of Supply of Butter and Annual Average Prices

\section{Percent-}

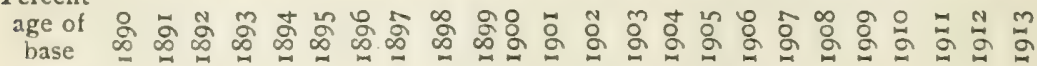

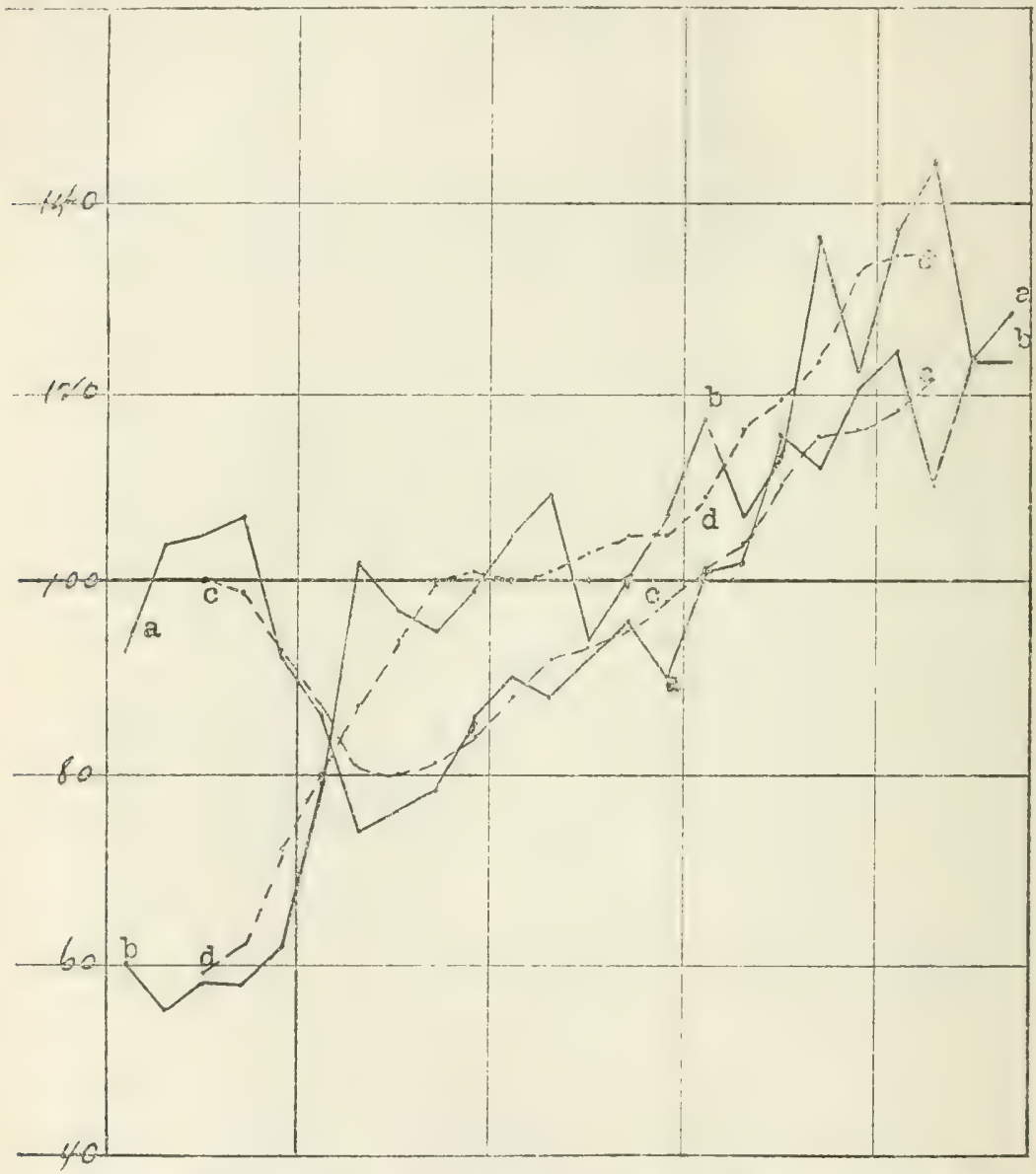

a-Price index. b-Supply index. c-Moving average of price. d-Moving average of supply.

Drawn from data in Table no. 23. 
It is readily seen that long-period fluctuations in the price correlate rather closely with changes in the amount produced. Especially is this noticeable when the early part of the period is compared with the period following the year 1895 .

The degree of correlation between short-period or annual fluctuations of supply and price may be more readily seen

Diagram X.-Fluctuations in Supply and Price of Butter

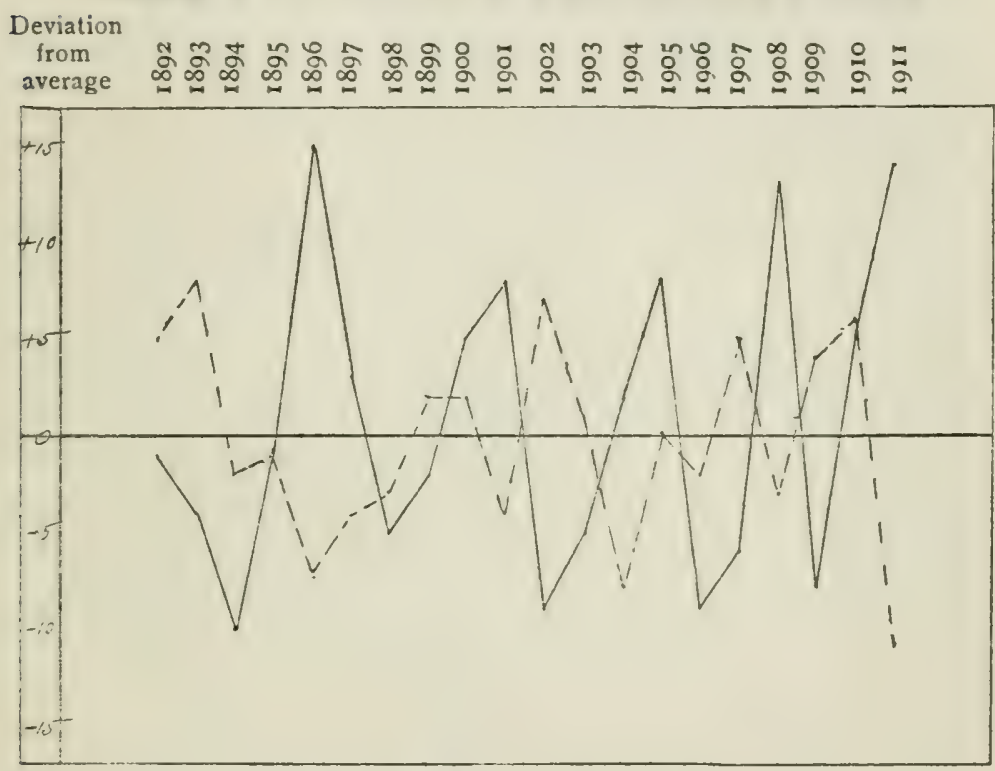

- Receipts of butter at Chicago.

- - - Elgin price of extra creamery butter.

Drawn according to computations in Table No. 23.

by charting the deviations of the supply and price from their moving averages.

It cannot be said that there is a close correlation between the supply of butter and prices. The most notable inverse correlations occur in I9II, 1908, 1902, 1901, and 1896. 
As will be seen later, however, the supply during these years was by no means the only force that acted upon prices. In I9II, I908, and I896, there were business depressions during which the prices of all commodities fell and the price of butter was not an exception. In I9OI, the general price level also fell slightly and the increase in the supply was therefore not the only cause depressing the price of butter for that year. In 1902, there was great prosperity and this aided in raising the price. It is seen therefore that the forces of supply and business conditions frequently act in conjunction in causing fluctuations in the price.

Oleomargarine must also be considered as a part of the supply of butter in treating butter prices. In diagram XI. the receipts of butter at Chicago, the yearly amounts of oleomargarine consumed in the United States and the Elgin prices of butter are shown. The administration of federal and state legislation interfered considerably with the production and sale of oleomargarine. In 1902, for instance, the federal law taxing colored oleomargarine was passed and this law no doubt had a serious effect upon the amount produced and consumed in the United States. However, the course of the graph shows clearly enough that the consumption of oleomargarine decreases when the price of butter is low and increases when the price is unusually high. This was the tendency from I 890 to 1902 , and also from I909 to I9I3. Immediately after 1902 the manufacturer of oleomargarine was not only hampered in his operations by the administration of the new law, but was in strong competition with low prices for butter. When the butter prices began to rise again in 1905 the consumption of oleomargarine began to increase. It thus appears that oleomargarine in some measure acts as an equilibrator upon the price of butter. The relation that oleomargarine bears to the supply and price of butter would also seem to show that 
Diagram XI.-Comparison of the Consumption of Oleomargarine and Prices OF BUTtER

(Average price for $1890-1899=100.0$ )

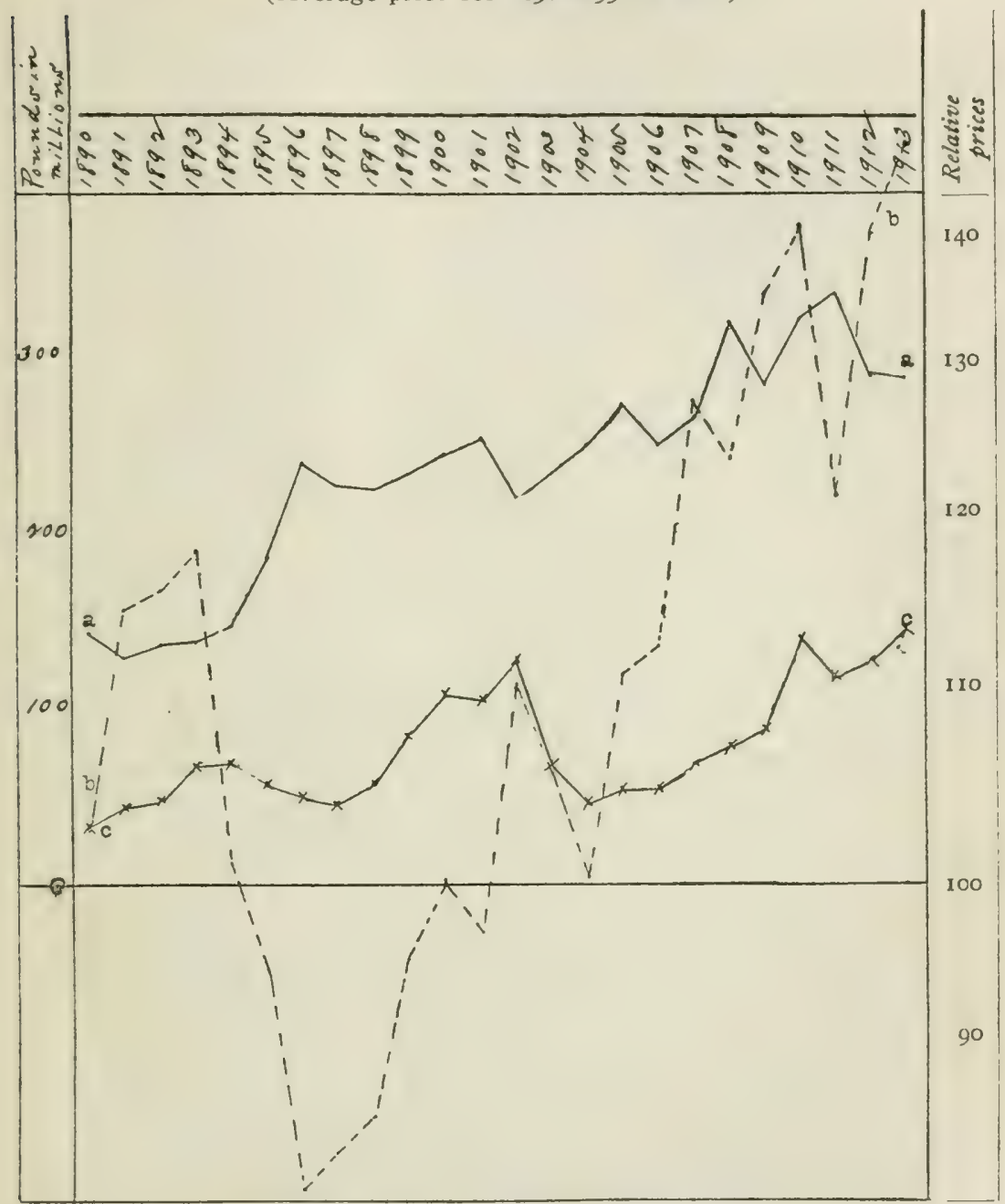

a-Receipts of butter at Chicago by calendar years.

b-Relative wholesale prices of Elgin creamery butter.

c-Amounts of oleomargarine consumed in the United States by fiscal yearsJuly I to June 30.

Receipts of butter from Report of the Chicago Board of Trade. Figures for oleomargarine from Reports of the U. S. Internal Revenue Commissioner. Prices from Bulletin I49, U. S. Bureau of Labor Statistics. 
the demand for butter or for a fat to be used as a spread for bread is relatively stable.

Diagram XII. is presented to locate at a glance the periods of prosperity and depression, the points of high and low production of butter, and the fluctuations in the price. With the exception of the three years, I89r to I893, when production was comparatively low, there is a very close direct correlation between the price level of all commodities and the price of butter. In fact this correlation is closer than the inverse correlation between the supply and price. Fluctuations of the general price level are caused principally by business conditions. Prices begin to fall when crises occur and usually reach their lowest point toward the close of the "subsequent period of depression". ${ }^{1}$ They rise during periods of prosperity. The price of butter seems to be especially sensitive to these business cycles. The consumption of butter does not decrease during times of depression. The facts charted on diagram XI., showing the consumption of oleomargarine in the United States, seems to indicate that the consumption of butter tends to decline during periods of prosperity and high prices, and to increase during periods of depression and low prices. Oleomargarine takes the place of butter when prices are high and gives way to butter when prices are low.

The evidence seems to show that fluctuations in the seasonal price are determined mainly by changes in the amount produced. Long-period fluctuations in the price also correlate somewhat closely with long-period changes in the amount produced. Fluctuations in the annual average price, however, are due to changes in the supply of butter and oleomargarine on the one hand and to business conditions on the other, the dominant force being business conditions.

${ }^{1}$ W. C. Mitchell, Business Cycles, p. 558. 
Diagram XiI.-Comparison of Butter Prices with the General Price Level (Average price for $1890-1899=100.0$ )

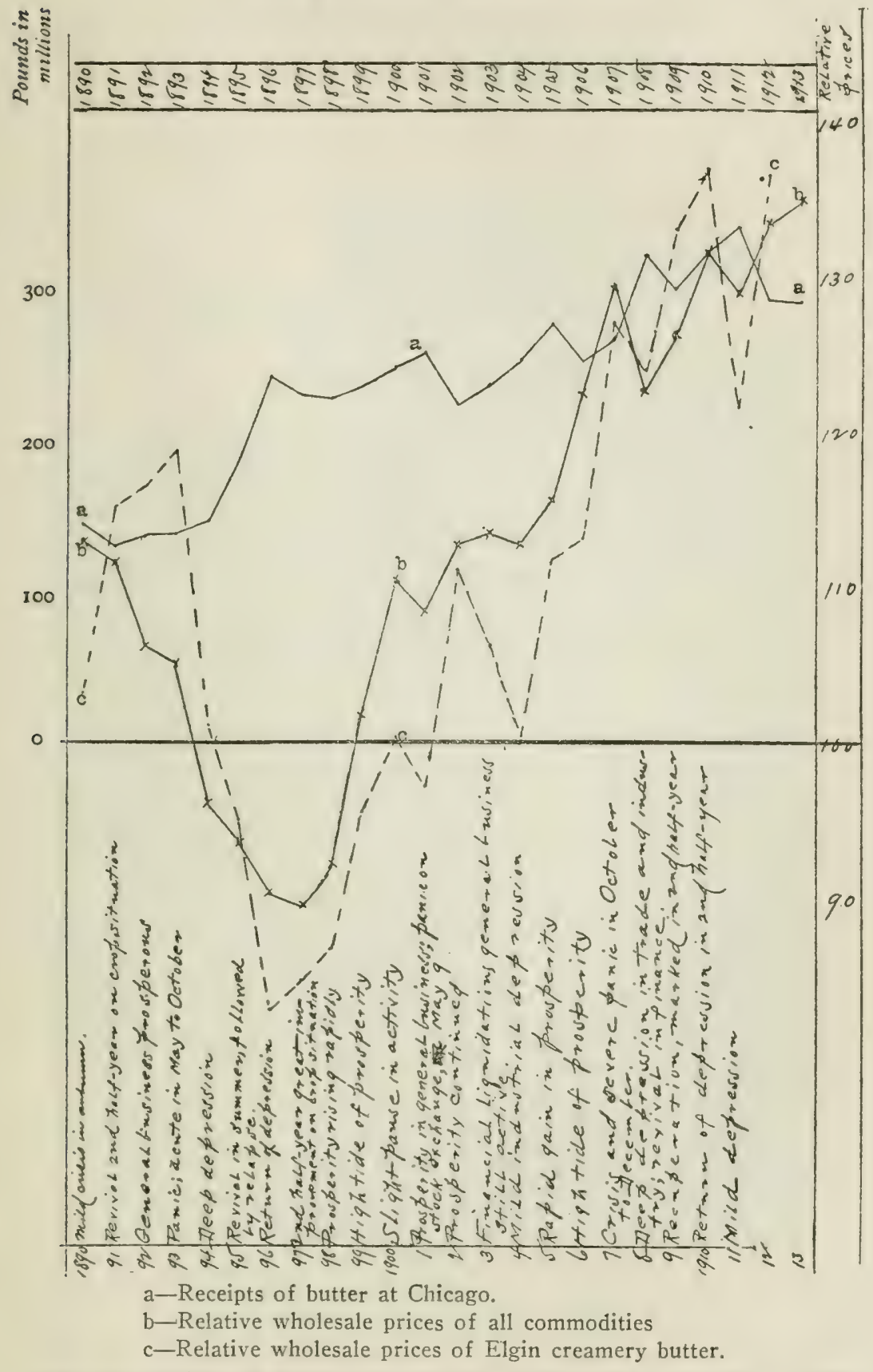

Data for receipts of butter from Report of the Chicago Board of Trade. Relative prices from Bulletin I49, U. S. Bureau of Labor Statistics. Summary of business conditions from Business Cycles, by W. C. Mitchell (p. 88). 


\section{CHAPTER IX}

\section{Adulteration and Oleomargarine}

\section{ADULTERATION OF FOODS}

THE adulteration of dairy products is only a special phase of the adulteration of food products in general. In dairy products adulteration is comparatively simple and in these the evil has therefore been probably more glaring than in many other foods. Before the enactment of our dairy laws and the use of the Babcock test milk was frequently diluted with water. This was the earliest form of dairy adulteration and has been practised by many a dairyman and dairywoman in the centuries that have gone by. The manufacture of "full cream cheese" from skim milk, the filling of cheese with lard, the substitution of oleomargarine for butter and the use of deleterious preservatives in renovating rancid and deteriorated butter, have also been more or less generally practised in America and Europe. "The following list ${ }^{1}$ of the most common adulterants met with in the principal food products is compiled from the State Board of Health, the returns of the English Inland Revenue Department, and of the Report of the Municipal Laboratory of Paris":

${ }^{1}$ Report of U.S. Commissioner of Internal Revenue for 1888 , p. clxxxvi. 
Food Products and thelr Chief adulterants

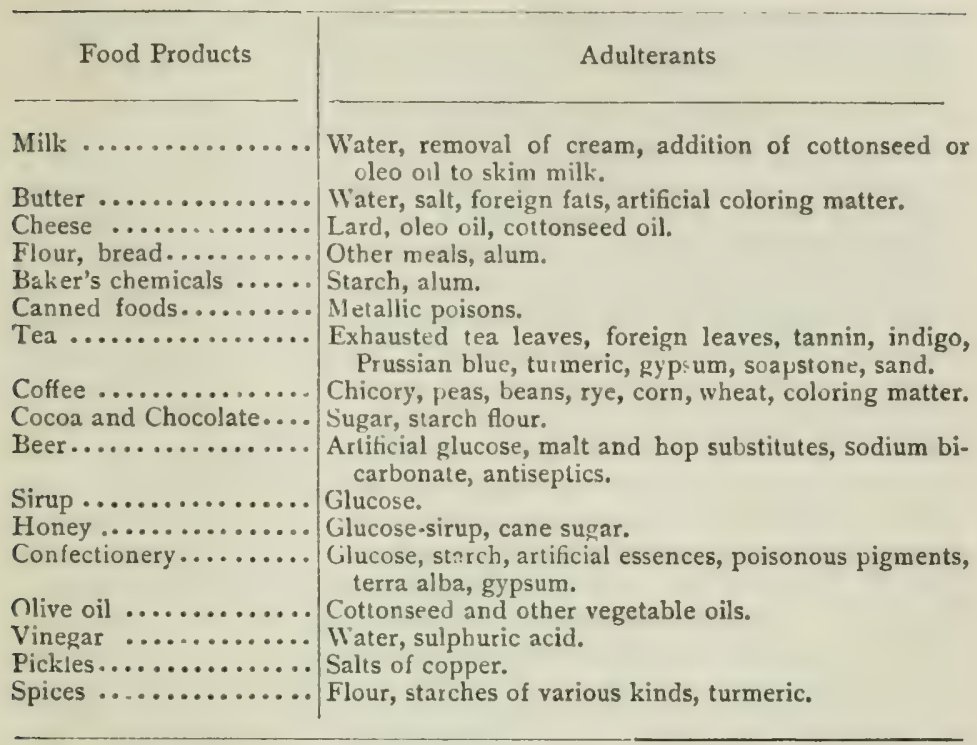

A very adequate presentation of the extent of adulteration of food products in general, is given by Prof. H. C. Adams in his report as Dairy and Food Commissioner of Wisconsin in $1902 .{ }^{1}$ It is as follows:

Men cannot be made honest by law, but law can make dishonesty pay a penalty when it steals the livery of honest products to serve a dishonest purpose. In every civilized land, and in a few where civilization is not as radiant as in our own, fierce competition and unbridled greed have unclertaken to profit by the adulteration of nearly every article of food used by the human family. As in every other department of human effort, there has been wonderful progress during the last half century. The clumsy wooden nutmeg of Connecticut, that even a policeman might detect, has given way to artificial eggs which no hen would recognize and to artificial butter that never

\section{Page 56.}


knew milk. The universal demand for cheap things brings a supply. Wheat flour is adulterated with corn flour; buckwheat with wheat middlings. Vermont maple syrup is made that never saw Vermont, and is made from the sap of trees that grow in the heart of Chicago. Glucose has dethroned cane syrup. Cider vinegar is distilled from grain. A good portion of the strained honey of commerce never produced any strain upon the bees. Milk is robbed of its cream, filled with lard and sent all over the world to ruin the reputation of American Cheese. Borax and formaldehyde go into milk to kill babies and weaken invalids. Oysters are practically embalmed with chemicals. Lemon extracts are made without lemon oil and vanilla extracts without vanilla. The hogs of the North compete with the cheap cotton-seed oil of the South, and mix in the same tub under the banner of lard. Artificial smoke is made for hams out of poisonous drugs. Jellies colored in imitation of the natural fruits and sold as fruit jellies flood the market, although they are almost as destitute of fruit juice as a bar of pig iron. The embalmed beef business has been exaggerated, but we do not need any either for soldiers or civilians. Canned fruit is preserved with antiseptics, which delay the digestive processes. Baking powders under misleading names crowd the markets. Spices enriched with pepper hulls and ground cocoanut shells are manufactured and sold by the ton. The close partnership which has existed for so many years between coffee and chicory does a thriving business in many states under the firm name of coffee. Cheapness is secured by these adulterations and false labeling, but the people are defrauded.

Pefore Prof. Adams wrote the above paragraph a number of states had enacted dairy laws prohibiting the adulteration of dairy products and in I 886 the government followed with a federal law regulating the manufacture of leomargarine and the renovating of butter. The legislation on the adulteration of dairy products was followed in 
many states by legislation concerning the adulteration of other foods. By 1906, the pure-food idea had swept over the country and in that year a federal pure-food law was passed. Since then, federal bureaus and state dairy and food commissioners have inspected food products and have rigorously prosecuted offenders of the law. As a result of this government interference foods are much purer to-day than they were formerly, and, with the exception of a few products, are as a rule sold for what they actually are. The picture of the adulteration of foods as drawn by Prof. Adams in 1902 is therefore more historical than indicative of present conditions.

The first adulteration of dairy products that assumed the proportions of a social problem in America occurred about I 840 in connection with the production of milk for fresh consumption in cities. ${ }^{1}$ It had become very common in New York City, in other large American cities, and in European cities to erect stables near distilleries and feed cattle on distiller's slops. The milk produced a very low percentage of fat and was drawn from cows housed in filthy stalls. The cows were frequently diseased because of the improper feed they received and because of the very careless and unsanitary conditions under which they were kept. The milk, after it passed to the city dealer or peddler, was further diluted, making its food value very inferior, and to babies very dangerous. In the interest of the consuming public the problem was taken up by reformers who called attention to the great dangers lurking in the "swill milk"." In I844, the Orange County Milk Asso-

${ }^{1}$ Vide, John Mullaly, The Milk Trade in Nerw York and Vicinity.

${ }^{2}$ Robert M. Hartley, one of the founders of the New York Association for Improving the Condition of the Poor, was prominent in the agitation for pure milk. Vide, Report of Milk Conference Called by the Association, p. 3 . 
ciation ${ }^{1}$ was organized to furnish pure milk in opposition to the poor grade of milk produced at distilleries. The Erie railroad had not yet developed order and regularity in its deliveries and as a result the milk from Orange County was not always available.

In IS62, the state of New York passed a law prohibiting the production of unwholesome milk and its achulteration. This lav was amended in I864, and subsequent laws were passed in $186_{5}$, IS7S, and ISS2; but the adulteration of milk in New York City remained a menacing evil until I $88_{4},{ }^{2}$ when the office of Dairy Commissioner was established. This office provided the necessary machinery to enforce the law. A dairy fraud that stirred the people about as much as the production and sale of impure milk was the introduction of oleomargarine and selling it for butter. Agitation for laws against this traffic originated among the dairymen and was propagated by them.

\section{HISTORY OF OLEOMARGARINE}

The word oleomargarine is made up of the two words, oleic and margarin. Oleic is the adjectival form of oleum which is the Latin for oil. The definition of oleic is: pertaining to or derived from oil. ${ }^{3}$ In its combining form this word is spelled olco. Thus, we have the words, oleophosphoric acid, oleo-palmitin, oleo-stearin, ctc. Margarin or margarine is derived from the word margaric, which is the name given by Chevreul to one of the three fatty acids (oleic, margaric, stearic), the glyceryl derivatives of which (olein, margarin, stearin) were thought by him to form the chief constituents of animal fat. Nargarine has since

1 John Mullaly, The Milk Trade in New York and Vicinity, p. 105.

'Vide, Laws of New York, I862, p. 866; I864, p. II95; I865, p. 472; 1878, p. 274; 1884, p. 255.

${ }^{3} V$ ide, Standard and New English dictionaries. 
been shown, however, to be a mixture of stearin and palmitin. ${ }^{1}$ Stearin is the hardest of these constituents, and inasmuch as the manufacture of oleomargarine involved the separation of most of the stearin from olein and margarine, according to the belief that olein and margarine were separate and distinct substances, the combination of these two could properly be called oleomargarine. In England, France and Germany, the product is known as " margarine", but in America as oleomargarine. Oleomargarine may be defined as an artificial butter made chiefly from animal and vegetable fats churned with milk to give it the butter flavor. The federal oleomargarine law of August 2, I886, section 2, defines oleomargarine as follows:

That for the purposes of this act certain manufactured substances, certain extracts, and certain mixtures and compounds, including such mixtures and compounds with butter, shall be known and designated as "Oleomargarine," namely: All substances heretofore known as oleomargarine, olco, oleomargarine oil, butterine, lardine, suine, and neutral; all mixtures and compounds of oleomargarine, oleo, olcomargarine-oil, butterine, lardine, suine and neutral; all lard extracts and tallow extracts and all mixtures and compounds of tallow, beeffat, suet, lard, lard-oil, vcgetable oil, annotto, and other coloring matter, intestinal fat, and offal fat made in initation or semblance of butter, or when so made, calculated or intended to be sold as butter or for butter.

The formula for the manufacture of oleomargarine was worked out by M. Mége Mouries, a Parisian chemist, in I $867 .{ }^{2}$ Napoleon III. of France offered a prize for the discovery of a process by which an artificial butter could be

\section{${ }^{1}$ New English Dictionary.}

${ }^{2}$ Report of the U.S. Commissioner of Internal Revenue for 1887, p. cli. 
made for the use of the navy and the poor people. The requisites of the product were that it must be cheaper and must keep from getting rancid longer than real butter. Both of these conditions were met by M. Mége in his product to the satisfaction of the French authorities. The hypothesis that led to the discovery of this process for making oleomargarine postulated that the butter fat in milk is secreted by the fatty tissue of the cow, and that if this fat could be properly separated from the tissue of a slaughtered animal the same product could be obtained as is produced in churning the butter fat in milk. M. Mége performed his experiments on the Imperial farm at Vincennes. ${ }^{1}$ The process ${ }^{2}$ he ultimately adopted consisted of heating finely-minced beef with water, carbonate of potash, and fresh sheep's stomachs. The mixture was raised to a temperature of II 3 degrees $F$. The pepsin contained in the sheep's stomach and the heat separated the fat from the cellular tissue. By subjecting the fatty matter to hydraulic pressure the softer oils were separated from the stearin. This oil, now generally called oleo oil, was mixed in the proportion of Io lbs. of the oil with 4 pints of milk, 3 pints of water, and a small quantity of annotto to color it. The whole was then churned and produced a product very much like butter. Since then many modifications of this process have been made. In 1870 , a factory for the production of "margarine" was in operation at Poissy, near Paris. During the time of the Franco-Prussian war the factory suspended operations, but at the cessation of hostilities they were resumed. ${ }^{3}$

"In April, I872, the Council of Health of the Depart-

${ }^{1}$ Report of U. S. Internal Revenue Commissioner for 1887 , p. cli.

${ }^{2}$ Encyclopedia Britannica.

3 Report, op. cit., p. cli. 
ment of the Seine, on the favorable report of M. Felix Baudet, admitted the new product to the trade under the provision that it must not be sold as butter." I Following are extracts from Baudet's report: ${ }^{2}$

This artificial butter presents then this advantage, that it contains much less water and animal substance which makes the ordinary commercial butter rancid; moreover, for the same weight it furnishes more genuine butter. These two circumstances assist without doubt in its preservation which is much more perfect than that of common butter. They also prevent it from acquiring the odor and the acridity which are soon developed in the latter.

During warm weather when ordinary butter can with diffculty be preserved from melting, it is easy to give to the artificial butter a more or less solid consistence by preparing an oleomargarine more or less free from stearin.

The experiments which I have witnessed in the works of M. Mége, those which I have myself made or which have been made at my instance on the new products which he has brought forward, authorize me to believe that he has realized a happy application of his knowledge and his inventive genius in the employment of beef fat, and that he has furnished for consumption two rew and important products.

The first, called cooking grease or oleomargarine, offers a valuable material for cooking purposes, especially for naval vessels during long voyages by reason of its good quality and of its capability of long and excellent preservation.

The second, possessed of properties which allow of its close comparison with butter in a chemical point of view, as well as regards its uses, may take the place of the latter in many instances, and in consequence of the small expense at which it can be made, it has been put in competition with milk butter

${ }^{1}$ Report of U. S. Internal Revenue Commissioner for 1887, p. cli.

${ }^{2}$ Second Annual Report of the New York State Dairy Commissioner, p. 316. 
which will lower necessarily the price of the latter to the benefit of the consumer which will render the consumption of it less considerable and will allow the breeders to devote a much grcater quantity of milk to the raising of calves, a great advantage to their industry.

As regards healthfulness it is evident that the origin and preparation of these two products presented by M. Mége, do not afford any circumstance which can render their employment a matter of suspicion.

There is then no reason for opposing the sale of these products if we include the proviso that that which M. Mége Mouries compares to butter is not really butter in the usual and true acceptation of the word. It should not be sold under the name of butter, but under a particular designation, which will permit it to be distinguished from butter so called or true milk butter.

The unqualified approval of Mége's margarine by the Council of Health was impugned by a commission of the Academy of Medicine for the Prefect of the Seine. The commission disapproved of the article for use except to a limited extent in cooking on the ground of its comparative indigestibility. ${ }^{1}$

The Mége process was patented in England in I869, and in the United States in I873. ${ }^{2}$ In IS7I, however, a Mr. Bradley patented in the United States a process for manufacturing butter which was to answer the purpose of lard, butter, or cream for culinary and other uses. ${ }^{3}$ The same year the Mége process was patented in the United States a M.Ir. Paraf organized in New York City the Oleo-Margarin

\footnotetext{
'Second Anmul Report of the New York State Dairy Commissioner, p. 377.

${ }^{2}$ Report of the U.S. Internal Revenue Commissioner for 1887 , p. cli.

3 Letters-Patent No, I10,626, dated Jan. 3, I871. From Second Anmual Report of New York State Dairy Commissioner, p. 327.
} 
Manufacturing Company which began the manufacture of "oleo-margarin ". According to the census there were I 5 establishments manufacturing the product in the United States in I880. In 1890 there were only 12 . The decrease was partly due to the federal law passed in I 886 which required that a tax be paid on the quantity produced and that a special annual tax be paid by the manufacturer and dealer. This probably had the effect of causing some producers to close their factories. ${ }^{2}$ By 1900 , there were 24 establishments, and in I9I4 there were $30 .^{3}$

The manufacture of oleomargarine spread all over Europe, including Russia. Its production created one of the most difficult social problems that society has ever been called upon to regulate. European countries as well as the United States enacted either special laws relating to oleomargarine or general food laws under which the oleomargarine frauds could be prosecuted. ${ }^{4}$

\section{MANUFACTURE OF OLEOMARGARINE ${ }^{5}$}

Since M. Mége first manufactured oleomargarine many variations in the process have been worked out. The only fat constituent other than that contained in the milk that he used was the oleo oil rendered from beef tissue. In the oleomargarine now made oleo oil forms a much smaller part of the product. Neutral lard is added in large quantities and in the cheaper grades more cotton-seed oil is added

${ }^{1}$ First Anmual Report of the Pennsylvania Board of Agriculture, 1878, p. 200.

${ }^{2}$ The Census Bureau is not sure that the statistics for oleomargarine were separately reported in all cases.

'Report of U. S. Internal Revenue Commissioner for I9I4, p. 209.

-Vide, Report of U. S. Internal Revenue Commissioner for I888, p. clxxxviii.

${ }^{5}$ Vide, Census 1900, vol. ix, pp. 521-4. 
than neutral lard. In the best grades some butter enters into the product while in the cheapest grades the mass is churned with milk, skim milk, or butter milk. Oleo oil and neutral lard are chiefly manufactured by the packers, some of which they use in their own oleomargarine manufacture. Large quantities of these products are sold to establishments exclusively engaged in the manufacture of oleomargarine. Oleo oil is also made in cities over the country from fat collected from retail butchers. When the market for oleomargarine is unfavorable much of the oleo oil is used in the manufacture of other food products.

Oleo oil is obtained from beef fat through the successive steps of heating, settling, crystallization, and pressure by which it is separated from the stearin and the fiber. In the packing houses immediately after the slaughter of the animal the fat is removed and thoroughly washed in warm water, after which it is chilled and hardened with ice water. It is then minced finely with cutting machines, heated to a temperature of 160 degrees $F$., agitated until the whole mass is melted and then allowed to settle. Settling is accelerated by spreading salt over the surface. After all the fiber and scrap have settled to the bottom the clear oil is siphoned into another vessel, where salt is again added and the temperature controlled to allow further settling. After sufficient settling has taken place it is siploned into a vat where it stands from three to five days. During this time the stearin in the oil crystallizes. Part of it forms a crust over the surface and part falls to the bottom. The whole mass is then agitated until it is mushy, after which it is wrapped in canvas cloths and gradually subjected to hydraulic pressure. The oil is forced out and the stearin, which is the hard substance in fats and is most prominent in mutton tallow, remains in the canvas cloths. The oleo oil is then ready for use. It can be piped to the oleomar- 
garine department or be allowed to harden for shipment to points where manufacturers of oleomargarine do not prepare their own oleo oil.

Neutral lard is the deodorized fat of the hog. There are two principal grades of neutral lard. The best grade is made from the leaf fat which is the fat taken from the side of the hog. This is of much better quality because it has less of the lard flavor and can be more completely netitralized than the fat from the back part of the hog. The second grade of neutral lard is made from the back fat. Lard is neutralized by the pachers or is bought from them and is neutralized by near-by manufacturers, who prefer to deodorize or neutralize their own fat. The neutralization of lard is simpler than the process of making oleo oil. At the packing houses, immediately after the killing of the animal the leaf fat is removed and hung up in the refrigerating room to rid it of the animal heat as soon as possible. It is then rendered at a low temperature and allowed to settle. Salt is added as in the case of the settling process of the beef oil. The clear oil is siphoned to another vessel for further settling. In a more extended treatment the temperature is controlled until settling has been repeated a number of times. After sufficient settling has taken place the neutral lard is ready for use.

Cottonseed oil is used in the cheaper grades of oleomargarine. It is not used in the better grades because it cannot be neutralized and because its use is betrayed by its characteristic flavor in oleomargarine. It must also be used in limited quantities, because its melting point is low. Too large quantities make the product softer than butter. The amount of cottonseed oil can be increased if more stearin is added to harden the mixture. Glycerine is added sometimes to give a glossy appearance; and sugar or glucose is added sometimes to sweeten it or to give the desired texture. 
In establishments that make their own oleo oil and neutral lard these constituents are piped to the room where the oleomargarine is made and there mixed while they are still in the liquid state. Establishments that buy their oleo oil or neutral lard are fitted out with separate tanks in which the constituents are melted. If butter enters into the compound a tank must be provided to melt butter. All the constituents are weighed according to a formula of the manufacturer's own or as called for by dealers. The mixture is rapidly cooled to prevent crystallization. After it is cooled it is tempered, churned with milk or cream, salted, and worked. Many different grades can be produced because the proportion of the constituents can be easily varied and because the quality of the constituents themselves may vary greatly. Following are formulas ${ }^{1}$ of three different grades:

Formula I.-Cheap Grade

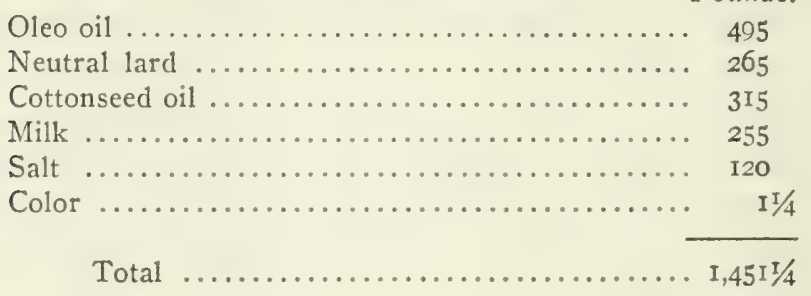

This will produce from $I, 265$ to 1,300 pounds of oleomargarine.

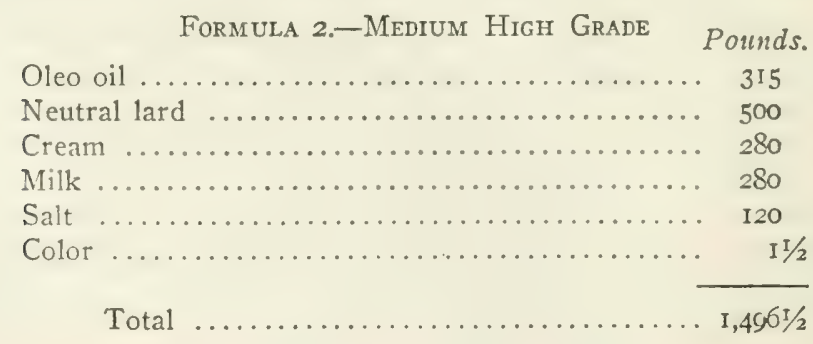

${ }^{1}$ From Census 1900, vol. ix, p. 521 . 
This will produce from I,O5O to I,OSo pounds of oleomargarine.

\section{Formula 3.-High Grade}

\begin{tabular}{|c|c|}
\hline \multicolumn{2}{|r|}{ Pounds. } \\
\hline Oleo oil & 100 \\
\hline Neutral lard & I3O \\
\hline Butter ....... & 95 \\
\hline Salt. & 32 \\
\hline Color & $1 / 2$ \\
\hline
\end{tabular}

This will produce about 352 pounds of oleomargarine.

Table no. 24 shows the distribution of the production of

TABLE XXIV

Estimated Pronuction of Oleomargarine in Eurupean Countries

\begin{tabular}{|c|c|c|}
\hline & Quantity produced & Quantity imported \\
\hline & Pounds & Pounds \\
\hline United Kingdom............... & $82,000,000$ & $110,000,000$ \\
\hline 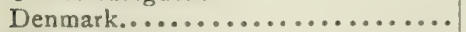 & $35,000,000$ & $4,500,000$ \\
\hline 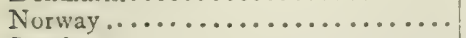 & $22,000,000$ & .................. \\
\hline Sweden........................ & $22, \mathrm{cco}, \mathrm{OCO}$ & . $\ldots \ldots \ldots \ldots \ldots \ldots$ \\
\hline Germany.................... & $220,000,0 \mathrm{co}$ & $\ldots \ldots \ldots \ldots \ldots \ldots$ \\
\hline Netherlands $\ldots \ldots \ldots \ldots \ldots \ldots \ldots$ & $123,000,000$ & ............... \\
\hline Belgium...$\ldots \ldots \ldots \ldots \ldots \ldots \ldots$ & $20,000,000$ & ................. \\
\hline
\end{tabular}

(From U. S. Census Igco, vol. 9, p. 520.)

oleomargarine by countries. The United States produced over I07 million pounds in I900. This country was therefore third in the production of oleomargarine in 1900 .

The distribution of the manufacture and trade in the United States is shown in table no. 25. 


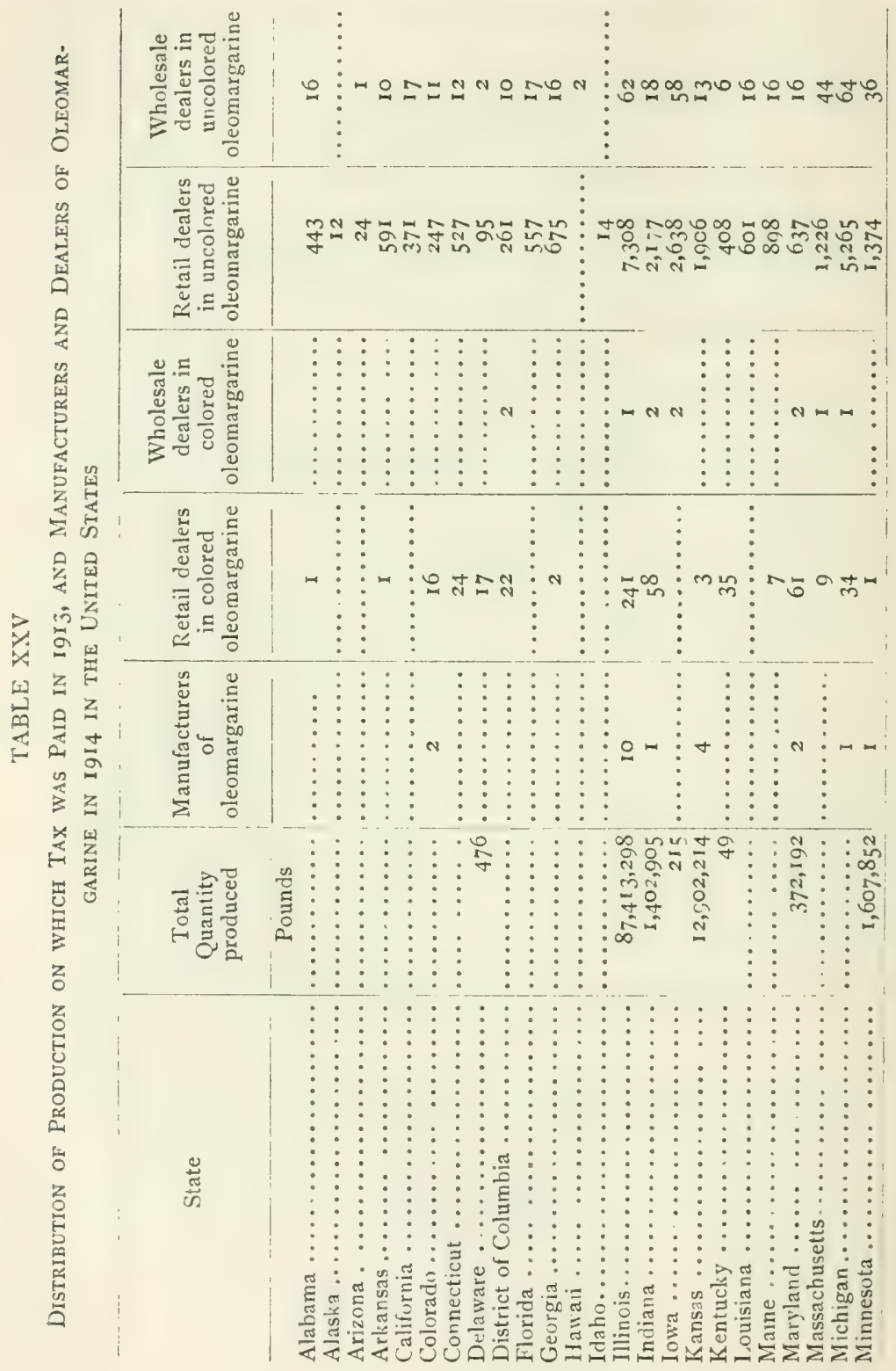




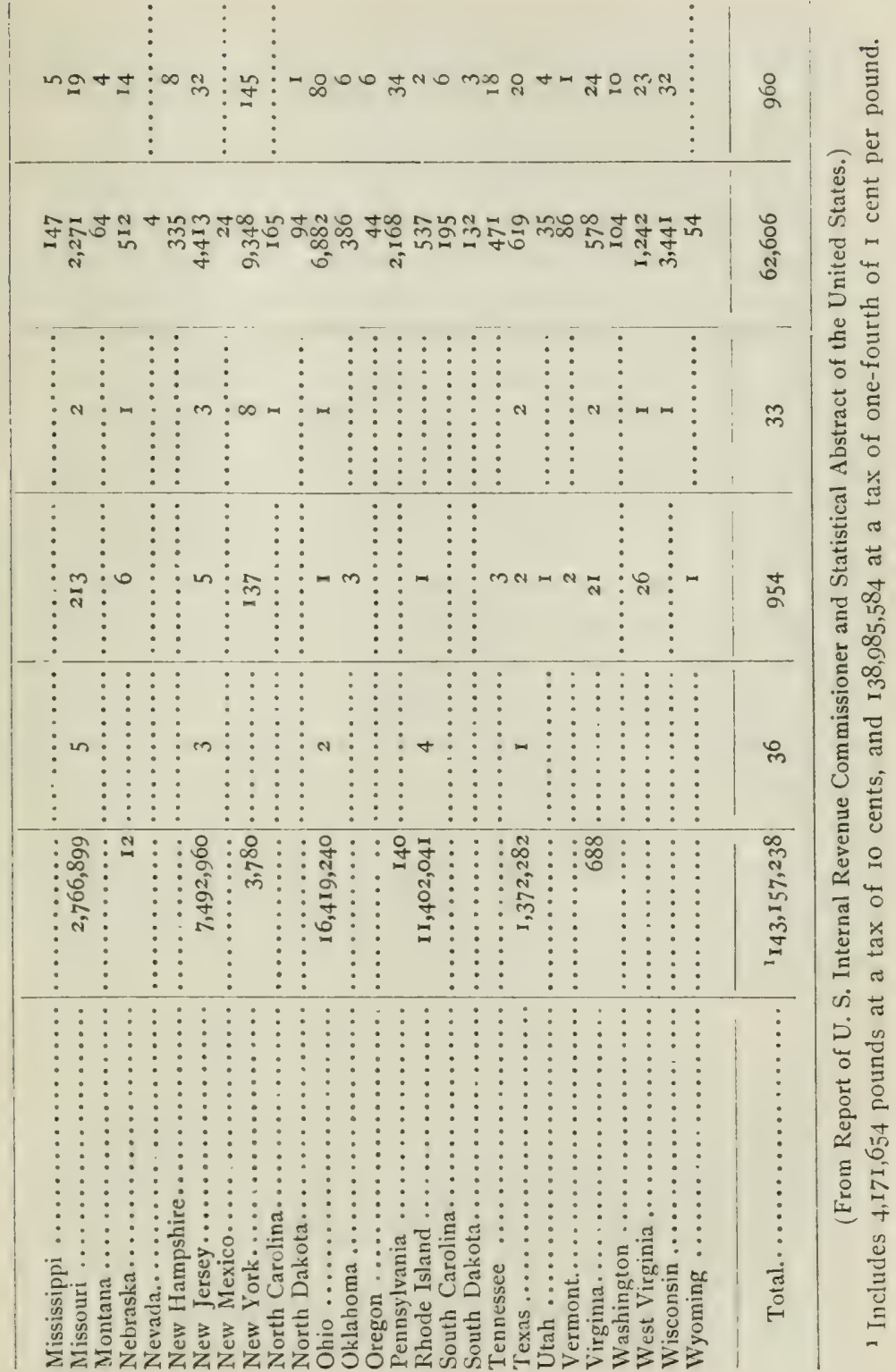


Table no. 25 shows that more than half of the total amount of oleomargarine is produced in Illinois. Ohio is second; Kansas, third, and Rhode Island fourth. The greater part is of course produced by the packers. The greatest number of retail dealers are found in New York state, showing that this state consumes a large amount of oleomargarine. Illinois, Ohio, Michigan, New Jersey, and Wisconsin also have a great many retail dealers that sell oleomargarine and some of these are pronounced dairy states. According to a statement ${ }^{1}$ prepared by the U. S. Treasury Department the amount of oleomargarine shipped into the various states during the fiscal year ending June 30, I 899 , shows that Illinois received I $8,638,902$ pounds; Pennsylvania, I I,433,34I pounds; Ohio, 8,830,969 pounds; and New Jersey, 5, 875,975 pounds. Indiana, Rhode Island, Missouri, Michigan, and Massachusetts also received from two to three million pounds each. The records indicate that most of the oleomargarine is consumed in parts of the country well provided with transportation facilities and that it is not principally consumed by "lumber jacks" or in frontier regions. Oleomargarine is a food product that is apparently steadily gaining favor with the masses everywhere. In 1887 , over $21,000,000$ pounds was produced in the United States, and by I9I4 the amount produced exceeded $14 \mathrm{r}, 000,000$ pounds. ${ }^{1}$

\section{WHOLESOMENESS OF OLEOMARGARINE}

Mége's process made use of carbonate of potash in rendering oleo oil, and later American patents also used at various stages in the manufacture in the oleomargarine such acids as sulphuric, nitric, benzoic, salicylic, etc., and such

1 Senate Report no. 2043, 56th Congress, 2d session, p. 90.

'Report of the U.S. Internal Revenue Commissioner. 
alkalies as caustic soda, bicarbonate of soda, carbonate of ammonia, ctc. ${ }^{1}$ When the manufacture of oleomargarine was first begun, not only were there probably injurious chemicals used in the deodorizing processes but oils were used that were unfit for food. This statement ${ }^{2}$ was positively made by Mr. Beran to Dr. E. H. Bartley. Mr. Beran who had the contract for removing dead animals in Drooklyn made oil from the top parts of horses' necks. Some of these horses died of disease, others from accidents. Some of the oil it was stated was sold to establishments making oleomargarine. Before the New York Committee on Public Health ${ }^{3}$ the charge that fats from diseased animals were used in the manufacture of oleomargarine was very strenuously denied by the manufacturers who claimed that a tainted smell could not be removed by the deodorizing process. Whatever may have been the practice in the early history of oleomargarine manufacture, since the enactment of the federal law of I886, deleterious ingredients have not been used. Section I4 of this act requires the Internal Revenue Commissioner to make analyses of olcomargarine and ascertain whether its ingredients are wholesome. The Commissioner of $\mathrm{I} 887$ states in his report that manufacturers " are earnestly endeavoring to render their product not deleterious to the public health ". Concerning the comparative digestibility of fats, Prof. Henry C. Sherman says the following: ${ }^{6}$

Concerning the comparative digestibility of fats, Prof.

${ }^{1}$ Second Annual Report of the New York State Dairy Commissioner, p. 386.

${ }^{3}$ Idem, p. 385 .

${ }^{3}$ N. Y. Sen. Com. on Pub. Health, p. 91 .

${ }^{4}$ Report, p. cxl.

B Food Products, p. 389. 
greatly in the extent to which they are absorbed from the digestive tract under normal conditions. Such differences as have been found seem to be explained by the differing hardness or melting points of the fats. If the melting point of the fat lies much above the body temperature, the fat will not become sufficiently fluid in the intestine to be readily emulsified and digested. The following data determined by Munk and Arnschink are cited by Von Noorden in this connection:

\begin{tabular}{|c|c|c|}
\hline Nature of fat & Melting Point C. & Per cent lost in feces \\
\hline 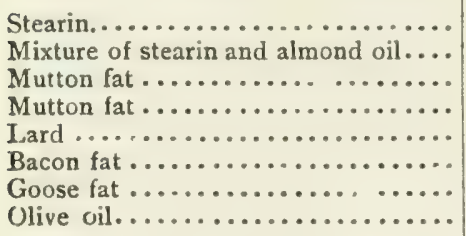 & $\begin{array}{c}60 \\
55 \\
50-51 \\
49 \\
43 \\
34 \\
25 \\
\text { fluid }\end{array}$ & $\begin{array}{c}86-91 \\
10.6 \\
9.2 \\
7.4 \\
2.6 \\
2.8 \\
2.5 \\
2.3\end{array}$ \\
\hline
\end{tabular}

These results show good utilization and no significant differences in digestibility among fats melting at or below 43 degrees C. while with melting points from 49 degrees to 55 degrees $\mathrm{C}$. the losses were considerable, and with stearin melting at 60 degrees $C$. much the greatest part failed of digestion. Notice, however, that the admixture of sufficient almond oil to lower the melting point a few degrees resulted in very greatly increased digestibility. Hence while stearin eaten alone is only slightly digested, yet fats containing much stearin may be digested very well provided they also contain enough olein so that the melting point of the mixture as a whole is not much above body temperature. Since oleomargarine contains notably more stearin than butter it was at one time thought that it might show correspondingly larger losses in digestion; but repeated experiments have shown that oleomargarine (being made so as to have the same hardness) shows practically the same losses in digestion as does butter. Thus in experiments 
by Luhrig the coefficient of digestibility was 97.86 per cent for the butter and 97.55 for the oleomargarine.

Following is the composition of oleomargarine as stated by Dr. Harvey W. Wiley, ${ }^{1}$ and his comment concerning its wholesomeness :

$\begin{array}{cccccc}\text { Water } & \begin{array}{c}\text { Insoluble } \\ \text { acid }\end{array} & \begin{array}{c}\text { Soluble acid by } \\ \text { washing out }\end{array} & \begin{array}{c}\text { Soluble acid by } \\ \text { distillation }\end{array} & \text { Salt } & \text { Albuminoids } \\ 9.34 & 93.59 & 0.12 & 0.25 & 3.64 & 0.35\end{array}$

From the above data it is seen that the objections to the use of oleomargarine are more on the grounds of fraud and deception than in regard to nutritive and dietetic value. The components used in the manufacture of oleomargarine, when properly made, are all wholesome and digestible materials such as are consumed in eating various food products. It does not appear therefore, that any valid objection can be made against the use of oleomargarine from a physiological or hygienic standpoint.

Many eminent chemists and physiologists ${ }^{2}$ long ago attested to the wholesomeness of oleomargarine when it is made from carefully selected fats and when its process of manufacture is clean and does not include the use of deleterious chemicals.

\section{RENOVATED AND ADULTERATED BUTTER}

Reference has been made in previous chapters to renovating butter and also to the adulteration of butter with water. Rancid butter is melted at a low temperature, the froth or scum is removed, and the curd and brine which settle out of the melted butter are drawn off : faulty odors are expelled by blowing air through the melted fat, and the

\section{${ }^{1}$ Foods and Their Adulteration, p. I9o.}

${ }^{2}$ Vide, Report of U. S. Internal Revenue Commissioner for 1887 , p. clii. 
butter oil is then re-churned with fresh milk or cream to give it a fresh butter flavor. ${ }^{1}$ This is "renovating" or "processing" butter. Numerous processes for removing the rancidity from butter were tried and some were successfully used some time before I886. The early methods consisted in washing the butter with water alone, or with water containing minute amounts of alkali. ${ }^{2}$ In the chapter dealing with the grading of butter it was seen that as early as I 886 renovated or process butter was officially included among the classes of butter by the New York Mercantile Exchange, and that they defined renovated butter as butter made by melting, ctc. In the administration of the oleomargarine law the U. S. Internal Revenue Commissioner encountered many samples of renovated butter during the year, $1887 .{ }^{3}$ Analyses showed that chemicals were used to destroy the rancidity of old butter. Major Henry E. Alvord of the U. S. Department of Agriculture called attention to the enormous manufacture and sale of renovated butter in 1898 before the National Association of the State Dairy and Food Departments held in Harrisburg, Pa. Few, if any, state laws at that time covered renovated butter. The Dairy and Food Commissioner of Michigan, in his report of I879, says, "One can scarcely conceive how the illmade and spoiled country butters, after lying for weeks in the hot store rooms of country merchants and becoming positively nauseating, can be worked over and made sufficiently deceiving as to be sold for creamery butter. The fact remains that this is done. and in Michigan at least tons of this worked over, renovated butter is annually sold under

2 H. C. Sherman, Food Products, p. 377.

- Annual Report of the New York State Dairy Commissioner for r886, p. I8I.

Report of Internal Revenue Commissioner for 1887 , p. cxlii. 
misrepresentation or greater or less deceit." 1 Congress first legislated on renovated butter in 1902.

The usual method for adulterating butter is by the addition of too much water, although lard, or other foreign fats and corn starch have also been used. In the Act of Congress of May 9, 1902, adulterated butter and renovated or process butter are defined as follows:

That "adulterated butter" is hereby defined to mean a grade of butter produced by mixing, reworking, rechurning in milk or cream, refining, or in any way producing a uniform, purified or improved product from different lots or parcels of melted or unmelted butter or butter fat, in which any acid, alkali, chemical, or any substance whatever is introduced or used for the purpose or with the effect of deodorizing or removing therefrom rancidity, or any butter or butter fat with which there is mixed any substance foreign to butter as herein defined, with intent or effect of cheapening in cost the product or any butter in the manufacture or manipulation of which any process or material is used with intent or effect of causing the absorption of abnormal quantities of water, milk, or cream; that "process butter" or "renovated butter" is hereby defined to mean butter which has been subjected to any process by which it is melted, clarified, or refined, and made to resemble genuine butter, always excepting "adulterated butter" as defined by this Act.

As defined in this Act, renovated butter is butter made through the usual renovating process, but without the use of any acid, alkali, chemical or any substance whatever. If these substances are employed in the renovating process the product is classed as adulterated butter. If butter, renovated butter included, contains abnormal quantities of moisture it is also classed as adulterated butter. The Act of 1902

1 Pages 20-I. 
requires the Secretary of Agriculture to prescribe rules and regulations to carry out the provisions of the Act relating to renovated and adulterated butter. Abnormal quantities of water the Secretary held to be water in excess of 16 per cent. It is held that normal butter contains from I 2 to I4 per cent of water.

The provisions of the federal law as regards adulterated butter are very stringent. The manufacturer of adulterated butter must pay a special tax of $\$ 600$ per annum, and wholesale and retail dealers, $\$ 480$ and $\$ 48$ respectively. In addition to the special taxes a tax of ro cents per pound is imposed on adulterated butter. The manufacturer of renovated butter must pay a special annual tax of $\$ 50$. Wholesale and retail dealers in renovated butter do not pay any taxes, nor is there a tax imposed on the product. The Secretary of Agriculture is charged with the inspection of renovating factories and storehouses where "renovated butter is manufactured, packed and prepared for the market and of the products thereof and materials going into the manufacture of the same". The Secretary shall also have power to ascertain whether or not materials used in the manufacturing process are deleterious to health. If he finds that the finished product, whether for exportation or for shipment into other states, is unwholesome, he is directed to confiscate it. All renovated or adulterated butter must be plainly marked as prescribed by the Secretary. There is therefore very strict supervision of the renovating process, and the result has been that during the last decade an annual saving of about 40 million pounds of butter has been added to our butter supply. Most of this butter would have been absolutely worthless as food, if it had not been subjected to the renovating process; and if it had been renovated without government supervision, it would have been manufactured from butter that was no longer fit for human food 
and deleterious chemicals would have been used to deodorize it.

In view of the keen competition among creameries they endeavor to swell their profits by increasing the over-run. This matter is discussed in the chapter dealing with the manufacture of butter. Frequently the over-run is increased so as to include more than 16 per cent of water. This of course causes it to fall within the class of adulterated butter. In the administration of the tax provisions the Commissioner of Internal Revenue ${ }^{1}$ finds that the creameryman in many cases is unnecessarily burdened by the imposition of the $\$ 600$ annual tax. He also states that dealers are frequently unvittingly involved and that the tax of $\$ 480$ for wholesale dealers and $\$ 48$ for retail dealers operates with too much severity. The Commissioner suggests that the manufacturer be made to pay only $\$ 60$ as an annual tax, and be fined or imprisoned for each specific violation of the law. This is the usual method for punishing crime and seems to be the most effective way. Besides, it punishes a specific act and does not require the collection of a burdensome annual tax.

The Commissioner also points out that the legal standard for unadulterated butter should not be based on moisture content but on fat content. He says that "a sample of butter may show 78 per cent of butter fat, 6 per cent curd, I per cent solids (salt), and only I 5 per cent moisture, and be therefore legal butter; whereas another sample may show $8_{3}$ per cent butter fat, no curd, one-half of I per cent solids (salt), and $161 / 2$ per cent moisture, and while a greatly better butter because butter fat is what the consumer desires to buy, is nevertheless adulterated under the law". The water content is obviously a very poor basis

${ }^{1}$ Report for IOII, p. 20. 
as a legal standard for good butter. Some of the states have adopted the federal rulings as to a butter standard, but most of them have adopted a standard of fat content. The percentage of fat required by the various states ranges from 80 to $83 .{ }^{1}$ The District of Columbia requires 83 per cent of fat in butter, thirteen states require 82.5 per cent, and eight require 80 per cent.

\section{THE MOVEMENT FOR OLEOMARGARINE LEGISLATION}

The first oleomargarine factory in America seems to have been established in New York City in I873. The product began to appear upon the market in large quantities a few years later. All dairymen and farmers over the country soon became thoroughly aroused and organized a vigorous movement that had for its object legislation that would preserve their industry from the ruinous onslaughts of oleomargarine production. The effect of the rapid introduction of olecmargarine was most harmful to the dairymen and creamerymen. The product displaced butter on the market because it could be sold for much less. A great many retailers dealt in oleomargarine because the chances for profits were greater than in butter. It was testified before the New York Senate Committee on Public Health, ${ }^{2}$ which investigated oleomargarine frauds in $188_{4}$, that some men were " retailing oleomargarine at twenty cents per pound, cthers are charging as high as thirty cents: and still others tell me that they are selling butterine at thirty cents, thirtyfive cents, and even forty-five cents, all out of the same tub". Before the same Committee, commission men of New York City testified that 75 per cent of the wholesale dealers dealt in olecmargarine, but that there was a ten-

${ }^{1}$ Vide, table in Agricultural Yearbook for 19r3, p. 487.

${ }^{3}$ Report, p. 103. 
dency for oleomargarine manufacturers to deal directly with the retailers and thus hurt their entire trade. ${ }^{1}$ It was the producer of butter fat and the manufacturer of butter that most severely felt the introduction of oleomargarine. Greater quantities of the cheaper grades of butter were on the market then, than now, and these cheap grades of butter were in direct competition with oleomargarine. Good oleomargarine is of course much better than poor butter. At times when prices of the best butter are unusually high, oleomargarine also displaces good butter, or at least has the effect of lowering high prices. It was to be expected, therefore, that the movement seeking suppressive oleomargarine legislation was organized by the class of property holders or business men that suffered most through the unbridled production of oleomargarine. This class was the dairy farmer.

Most laws are an expression of the economic motive of certain groups of society. These groups, whose income is at stake, take the initiative in creating a public sentiment, favorable to their cause, and bring direct pressure upon legislators. The consumer is usually unorganized, but when there is a strong organization to lead the movement, he is ready to take sides. In the movement leading up to oleomargarine legislation the aid of the consumer was easily enlisted because he was daily defrauded and was made to believe that he was endangering his health. The aid of the sympathetic social reformer was also readily secured through the spread of stories of wholesale adulteration and the use of deleterious chemicals. Geo. F. Angell, President of the Massachusetts Society for the Prevention of Cruelty to Animals, Vice-President of the American Humane Association, and Director of American Social Science Associa-

1 Report, op. cit., p. 123. 
tion, addressed the Boston Board of Trade on November II, I880, as follows:

A single firm in New York City has recently contracted with parties in Vermont for 300,000 firkins to be delivered this year, for packing oleomargarine butter.

It is not only filling our markets in the shape of butter, but also as cheese. Many creameries and many large dairies as I am informed, are now mixing twenty-five per cent or more of oleomargarine oil with their cheese.

In view of the great and increasing magnitude of this business and the danger of using the raw fats and stomachs of diseased animals, and of those that die on the cars which number hundreds of thousands annually, and of those that die of pleuro-pneumonia, or cattle fever, or hog cholera, I think we have no reason to rejoice over the erection of these enormous factories which are now supplying the tables of our hotels, restaurants, boarding houses, and private families with oleomargarine, butter and cheese. ${ }^{1}$

There were probably numerous other humanitarians of this type that were interested in the movement purely from the point of view of social betterment. The force behind the movement, however, was the dairyman. He had the organization, and the votes to elect state and national senators and representatives. In this connection Prof. H. C. Adams, in his report as Dairy and Food Commissioner of Wisconsin, says :

When the American farmer is roused he keeps everybody busy. He may be childish sometimes, but nobody accuses him of being weak when he stirs his class to action in a movement that is right. The American farmer can get along without flattery. He ought not to get along without justice. He

1 Reprinted in Transactions of Illinois Department of Agriculture for I880, p. 353 . 
sometimes nods and sleeps over public questions but when he goes at it in earnest, to take a hand in their settlement, political rings are broken, unwise political bosses go up in the air, golden collars become a rope of sand and popular judgment is crystallized into law. ${ }^{1}$

The fight was waged through dairy associations, the Farmers' Alliance, or Grange, and other agricultural organizations. Many resolutions were adopted at conventions held by these organizations denouncing the oleomargarine traffic and calling upon legislators to protect the dairy industry.

The first state laws attempting to deal with oleomargarine were enacted in New York and Pennsylvania in I877. Maryland followed with a law in 1878. In New York the dairymen were not only responsible for the law of 1877 , but for subsequent laws passed in I880, I882, and in $1884 .^{2}$ The laws passed prior to 1884 remained unenforced because there was no effective executive machinery provided for. This was, however, established in 1884 .

Before the first oleomargarine law was passed in Pennsylvania, the bill was submitted for approval to the Solebury Farmers' Club, to the Bucks County Agricultural Society, and to the Doylestown Agricultural and Mechanics Institute. ${ }^{3}$

The President of the Illinois Dairymen's Association in I 880 asked the convention to take measures that would provoke legal enactments against the wholesale adulteration of foods. His appeal included the consumer as well as the dairymen: "The time has come when the people, yea, the

${ }^{1}$ Report of Dairy and Food Commissioner of Wisconsin for 1902, p. 60 .

${ }^{2}$ Vide, Investigation of N.Y. Senate Committee on Public Health, p. 2 .

3 First Annual Report of the Pennsylvania Board of Agriculture, I878, p. 201. 
whole people of our country should rise in their might and proclaim their determination to have some important change brought about on this subject.". ${ }^{1}$ The convention responded by instructing its legislative committee to take prompt action.

The IVisconsin Dairymen's Association 2 adopted the following resolution in $\mathrm{I} 88 \mathrm{I}$ :

The dairy interest of Wisconsin has become the leading branch of farm production, and this great interest is seriously menaced, and in danger of being ruined by the manufacture of large quantities of oleomargarine, sueine and other adulterations disguised to take the place of genuine butter, which find their way into the general market and are placed before the consumer as pure butter, greatly to the injury of the butter makers of the state, therefore,

Resolved, That in view of these facts and their bearing on the great interests we represent, this Association most earnestly requests at the hands of the present legislature, the passage of a law, etc.

Among other resolutions the Michigan State Dairy Association adopted the following:

Resolved, That the Michigan State Dairy Association emphatically demand the passage of a law compelling dealers to give with every purchase of imitation butter a written or printed notice that the product sold is a substitute for butter or an imitation of it.

Other state dairy associations were also active. Enough has been cited to show that the real force behind the movement was the dairy farmer through his dairy association. Not only did the farmer work for state dairy laws but for

${ }^{1}$ Report of Illinois Dairymen's Association for 1880, p. 348.

${ }^{2}$ Report for 1881 , p. 130. 
the federal law as well. A portion of the Report of the House Committee on Agriculture says, "That there are from four to five million American citizens engaged in the dairy business and that they must all abandon it and be driven into some other already overworked branch of industry unless they can be relieved from the present ruinous competition with cheap imitations of butter and cheese ". When the law of I 886 was to be amended in 1902 dairy associations again became active. ${ }^{2}$

This was mainly a fight between economic intereststhe dairymen on one side and the oleomargarine interests and stockmen on the other. The arguments the oleomargarine interests raised were that the product was a boon to the poor people who could not pay the price of butter, that large quantities of cottonseed oil were consumed in the manufacture of oleomargarine, and that large amounts of the country's capital were invested in oleomargarine establishments. These arguments were presented to enlist various classes to aid them in their fight with the dairymen.

The laws themselves show very little of the nature of this movement. Some of the early laws, however, reflect it in their titles. For instance, the title of the first New York law reads: "An Act for the protection of dairymen and to prevent the deception in sales of butter". The title of the Maryland law of 1878 is similar.

Very little also can be learned as to the nature and origin of the movement for oleomargarine legislation from the opinions of the Supreme Court deciding upon the ultimate validity of these laws. The logic and reasoning of the court rather tend to center one's attention upon abstract ethical

${ }^{1}$ Report of the U. S. Internal Revenue Commissioner for I887, p. cxxxi.

${ }^{2}$ Vide, for instance, Michiga: Dairy Association Report for Igor, p. 108 . 
principles and legal technicalities. In most cases opinions deal with fraud, public health, public policy, and the relation of the oleomargarine law to the interstate commerce clause. However, in the case of Plumley $v$. Mass., I $55 \mathrm{U}$. S., 475, the economic interests behind the movement are plainly visible. In this case Justice Harlan quotes from the opinion in People $\%$ Arenburg, I05 N. Y., I23, in language as follows:

Assuming, as is claimed, that butter made from animal fat or oil is as wholesome, nutritious, and suitable for food as dairy butter; that it is composed of the same elements and is essentially the same article, except as regards its origin, and that it is cheaper; and that it would be a violation of the constitutional rights and liberties of the people to prohibit them from manufacturing or dealing in it, for the mere purpose of protecting the producers of dairy butter against competition, yet it cannot be claimed that the producers of butter, made from animal fat, or oils, have any constitutional right to resort to devices for the purpose of making their product resemble in appearance the more expensive article known as dairy butter, or that it is beyond the power of the legislature to enact such laws as they may deem necessary to prevent the simulated article being put upon the market in such a form and manner as to be calculated to deceive.

There is much justification for the dairy laws that have been enacted. Fraud must be prevented. The consumer must be enabled to choose between butter and oleomargarine. The public health must be protected. The use of all deleterious ingredients in the manufacture of oleomargarine must be prohibited. Oleomargarine must be sold upon its merits, and to this extent the dairy interests of the country have every right to demand and to receive protection. 


\section{CHAPTER X}

The Oleomargarine Law and Its Development

SUMMARY OF DEVELOPMENT

THE state and federal oleomargarine laws are an evolutionary product. The first state laws passed between 1877 and 1884 were inoperative because the necessary machinery to enforce them was lacking. In 1884 the state of New York ${ }^{x}$ created the office of Dairy Commissioner, whose special duty it was to ferret out violations of the law and to prosecute offenders. This was a very important innovation in the dairy and food legislation of the United States. It had the effect of enforcing not only the provisions of the law pertaining to oleomargarine, but also those pertaining to milk and other dairy and food products. Other states followed in the establishment of the office of dairy and food commissioner.

The general principle upon which all of the early state laws were based was restrictive; that is, it restricted the manufacture and sale of oleomargarine to a product which contained no coloring matter and required that it be marked or branded so as to inform the purchaser of its real character. ${ }^{2}$

Then came the period of prohibitory laws. These

${ }^{1}$ Laws of N. Y., I884, p. 255.

${ }^{2}$ Vide Laws of New York, I882, Chap. 238; laws of Pennsylvania, I $878, \mathrm{p} .87$.

$465]$ 
prohibited the manufacture and sale of oleomargarine in any form whatsoever. This principle was resorted to because the states were unable to cope with the oleomargarine frauds. The New York legislature, for instance, in I884, authorized the Senate Committee on Public Health to make a thorough investigation of the oleomargarine trade and to make such recommendations as it might deem proper. The committee went into the question of drafting a more stringent law than was in effect at that time. The state of Missouri had already enacted a prohibitory law ${ }^{\mathrm{I}}$ whose constitutionality and validity had been upheld in a decision of the Circuit Court of Missouri. ${ }^{2}$ The New York Senate Committee, therefore, conciuded that a prohibitory law, together with the establishment of effective executive machinery, would best meet the needs of the exigency in their state. The New York law of $1884^{3}$ accordingly embodied the prohibitory principle, which, however, was declared unconstitutional by the Court of Appeals in the case of People $v$. Marx, 99 N. Y. 377. Pennsylvania made its law prohibitory in $1885 .{ }^{4}$ Maine, Michigan, Minnesota, and Wisconsin also enacted prohibitory laws. Some states carried the principle of restriction to such an extreme that in its application it was prohibitory. New Hampshire, Vermont, and South Dakota, for instance, passed laws requiring that oleomargarine be colored pink. ${ }^{5}$ The constitutionality of the prohibitory

${ }^{1}$ March 24, 188I.

${ }^{2}$ In re Brosnahan, Jr, , I8 Fed. Rep. 62.

${ }^{3}$ Laws of N. Y., I884, p. 255.

${ }^{4}$ Laws of $\mathrm{Pa} .$, I885, p. 22.

${ }^{5}$ Vide résumé of state laws in Report of N. Y. State Dairy Commissioner for 1886, p. 4I0; and report of Wisconsin Dairy and Food Commissioner for 1898 , p. 204 . 
principle was upheld by the U. S. Supreme Court in the case of Powell $v$. Pennsylvania (127 U. S. 678).

Just as the prohibitory principle became firmly rooted in the state laws, Congress enacted a law (August 2, I886) imposing a tax of two cents per pound on oleomargarine, and special annual taxes of $\$ 600, \$ 480$, and $\$ 48$ on manufacturers, wholesale dealers, and retail dealers, respectively. This act made the prohibitory principle embodied in the oleomargarine law of many states unconstitutional. The fact that the United States government imposed an internal revenue tax on oleomargarine caused the courts to hold that Congress recognized the product as a lawful article of commerce. Laws of states, therefore, prohibiting the admission of oleomargarine into their territory were in conflict with the constitutional interstate commerce clause. The prohibitory principle which had been upheld by the U. S. Supreme Court in the case of Powell $v$. Pennsylvania was now declared unconstitutional in the case of Schollenberger $v$. Pennsylvania (I 7 I U. S. I) decided May $23,1898$.

The decision of the U. S. Supreme Court swept the prohibitory principle off the statute books and forced a recession to the original restrictive principle. The restrictive principle was supplemented with rigorous administration, a system of license fees, and conspicuous branding or marking. For a more detailed view of the development of the oleomargarine law, a study of the successive changes made in the law of Pennsylvania will prove useful. Not only is the oleomargarine legislation of this state fairly typical, but two important cases that came up from the Pennsylvania courts and involved the constitutionality of the law were passed upon by the U.S. Supreme Court. These of course had an important 
influence upon the development of the oleomargarine law of the country.

RESTRICTIVE AND PROHIBITORY LAWS OF PENNSYLVANIA

The restrictive principle in the oleomargarine law of Pennsylvania, entitled "For the protection of dairymen and to prevent deception in sales of butter and cheese," and enacted in 1883 , allowed the manufacture and sale of oleomargarine, but required that all packages containing it should be branded or marked, and that retailers selling oleomargarine must give a printed label bearing the words "oleomargarine butter" to the purchaser. The law ${ }^{x}$ reads as follows:

Section I. Be it enacted, ... . . That every person who shall manufacture for sale, or who shall offer or expose for sale, or who shall export to a foreign country, by the tub, firkin, box or package, or any greater quantity, any article or substance in semblance of butter or cheese, not the legitimate product of the dairy, and not made exclusively from milk or cream, but into which any oil, lard or fat not produced from milk or cream, enters as a component part or into which melted butter or any oil thereof has been introduced to take the place of cream, shall distinctly and durably stamp, brand or mark upon the side of every cheese, and also upon the top and side of every such tub, firkin, box or package of such article or substance, the words "oleomargarine butter," or if containing cheese the words "imitation cheese" only, where it can be plainly seen in Roman letters, which shall be burned in or painted thereon with permanent black print in a straight line, and shall not be less than one-half inch in length, and if for export shall also invoice the same and clear the same through the custom house as "oleomargarine butter" or if cheese as "imitation cheese," and in case of retail sales of such articles

${ }^{1}$ Laws of Pennsylvania, 1883, p. 43. 
or substances in parcels, the seller shall, in all cases, sell or offer or expose the same for sale from the tub, firkin, box or package stamped, branded, or marked, as herein stated, and shall also deliver therewith to the purchaser, printed label having the plainly printed words "oleomargarine butter," ete.

In I885, the above law was repealed, and the manufacture and sale of oleomargarine were completely prohibited in the act ${ }^{x}$ entitled "For the protection of the public health, and to prevent adulteration of dairy products and fraud in the sale thereof." Section I. of this act is as follows :

Be it enacted, . . . . That no person, firm or corporate body shall manufacture out of any oleaginous substance or any compound of the same, other than that produced from unadulterated milk or of cream from the same, any article designed to take the place of butter or cheese produced from pure anadulterated milk, or cream from the same, or of any imitation, or adulterated butter or cheese, nor shall sell or offer for sale, or have in his, her or their possession with intent to sell the same as an article of food.

THE CASE OF POWELL $v$. PENNSYLVANIA

The validity of the Pennsylvania law of 1885 was tested in the case of Powell v. Pennsylvania (127 U. S. 678). The facts in the case are as follows: The defendant sold on July 10 , 1885 , in the city of Harrisburg, two original packages of butterine as such, and not as butter made from pure unadulterated milk or cream. The packages were marked "Oleomargarine Butter" as prescribed by the Pennsylvania statute. The defendant also had in his possession 100 pounds of the same article with intent to

\footnotetext{
${ }^{1}$ Laws of Pennsylvania, 1885, p. 22.
} 
sell it as an article of food. A verdict of guilty was returned by the Court of Quarter Sessions of the Peace in Dauphin County, Pennsylvania. The defendant was adjudged to pay a fine of one hundred dollars and costs of prosecution. The judgment was affirmed by the Supreme Court of the State, and the case was brought before the U. S. Supreme Court on a writ of error.

The defendant contended that the sale in question was not in violation of the laws of 1878 and 1883 , and that the law of 1885 upon which the prosecution was based, was in conflict with the Fourteenth Amendment of the Federal Constitution in that it denied to him equal protection guaranteed to others in the pursuit of an ordinary calling or trade; and this inequality deprived the defendant of his property without that compensation required by law.

Mr. Justice Harlan, who wrote the opinion of the Court, held that "the objection that the statute is repugnant to the clause of the Fourteenth Amendment forbidding denial by the State to any person within its jurisdiction of the equal protection of the laws, is untenable. The statute places under the same restrictions, and subjects to like penalties and burdens, all, who manufacture, or sell, or offer for sale, or keep in possession to sell, the articles embraced by its prohibitions; thus recognizing and preserving the principle of equality among those engaged in the same business."

The opinion further states that reference to the laws of 1878 and 1883 is irrelevant in as much as the prosecution is founded on the law of 1885 ; and that the question of regulation of the oleomargarine industry as provided for in the laws of 1878 and 1883 , or that of complete prohibition as provided for in the law of 1885 , is a matter of public policy, and is within the power of 
the state legislature to determine. Appeal can not be had to the judiciary but must be addressed to the state legislature through the ballot-box.

The opinion also holds that the Fourteenth Amendment was not designed to interfere with the exercise of the police power by the state for the protection of health, the prevention of fraud, and the preservation of public morals.

Upon these grounds the U. S. Supreme Court affirmed the judgment of the Supreme Court of Pennsylvania.

THE FEDERAL LAW OF I886.

The federal law defines butter and oleomargarine as follows :-

Sec. I. That for the purpose of this act the word "butter" shall be understood to mean the food product usually known as butter, and which is made exclusively from milk or cream, or both, with or without common salt, and with or without additional coloring matter.

Sec. II. That for the purposes of this act certain manufactured substances, certain extracts, and certain mixtures and compounds, including such mixtures and compounds with butter, shall be known and designated as "oleomargarine," namely: All substances heretofore known as oleomargarine, oleo, oleomargarine-oil, butterine, lardine, suine, and neutral; all mixtures and compounds of olecmargarine, oleo, oleomargarine-oil, butterine, lardine, suine, and neutral ; all lard extracts and tallow extracts; and all mixtures and compounds of tallow, beef-fat, suet, lard, lard-oil, and vegetable-oil, annotto, and other coloring matter, intestinal fat, and offal fat made in imitation or semblance of butter or when so made, calculated or intended to be sold as butter or for butter.

It is seen that the federal law does not recognize such 
trade terms as "butterine". All mixtures containing animal fats made in semblance of butter are legally known as oleomargarine. When coloring matter is added to butter fat, within the meaning of the law the product is regarded as butter; but when coloring matter is added to animal fats or vegetable oils the product is legally designated as oleomargarine.

Section 5 of the act requires that all manufacturers of oleomargarine shall keep books and render such returns of materials and products, and shall put up such signs as the Commissioner of Internal Revenue may direct. Sec. 6 also requires that all packages containing oleomargarine must be branded or marked as the Commissioner shall prescribe. In all these cases the word, oleomargarine, must be used to designate the product.

In addition to branding the product with the word, oleomargarine, the manufacturer is required in Sec. 7 , to affix securely on each package a label containing the following: "Notice.-The manufacturer of the oleomargarine herein contained has complied with all the requirements of law. Every person is cautioned not to use either this package again or the stamp thereon again, nor to remove the contents of this package without destroying said stamp under the penalty provided by law in such cases". The Treasury Department has placed this statement on form 219 which also contains the words "For Oleomargarine," together with the manufacturer's factory number, the collection district and the state in which his factory is located.

Sections I4 and I5 require the Internal Revenue Commissioner to employ a chemist who shall ascertain whether or not oleomargarine contains any ingredients that are deleterious to health. Appeal may be taken from the decisions of the Commissioner to a board com- 
posed of the Surgeon-General of the Army, the SurgeonGeneral of the Navy, and the Secretary of Agriculture. If it is found that any oleomargarine contains injurious ingredients it shall be forfeited to the United States. These two sections contain very important provisions, because they secure to the consumer a wholesome product. This law, in effect until I9n2, taxed all oleomargarine manufactured and consumed in the United States, at a flat rate of 2 cents per pound. Section 8 reads as follows:

That upon oleomargarine which shall be manufactured and sold, or removed for consumption or use, there shall be assessed and collected a tax of 2 cents per pound to be paid by the manufacturer thereof; and any fractional part of a pound in a package shall be taxed as a pound. The tax levied by this section shall be represented by coupon stamps; and the provisions of existing laws governing the engraving, issue, sale, accountability, effacement, and destruction of stamps relating to tobacco and snuff, as far as applicable are hereby made to apply to stamps provided for by this section.

On oleomargarine that is to be exported no tax is levied; but it must be inspected by agents of the government and must be marked with the word, oleomargarine.

All oleomargarine imported is to be taxed fifteen cents a pound in addition to any impost duty that may be imposed upon it.

Besides the tax of two cents per pound on oleomargarine produced for home consumption, the law imposes special annual taxes of six hundred dollars on the manufacturer, four hundred and eighty dollars on the wholesale dealer in oleomargarine, and forty-eight dollars on retailers.

As will be seen later some of these provisions have been amended in the law of May 9, 1902. 
THE CASE OF SCHOLLENBERGER $v$. PENNSYLVANIA.

As has been pointed out, the prohibitory principle of the oleomargarine law of Pennsylvania was tested in the case of Powell $v$. Pennsylvania and upheld by the highest tribunal of the land. The beginnings of the Powell case go back to July Io, I885, which was over a year before Congress enacted the federal oleomargarine law. The federal law, approved Aug. 2, I886, made an important change in the constitutional status of those state laws that completely prohibited the manufacture and sale of oleomargarine. This law required rigid inspection of the manufacturing process and provided for the production of a wholesome food product. In as much as the national government through the operation of this law recognizes oleomargarine as a wholesome product, the argument that the question of wholesomeness was still a matter for the state legislature to determine had now very little force. In the Powell case the question turned upon the fact as to whether or not the prohibitory law of Pennsylvania was in violation of the Fourteenth Amendment. The U.S. Supreme Court then declared that the Fourteenth Amendment was not designed to interfere with the exercise of the police power by the state for the protection of health, the prevention of fraud, and the preservation of public morals.

The constitutionality of the prohibitory principle was now to be tested in the case of Schollenberger $v$. Pennsylvania (I7I U. S. I) on different grounds. The fact that Congress provided for the regulation of the manufacture of oleomargarine and imposed an internal revenue tax on the product, caused the U. S. Supreme Court to hold that the federal law of I 886 recognizes oleomargarine as a lawful article of commerce. The validity of the Pennsylvania law in the Schollenberger case, therefore, 
turned on the question as to whether or not it was in conflict with the federal statute and with the constitutional clause that delegates the power to regulate commerce among the states, to the national Congress.

The facts in the Schollenberger case are as follows: The Oakdale Manufacturing Co. manufactured oleomargarine in Providence, R. I., and complied in every respect with the Act of Congress of Aug. 2, I886. The defendant in the case as agent of the Oakdale Co. was a wholesale dealer in Philadelphia and sold oleomargarine as such in its original package to James Anderson for his own personal use. The fact that the article was not butter but oleomargarine was made known to the purchaser. The lower court entered judgment in favor of the defendant. The Commonwealth appealed the case to the Supreme Court of the state where the judgment was reversed. The case was then brought before the U. S. Supreme Court on a writ of error.

The Commonwealth of Pennsylvania argued that oleomargarine is a newly discovered product. It is therefore not in the class of universally recognized articles of commerce. The state also argued that the question of wholesomeness and whether it is nondeceptive, are matters for the state legislature to decide; and that when the imported article is sold by the retailer to the consumer it is not in the original package within the protection of the interstate commerce provision of the constitution of the United States.

Mr. Justice Peckham wrote the opinion of the court. Mr. Justice Harlan, who wrote the opinion of the court in the case of Powell $v$. Pennsylvania, dissented.

The court held that the federal law of Aug. 2, I886, recognizes oleomargarine as a lawful article of commerce. 
Any legislation of Congress upon the subject must, of course, be regarded by this court as a fact of the first importance. .. By reference to the statutes we discover that Congress in I 886 passed "An Act defining butter, also imposing a tax upon and regulating the manufacture, sale, importation, and exportation of oleomargarine"....

This act shows that Congress at the time of its passage in I886 recognized the article as a proper subject of taxation and as one which was the subject of traffic and of exportation to foreign countries, and of importation from such countries. Its manufacture was recognized as a lawful pursuit, and taxation was levied upon the wholesale and retail dealers therein, and also upon the article itself.

As to the extent of the manufacture and its commercial nature, it is not improper to refer to the reports of the Secretary of the Treasury, which show that the tax receipts from its manufacture and sale in the United States under the act above mentioned, during the nine years beginning with 1887 , amounted to over ten million dollars....

Upon all these facts we think it apparent that oleomargarine has become a proper subject of commerce among the states and with foreign nations.

The court also held that as a pure article oleomargarine can be imported from one state into another and sold in the original package.

The general rule to be deduced from the decisions of this court is that a lawful article of commerce cannot be wholly excluded from importation into a state from another state where it was manufactured or grown. The state has power to regulate the introduction of any article, including a food product, so as to insure purity of the article imported, but such police power does not include the total exclusion even of an article of food.

In connection with the sale of oleomargarine in the 
original package the court refers to cases involving the interstate commerce clause. The case of Leisy $v$. Hardin, I35 U. S. I00, is cited. This is the famous liquor case in which the court denied the state the power to exclude articles of commerce recognized by Congress, as such, unless such power were granted by special permission of Congress. Reference is then made to the Wilson Act passed by Congress on Aug. 8, I890, which was subsequent to the Leisy decision. This law provided that liquor transported into any state or territory shall be subject to the laws of the state to the same extent as liquor manufactured within the state, and that it shall not be exempt by reason of being introduced into the state in the original package. "This was held to be a valid and constitutional exercise of the power conferred upon Congress. In re Rahrer, Petitioner, I40 U. S., 545. At the time this decision was pending there was no such legislation granting full power over oleomargarine in its original package, and in the absence of such legislation the importation into the state of a lawful article of commerce must continue until a sale in the original package is effected. The opinion of the court does not extend beyond the first sale.

The court also pointed out that the opinion in the Powell case which held the prohibitory law of Pennsylvania constitutional is not reversed by the decision in the Schollenberger case which declares the same law unconstitutional. The former case did not involve the commerce clause, but was decided on the question as to whether or not the conviction of the defendant was in violation of the Fourteenth Amendment.

Justices Gray and Harlan dissented from the opinion of the court. They held that, in spite of the fact that the Schollenberger case raised the question of conflict 
with the commerce clause, oleomargarine was considered by the state legislature questionable as to its wholesomeness; and that its appearance is so much like butter as to deceive a great many people and actually defraud them in causing them to buy a thing they do not want; and that the questions of danger to public health and the preventive measures necessary are questions of fact and public policy, the determination of which belongs to the legislative department and not to the judiciary; and that the complete prohibition of oleomargarine, even though it indirectly affected interstate commerce, was a proper exercise of the police power of the state.

The opinion of the court regarded oleomargarine as a wholesome product and viewed the case almost entirely in its relation to the interstate commerce clause. With the Leisy case as a precedent, it could not do otherwise but declare the prohibitory law of Pennsylvania unconstitutional. On the other hand, the dissenting opinion was more concerned with the social aspect of the case. Even though oleomargarine is wholesome, the dissenters believed that a wholesale fraud is perpetrated upon the people when the article is sold.

\section{RE-ENACTMENT OF THE RESTRICTIVE PRINCIPLE IN PENNSYLVANIA}

The Schollenberger case was decided May 23, 1898 . It did not take long for the Pennsylvania state legislature to enact a law that would be held valid. A restrictive law was passed on May 5, I899. ${ }^{1}$ The main provision of this law was the same, in principle, as the law in effect prior to I 885 . The office of the dairy and food commissioner had been established in I893. The law of 1899 allowed the manufacture and sale of oleomargarine free

${ }^{1}$ Laws of Pennsylvania, 1899, p. 241. 
from coloration, but prohibited the manufacture and sale of oleomargarine in imitation of yellow butter. The same idea was embodied in the law of May 29 , I90,${ }^{,}$and was passed upon by the Superior Court of the state in the cases of Commonwealth $v$. Clewell, 49 Pennsylvania Sup. Ct. 389, and Commonwealth v. Ignatavig, 49 Pennsylvania Sup. Ct. 397. In the Act approved June 5, $1913,{ }^{2}$ the tint or shade of yellow allowed in oleomargarine is specifically defined.

If the main provisions of the Pennsylvania law had to be made less stringent in 1899 , strength and vigor were added to the law by the enactment of other provisions. These required the payment of license fees, of \$10oo, $\$ 500, \$ 100$, and $\$ 50$, by the manufacturer, the wholesale dealer, the retailer, and the hotel and restaurant keepers, respectively. These fees are considerably higher than the special annual taxes required by the federal law. In addition to the license fees it was required that conspicuous signs be placed in places of business manufacturing or selling oleomargarine. Restaurants and boarding houses must also display signs. Wholesale and retail packages must be very plainly marked with the word, oleomargarine. James Faust, Dairy and Food Commissioner of Pennsylvania, states that the principle of licensing is a good one, because it locates the manufacturer and dealer and makes the administration of the law less difficult. He also believes that if the imitative color be kept out of oleomargarine, fraud will be eliminated and the price of oleomargarine will be less likely to approach that of butter. "The people who want butter, get it; and those who wish oleo, get it at a price relatively much.

${ }^{1}$ Laws of Pennsylvania, 1901, p. 327.

"Laws of Pennsylvania, I913, p. 412. 
lower than in the past; and, despite the color limit, they are buying it more generally than ever".

\section{THE FEDERAL ACT OF MAY 9, I9O2.}

The federal law of 1886 imposed a flat tax of two cents per pound on oleomargarine regardless of whether it was colored or uncolored. The dairy interests were not satisfied with this arrangement because it allowed oleomargarine to go on the market in a highly colored form and caused it to be bought as butter. They believed that if the oleomargarine interests could be compelled to market their product in its uncolored form, its shade of pale yellow would enable people to distinguish oleomargarine from pure butter. The dairy people also probably thought that easy recognition of oleomargarine would be enough to frighten the prospective purchaser from taking oleomargarine and that it would result in increasing the demand for butter. The way in which this was to be accomplished was to enact a federal law imposing a tax of ten cents per pound on colored oleomargarine and to leave the tax on uncolored oleomargarine at two cents. It was believed that the ten-cent tax was prohibitive and would put an end to yellow oleomargarine. These ideas were embodied in the Grout Bill. ${ }^{2}$ As in practically all other dairy legislation, the ten-cent tax idea was conceived and propagated by the dairy interests. It originated with the National Dairy Union and the question was agitated through the various state dairy associations whose members saw to it that the dairy farmers in the varions states wrote letters to their congressmen and senators asking them to support the bill. ${ }^{3}$

${ }^{1}$ Monthly Bulletin of the Dairy and Food Division of the Pennsylvania Department of Agricullure, August, 1914, p. Io.

${ }^{2} 56$ th Congress, Ist Session, H. R. 3717.

'Report of Aichigan Dairymen's Association for 1900, pp. 87-96. 
The important changes made in the oleomargarine law by the act of 1902 were the imposition of a ten-cent tax on colored oleomargarine and a tax of one-fourth of one cent on uncolored oleomargarine.

The act also provides that oleomargarine shall be subject to the laws of the states immediately upon its arrival within the limits of their territory to the same extent as that produced within the state, and that it shall not be exempt by reason of being introduced into the state in the original package.

Dealers who mix oleomargarine with butter are declared to be manufacturers of oleomargarine.

Wholesale dealers who sell only oleomargarine upon which the tax of one-fourth of one cent is imposed, are requires to pay a special tax of $\$ 200$ instead of $\$ 480$ as required in the law of 1886 . The special tax of retailers selling only the uncolored article is reduced from $\$ 48$ to $\$ 6$.

THE EFFECT OF OLEOMARGARINE LEGISLATION.

In the main, the oleomargarine legislation has been suppressive. The enactment of the state and federal laws and the rigorous administration of these laws by state dairy and food commissioners and by the U. S. Internal Revenue Commissioner, undoubtedly seriously hampered the rapid introduction of oleomargarine. In spite of this legislative restraint, however, as was shown in the chapter on prices, the fluctuations in the amount of oleomargarine consumed in the United States from I 887 to the present have been primarily caused by the rise and fall of the prices of butter, when butter prices were high more oleomargarine being consumed, and when they were low less being consumed.

The effect of the federal law of 1902, however, seems 
to have caused an important reduction in the production of oleomargarine as the following statement ${ }^{1}$ indicates:

\begin{tabular}{|c|c|c|c|c|c|}
\hline & & & $\begin{array}{l}\text { Total amount of } \\
\text { oleomargarine } \\
\text { (pounds) }\end{array}$ & $\begin{array}{l}\text { Amount of } \\
\text { colored } \\
\text { (pounds) }\end{array}$ & $\begin{array}{l}\text { Amount of } \\
\text { uncolored } \\
\text { (pounds) }\end{array}$ \\
\hline 1900. & - . & & $107,045,028$ & $\cdots \cdot \cdots$ & . . . . \\
\hline IgOI. . & . $\cdot$ & & . $104,943,856$ & $\cdots \cdots$ & . . . . \\
\hline 1902. & - & & . $126,316,427$ & $\ldots$ & $\cdots \cdots$ \\
\hline $1903 .$. & . & & . $73,285,946$ & $5,712,257$ & $67,573,689$ \\
\hline rgO4 . . & . $\cdot$ & - & $50,203,495$ & $3,785,670$ & $46,417,825$ \\
\hline 1910. & & - & . $14 \mathrm{r}, 862,280$ & $6, \mathrm{r} 76,99 \mathrm{I}$ & I $35,685,289$ \\
\hline 1914 . & . & - & . $144,021,276$ & $6,384,222$ & $137,637,054$ \\
\hline
\end{tabular}

This statement seems to indicate that the law of 1902 caused a great decrease in the amount of oleomargarine produced. It must not be forgotten, however, that 1903 and 1904 were years of comparatively low prices for butter, and that this fact helped to decrease the amount of oleomargarine produced. Beginning with I905 there was a general rise in the price of butter. This gave rise to a greater demand for oleomargarine and was sufficient cause to increase the production and consumption of the butter substitute. The imposition of a tax of ten cents in the law of I9O2 was of course an important factor. Its effect was to make it more profitable to produce uncolored oleomargarine; but this fact distinguished it from butter and had a tendency to lessen its demand. It made the production of colored oleomargarine very expensive, and some time had to elapse before ways and means could be devised by which the manufacturers and dealers could evade the new law without technically violating it. The law requires a tax of ten cents on olenmargarine artificially colored that makes it look like butter. Oleomargarine, however, can be colored by

'From Reports of U.S. Internal Revenue Commissioner. 
means of highly colored oils used as nutritive ingredients in the product. Such oils are peanut oil, soya-bean oil, soy-bean oil, mustard oil, ctc. ${ }^{x}$ These are sufficiently neutral and, as they are also nutritive, they can be used as regular ingredients. The real purpose of their use is of course to color the oleomargarine, in semblance of butter. Oleomargarine thus colored is not artificially colored within the meaning of the statute, and can not be taxed, therefore, at the rate of ten cents per pound, but must be taxed at one-fourth cent per pound. It is perhaps not erroneous to say that this evasion of the spirit of the law played an important rôle in increasing the production of oleomargarine.

The history of the manufacture and sale of oleomargarine since the passing of suppressive or regulative laws, dating back as far as 1877 , is full of evasions of the law. Behind these evasions the enterprising manufacturer is nearly always visible. He has plenty of capital at hand to engage the best legal talent in the country and to pay the fines of the dealer that gets into trouble with the state or federal authorities.

The census of I 900 gives the cost of materials in the manufacture of oleomargarine in the United States for that year at $\$ 7,639,501$, and the value of the product at $\$ 12,499,812$. Not taking capital costs into account, this shows a profit of over 50 per cent, which is of course enormous. This high profit is responsible for the insidious and persistent efforts of the oleomargarine interests to manufacture and sell their product.

The dealer, however, also frequently takes the initiative to adulterate or in various ways to defraud the public or evade the law. These methods are recorded in the

${ }^{1}$ Vide, Report of the U. S. Internal Revenue Commissioner for 1911 , p. 18. 
reports of the state dairy and food commissioners. Many are very clever and make interesting reading matter. One of the earliest and commonest frauds of which the dealer has been guilty, is the mixing of butter and oleomargarine in his own store. This evil called forth a provision in the law of 1902 declaring a dealer guilty of such an act to be a manufacturer of oleomargarine, and to be subject to the special tax of $\$ 600$. The Internal Revenue Commissioner as late as I9I I ${ }^{x}$ reports that dealers frequently buy the uncolored oleomargarine and then color it in their store. This is done by buying a tub of colored oleomargarine and paying the special tax of $\$ 48$ for dealing in colored oleomargarine. The dealer buys a lot of uncolored oleomargarine, colors this artificially, and puts it in the tub that still contains some of the colored oleomargarine that he bought from the manufacturer. This has been discovered by field officers, but its practice is very diffcult to prove. The Commissioner says that by this simple process the dealer "can add $93 / 4$ cents to every pound manipulated, and, by furnishing this to his customers when they call for butter, he is enabled to dispose of this product, which cost him from twelve to fifteen cents per pound, at anywhere from twenty-five to forty cents a pound. The comparative immunity from detection and punishment and the great financial profit growing out of the transaction have proved sufficient inducement to cause thousands of otherwise reputable grocers, market men, and dealers to engage in the nefarious business of defrauding the Government of its revenue and perpetrating a fraud on their customers. It is confidently believed that the oleomargarine law is, at this 
time, corrupting and debauching more taxpayers and affords the opportunity for greater fraud upon the public than any other statute with which the internal-revenue bureau has to deal." s

Violations of the law still continue, as may be seen by the Commissioner's statement: "A total of 2.704 violations of this law were reported during I9I4 as against I,745 for I9I3. These violations involved 2,327 persons -67 for violations as manufacturers, including the cases of illicit manufacture through the additional artificial coloration to the uncolored product, 89 wholesale dealers, and 2,I 7 r retail dealers." 2

The numerous frauds perpetrated in connection with the manufacture and sale of oleomargarine, the inability to say whether or not it was wholesome when it first appeared on the market, and the great agitation conducted by the dairy interests against oleomargarine, placed a stigma upon the product that it has not yet lived down. If the oleomargarine interests had been wise from the beginning, and had produced a wholesome product, had invited open inspection of their methods of manufacture, had plainly marked their product, had encouraged the dealers to sell it for what it is, and had widely advertised the product as oleomargarine, oleomargarine by now would not only have lost the stigma that at first attached to it, but it would have made a place for itself in the market second only to that of first class butter. Much of the money spent by the oleomargarine and dairy interests in agitating their sides of the question could have been more profitably used in their respective industries. Much of the time and money

${ }^{1}$ Op. cit., p. 18.

${ }^{2}$ Report of the U.S. Internal Revenue Commissioner for 1914, p. 21 . 
spent in legislating and prosecuting could also have been used to better advantage.

There seems to be a disposition now among the oleomargarine interests to follow at least partially the plan above outlined. In New York City there appears at numerous places the advertisement worded thus: "Oleomargarine, the great American spread for bread." A block of oleomargarine is shown and alongside a cow, beautiful and gentle in appearance, that is supposed to say: "You can thank me for the butter flavor." This is the attitude that the oleomargarine interests ought to have taken from the beginning. Instead of attempting to evade the law they should have complied with it. The law has been a serious hindrance to the kind of business policies to which they have adhered. In helping them to establish a reputation for the product, however, the federal law has been a great ally. This law puts its stamp of approval upon the method of manufacture and upon the wholesomeness of the product.

As a revenue measure the federal law is unsuccessful. The Internal Revenue Commissioner states that its administration entails great effort and expense. The following statement shows also that the total tax receipts from oleomargarine are small:

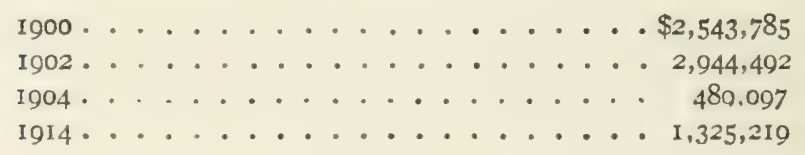

From I887 to 1902, the year the rate of tax was changed, the federal oleomargarine statute yielded a gradually increasing revenue. In 1902 it amounted to nearly three million dollars. After this year it decreased very materially, but beginning with 1905 it began to 
increase again and in I9I4 amounted to over a million dollars. The Internal Revenue Commissioner makes the following comment in connection with the revenue aspect of the oleomargarine law:

Had the tax on oleomargarine been two cents a pound during the past fiscal year instead of a nominal rate of ten cents and an actual rate of one-fourth cent a pound, the revenues would have been increased by $\$ 1,793,100$, a large sum expended in attempting to enforce the present statutes would have been saved, and the corruption of great numbers of American citizens, as well as fraud on the public not generally dreamed of, would have been prevented. ${ }^{1}$

\section{REVISION OF THE LAW NECESSARY}

The Internal Revenue Commissioner strongly urges a complete revision of the present federal law. ${ }^{2}$ The recommendations which he makes may be enumerated as follows: (I) That the double tax rate be abolished and that a flat rate in lieu thereof be adopted. (2) That the practice of handling oleomargarine in bulk or in large packages be prohibited. (3) That the manufacturers be required to pack oleomargarine in packages running from onehalf to five pounds. (4) That each and every package be sealed with a revenue stamp affixed. (5) That the product be sold only in original unbroken packages. (6) That heavy penalties be imposed for removal from factory in other than stamped packages. (7). That heavy penalties be impused for any dealer having in his possession or selling any oleomargarine not covered by proper stamps. (8) That heavy penalties be imposed for selling oleomargarine as butter.

${ }^{1}$ Report of Internal Revenue Commissioner for 1911, p. I9.

"Ibid. 
If these provisions were embodied in a statute, the oleomargarine law could be enforced and frauds would probably come to an end. Fraud enters so easily into the oleomargarine trade that the most perfect administrative system must be devised to eliminate it. The oleomargarine interests would have no reason to complain at the severity of the above provisions. They would do well rather to encourage their enactment. see to it that their product is as good as it can be made, and keep it separate and distinct from butter. As long as the standard of living permits the use of butter the American people are not willing to have the dairy industry jeopardized by the insidious oleomargarine product which, if allowed free course, would flood the market with a spurious article and gradually destroy the butter industry. Good butter is unquestionably a better and more desirable article of food than the best oleomargarine. The food value of the two products is nearly the same, but the aroma and flavor of butter are superior to that of oleomargarine. This is a fact of considerable importance. While we must eat to live, we should be allowed, in some small measure at least, to live to eat. 




\section{University of Toronto Library}

DO NOT

REMOVE

THE

CARD

FROM

THIS

POCKET

Acme Library Card Pocket LOWE-MARTIN CO. LIMTTED 
47) 